BIANCA CAETANO DE ALMEIDA

\title{
DIVERSIDADE DE BACTÉRIAS EM AMOSTRAS DE ÁGUA DO MAR NO CANAL DE SÃO SEBASTIÃO
}

Tese apresentada ao Instituto de Ciências Biomédicas da Universidade de São Paulo, para obtenção do título de Doutora em Ciências (Microbiologia). 


\section{DIVERSIDADE DE BACTÉRIAS EM AMOSTRAS DE ÁGUA DO MAR NO CANAL DE SÃO SEBASTIÃO}

Tese apresentada ao Instituto de Ciências Biomédicas da Universidade de São Paulo, para obtenção do título de Doutora em Ciências.

Área de Concentração: Microbiologia

Orientadora: Profa. Dra. Irma N. G. Rivera 
DADOS DE CATALOGAÇÃO NA PUBLICAÇÃO (CIP)

Serviço de Biblioteca e Informação Biomédica do

Instituto de Ciências Biomédicas da Universidade de São Paulo

(C) reprodução total

Almeida, Bianca Caetano de.

Diversidade de bactérias em amostras de água do mar no Canal de São Sebastião / Bianca Caetano de Almeida. -- São Paulo, 2009.

Orientador: Irma Nelly Gutierrez Rivera.

Tese (Doutorado) - Universidade de São Paulo. Instituto de Ciências Biomédicas. Departamento de Microbiologia. Área de concentração: Microbiologia. Linha de pesquisa: Ecologia microbiana.

Versão do título para o inglês: Diversity of bacteria in seawater samples at São Sebastião Channel.

Descritores: 1. Biodiversidade marinha 2.

Proteobactéria 3. Hibridização in situ fluorescente 4.16S rRNA (Sequenciamento) 5. Biblioteca de clones I. Rivera, Irma Nelly Gutierrez II. Universidade de São Paulo. Instituto de Ciências Biomédicas. Programa de PósGraduação em Microbiologia III. Título. 
Candidato(a): $\quad$ Bianca Caetano de Almeida.

Título da Tese: $\quad$ Diversidade de bactérias em amostras de água do mar no Canal de São Sebastião.

Orientador(a): Irma Nelly Gutierrez Rivera.

A Comissão Julgadora dos trabalhos de Defesa da Tese de Doutorado, em sessão pública realizada a .................., considerou

\section{( ) Aprovado(a) ( ) Reprovado(a)}

$\begin{array}{ll}\text { Examinador(a): } & \begin{array}{l}\text { Assinatura: } \\ \text { Nome: } \\ \text { Instituição: }\end{array} \\ \text { Examinador(a): } & \begin{array}{l}\text { Assinatura: } \\ \text { Nome: } \\ \text { Instituição: }\end{array} \\ \text { Examinador(a): } & \begin{array}{l}\text { Assinatura: } \\ \text { Nome: }\end{array} \\ \text { Instituição: } & \begin{array}{l}\text { Assinatura: } \\ \text { Nome: } \\ \text { Instituição: }\end{array} \\ \text { Assinatura: } & \text { Nome: } \\ \text { Instituição: } & \end{array}$ 


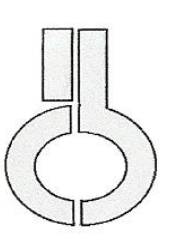

\section{CERTIFICADO DE ISENÇ̃̃O}

Certificamos que o Protocolo CEP-ICB $\mathrm{N}^{\circ}$ 096, referente ao projeto intitulado "Diversidade de microrganismos isolados de água do mar no canal de São Sebastião, litoral norte do estado de São Paulo " sob a responsabilidade de Bianca Caetano de Almeida, foi analisado na presente data pela CEEA - COMISSÃO DE ÉTICA EM EXPERIMENTAÇÃO ANIMAL e pela CEPSH - COMISSÃo DE ÉTICA EM PESQUISA COM SERES HUMANOS, tendo sido deliberado que o referido projeto não envolve manipulação animal ou humana que justifique uma aprovação quanto aos princípios éticos exigidos por ambas as Comissões.

São Paulo, 25 de abril de 2005.

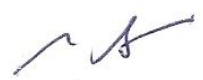

Profa. Dra. MARÍLIA C.L.SEELAENDER Coordenadora da CEEA - ICB/USP

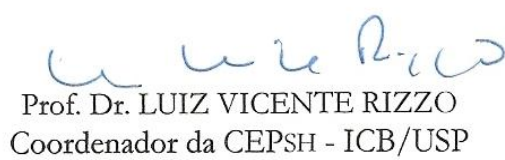


Dedico este trabalho ao meu anjo da guarda, meu irmão Felippe, pela força que me envia de onde quer que esteja. 


\title{
AGRADECIMENTOS ESPECIAIS
}

\author{
Aos meus pais, \\ pela educação, amor, \\ carinho, apoio, confiança, \\ investimento e constante incentivo.
}

\author{
À minha irmã, \\ pela paciência, apoio, \\ companheirismo e por dividir \\ comigo todos os momentos da vida.
}

\author{
Aos meus avós, \\ pelos ensinamentos, orações, \\ torcida e orgulho por uma neta doutora.
}

\author{
Ao Rodrigo, \\ por todo o amor, atenção, \\ dedicação, paciência, por estar \\ ao meu lado em todos os momentos e \\ por acreditar e vibrar comigo a cada conquista.
}




\section{AGRADECIMENTOS}

À prof ${ }^{a}$. Dra . Irma N. G. Rivera pela orientação, ensinamento, apoio, amizade durante os anos de convivência e por confiar este trabalho a mim. Essa confiança contribuiu para meu amadurecimento profissional e pessoal.

Às pessoas que acreditaram e torceram por mim: meus familiares (não vou citar nomes, pois são muitos), família D’Amico e família Froelich que me acolheram com muito carinho. Obrigada pela torcida!

Aos meus amigos de Itapeva que vibraram a cada etapa conquistada e torceram para que eu conseguisse chegar até aqui. Valeu!

Aos meus grandes amigos e colegas do laboratório de Microbiologia Ambiental: Claudiana, Mariela, Gislaine, Lílian, Mário, Zé Edu e Franklin não só pela ajuda no desenvolvimento desse trabalho, mas também pelo carinho, companheirismo, convívio diário, troca de informações e ensinamentos tanto profissionais quanto pessoais. Obrigada por me entenderem, principalmente nas horas de estresse!

Aos amigos e colegas que já passaram pelo laboratório de Microbiologia Ambiental e que hoje são doutores: Priscilla Ueno, Keili Souza, Caroline Markman, Solange Lessa e Oyama Rodrigues por toda ajuda e paciência no início do trabalho.

Aos colegas dos laboratórios do grupo de Microbiologia Ambiental e de outros laboratórios do ICB: Sandra, Ana Carolina, Rubens, Cristina Nakayama, Maria do Carmo, Patrícia Ramos, Eriques, Ronaldo Biondo, Diogo Marquezoni. Um agradecimento especial à Ema Kunh, Cristine Barreto e Roberta Almeida pelos ensinamentos e esclarecimentos, principalmente, na etapa final desse trabalho.

Aos estagiários que passaram pelo laboratório: Renata, Bruna, Neilza, Milena, Mariana, Roberta, Helena, Daniel, Lívia, Maurícia, Natália e André que de uma forma ou de outra contribuíram com esse trabalho. 
À amiga Bióloga Zelma Fernandes Marinho, minha "mãe" paulistana, por todo seu carinho, ajuda em todos os momentos e por fazer com que as horas de trabalho se tornassem mais divertidas.

À Química Rosa Gamba e ao Sr. Luís pela ajuda, assistência técnica, ensinamentos, convivência e amizade.

Aos profs. Drs. Vivian Helena Pellizari, René Peter Schneider, Claudete Rodrigues de Paula, Carlos Frederico Martins Menck, Márcia Pinto Alves Mayer, Ana Clara Guerrini Schenberg por permitirem o uso dos laboratórios e dos aparelhos.

Aos profs. Drs. Fabiano Lopes Thompson, Paulo César Abreu, Juliana Calábria de Araújo, Cristine Chaves Barreto e Patrícia Locosque Ramos pelas valiosas sugestões na avaliação do trabalho de qualificação.

Aos funcionários do Departamento de Microbiologia do Instituto de Ciências Biomédicas, especialmente às secretárias Alice, Naíde e Aninha pela colaboração e auxílio.

Ao Dr. John P. van der Meer, do PAMBA (Pan American Marine Biotechnology Association) por toda sua gentileza, atenção e colaboração prestada na edição de trabalhos em inglês.

Aos funcionários do CEBIMar - USP (Centro de Biologia Marinha - USP) pelo apoio durante as coletas de amostras.

À Universidade de São Paulo e ao Instituto de Ciências Biomédicas, sem os quais esse trabalho não poderia ter sido desenvolvido.

À CAPES pela concessão da bolsa do programa PAE (Programa de Aperfeiçoamento ao Ensino).

À FAPESP pela concessão da bolsa de doutorado.

Obrigada a todos por acreditarem nesta e nas futuras conquistas que farei! 
"Ao se caminhar para um objetivo, sobretudo um grande e distante objetivo, as menores coisas se tornam fundamentais. Uma hora perdida é uma hora perdida e, quando não se tem um rumo definido é muito fácil perder horas, dias ou anos, sem se dar conta disso."

Amyr Klink (Cem dias entre céu e mar) 


\section{RESUMO}

ALMEIDA, B.C. Diversidade de bactérias em amostras de água do mar no Canal de São Sebastião. 2009. 198 f. Tese (Doutorado em Microbiologia) - Instituto de Ciências Biomédicas, Universidade de São Paulo, São Paulo, 2009.

O ambiente marinho é caracterizado por possuir parâmetros típicos, como alta pressão, salinidade, temperatura, ausência de luz, entre outros e por possuir uma enorme diversidade de microrganismos. Estudar a diversidade bacteriana marinha é de suma importância para compreender a estrutura e o padrão de distribuição dessa comunidade. A diversidade bacteriana marinha pode ser melhor estudada, combinando técnicas convencionais e técnicas que empreguem tecnologias modernas para sua melhor compreensão. Verificar a concentração de bactérias heterotróficas viáveis e de comunidades bacterianas totais na água do mar do Canal de São Sebastião, assim como identificá-las foram os objetivos deste estudo. Durante 20 meses consecutivos (agosto/2005 a março/2007) as bactérias marinhas viáveis foram quantificadas e isoladas, de dois pontos distintos do Canal de São Sebastião, empregando a contagem em placas e o meio ágar marinho. Nas 40 amostras de água do mar coletadas foi verificada uma concentração de bactérias marinhas variando de $2,0 \times 10^{1}$ a 3,4 x $10^{3} \mathrm{UFC} / \mathrm{mL}$, das quais foram obtidos 295 isolados bacterianos. A caracterização e triagem desses isolados foi feita através da coloração de Gram e técnicas genotípicas como BOX-PCR e ERIC-PCR. O enfoque da triagem era selecionar apenas as bactérias gram-negativas para identificá-las dentro do Filo Proteobacteria. Após triagem, a identificação molecular de 168 bactérias marinhas foi feita através do seqüenciamento parcial da região $16 \mathrm{~S}$ rRNA. O seqüenciamento permitiu observar que $86,9 \%$ das bactérias marinhas pertenciam ao gênero Vibrio, enquanto que as demais bactérias pertenceram aos gêneros Photobacterium, Pseudomonas, Aeromonas, Alteromonas, Pseudoalteromonas, Shewanella, Alcaligenes, Yangia, Paracoccus e Thalassobius. A concentração das comunidades bacterianas foi verificada através da técnica "FISH" utilizando sondas para as classes Alpha-, Beta-, Gammae Deltaproteobacteria e permitiu observar as freqüências de $9,5 \%, 10,2 \%, 8,1 \%$ e $6,8 \%$, respectivamente, em relação ao número de células totais coradas com DAPI que variou de 7,0 x $10^{6}$ a $2,3 \times 10^{7}$ céls $/ \mathrm{mL}$. Apesar da Betaproteobacteria ter apresentado a maior frequiência, os valores entre as classes Alpha-, Beta- e Gammaproteobacteria não foram estatisticamente diferentes. A comunidade total foi identificada através da construção de três bibliotecas de clones do gene 16S rDNA, onde a biblioteca 1 (Novembro/2006) foi composta por 96 clones, a biblioteca 2 (Fevereiro/2006) composta por 93 clones e a biblioteca 3 (Fevereiro/2007) composta por 94 clones. A diversidade nas amostras de água de mar foi definida em termos de filotipos ou unidades taxonômicas operacinais (UTOs) e os clones das três bibliotecas foram identificados como membros dos filos Proteobacteria, Bacteroidetes, Cyanobacteria, Firmicutes, Fusobacteria, Verrucomicrobia e Chloroflexi. A diversidade e a abundância foram determinadas usando os índices de Chao1, ACE e Shannon e o número de clones seqüenciados não foi suficiente para representar a riqueza bacteriana do Canal de São Sebastião.

Palavras-chave: Biodiversidade marinha. Proteobactérias. Hibridização in situ fluorescente. 16S-rRNA. Seqüenciamento. Biblioteca de clones. 


\begin{abstract}
ALMEIDA, B.C. Bacterial diversity in seawater samples at São Sebastião Channel. 2009. 198 f. Ph.D. Thesis (Microbiology) - Instituto de Ciências Biomédicas, Universidade de São Paulo, São Paulo, 2009.

The marine environment is characterized by typical ecological setting, as high pressure, salinity, temperature, light, and others and by sustains a vast bacterial diversity. The study of seawater bacterial diversity is so much important to understand the structure and the patterns distribution of the communities and this could be done combining conventional and contemporary methodologies. Determine the concentration of viable heterotrophic bacteria, total bacterial communities, and the bacterial identification were the objectives of this study. During 20 consecutive months (August 2005 to March 2007) marine viable bacteria were counting and isolated from two points of collection at São Sebastião Channel using plate count and marine agar. The concentration of marine viable bacteria varied from $2.0 \times 10^{1}$ to $3.4 \times 10^{3} \mathrm{CFU} / \mathrm{mL}$ in 40 seawater samples collected and 295 isolates were obtained. Preliminary viable bacterial characterization was done using Gram staining and only the Phylum Proteobacteria was identified by $16 \mathrm{~S}$ rRNA partial sequencing. The molecular genotyping was done by BOX-PCR e ERIC-PCR. One hundred and sixty eight marine viable bacteria were sequenced and $86.9 \%$ of them belonging to Vibrio genus, however the other were homologous with Photobacterium, Pseudomonas, Aeromonas, Alteromonas, Pseudoalteromonas, Shewanella, Alcaligenes, Yangia, Paracoccus and Thalassobius genus. The concentration of proteobacteria communities was verified using the fluorescence in situ hybridization (FISH) methodology for the Alpha-, Beta-, Gamma- and Deltaproteobacteria classes and the frequencies were $9.5 \%, 10.2 \%, 8.1 \%$ e $6.8 \%$, respectively when related to total cells count using DAPI staining that varied from $7.0 \times 10^{6}$ to $2.3 \times 10^{7}$ cells $/ \mathrm{mL}$. Although the Betaproteobacteria showed high frequency, the values between the Alpha-, Beta- and Gammaproteobacteria classes were not different statistically. The total community was identified by construction of three bacterial libraries of $16 \mathrm{~S}$ rDNA gene clones. The library 1, corresponding to seawater sample collected in November 2006 was compound by 98 clones. The Library 2, month February 2006 included 93 clones and the library 3, February 2007, was represented by 94 clones. The diversity was defined in terms of phylotypes or operational taxonomic units (OTUs). The phyla Proteobacteria, Bacteroidetes, Cyanobacteria, Firmicutes, Fusobacteria, Verrucomicrobia and Chloroflexi were identified in the three libraries of seawater samples. The diversity indices and richness were determined using Chao1, ACE and Shannon index, however, the clones number sequenced were not enough to determine the bacterial richness at São Sebastião Channel.
\end{abstract}

Keywords: Marine biodiversity. Proteobacteria. Fluorescent in situ hybridization. 16S-rRNA. Sequencing. Clone libraries. 


\section{LISTA DE FIGURAS}

Figura 1 - Árvore filogenética universal baseada nas sequências de 16S rRNA, mostrando 64 sequências de rRNA de todos os domínios filogenéticos conhecidos

Figura 2 - Árvore filogenética simplificada do Filo Proteobacteria baseada na sequiência do gene 16S rDNA mostrando os gêneros que fazem parte das classes das proteobactérias. A largura dos triângulos é proporcional ao número de gêneros dentro de cada cluster.

Figura 3 - Passos básicos da hidridização in situ fluorescente. As amostras são fixadas e as sondas de oligonucleotídeos marcadas são adicionadas permitindo a hibridização intracelular. O excesso de sonda é retirado e a amostra está pronta para ser identificada e quantificada em microscópio de epifluorescência ou citômetro de fluxo

Figura 4 - Esquema da estrutura e indicação das subunidades e macromoléculas do ribossomo bacteriano.

Figura 5 - Estrutura secundária do $16 \mathrm{~S}$ rRNA. A extremidade 5' é simbolizada por um ponto e a 3' por uma seta. As regiões relativamente conservadas são apresentadas em negrito; as regiões variáveis, em linhas finas (V1-V9, sendo que a V4 é exclusiva de eucariotos); as regiões pontilhadas são as que estão presentes em número limitado de estrutura

Figura 6 - Localização dos pontos de coleta no Canal de São Sebastião.

Figura 7 - Fluxograma mostrando as etapas de trabalho e esquematização de como os resultados serão apresentados no decorrer deste estudo

Figura 8 - Cálculo da concentração bacteriana total e dos grupos $\alpha$-, $\beta$-, $\gamma$ - e $\delta$-proteobacteria. A: 490,6 $\mathrm{mm}^{2}$; a: $0,0283 \mathrm{~mm}^{2} ; \mathbf{n}: \mathrm{N}_{\mathrm{t}}$ (número total de células contadas) $/ \mathrm{N}_{\mathrm{c}}$ (número total de campos contados); D: diâmetro da membrana; d: diâmetro do campo de visão

Figura 9 - Figura esquemática do plasmídeo $p G E M ®-T$ Easy e do múltiplo sítio de clonagem. Amp $^{\mathbf{r}}$ : gene de resistência a ampicilina; ori: origem de replicação; T7: sítio de início de 
transcrição da T7 RNA polimerase; SP6: sítio de início de transcrição da SP6 RNA polimerase. Figura extraída do catálogo do produto

Figura 10 - Variação dos valores dos parâmetros físico-químicos medidos no Canal de São Sebastião. T. mar $\left({ }^{\circ} \mathbf{C}\right)$ : temperatura da água do mar; Sal (ppm): salinidade; Cond. $(\mathbf{m S})$ : condutividade; OD: oxigênio dissolvido; T. dia $\left({ }^{\circ} \mathbf{C}\right)$ : temperatura do dia (média dos valores mínimos e máximos)

Figura 11 - Variação da concentração de Bactérias Marinhas Viáveis (BMV) em amostras de água do Canal de São Sebastião por ponto de coleta

Figura 12 - Boxplot mostrando os valores da mediana e percentis 25 e 75 das contagens de Bactérias Marinhas Viáveis por ponto de coleta. Nota: Para efeito de visualização, as contagens de Bactérias Marinhas Viáveis estão apresentadas em UFC/100 mL .72

Figura 13 - Média da variação de Bactérias Marinhas Viáveis (BMV), Coliformes Termotolerantes (CT) e Enterococos Intestinais (EI) nas amostras de água do mar durante o período de coleta no Canal de São Sebastião. Nota: Para efeito de visualização, as contagens dos três indicadores estão apresentadas em UFC/100 mL

Figura 14 - Fotografia de gel de agarose 1\% em tampão TAE 1X exemplificando a amplificação de bactérias marinhas pela técnica de BOX-PCR. Colunas 1 e 12: marcador de peso molecular Lambda DNA/Hind III - Promega; Colunas 2 - 11: perfis de bactérias marinhas.

Figura 15 - Fotografia de gel de agarose 1\% em tampão TAE $1 \mathrm{X}$ exemplificando a amplificação de bactérias marinhas pela técnica de ERIC-PCR. Colunas 1 e 12: marcador de peso molecular Lambda DNA/Hind III - Promega; Colunas 2 - 11: perfis de bactérias marinhas. .75

Figura 16 - Dendrograma construído pelo programa BioNumerics para a técnica de BOXPCR, usando o coeficiente de Dice, com as bactérias marinhas. .78 
Figura 17 - Dendrograma construído pelo programa BioNumerics para a técnica de ERICPCR, usando o coeficiente de Dice, com as bactérias marinhas.

Figura 18 - Árvore filogenética com as 18 sequiências que representam os isolados de bactérias marinhas, juntamente com as seqüências de linhagem tipo e/ou seqüências referências. A seqüência Methanocaldococcus jannaschii foi utilizada como grupo externo para enraizamento da árvore. Somente os valores de bootstrap que estavam acima de 50 foram mostrados. BMV...-SS: representantes das bactérias marinhas viáveis do Canal de São Sebastião; ( ): número de sequiências com identidade $\geq 97 \%$.

Figura 19 - Distribuição dos 168 isolados dentro da classe Proteobacteria. .90

Figura 20 - Freqüência dos 11 gêneros identificados pelo seqüenciamento parcial da região 16S de bactérias marinhas em amostras de água do mar coletadas no Canal de São Sebastião. .91

Figura 21 - Distribuição mensal dos gêneros identificados pelo seqüenciamento parcial da região $16 \mathrm{~S}$ de bactérias marinhas em amostras de água do mar coletadas no Canal de São Sebastião. Nota: Os números dentro de cada barra referem-se ao número de bactérias marinhas seqüenciadas

Figura 22 - Frequiência mensal dos gêneros identificados pelo seqüenciamento parcial da região $16 \mathrm{~S}$ de bactérias marinhas em amostras de água do mar coletadas no Canal de São Sebastião.

Figura 23 - Dendrograma construído pelo programa BioNumerics para a técnica de BOXPCR, usando o coeficiente de Dice, com as bactérias marinhas identificadas pelo sequenciamento parcial da região $16 \mathrm{~S}$ rRNA .95

Figura 24 - Dendrograma construído pelo programa BioNumerics para a técnica de ERICPCR, usando o coeficiente de Dice, com as bactérias marinhas identificadas pelo seqüenciamento parcial da região $16 \mathrm{~S}$ rRNA. 100 
Figura 25 - Variação da concentração de células bacterianas totais (DAPI) e dos grupos bacterianos $\alpha$-, $\beta$-, $\gamma$ - e $\delta$-proteobacteria nas amostras de água do mar coletadas no ponto 1 no Canal de São Sebastião.

Figura 26 - Variação da concentração de células bacterianas totais (DAPI) e dos grupos bacterianos $\alpha$-, $\beta$-, $\gamma$ - e $\delta$-proteobacteria nas amostras de água do mar coletadas no ponto 2 no Canal de São Sebastião 103

Figura 27 - Boxplot mostrando os valores da mediana e percentis 25 e 75 das concentrações de células totais e dos grupos bacterianos $\alpha$-, $\beta$-, $\gamma$ - e $\delta$ - proteobacteria por ponto de coleta. Nota: Para efeito de visualização, as concentrações bacterianas estão apresentadas em células/100 mL 105

Figura 28 - Freqüência de células hibridizadas com as sondas fluorescentes para os grupos $\alpha$ , $\beta$-, $\gamma$ - e $\delta$-proteobacteria, em relação ao total de células coradas com DAPI ao longo dos 20 meses de amostragem. Nota: As porcentagens mostradas equivalem à média dos pontos $1 \mathrm{e}$ 2

Figura 29 - Concentração de células hibridizadas com as sondas fluorescentes para os grupos $\alpha$-, $\beta$-, $\gamma$ - e $\delta$-proteobacteria ao longo dos 20 meses de amostragem. Nota: Os valores de contagens mostrados equivalem à média dos pontos 1 e 2 107

Figura 30 - Box-plot mostrando os valores de mediana e percentis 25 e 75 das contagens de células hibridizadas com as sondas fluorescentes para os grupos $\alpha$-, $\beta$-, $\gamma$ - e $\delta$-proteobacteria ao longo dos 20 meses de amostragem. Nota: Os valores de contagens mostrados equivalem à média dos pontos 1 e 2 . 109

Figura 31 - Árvore filogenética construída com as 28 seqüências forward representantes dos clones da biblioteca 1 e sequências referência. A seqüência Methanocaldococcus jannaschii foi utilizada como grupo externo para enraizamento da árvore. Somente os valores de bootstrap que estavam acima de 50 foram mostrados. BMV-...: clones representantes cada OTU; ( ): número de seqüências de clones com identidade de 97\%. Classificação filogenética: Filo (*), Classe (**) 120 
Figura 32 - Árvore filogenética construída com as 28 seqüências forward representantes dos clones da biblioteca 2 e sequências referência. A seqüência Methanocaldococcus jannaschii foi utilizada como grupo externo para enraizamento da árvore. Somente os valores de bootstrap que estavam acima de 50 foram mostrados. BMV-...: clones representantes cada OTU; ( ): número de seqüências de clones com identidade de 97\%. Classificação filogenética: Filo (*), Classe (**)

Figura 33 - Árvore filogenética construída com as 19 seqüências forward representantes dos clones da biblioteca 3 e seqüências referência. A seqüência Methanocaldococcus jannaschii foi utilizada como grupo externo para enraizamento da árvore. Somente os valores de bootstrap que estavam acima de 50 foram mostrados. BMV-...: clones representantes cada OTU; ( ): número de seqüências de clones com identidade de 97\%. Classificação filogenética: Filo (*), Classe $(* *)$ 122

Figura 34 - Freqüência dos filos bacterianos identificados pelo seqüenciamento parcial do gene 16S rDNA dos clones das bibliotecas. A: biblioteca 1 (novembro/2006); B: biblioteca 2 (fevereiro/2006); C: biblioteca 3 (fevereiro/2007). As seqüências foram identificadas através do Classifier no RDP utilizando o limite de confiança de $80 \%$. Nota: Os gráficos foram construídos com os resultados das sequências forward e reverse.

Figura 35 - Distribuição dos filos bacterianos em cada biblioteca. O tamanho dos círculos é proporcional ao número de clones em cada biblioteca, os quais estão mostrados entre parênteses. B1: biblioteca 1 (novembro/2006); B2: biblioteca 2 (fevereiro/2006); B3: biblioteca 3 (fevereiro/2007). Nota: Os resultados equivalem as sequências forward e reverse.

Figura 36 - Freqüência das classes bacterianas identificadas pelo seqüenciamento parcial do gene 16S rDNA dos clones das três bibliotecas de água do mar do Canal de São Sebastião. As seqüências foram identificadas através do Classifier no RDP utilizando o limite de confiança de $80 \%$

Figura 37 - Análise de rarefação dos clones constituídos pelas seqüências forward das bibliotecas construídas a partir do DNA de amostras de água do mar do Canal de São 
Sebastião em vários níveis de similaridade taxonômica. As análises são baseadas em seqüências parciais do gene $16 \mathrm{~S}$ rDNA. A: curva de rarefação da biblioteca 1 (novembro/2006); B: curva de rarefação da biblioteca 2 (fevereiro/2006); C: curva de rarefação da biblioteca 3 (fevereiro/2007); D: curva de rarefação das três bibliotecas. O intervalo de confiança foi de $95 \%$

Figura 38 - Análise de rarefação dos clones constituídos pelas seqüências reverse das bibliotecas construídas a partir do DNA de amostras de água do mar do Canal de São Sebastião em vários níveis de similaridade taxonômica. As análises são baseadas em seqüências parciais do gene $16 \mathrm{~S}$ rDNA. A: curva de rarefação da biblioteca 1 (novembro/2006); B: curva de rarefação da biblioteca 2 (fevereiro/2006); C: curva de rarefação da biblioteca 3 (fevereiro/2007); D: curva de rarefação das três bibliotecas. O intervalo de confiança foi de $95 \%$.

Figura 39 - Análise de rarefação dos clones constituídos pelas seqüências forward das três bibliotecas construídas a partir do DNA de amostras de água do mar do Canal de São Sebastião em cada nível de similaridade taxonômica. As análises são baseadas em sequiências parciais do gene 16S rDNA. A: nível de similaridade (100\%); B: nível de similaridade (97\%); C: nível de similaridade (95\%); D: nível de similaridade (80\%). O intervalo de confiança foi de $95 \%$

Figura 40 - Análise de rarefação dos clones constituídos pelas sequiências reverse das três bibliotecas construídas a partir do DNA de amostras de água do mar do Canal de São Sebastião em cada nível de similaridade taxonômica. As análises são baseadas em sequiências parciais do gene 16S rDNA. A: nível de similaridade (100\%); B: nível de similaridade (97\%); C: nível de similaridade (95\%); D: nível de similaridade (80\%). O intervalo de confiança foi de $95 \%$

Figura 41 - Número de OTUs estimadas para cada biblioteca para as diferentes distâncias evolutivas em amostra de água do mar do Canal de São Sebastião. A: estimativa para as três bibliotecas (seqüências forward) utilizando o estimador Chao1; B: estimativa para as três bibliotecas (seqüências forward) utilizando o estimador ACE; C: estimativa para as três bibliotecas (seqüências reverse) utilizando o estimador Chao1; D: estimativa para as três bibliotecas (sequiências reverse) utilizando o estimador ACE. O intervalo de confiança foi de $95 \%$ 


\section{LISTA DE TABELAS}

Tabela 1 - Ocorrência dos maiores grupos fenotípicos entre as cinco classes das Proteobactérias

Tabela 2 - Sondas utilizadas para a contagem de grupos bacterianos usando a técnica de hibridização in situ fluorescente (FISH) .58

Tabela 3 - Representantes dominantes das bactérias marinhas encontradas nas amostras de água do mar coletadas no Canal de São Sebastião.

Tabela 4 - Percentual de $\alpha$-, $\beta$-, $\gamma$ - e $\delta$-proteobacteria detectadas pela técnica de FISH em comparação às células totais detectadas por DAPI em amostras de água do mar coletadas no Canal de São Sebastião 108

Tabela 5 - Relação do número de clones obtidos e seqüenciados em cada biblioteca. 112

Tabela 6 - Número de OTUs observadas em cada biblioteca, a partir do cutoff de distâncias definidas pelo programa DOTUR 113

Tabela 7 - Representantes dominantes dos clones bacterianos da biblioteca 1 encontrados nas amostras de água do mar coletadas no Canal de São Sebastião no mês de novembro/2006.

Tabela 8 - Representantes dominantes dos clones bacterianos da biblioteca 2 encontrados nas amostras de água do mar coletadas no Canal de São Sebastião no mês fevereiro/2006 116

Tabela 9 - Representantes dominantes dos clones bacterianos da biblioteca 3 encontrados nas amostras de água do mar coletadas no Canal de São Sebastião no mês de fevereiro/2007

Tabela 10 - Índices de diversidade e riqueza obtidos a partir da análise das sequiências parciais do gene $16 \mathrm{~S}$ rDNA dos clones das três bibliotecas de amostras de água do mar do Canal de São Sebastião. 


\section{SUMÁRIO}

1 INTRODUÇÃÕ

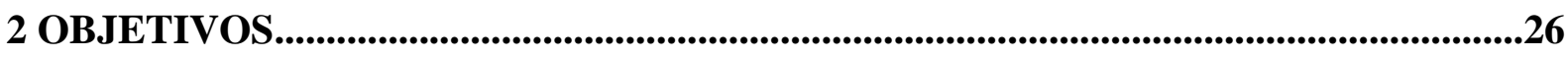

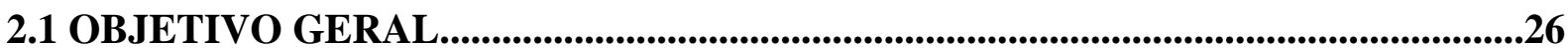

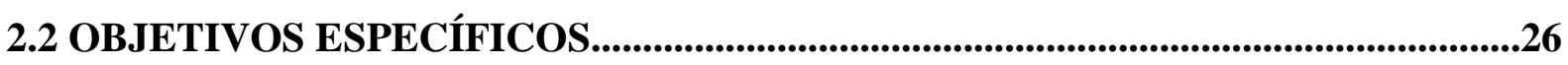

3 REVISÃO BIBLIOGRÁFICA.................................................................................................27

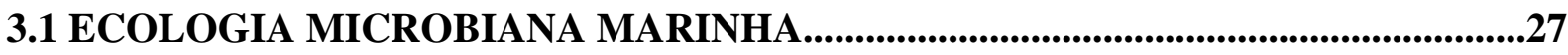

3.2 DEFININDO ESPÉCIES PROCARIÓTICAS ...............................................................29

3.3 DIVERSIDADE BACTERIANA MARINHA.........................................................32

3.4 PROTEOBACTÉRIAS..................................................................................34

3.4.1 Alphaproteobacteria ...................................................................................................................36

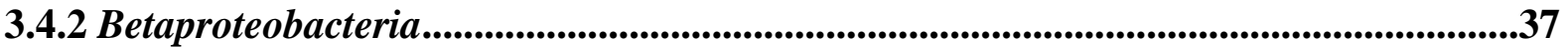

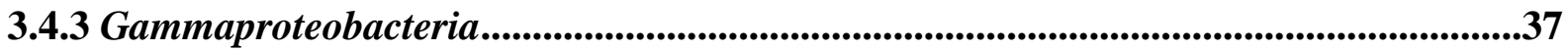

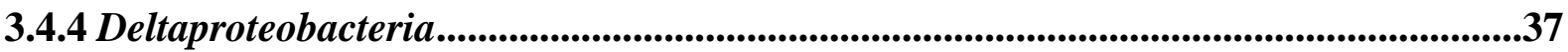

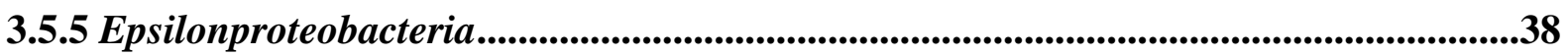

3.5 MÉTODOS DE ESTUDO DAS COMUNIDADES BACTERIANAS..........................38

3.5.1 Isolamento e cultivo de bactérias.......................................................................38

3.5.2 Identificação direta de comunidades bacterianas...........................................................40

3.5.3 Análise molecular de comunidades bacterianas........................................................43

3.5.3.1 Tipagem molecular de bactérias viáveis por rep-PCR.................................................44

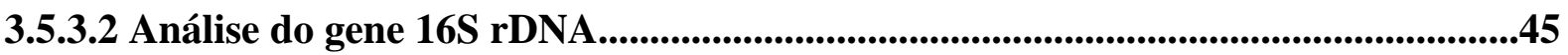

3.5.3.3 Construção de bibliotecas genômicas.............................................................................48

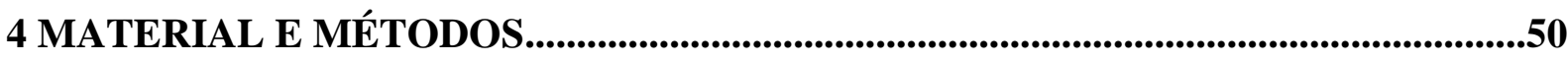

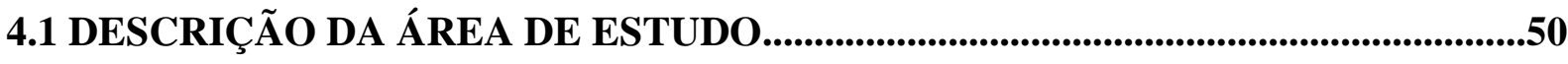

4.2 PERÍOdo DE AMOSTRAgem E LOCAIS DE COLETA DE AMOSTRAS DE

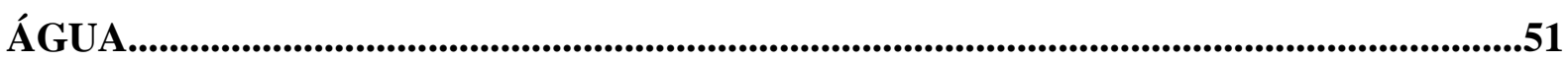

4.3 CARACTERIZAÇÃO FÍSICO-QUÍMICA DAS AMOSTRAS DE ÁGUA DO MAR.

4.4 CARACTERIZAÇÃo MICROBIOLÓGICA DAS AMOSTRAS DE ÁGUA DO MAR.

4.4.1 Contagem e isolamento de bactérias marinhas....................................................................54

4.4.2 Outras determinações...........................................................................................................54 
4.5 CARACTERIZAÇÃO MOLECULAR DOS ISOLADOS DE BACTÉRIAS

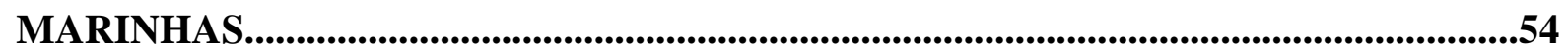

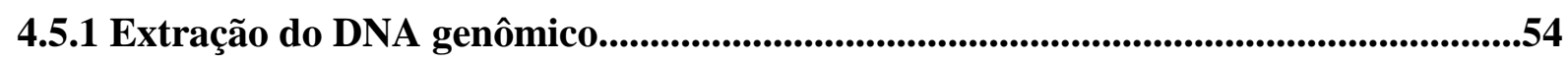

4.5.2 Tipagem molecular utilizando os métodos BOX-PCR e ERIC-PCR........................55

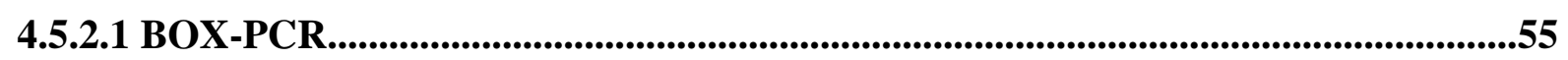

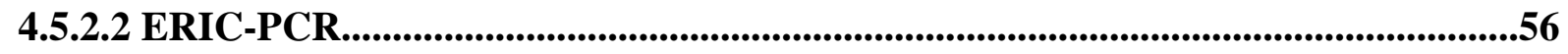

4.5.3 Verificação dos amplicons gerados pelas técnicas de BOX-PCR e ERIC-PCR.......56

4.5.4 Seqüenciamento parcial da região 16S rRNA dos isolados bacterianos....................56

4.5.4.1 Amplificação da região 16S rRNA....................................................................................56

4.5.4.2 Preparação das amostras para seqüenciamento...................................................57

4.5.4.3 Seqüenciamento parcial da região 16S rRNA........................................................57

4.6 DETERMINAÇÃO DA CONCENTRAÇÃO BACTERIANA PELA TÉCNICA DE HIBRIDIZAÇÃO in situ FLUORESCENTE (FISH)............................................................58

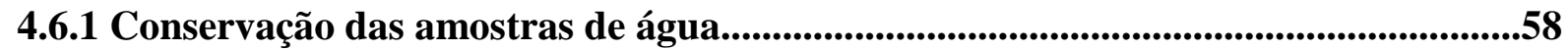

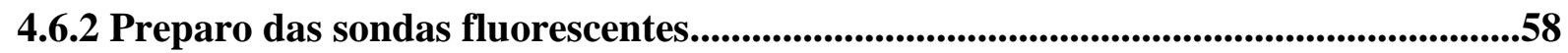

4.6.3 Hibridização in situ fluorescente e contagem direta de células pela técnica de microscopia. .59

4.7 CARACTERIZAÇÃO MOLECULAR DAS POPULAÇÕES BACTERIANAS: CONSTRUÇÃO DE BIBLIOTECAS DO GENE 16S rDNA............................................61

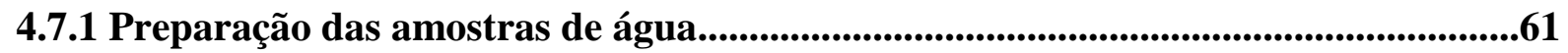

4.7.2 Extração do DNA total das amostras de água do mar......................................................61

4.7.3 Amplificação da região 16S rRNA do DNA total.................................................62

4.7.4 Preparação das amostras para clonagem...........................................................63

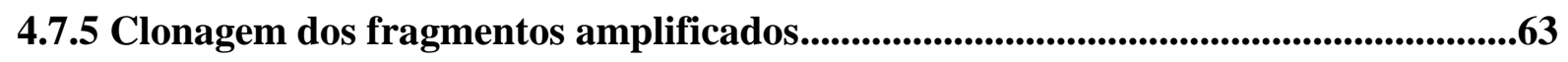

4.7.5.1 Preparação das células eletrocompetentes...........................................................63

4.7.5.2 Ligação fragmento-vetor e transformação das células competentes........................64

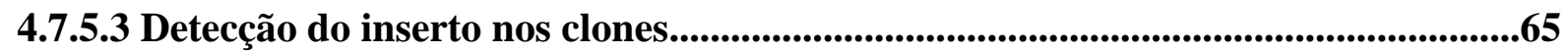

4.7.6 Preparação dos clones para seqüenciamento...................................................................66

4.7.7 Seqüenciamento dos clones de 16S rRNA............................................................66

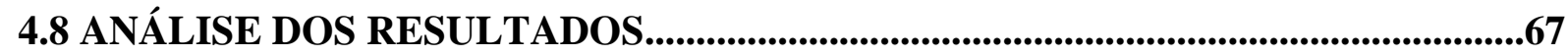

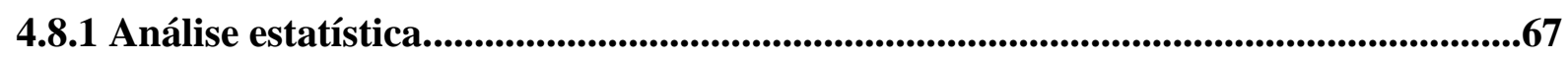


4.8.2 Análise dos agrupamentos obtidos na tipagem molecular por BOX-PCR e ERICPCR.

4.8.3 Análise das seqüências de 16S rRNA de isolados bacterianos e de bibliotecas de clones. .68

4.8.4 Índices de Diversidade e Riqueza das bibliotecas gênicas. .069

5 RESULTADOS .070

5.1 COLETA DE AMOSTRAS DE ÁGUA DO MAR. .70

5.2 CARACTERIZAÇÃO FÍSICO-QUÍMICA DAS AMOSTRAS DE ÁGUA DO MAR . .70

5.3 CARACTERIZAÇÃO MICROBIOLÓGICA DAS AMOSTRAS DE ÁGUA DO MAR. . .71

5.3.1 Contagem e isolamento de bactérias marinhas . .71

5.3.2 Caracterização fenotípica das bactérias marinhas. .72

5.3.3 Qualidade microbiológica das amostras de água do mar. . .73

5.4 CARACTERIZAÇÃO MOLECULAR DOS ISOLADOS DE BACTÉRIAS MARINHAS. .074

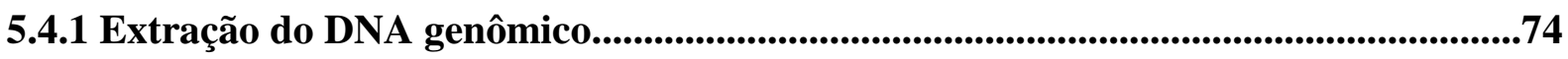

5.4.2 Tipagem molecular utilizando os métodos BOX-PCR e ERIC-PCR........................75

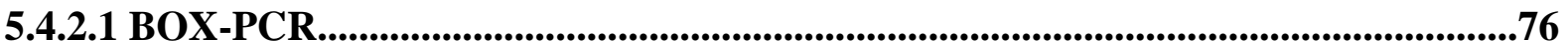

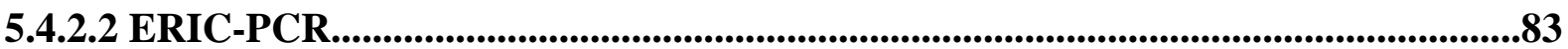

5.4.3 Seqüenciamento parcial da região 16S rRNA dos isolados bacterianos. .87

5.5 DETERMINAÇÃO DA CONCENTRAÇÃO BACTERIANA PELA TÉCNICA DE HIBRIDIZAÇÃO in situ FLUORESCENTE (FISH). 102

5.6 CARACTERIZAÇÃO MOLECULAR DAS POPULAÇÕES BACTERIANAS: CONSTRUÇÃO DE BIBLIOTECAS DO GENE 16S rDNA 110

5.6.1 Extração do DNA total das amostras de água do mar. .110

5.6.2 Clonagem dos fragmentos amplificados. 111

5.6.3 Seqüenciamento dos clones de 16S rRNA .111

5.6.3.1 Índices de Diversidade e Riqueza das bibliotecas gênicas.....................................126

6 DISCUSSÃO. .133

6.1 CARACTERIZAÇÃO FÍSICO-QUÍMICA DO CANAL DE SÃO SEBASTIÃO...133 
6.2 CARACTERIZAÇÃO MICROBIOLÓGICA DAS AMOSTRAS DE ÁGUA DO MAR. .0134

6.2.1 Contagem e isolamento de bactérias marinhas..........................................................134

6.2.2 Caracterização fenotípica das bactérias marinhas.......................................................137

6.2.3 Qualidade microbiológica das amostras de água do mar........................................137

6.4 CARACTERIZAÇÃO MOLECULAR DOS ISOLADOS DE BACTÉRIAS

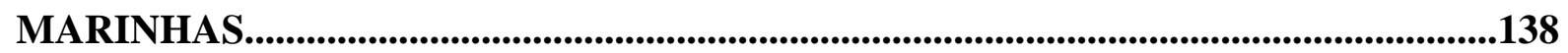

6.4.1 Tipagem molecular utilizando os métodos BOX-PCR e ERIC-PCR.......................138

6.4.2 Seqüienciamento parcial da região 16S rRNA dos isolados bacterianos..................140

6.5 DETERMINAÇÃO DA CONCENTRAÇÃO BACTERIANA PELA TÉCNICA DE HIBRIDIZAÇÃO in situ FLUORESCENTE (FISH)......................................................144

6.6 CARACTERIZAÇÃO MOLECULAR DAS POPULAÇÕES BACTERIANAS: CONSTRUÇÃO DE BIBLIOTECAS DO GENE 16S rDNA........................................146

6.6.1 Seqüenciamento dos clones de 16S rRNA................................................................146

6.6.2 Índices de Diversidade e Riqueza das bibliotecas gênicas.......................................149

6.7 COMPARAÇÃO ENTRE AS METODOLOGIAS EMPREGADAS...........................150

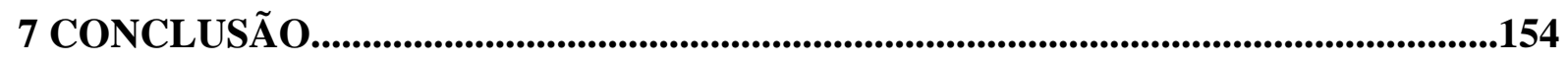

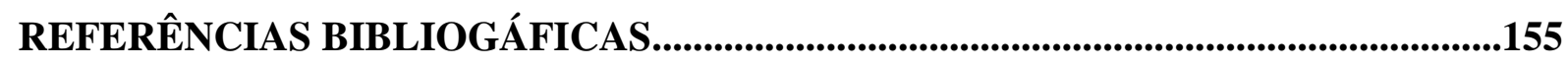

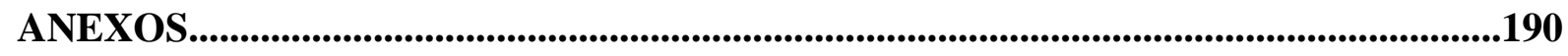

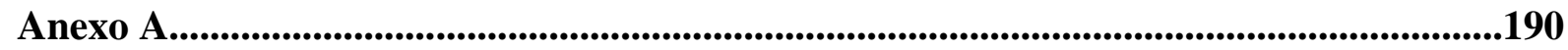

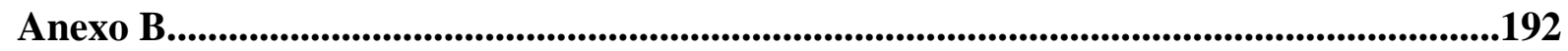

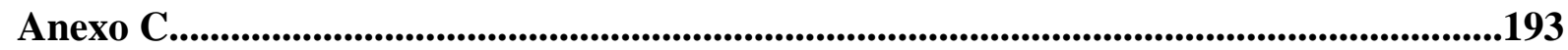




\section{INTRODUÇÃO}

Geralmente, o homem tende a perceber o universo a partir do seu ponto de vista, de modo que só observa aquilo que seus olhos conseguem ver, como por exemplo, uma grande variedade de animais e plantas. Contudo, mais além daquilo que é visível ao olho humano existe um mundo completamente novo e, em grande parte, desconhecido no qual se desenvolve um número inimaginável de microrganismos. Apesar do tamanho pequeno, os microrganismos são as formas de vida mais abundantes e variadas e, estima-se que constituam tanta biomassa quanto o restante dos seres vivos em nosso planeta (WHITMAN et al., 1998; NEE, 2003, 2004).

Os microrganismos, constituídos por membros pertencentes aos domínios Bacteria, Archaea e Eucarya (WOESE et al., 1990), são essenciais para a conservação do nosso planeta e às formas de vida de sua biosfera, visto que esses controlam os ciclos biogeoquímicos e participam da manutenção dos ecossistemas (WHITMAN et al., 1998). Sendo assim, se a conservação das formas de vida do nosso planeta é de importância vital, o estudo da ampla variedade de microrganismos, especialmente daqueles que ainda são desconhecidos, deveria constituir uma das linhas principais na conservação da diversidade biológica (COLWELL, 1997).

Apesar da grande importância desses seres para a manutenção da biosfera e embora a microbiologia tenha sido desenvolvida com o cultivo de microrganismos foi comprovado que os microbiologistas são capazes de cultivar somente uma parte mínima (geralmente inferior a $1 \%$ do total) dos microrganismos presentes em qualquer ambiente (WARD et al., 1990; COLWELL, 1997; TORSVIK et al., 2002). No entanto, em virtude do desenvolvimento de ferramentas de biologia molecular e com o auxílio do microscópio foi confirmada a existência de um grande número de microrganismos na natureza muito superior ao que era detectado utilizando técnicas de cultivo (KEPNER e PRATT, 1994).

Recentemente, o emprego de técnicas moleculares baseadas na identificação de microrganismos por seqüências específicas do $16 \mathrm{~S}$ rRNA ou de genes cromossomais que os codificam, com o auxílio da bioinformática, ciência que emprega métodos computacionais, matemáticos e estatísticos para organizar e analisar dados biológicos em grande escala e de maneira íntegra, têm demonstrado que o mundo microbiano é altamente diverso e a maioria das espécies de microrganismos está por serem descobertas (SCHLOSS e HANDELSMAN, 2004). 
No Brasil, apesar dos ecossistemas marinhos serem complexos e únicos, abrangendo desde recifes de corais com elevados níveis de endemismo até extensas áreas de manguezais ainda preservadas, poucos são os trabalhos que envolvem esse ecossistema. Contudo, os trabalhos que estão sendo feitos não estão diretamente ligados à diversidade bacteriana marinha, mas sim relacionados à diversidade bacteriana associada a recifes de corais (REIS et al., 2009) e esponjas marinhas (HARDOIM et al., 2009).

Por outro lado, trabalhos recentes têm mostrado que a diversidade microbiana brasileira vem sendo estudada, não no que diz respeito às comunidades marinhas, mas sim em comunidades microbianas associadas a sedimento (DIAS et al., 2009; RODRIGUES et al., 2009), rochas (von der WEID et al., 2008), solos (OLIVEIRA et al., 2006a; ABOIM et al., 2008) e plantas (ANDREOTE et al., 2009).

Desta maneira, o presente trabalho procurou caracterizar a diversidade bacteriana no ecossistema marinho do Canal de São Sebastião dando enfoque às comunidades bacterianas tanto cultivadas como comunidades totais, pois independente de qual seja a abordagem, não há dúvida de que estudos baseados em microrganismos cultivados e em comunidades totais possibilitarão o avanço na compreensão dos processos microbianos no ecossistema marinho. 


\section{OBJETIVOS}

\subsection{OBJETIVO GERAL}

Baseado no pressuposto que o ambiente marinho possui uma ampla variedade bacteriana pertencente ao Filo Proteobacteria e que a comunidade cultivável é consideravelmente menor que a total, parte-se da hipótese de que a diversidade bacteriana do Canal de São Sebastião não seja diferente disso. Assim, o presente estudo visa analisar a diversidade bacteriana cultivada e não-cultivada, durante o período de 20 meses, no ecossistema marinho do Canal de São Sebastião, levando-se em consideração diferenças sazonais que possam existir no local.

\subsection{OBJETIVOS ESPECÍFICOS}

- Quantificar, através de contagem em placa, bactérias marinhas viáveis em amostras de água do mar coletadas no Canal de São Sebastião;

- Caracterizar a diversidade das bactérias viáveis, com ênfase no Filo Proteobacteria, através das técnicas de BOX-PCR, ERIC-PCR e seqüenciamento da região 16S rRNA;

- Quantificar a comunidade total dos grupos bacterianos alpha-, beta-, gamma- e deltaproteobacteria através de sondas fluorescentes utilizando-se a metodologia de contagem direta;

- Caracterizar a diversidade da comunidade bacteriana total da água do mar através da construção de bibliotecas genômicas;

- Comparar a diversidade das populações bacterianas cultivadas e totais. 


\section{REVISÃO BIBLIOGRÁFICA}

\subsection{ECOLOGIA MICROBIANA MARINHA}

A ecologia microbiana marinha estuda o papel dos microrganismos na dinâmica biogeoquímica de ecossistemas marinhos naturais. Pesquisas conduzidas principalmente durante a última metade do século construiu uma compreensão coerente da função que os microorganismos desempenham na economia geral do mar (KARL e PROCTOR, 2007).

De acordo com a atual árvore filogenética (Figura 1), os microrganismos estão classificados em três domínios: Archaea, Bacteria e Eucarya (WOESE, 1994). Estes domínios são identificados pela distância genética na composição das moléculas de $16 \mathrm{~S}$ ou 18S rRNA (WOESE et al., 1990). Os domínios Bacteria e Archaea representam a divisão dos procariotos, organismos com parede celular rígida que não apresentam o DNA limitado por uma membrana nucléica. Já o domínio Eucarya é representado por organismos que possuem um núcleo celular rodeado por uma membrana, como as algas unicelulares (exceto as cianobactérias), fungos, protistas flagelados e ciliados, plantas e animais.

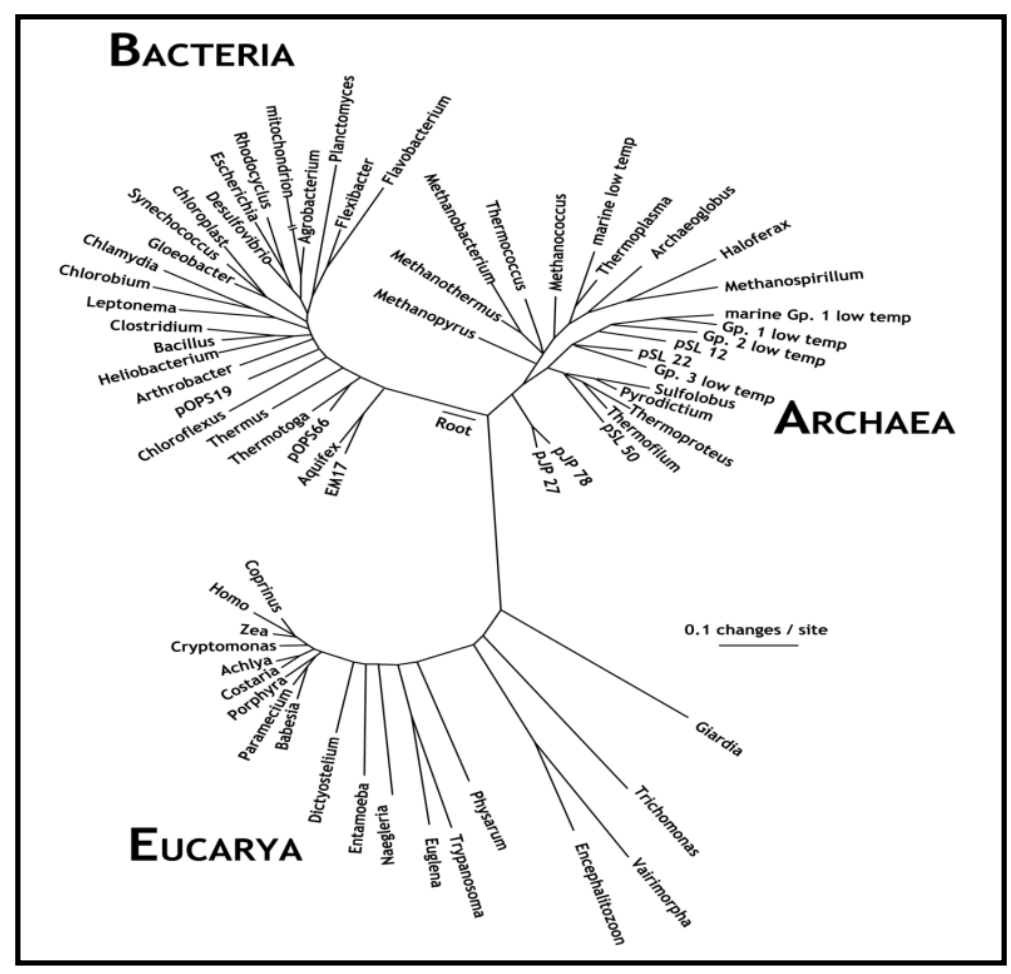

Figura 1 - Árvore filogenética universal baseada nas sequências de 16S rRNA, mostrando 64 sequências de rRNA de todos os domínios filogenéticos conhecidos.

FONTE: PACE, 1997. 
Os microrganismos compõem umas das maiores fontes de diversidade genética disponível entre os seres vivos, sendo os procariotos responsáveis pela maior parte dessa biota. Embora pequenos $\left(\sim 10^{-6} \mathrm{~m}\right)$, eles são abundantes $\left(>10^{30}\right.$ indivíduos). No entanto, esta diversidade encontra-se ainda pouco descrita e explorada (PROSSER et al., 2007).

A vida no ecossistema marinho é dominada, tanto em termos de biomassa como de metabolismo, pelos microrganismos dos três domínios da vida (Archaea, Bacteria e Eucarya). Esses microrganismos são taxonomicamente diversos e metabolicamente complexos e muitos dos grupos importantes ainda não foram cultivados em laboratório (KARL, 2007).

Sabe-se que a riqueza conhecida e estimada da diversidade microbiana está representada por 75 mil e 1,5 milhões espécies de fungos, 4.900 mil e 1 milhão de bactérias e 4 mil e 400 mil de vírus, respectivamente (HAMMOND, 1995; HAWKSWORTH, 2001; FROESE e BISBY, 2002). Esses dados sugerem que o número de espécies descritas de fungos, bactérias e vírus são 5\%,0,5\% e 1\%, respectivamente, do número total de espécies existentes.

Tendo em vista que a avaliação total de procariotos na Terra poderia ser feita analisando a variação de habitats representativos, foi verificado que a maioria dos procariotos ocorre em solos, sedimentos e oceanos, sendo $3,5 \times 10^{30}, 1,4 \times 10^{30}$ e $0,12 \times 10^{30}$ o número de células estimado para estes respectivos ambientes. Por outro lado, os números estimados em outros ambientes foram de, no mínimo, 6 ordens de magnitudes a menos (WHITMAN et al., 1998).

A vida microbiana existe em todos os locais onde os microrganismos podem sobreviver (GOLD, 1992). As vastas extensões dos oceanos, juntamente com lagos, rios e lagoas, fornecem a maior parte da vida na Terra. Inúmeros nichos ambientais estão presentes nos oceanos - alguns quentes, alguns frios, alguns na superfície e ainda mais nas altas pressões das profundezas. Na verdade, algumas das mais extremas condições de vida podem ser encontradas nos oceanos (JONES, 2007).

Apesar do papel vital e indiscutível dos microrganismos marinhos no ecossistema global, o ambiente marinho continua lamentavelmente subexplorado. De fato, até recentemente, o estudo de ambientes oceânicos foi prejudicado por barreiras técnicas significantes. Estas incluíam a dificuldade da coleta de amostras representativas de alguns dos nichos mais difíceis de serem alcançados (JONES, 2007).

Informações sobre estudos da diversidade microbiana em água do mar, água doce, solo, ar, ambientes poluídos e não poluídos e diversos outros ambientes estão disponíveis na 
literatura (COLWELL, 2006). Num desses estudos utilizando a microscopia foi estimado que, em água do mar, água doce, águas estuarinas, sedimentos e solos, somente 0,0001-0,1\%, $0,25 \%, 0,1-3 \%, 0,25 \%$ e $0,3 \%$, respectivamente, das células bacterianas totais são acessíveis aos métodos de cultivo tradicional (AMANN et al., 1995).

O ambiente marinho é o maior habitat contíguo na Terra que abriga ecossistemas singulares e riquíssimos em biodiversidade (HARPER e HAWKSWORTH, 1995). No entanto, mesmo sem fronteiras rígidas, sabe-se atualmente que o oceano é um mosaico de habitats semi-isolados que são estabelecidos e mantidos pelas interações das escalas globais entre a atmosfera e o oceano (LONGHURST, 1998).

Os oceanos cobrem, aproximadamente, $71 \%$ da superfície da Terra e têm, em média, 4 $\mathrm{km}$ de profundidade. Perto das fronteiras continentais, os habitas marinhos são geralmente menores, devido à presença de plataformas continentais expansivas que tem, no máximo, algumas centenas de metros de profundidade (10-200 km). Mais próximo ao continente, os habitats marinhos são influenciados pela entrada de materiais provenientes do continente, como sedimentos, água, carbono orgânico e nutrientes que aumentam a variabilidade do hábitat e afetam a produtividade microbiana (KARL, 2007).

Desde que começou a vida, provavelmente nos oceanos, microrganismos marinhos são os descendentes mais próximos das formas originais de vida. Eles habitam todos os ecossistemas marinhos, desde águas superficiais até o abismo mais profundo a mais de 11.000 metros, local conhecido como Fossa das Marianas (WHITMAN et al., 1998). Eles também são importantes pilares da biosfera e seu metabolismo permite que um único microrganismo marinho possa realizar muitas das etapas dos ciclos biogeoquímicos que outros organismos são incapazes de desempenhar (ATLAS e BARTHA, 1993).

Os microrganismos marinhos são os grupos de organismos mais numerosos do planeta possuindo a maior diversidade genética existente, mas, apesar disso, a maior parte das espécies permanece desconhecida e, além de abundantes, também são capazes de se adaptar a muitos ambientes extremos no oceano (WHITMAN et al., 1998; ROSSELLÓ-MORA e AMANN, 2001; KIRCHMAN, 2008).

\subsection{DEFININDO ESPÉCIES PROCARIÓTICAS}

Historicamente, a definição de espécie microbiana foi realizada pelo emprego de métodos baseados em cultivo de microrganismos em laboratório. Em 2004, Woese propôs a 
definição atual de espécies, após verificar os enganos da definição anterior, a qual incluía todas as bactérias dentro de um grupo chamado procariotos e afirmava que todas tinham vindo de um ancestral procariótico comum (STANIER e NIEL, 1962; STANIER et al., 1963). Fundamental para a avaliação da diversidade microbiana é compreender a unidade de medida de diversidade, ou seja, a espécie microbiana.

O campo da taxonomia procariótica obteve seu maior crescimento durante o século 20 e, hoje, o conceito de espécies procarióticas tem mudado ao que diz respeito ao que era pensado ser apenas uma unidade. Todavia ainda há controvérsias (ROSSELLÓ-MORA e KÄMPFER, 2004). O termo, geralmente, denota membros do domínio Bacteria e Archaea, assim como alguns membros microscópicos do domínio Eucarya, como algas unicelulares, alguns fungos e protistas. Uma definição mais concisa foi oferecida chamando de microrganismo aquele que tem uma massa inferior a $10^{-5}$ gramas e um comprimento inferior a $500 \mu \mathrm{m}($ MARTINY et al., 2006).

A definição de uma espécie procariótica é um tema que ainda gera muitas discussões entre os taxonomistas, já que a classificação e a descrição adequada de uma bactéria requerem conhecimento de suas características morfológicas, bioquímicas, fisiológicas e genéticas. E como uma ciência, a taxonomia é dinâmica e está sujeita a mudanças com bases nos dados que estão disponíveis (BRENNER et al., 2005). Contudo, uma espécie procariótica, geralmente, é considerada "uma coleção de cepas que mostra um alto grau de similaridade total e diferem, consideravelmente, quando comparados a outros grupos de cepas relatados" (COLWELL et al., 1995).

Para a maioria dos organismos eucarióticos, como plantas, animais, fungos e alguns protistas, uma espécie é definida como um cruzamento entre as populações. Mas as bactérias não usam esse cruzamento como principal mecanismo para troca de DNA. Em vez disso, elas adquirem fragmentos de DNA por recombinações, ou seja, através da transferência horizontal de genes. Sendo assim, uma definição para espécie bacteriana tem sido baseada na técnica de hibridização DNA-DNA comparada com as seqüências de gene 16S rDNA de espécies bacterianas mostrando fenótipos semelhantes (FUHRMAN e HAGSTRÖM, 2008).

Várias abordagens estatísticas têm sido utilizadas para estimar e comparar a diversidade de procariotos, bem como as estruturas de suas comunidades em diferentes ambientes. Normalmente a diversidade e estrutura das comunidades microbianas são analisadas em função da ocorrência de unidades taxonômicas operacionais (Operational 
Taxonomic Units - OTUs) ou filotipos, já que o conceito de espécies, principalmente para os procariotos, é controverso (ROSSELLÓ-MORA e AMANN, 2001).

Os critérios para a definição das OTUs não são consensuais, principalmente quando se discute a distância evolutiva limite para que uma seqüência represente uma OTU. Normalmente, seqüências com similaridade > 97\% são consideradas da mesma espécie, > 95\% do mesmo gênero e > 80\% do mesmo filo (STACKEBRANDT e GÖBEL, 1994; BOND et al., 1995; BORNEMAN e TRIPLETT, 1997; HUGENHOLTZ et al., 1998a; EVERETT et al., 1999; McCAIG et al., 1999; SAIT et al., 2003).

Em conformidade a estes critérios, organismos que apresentam $\leq 97 \%$ de similaridade com o gene $16 \mathrm{~S}$ rDNA ou menos que $70 \%$ com a hibridização DNA-DNA foram propostos como pertencentes a espécies diferentes (STACKEBRANDT e GÖBEL, 1994). Esta delimitação tem sido amadurecida ao ponto que o assunto já é descrito nos principais livros didáticos (MADIGAN e MARTINKO, 2006). Por conseguinte, estes valores de cutoff são os que mais se adéquam à taxonomia histórica, mas ainda não podem ser considerados rigorosamente válidos para uma classificação hierárquica precisa (SCHLOSS e HANDELSMAN, 2005).

Por outro lado, Konstantidinis et al. (2006) e outros autores defendem a hipótese de que as bactérias formam clusters genômicos que são caracterizados por propriedades fenotípicas distintas (TEMPLETON, 1989; DYKHUIZEN e GREEN, 1991; ROSSELLÓMORA e AMANN, 2001; COHAN, 2002; GEVERS et al., 2005). É comum a interpretação que organismos que possuem mais de $97 \%$ de similaridade em suas seqüências sejam da mesma espécie, mas isso não necessariamente é verdade. Por exemplo, com uma similaridade $\geq 97 \%$ várias subclasses de Cianobactérias fenotipicamente distintas formam uma única espécie (CARR e MANN, 1994; WEST et al., 2001; CASAMAYOR et al., 2002; RODRIGUEZ et al., 2005).

Segundo Gevers et al. (2005) não há um conceito mundialmente aceito para espécies de procariotos e a atribuição de isolados a espécies depende da similaridade fenotípica ou genômica. Esses autores afirmam ainda que o MLST (Multilocus Sequence Typing) é o método mais robusto para identificar fronteiras entre espécies bacterianas. Por outro lado, nem a hibridização DNA-DNA usada para "calibrar" o método de seqüenciamento do gene 16S rDNA nem o MLST são apropriados para estudos ambientais onde as comunidades contêm uma grande fração de bactérias que não podem ser isoladas em meio de cultura (FUHRMAN e HAGSTRÖM, 2008). 
Enquanto a legitimidade do conceito continua sendo questionada, uma retratação importante para a discussão em questão é salientar a atual incerteza quanto à delimitação das espécies bacterianas, uma vez que certas condições básicas devem ser levadas em conta para que um organismo seja considerado como espécie (BACHMANN, 1998).

\subsection{DIVERSIDADE BACTERIANA MARINHA}

Dentre os microrganismos, as bactérias apresentam longa história evolutiva, o que permitiu a elas ocupar os mais diferentes nichos da biosfera sendo encontradas em todos os ambientes (RODRIGUEZ-VALERA, 2004). As bactérias representam a maior biomassa viva no planeta e apresentam uma impressionante diversidade genética, a qual excede, em muito, a diversidade de organismos superiores, sendo responsáveis por muitos processos essenciais para a manutenção da vida nas condições ambientais atuais (WARD, 1998; HUNTERCEVERA, 1998).

Historicamente, os oceanógrafos acreditavam que a maior parte da produção primária era movida através de uma cadeia de pequenos e grandes animais (POMEROY, 1974; WILLIAMS, 1981a; AZAM e AMMERMAN, 1984) e os microrganismos foram amplamente ignorados (STEELE, 1974). Por outro lado, várias descobertas notáveis que foram feitas durante os últimos 30 anos têm demonstrado que as bactérias são abundantes e apresentam uma diversidade e atividade metabólica muito ampla nos oceanos (HOBBIE et al., 1977; FUHRMAN e AZAM, 1980; HAGSTRÖM et al., 1979). A maior parte da matéria orgânica dissolvida que é utilizada na produção primária, é utilizada quase que exclusivamente por bactérias heterotróficas e Archaea (AZAM e MALFATTI, 2007).

As bactérias nos ecossistemas aquáticos foram inicialmente reconhecidas pelo seu papel na decomposição de material orgânico e inorgânico e na remineralização de nutrientes, papel este que só foi aceito plenamente na década de 1980 (DUCKLOW, 1983; DUCKLOW et al., 1986). A sua importância como produtoras fotossintéticas de matéria orgânica tornou-se evidente quando as chamadas algas verdes-azuis foram reconhecidas como sendo bactérias, e as cianobactérias microscópicas do gênero Synechococcus foram descobertas por serem abundantes nos oceanos, especialmente nos vastos ambientes oligotróficos onde elas são os autótrofos dominantes (POMEROY et al., 2007).

O termo bactéria e bacterioplâncton, historicamente, têm sido reservados para procariotos heterotróficos, embora este já não seja aceitável baseado em nossa compreensão 
atual da vida marinha, visto que as bactérias não são todas heterotróficas e nem todos os procariotos heterotróficos são bactérias (KARL, 2007).

A distribuição, a abundância das espécies e os fatores que as controlam são essenciais para a compreensão do funcionamento dos ecossistemas e das respostas às mudanças ambientais (CHAPIN et al., 2000). Estudos sobre a distribuição espacial e temporal e abundância de táxons foram feitos, em sua maioria, em animais e plantas (espécies macrobianas) e não em espécies microbianas como as bactérias (MORIN, 1999; LOREAU et al., 2001; ELSE e STERNER, 2002, HOOPER et al., 2005). Contudo, tornou-se evidente que as bactérias são as espécies dominantes tanto em termo de abundância relativa (densidades ou biomassa) como em termos de contribuição para os processos do ecossistema (FUHRMAN et al., 1989; WHITMAN et al., 1998; AZAM e WOEDEN, 2004).

O ecossistema marinho, em particular, é menos estudado, mas tem sido provado altos índices de distribuição e abundância de táxons dominantes de plâncton procariótico, como os grupos bacterianos dos clusters do SAR-11 que estão presentes na maioria dos oceanos (MORRIS et al., 2002). Assim também, foi relatado recentemente uma das mais interessantes descobertas do ambiente marinho - a bactéria Pelagibacter ubique (SAR-11) uma das menores células que se auto-duplicam, a qual possui apenas 1354 genes (GIOVANNONI et al., 2005).

Estima-se que os oceanos contenham $10^{29}$ bactérias (WHITMAN et al., 1998), um número maior do que o estimado de estrelas $\left(10^{21}\right)$ no universo. A sua grande abundância numérica é devido ao seu tamanho, 0,2-0,6 $\mu \mathrm{m}$ de diâmetro. A massa total de bactérias no oceano excede a massa combinada de zooplâncton e peixes (POMEROY et al., 2007).

A diversidade que nós vemos hoje em comunidades microbianas é o resultado de cerca de 4 bilhões de anos de mudanças evolucionária. Esta diversidade microbiana pode ser vista de várias maneiras, como por exemplo, através das variações no tamanho e morfologia da célula, estratégias metabólicas, mecanismos de divisão celular, patogenicidade, adaptação a ambientes extremos e muitos outros aspectos da biologia celular (MADIGAN e MARTINKO, 2006).

A composição das comunidades microbianas nos ecossistemas pode ser afetada por inúmeros fatores bióticos e abióticos. Trabalhos têm mostrado que as variações nas condições ambientais, como as mudanças climáticas são, em parte, responsáveis pelas variações espaciais da diversidade de microrganismos, apesar de alguns estudos demonstrarem uma distribuição mais ubíqua (HUNTER-CEVERA et al., 2005; MARTINY et al., 2006). 
Várias tentativas empíricas e teóricas foram feitas para estimar a riqueza das espécies microbianas (BULL e STACH, 2004). As estimativas mais úteis são aquelas de Hammond (1995), onde este descreveu cerca de 13,6 milhões de espécies microbianas tentando acurar a estimativa mais provável. Somente nas últimas décadas têm sido desenvolvidos métodos e conceitos para explorar o significado de microrganismos no ciclo de vida nos oceanos (POMEROY et al., 2007).

\subsection{PROTEOBACTÉRIAS}

O domínio Bacteria contém uma enorme variedade de morfologias e características fisiológicas e dentro desse domínio, o Filo Proteobacteria constitui, até o momento, o maior e mais diverso grupo filogenético fenotipicamente (KERSTERS et al., 2006).

Este grupo de organismos foi originalmente proposto como a Classe Proteobacteria por Stackebrandt et al. (1988) e continha quatro subclasses nomeadas informalmente. No entanto, Garrity e Holt (2001) propuseram elevar esta Classe ao nível de Filo e, em 2002, as Proteobactérias eram constituídas por mais de 460 gêneros e mais de 1.600 espécies dispersas ao longo deste grupo. No final de 2003, o grupo das Proteobactérias já continha 2.279 espécies nomeadas, as quais estavam distribuídas em 521 gêneros (GARRITY et al., 2005).

Recentemente, este consenso mudou um pouco, pois sequências adicionais foram inseridas às análises filogenéticas e hoje essas espécies estão distribuídas ao longo de cinco linhagens filogenéticas dentro deste filo: Alphaproteobacteria $(\alpha)$, Betaproteobacteria $(\beta)$, Gammaproteobacteria $(\gamma)$, Deltaproteobacteria $(\delta)$ e Epsilonproteobacteria $(\varepsilon)$, baseado na sequência 16S rRNA (Figura 2) (KERSTERS et al., 2006).

As Proteobactérias correspondem a mais de $40 \%$ de todos os gêneros procarióticos validamente publicados e incluem a maior proporção de cocos e bacilos gram-negativos (HOLT, 1984; BALOWS et al., 1992; HOLT et al., 1994; COLLIER et al., 1998; STACKEBRANDT et al., 1988), apresentam extrema diversidade metabólica e são de grande importância biológica, uma vez que incluem a maioria das bactérias Gram-negativas de interesse médico, veterinário, industrial e agrícola (KERSTERS et al., 2006; MADIGAN e MARTINKO, 2006).

As Proteobactérias, conhecidas formalmente como "bactérias púrpuras", são caracterizadas por uma vasta diversidade de tipos fisiológicos e morfológicos: além de cocos e bacilos, bactérias curvas, espirais, em formato de anel e filamentosas ocorrem neste Filo. A 
maioria das Proteobactérias são mesofílicas, mas alguns representantes termofílicos (Thiomonas thermosulfata e Tepidomonas) e psicrofílicos (Polaromonas) também têm sido descritos e a maioria é de vida livre, mas algumas encontram-se em associação simbiótica com plantas leguminosas específicas (GARRITY et al., 2005).

No que se refere aos mecanismos de geração de energia, algumas são quimiorganotróficas (Escherichia coli), outras são quimiolitotróficas (Thiobacillus e Nitrosomonas) ou fototróficas (Chromatium e Rhodospirillum). Para revelar a ampla biodiversidade fenotípica entre as Proteobactérias, a tabela 1 dá uma visão geral da distribuição dos 5 grupos filogenéticos da classe Proteobacteria entre os 13 maiores grupos fenotípicos como definidos na $9^{\text {th }}$ edition of Bergey's Manual of Determinative Bacteriology (HOLT et al., 1994).

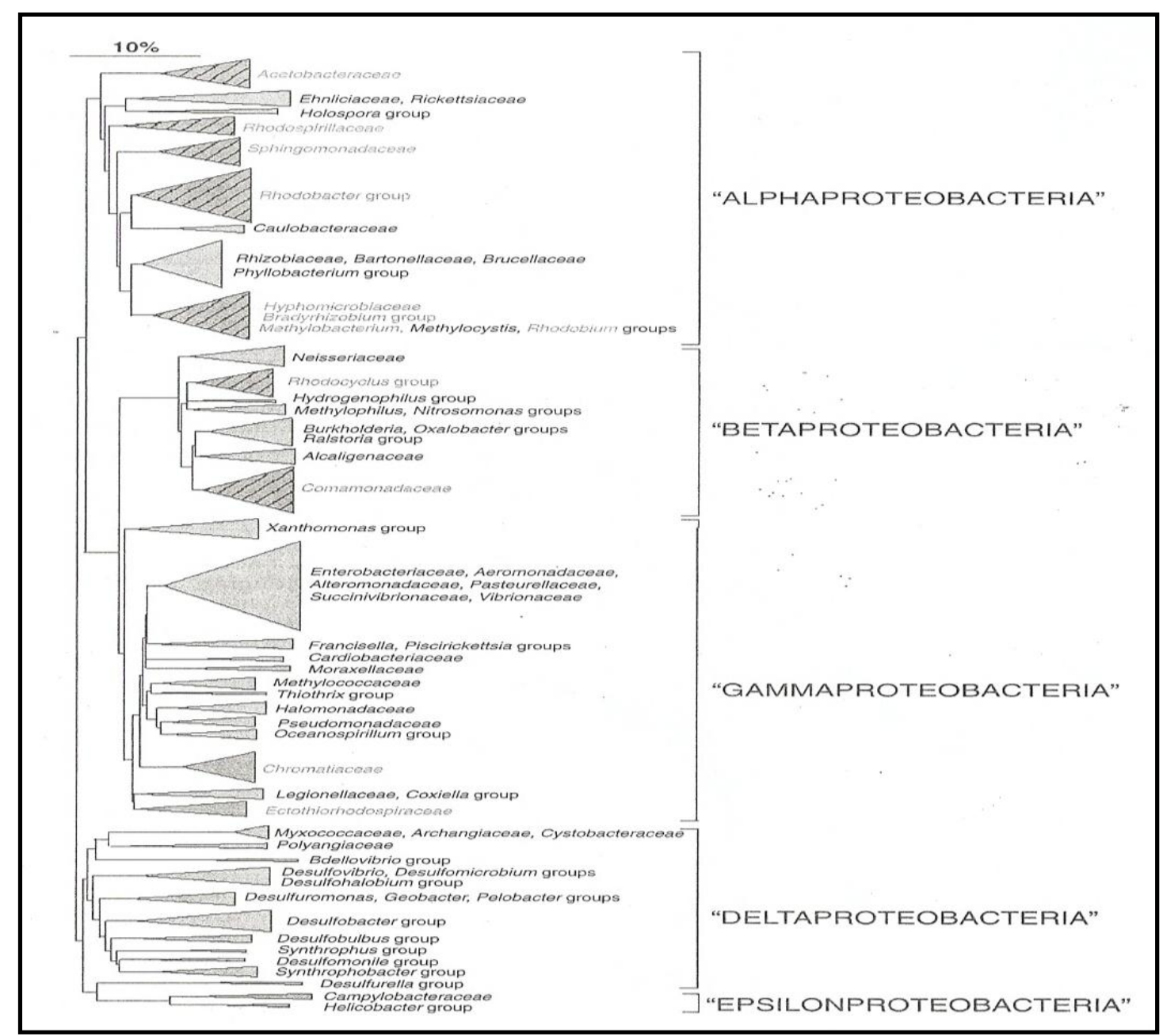

Figura 2 - Árvore filogenética simplificada do Filo Proteobacteria baseada na sequência do gene 16S rDNA mostrando os gêneros que fazem parte das classes das proteobactérias. A largura dos triângulos é proporcional ao número de gêneros dentro de cada cluster.

FONTE: KESTERS et al., 2006. 
Tabela 1 - Ocorrência dos maiores grupos fenotípicos entre as cinco classes das Proteobactérias.

\begin{tabular}{|c|c|c|}
\hline Grupo Fenotípico a & $\begin{array}{l}\text { Número do } \\
\text { Grupo }\end{array}$ & $\begin{array}{c}\text { Ocorrência } \\
\text { na classe das } \\
\text { Proteobactérias }\end{array}$ \\
\hline $\begin{array}{l}\text { Bactéria Gram-negativa aeróbica / microaerófila, móvel e } \\
\text { helicoidal / vibrióide }\end{array}$ & 2 & $\alpha, \beta, \gamma, \delta, \varepsilon$ \\
\hline Bactéria Gram-negativa aeróbica / microaerófila cocos e bacilos & 4 & $\alpha, \beta, \gamma, \delta, \varepsilon$ \\
\hline Bacilo Gram-negativo anaeróbico facultativo & 5 & $\alpha, \beta, \gamma, \delta, \varepsilon$ \\
\hline $\begin{array}{l}\text { Bacilo Gram-negativo estritamente anaeróbico / curvo e } \\
\text { helicoidal }\end{array}$ & 6 & $\beta, \gamma, \delta$ \\
\hline $\begin{array}{l}\text { Bactéria simbiótica e parasitária de espécies de vertebrados e } \\
\text { invertebrados }\end{array}$ & 9 & $\alpha, \gamma$ \\
\hline Bactéria fototrófica anóxica & 10 & $\alpha, \beta, \gamma$ \\
\hline Bactéria quimiolitotrófica aeróbica e gêneros associados & 12 & $\beta, \gamma, \varepsilon$ \\
\hline Bactéria não fototrófica & 13 & $\alpha, \gamma$ \\
\hline Bactéria não fotossintética & 15 & $\beta, \gamma$ \\
\hline Bactéria Gram-negativa não móvel / raramente móvel / curva & 3 & $\alpha, \varepsilon$ \\
\hline Bactéria dissimiladora de sulfato ou redutora de sulfato & 7 & $\delta$ \\
\hline Bactéria encapsulada & 14 & $\beta$ \\
\hline Bactéria com brotamento e/ou apêndices & 16 & $\delta$ \\
\hline $\begin{array}{l}\text { Os grupos fenotípicos e número dos grupos estão de acordo com } \\
\text { Bacteriology }\end{array}$ & Bergey's Mar & l of Determinative \\
\hline
\end{tabular}

\subsubsection{Alphaproteobacteria}

De acordo com a classificação atual, a classe Alphaproteobacteria é dividida em sete ordens: Rhodospirillales, Caulobacterales, "Parvularculales", Rhizobiales, Rhodobacterales, Rickettsiales e Sphingomonadales, os quais contêm 140 gêneros e 425 espécies até o momento (GARRITY et al., 2005; KERSTERS et al., 2006).

A grande maioria dos membros da classe Alphaproteobacteria vive em associação com eucariotos: alguns são patogênicos para humanos e animais (gênero Brucella) ou plantas (gênero Agrobacterium) e outros exibem um estilo de vida parasitário, causam doenças em 
humanos e mamíferos, são transmitidos por picadas de insetos e carrapatos (família Rickettsiaceae) ou vivem simbioticamente em raízes de plantas leguminosas (gêneros Rhizobium e Bradyrhizobium) (GARRITY et al., 2005).

\subsubsection{Betaproteobacteria}

A classe Betaproteobacteria também foi subdividida em sete ordens: Burkholderiales, Hydrogenophilales, “Methylophilales", "Neisseriales", Nitrosomonadales, Procabacteriales e Rhodocyclales com, no mínimo, 75 gêneros e 220 espécies (GARRITY et al., 2005).

Esse é um grupo monofilético representado pelas maiores linhagens filogenéticas compostas pelo complexo $\beta-\gamma$ proteobacteriano, chamado Chromatibacteria (Cavalier-Smith, 2002). É um grupo muito heterogêneo que possui algumas bactérias fixadoras de nitrogênio e alguns patógenos importantes para plantas, humanos e animais (famílias Neisseriaceae e Alcaligenaceae, entre outras) (GARRITY et al., 2005).

\subsubsection{Gammaproteobacteria}

Atualmente, a classe Gammaproteobacteria é subdividida em 13 ordens: Chromatiales, Aeromonadales, Alteromonadales, Cardiobacteriales, "Enterobacteriales", Legionellales, Methylococcales, Oceanospirillales, Pasteurellales, Pseudomonadales, Thiotrichales, "Vibrionales" e Xanthomonadales, as quais se distribuem entre os 180 gêneros e 750 espécies (GARRITY et al., 2005).

Esse é o maior grupo proteobacteriano que abriga alguns importantes patógenos humanos e animais (alguns gêneros da família Enterobacteriaceae e Pseudomonadaceae). É notável que a família Enterobacteriaceae seja conhecida desde 1937 como um grupo filogenético clássico (RAHN, 1937), o qual continua suportado pela taxonomia molecular moderna.

\subsubsection{Deltaproteobacteria}

A taxonomia da classe Deltaproteobacteria teve mudanças significativas nos últimos tempos. Até o momento, a classe é subdividida em oito ordens: "Desulfurellales", "Desulfovibrionales", "Desulfobacterales", "Desulfarcales", "Desulfuromonales", 
"Syntrophobacterales", "Bdellovibrionales" e Myxococcales, nos quais contém os 60 gêneros e as 160 espécies (GARRITY et al., 2005).

Do ponto de vista do estilo de vida e da morfologia, a classe Deltaproteobacteria é a mais peculiar porque contém bactérias que são predadoras de outros procariotos (Bdellovibrios), enquanto outras Deltaproteobacteria pertencentes às Mixobactérias exibem um complexo ciclo de vida (GARRITY et al., 2005).

\subsubsection{Epsilonproteobacteria}

A classe Epsilonproteobacteria representa a menor e a mais recente linhagem reconhecida dentro das Proteobactérias. Esta classe é representada por três ordens: Helicobacteraceae, Campylobacteraceae e "Nautiliaceae", compondo os 6 gêneros e as 50 espécies (GARRITY et al., 2005).

Comparado às múltiplas mudanças na classificação das outras quatro classes proteobacterianas, a classificação da epsilon-proteobacteria permaneceu bastante estável porque é um grupo cuja taxonomia foi reconhecida baseada nas comparações do 16S rDNA (GARRITY et al., 2005).

\subsection{MÉTODOS DE ESTUDO DAS COMUNIDADES BACTERIANAS}

\subsubsection{Isolamento e cultivo de bactérias}

Na maior parte do século 20, a avaliação das comunidades microbianas provenientes de amostras ambientais era realizada somente através de ferramentas não moleculares (ATLAS e BARTHA, 1993), como os métodos tradicionais de isolamento seletivo e cultivo para identificar as espécies ou os grupos funcionais, estimar a abundância relativa e determinar a estrutura das comunidades (AMANN et al., 1995). Porém, quando aplicadas em procariotos, todas estas técnicas sofrem limitações devido ao tamanho pequeno destes organismos e à complexidade de seus ambientes.

Estes métodos tradicionais de isolamento em meios de cultivo são as ferramentas mais amplamente utilizadas no estudo das comunidades bacterianas presentes nos mais diferentes ambientes (água, solo, plantas, entre outros). Muitos parâmetros influenciam a atividade e a densidade das populações que compõem as comunidades bacterianas, assim como a alta 
diversidade bacteriana presente nesses nichos torna difícil a exploração e o conhecimento detalhado destes ambientes (RASCHE et al., 2006).

As dificuldades encontradas são, principalmente, devido à falta de representatividade observada na comparação entre as comunidades criadas e cultivadas no seu próprio nicho ecológico com as comunidades bacterianas que são obtidas em meios de cultivo (FELSKE et al., 1999; EILERS et al., 2000). Diante disso, concluiu-se que apenas uma pequena porção da diversidade microbiana total é obtida usando técnicas de cultivo (TYSON e BANFIELD, 2005).

Uma maneira de tentar reverter essa situação é desenvolver técnicas de cultivo alternativas, modificando as condições de cultivo na tentativa de obter uma melhor representatividade das comunidades bacterianas na forma de isolados e permitindo a exploração de funções microbianas (HAMAKI et al., 2005). A mimetização do ambiente através da alteração da atmosfera, da disponibilidade de nutrientes e da suplementação de moléculas sinalizadoras pode resultar numa melhor acessibilidade e maior culturabilidade da comunidade bacteriana (STEVENSON et al., 2004; BRUNS et al., 2002; BRUNS et al., 2003).

Mesmo sendo de suma importância para o estudo dos microrganismos, os métodos tradicionais fornecem dados insuficientes para analisar a diversidade microbiana em amostras ambientais, pois os resultados subestimam os valores reais encontrados na natureza. Isso ocorre devido à escassez de informações sobre a ecologia microbiana, como substratos específicos para a sobrevivência e crescimento, além de fatores como a sazonalidade (TORSVIK e OVREAS, 2002).

Outra limitação de estudos das comunidades microbianas baseados em cultivo é que, devido ao estresse ambiental, como baixas temperaturas, choque térmico, alta concentração de salinidade, falta de nutrientes e outros fatores (ROSZACK et al., 1984; GRIMES et al., 1986; COLWELL et al., 1990) algumas espécies de bactérias podem entrar no estado chamado de “viável mas não cultivável” (ROSZACK e COLWELL, 1987; OLIVER, 2000). Neste estado, a bactéria poderá não ser detectada por técnicas de isolamento e cultivo tradicionais (COLWELL e HUQ, 1994; RUBIN, 2000). No caso de algumas bactérias gram-positivas, esse estado está relacionado à sua esporulação (AMANN et al., 1995; CHOWDHURY et al., 1997; HUQ et al., 2000).

As células microbianas viáveis podem ser parcialmente recuperadas de amostras ambientais complexas por método de plaqueamento convencional, mas ainda não há 
conhecimentos suficientes das condições de crescimento de muitas delas nem como fazer para revertê-las do estado dormente (ROSADO et al., 1997). Atualmente, uma grande fração, geralmente 90-99\%, das células microbianas presentes em amostras ambientais não é cultivável e, portanto, escapará da detecção se métodos baseados em cultivos forem aplicados.

Como mostrado por Morris et al. (2002), o número de trabalhos com o objetivo de conhecer a biodiversidade tem aumentado exponencialmente nos últimos 15 anos, visto que os estudos da diversidade microbiana foram limitados no passado pela falta de ferramentas metodológicas, mas a disponibilidade de novos métodos moleculares torna possível investigar este tópico.

\subsubsection{Identificação direta de comunidades bacterianas}

O estudo da diversidade microbiana em ambientes aquáticos tem chamado a atenção pelo papel que os microrganismos desempenham em ambientes marinhos e de água doce (AZAM et al., 1983; DUCKLOW, 1983; DUCKLOW e CARLSON, 1992; FUHRMAN, 1992; WILLIAMS, 1981b). Para que possamos entender esse papel é importante determinar os números e as concentrações bacterianas em qualquer ambiente. Identificar os fatores primários responsáveis pela regulação dos números bacterianos é o maior objetivo da ecologia microbiana, sendo assim, há a necessidade de se obter o melhor método de análise (KEPNER e PRATT, 1994).

Para determinar a concentração dessas comunidades foram propostos vários métodos que não envolvem o cultivo em laboratório, uma vez que as técnicas microbiológicas tradicionais, como a contagem em placa, são insuficientes para se estudar as comunidades microbianas, sendo este um dos motivos de se conhecer apenas uma pequena fração (entre $<0.1$ a 1\%) dos microrganismos da natureza (AMANN et al., 1995).

Estudos baseados na análise direta da diversidade de comunidades bacterianas no meio ambiente, através do emprego de métodos moleculares, têm revelado um cenário composto por uma rica diversidade de organismos ainda não-cultivados e não estudados em laboratório (WARD et al., 1990; BORNEMAN e TRIPLETT, 1997; KUSKE et al., 1997; LUDWIG et al., 1997; PACE, 1997; HUGENHOLTZ et al., 1998a,b). Dentre estes métodos, as técnicas independentes de cultivo são essenciais para determinar a quantidade dos diferentes tipos de bactérias presentes nas comunidades bacterianas (COTTRELL e KIRCHMAN, 2000a). 
Entre os métodos utilizados para estudar concentração e diversidade microbiana, estão a hibridização com sondas de ácidos nucléicos, além de técnicas de fingerprinting e seqüenciamento, as quais apresentam um melhor custo benefício para observar as diferenças existentes entre as comunidades microbianas (AVANISS-AGHAJANI et al., 1994; FUHRMAN, 2002).

A hibridização com sondas de ácidos nucléicos é rápida e segura quando comparada com os métodos dependentes de cultivo (AMANN et al., 2000). Existem duas técnicas de hibridização básica: a slot ou dot-blot (STAHL et al., 1988; SAHM et al., 1999) e a in situ (DeLONG et al., 1989; AMANN et al., 1990). Ambas são quantitativas e podem ser utilizadas em microrganismos ainda não cultivados. Uma das vantagens da técnica de hibridização in situ é a capacidade de obter informações a respeito da localização das células, da sua distribuição espacial e tamanho, informações essas que são significativas na ecologia microbiana (AMANN et al., 2000).

A hibridização in situ fluorescente (FISH - Fluorescent In Situ Hybridization) usando sondas de 16S rRNA é uma maneira de determinar a composição da comunidade bacteriana sem a utilização da técnica de PCR (Polimerase Chain Reaction) (DeLONG et al., 1989) (Figura 3). Utilizando este método, as células são identificadas por detecção com sondas de oligonucleotídeos marcadas com corantes fluorescentes específicas para diferentes grupos de bactérias.

Desde sua primeira aplicação como corante filogenético em 1989 (DeLONG et al., 1989), a hibridização in situ fluorescente tem se tornado uma ferramenta mundialmente usada para a detecção direta independente de cultivo de células microbianas individuais em amostras ambientais complexas (GLÖCKNER et al., 1999; OLIVEIRA, 2006b).

A contagem de células totais, sem o cultivo tradicional, em amostras de água foi otimizada e está sendo efetuada pela concentração de células em membrana filtrante, uso de corantes específicos para ácidos nucléicos e microscopia epifluorescente (KEPNER e PRATT, 1994). 


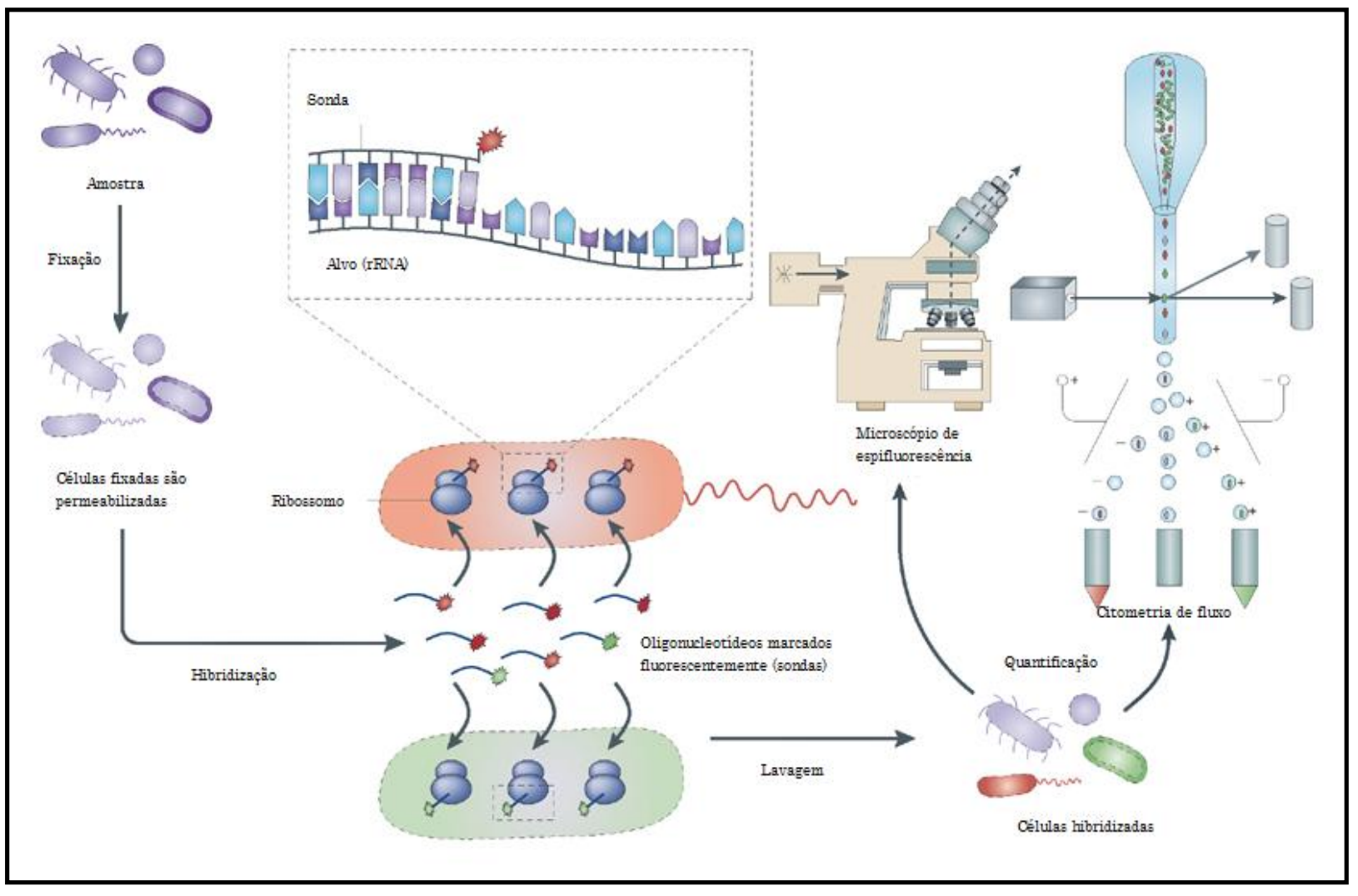

Figura 3 - Passos básicos da hibridização in situ fluorescente. As amostras são fixadas e as sondas de oligonucleotídeos marcadas são adicionadas permitindo a hibridização intracelular. $O$ excesso de sonda é retirado e a amostra está pronta para ser identificada e quantificada em microscópio de epifluorescência ou citômetro de fluxo.

FONTE: adaptado de AMANN e FUCHS, 2008.

A hibridização in situ com sondas de ácidos nucléicos, além de facilitar a identificação de grupos bacterianos e espécies de microrganismos (GLÖCKNER et al., 1996) pode ser utilizada em análise da diversidade microbiana em ambientes naturais, como foi aplicada em amostras de colunas d'água (BRITSCHGI e GIOVANNONI, 1991).

Técnicas epifluorescentes de contagem direta são os métodos mais freqüentes de escolha. É o que dá uma estimativa mais acurada do número total de células, incluindo as não viáveis e as viáveis mas não cultiváveis, nas mais variadas situações (KEPNER e PRATT, 1994). A contagem direta por epifluorescência é o melhor método para a enumeração de bactérias totais em amostras ambientais (BOWDEN, 1977; DALEY, 1979; FRY, 1988; HERBERT, 1990). 


\subsubsection{Análise molecular de comunidades bacterianas}

A identificação e classificação de bactérias são de suma importância nos estudos de ecologia microbiana. Diferentes métodos fenotípicos e genotípicos têm sido empregados para a identificação e classificação microbiana (LOUWS et al., 1996; RADEMAKER et al., 2004a; RADEMAKER e de BRUIJN, 1997; RADEMAKER e SAVELKOUL, 2004; VANDAMME et al., 1996), uma vez que já é sabido que menos de $1 \%$ dos microrganismos encontrados em ambientes aquáticos, sedimentos e solos são recuperados em métodos de cultivos já desenvolvidos (AMANN et al., 1995).

O desenvolvimento de técnicas para recuperar as seqüências de genes de rRNA da natureza permitiu aos pesquisadores identificar organismos em habitats naturais sem a necessidade de cultivá-los (PACE, 1997; HUGENHOLTZ et al., 1998a; ZINDER e SALYERS, 2005). Métodos moleculares baseados em ácidos nucléicos e PCR (genotípicos) têm sido empregados de forma confiável, simples e de baixo custo para identificar e classificar os microrganismos. Estas técnicas consomem menos tempo que as extensas análises fenotípicas e proporcionam resultados mais reprodutíveis (RADEMAKER et al., 2004b).

A aplicação de técnicas baseadas na detecção e análise da diversidade de ácidos nucléicos (DNA ou RNA) presentes em amostras ambientais é fundamental nos estudos de diversidade microbiana, principalmente, por permitir a análise de maneira independente do cultivo das bactérias presentes nas amostras, o que exclui todos os problemas e limitações devido à baixa culturabilidade das comunidades bacterianas. Por outro lado, a biologia molecular pode ser também utilizada de maneira complementar aos dados de isolamento (ANDREOTE, 2007).

O desenvolvimento de métodos para extrair os ácidos nucléicos diretamente de amostras ambientais, os quais podem representar o genoma microbiano, abriu uma nova dimensão para o estudo das comunidades microbianas. A análise do DNA pode fornecer informações da diversidade estrutural de amostras ambientais ou dos microrganismos introduzidos (SMALLA, 2004). 


\subsubsection{Tipagem molecular de bactérias viáveis por rep-PCR}

Estudos recentes têm revelado a existência de uma maior diversidade microbiana do que a esperada em quase todos os ecossistemas estudados. A extensão da diversidade microbiana está ainda em análise (CURTIS et al., 2002) e técnicas moleculares têm permitido a detecção de um número crescente de novos microrganismos (WARD et al., 1990; PACE, 1997; HUGENHOLTZ et al., 1998b; DeLONG, 2001). A técnica básica usada durante as análises moleculares de microrganismos de diversos ambientes naturais é a amplificação pela reação em cadeia pela polimerase (PCR - Polimerase Chain Reaction) de fragmentos de DNA específicos de DNA extraídos de amostras ambientais.

A descoberta da PCR revolucionou as metodologias de fingerprinting. Métodos de tipagem baseados em PCR são capazes de analisar parte ou todo o genoma microbiano. Provavelmente, os métodos de fingerprinting mais discriminatórios usados atualmente são baseados na análise do genoma completo ou seqüenciamento de vários genes (RADEMAKER e de BRUIJN, 1997).

Métodos de fingerprinting baseados em PCR têm muitas vantagens sobre outros métodos moleculares. O método de PCR oferece simplicidade, com diversas utilidades necessitando de menor demanda de instrumentos sofisticados. Com iniciadores apropriados, todo o genoma pode ser amostrado aleatória e uniformemente, gerando fingerprinting robustos sem prejudicar qualquer área específica. Vários estudos têm mostrado que a capacidade discriminativa de métodos de fingerprinting baseados em PCR aborda ou ultrapassa aqueles baseados em ribotipagem e Eletroforese em Gel de Campo Pulsado (PFGE - Pulsed Field Gel Electrophoresis) (SHANGKUAN et al., 1997; MARSHALL et al., 1999; WONG e LIN, 2001).

Vários métodos baseados em PCR, como as técnicas de rep-PCR (REP-PCR, ERICPCR e BOX-PCR) têm sido usadas para gerar análises de fingerprints genômicos. Essas técnicas usam iniciadores que são complementares ao DNA que estão presentes no genoma bacteriano. As seqüências com 35-40 pb são chamadas de Repetitive Extragenic Palindromic (REP), as que possuem 124-127 pb são chamadas de Enterobacterial Repetitive Intergenic Consensus (ERIC) e as que possuem 154 pb são chamadas de BOX. Estas seqüências repetitivas provaram ser úteis ao proporcionar perfil de fingerprinting altamente discriminativo para a maioria dos genomas bacterianos (VERSALOVIC et al., 1991; RADEMAKER et al., 2004b). 
Uma das vantagens do método de fingerprinting genômico rep-PCR é que os fingerprinting podem ser gerados não somente de DNA genômico purificado como também diretamente de células de culturas líquidas ou de colônias em placas e de tecidos de plantas infectados (RADEMAKER e de BRUIJN, 1997; VERSALOVIC et al., 1994; WOODS et al., 1993).

\subsubsection{Análise do gene 16S rDNA}

As limitações dos métodos tradicionais, aliadas ao avanço tecnológico na área de biologia molecular, fazem com que as técnicas moleculares sejam muito utilizadas para o estudo da diversidade microbiana (van ELSAS et al., 1998). Nas últimas décadas, várias metodologias moleculares têm sido desenvolvidas contribuindo significativamente para um grande avanço do conhecimento sobre a variabilidade genética de microrganismos. Dentre as técnicas utilizadas, destacam-se aquelas que utilizam o gene 16S rDNA.

A maioria das técnicas moleculares aplicadas a estudos microbianos baseia-se nas diferenças de composição dos genes ribossomais. Em bactérias, o gene 16S ribossomal (16S rDNA) é o mais utilizado, sendo considerado uma das mais importantes moléculas para o estudo de filogenia e ecologia microbiana (LOUWS et al., 1999).

Sua utilização como marcador filogenético molecular foi proposto por Carl Woese no início da década de 1970 (OLSEN e WOESE, 1993). O ribossomo bacteriano possui uma massa de 2,5 x 106 Da (Dalton) e um coeficiente de sedimentação de 70S (Svedberg), o qual se dissocia em duas subunidades, a subunidade grande (50S) e a subunidade pequena (30S). A subunidade pequena (30S) contém o $16 \mathrm{~S}$ rRNA e 21 proteínas diferentes, enquanto que a subunidade maior (50S) contém o 5S rRNA e o 23S rRNA juntamente com 31 proteínas diferentes (Figura 4) (RODICIO e MENDOZA, 2004). 


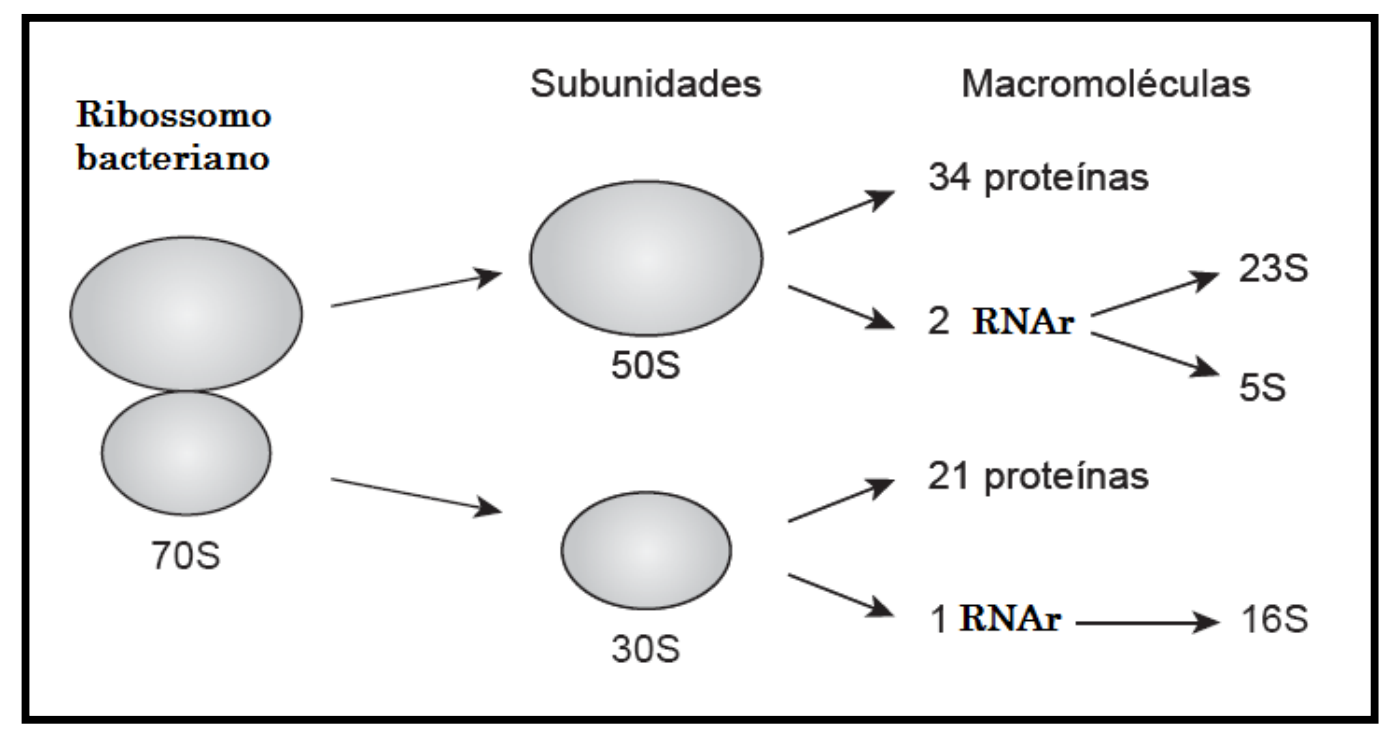

Figura 4 - Esquema da estrutura e indicação das subunidades e macromoléculas do ribossomo bacteriano.

FONTE: adaptado de RODICIO e MENDOZA, 2004.

A estrutura primária do $16 \mathrm{~S}$ rRNA é composta por regiões alternadas de alta e baixa variabilidade. As regiões com seqüências variáveis contêm informação de baixo nível filogenético, enquanto as regiões com seqüências conservadas contêm informação dos eventos evolutivos. Com isso, o RNA ribossomal é um excelente marcador molecular para a reconstrução da maioria das relações filogenéticas (FRY, 1991).

Para a amplificação do $16 \mathrm{~S}$ rRNA, as regiões conservadas facilitam o desenho de oligonucleotídeos iniciadores. Quando se pretende amplificar o gene 16S rDNA completo, utilizam-se iniciadores desenhados com base em sequiências conservadas próximas às extremidades 5' e 3' do gene, que produzem amplificados de aproximadamente $1.500 \mathrm{bp}$. De fato, embora existam posições filogeneticamente informativas ao longo de todo o gene, as maiores variabilidades concentram-se nas primeiras 500 bases nucleotídicas, correspondentes à extremidade 5' (PATEL et al., 2000).

As seqüências de gene $16 \mathrm{~S}$ são consideradas como importantes marcadores moleculares porque estão presentes em todos os organismos, são conservadas estrutural e funcionalmente, apresentam tanto regiões conservadas como variáveis e altamente variáveis em suas estruturas primárias e secundárias (Figura 5), têm um tamanho satisfatório (1.500 nucleotídeos) para fazer inferências filogenéticas, além de apresentarem aparente ausência de transferência gênica horizontal (AMANN e LUDWIG, 2000). 


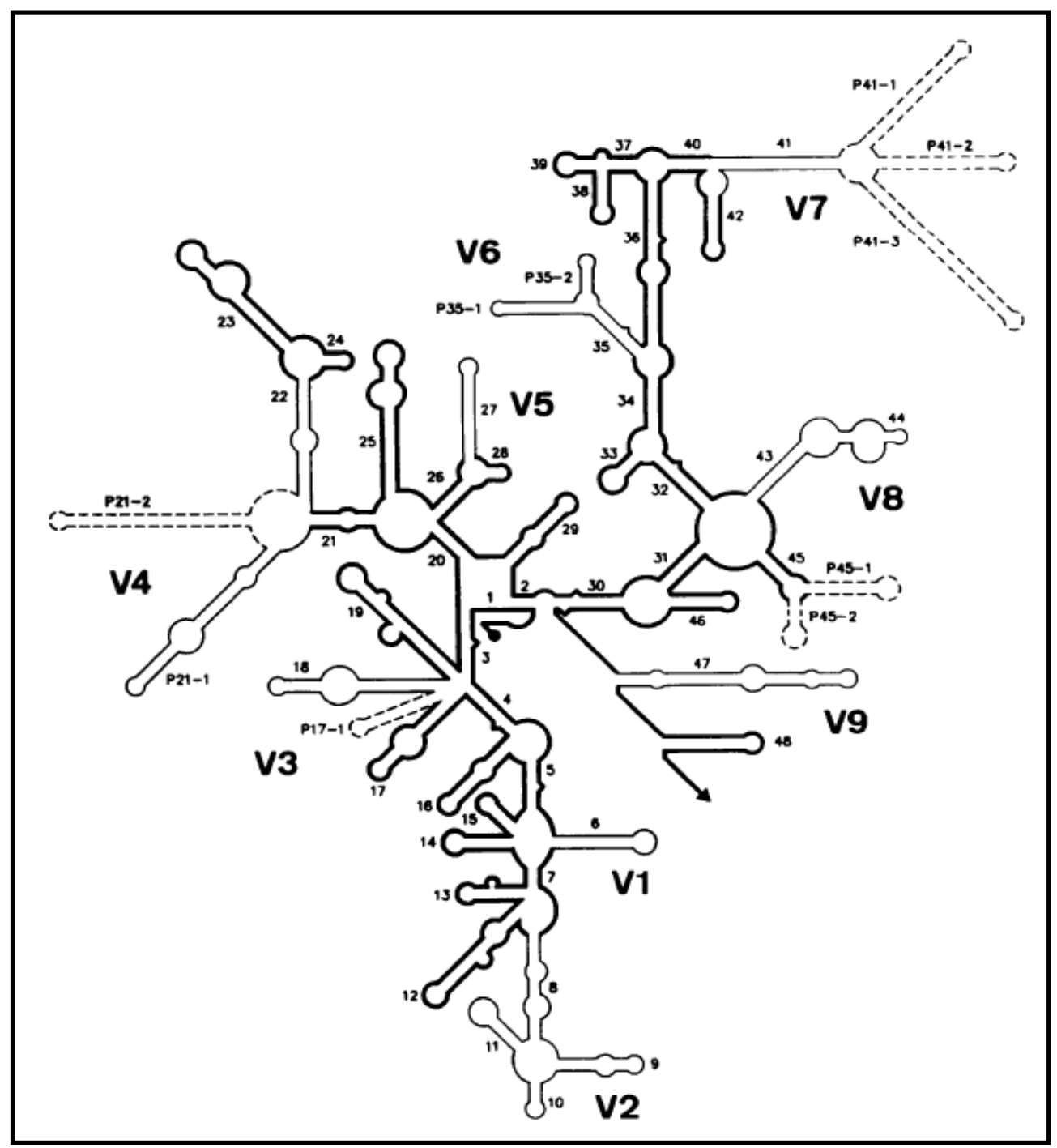

Figura 5 - Estrutura secundária do 16S rRNA. A extremidade 5' é simbolizada por um ponto e a 3' por uma seta. As regiões relativamente conservadas são apresentadas em negrito; as regiões variáveis, em linhas finas (V1-V9, sendo que a V4 é exclusiva de eucariotos); as regiões pontilhadas são as que estão presentes em número limitado de estrutura.

FONTE: NEEFS et al., 1990.

A diversidade bacteriana foi estudada em vários ambientes baseando-se nos genes $16 \mathrm{~S}$ rDNA dos seus componentes, revelando a grande diversidade que deixa de ser explorada quando apenas métodos baseados em cultivo são aplicados (HEAD et al., 1998). Utilizando técnicas independentes de cultivo baseadas em seqüências do gene 16S rDNA foi descrita a comunidade bacteriana do oceano, sendo estimado a presença de valores próximos a 21.000 seqüências diferentes compondo esta comunidade (SOGIN et al., 2006). 
Estas técnicas, usadas mundialmente para estudar a diversidade bacteriana, estão sendo baseadas em bibliotecas de genes 16S rDNA, os quais são obtidos de bactérias usando PCR com seqüências de genes universais de bactérias ou seqüências de genes universais de 16S rDNA (DeLONG et al., 1993; FUHRMAN et al., 1993; GIOVANNONI e RAPPÉ, 2000). O seqüenciamento desse gene permite a identificação de microrganismos em nível de gênero e, possivelmente, em nível de espécie, como também pode permitir correlações entre o genótipo e o ambiente estudado (CHÈNEBY et al., 2000). Entretanto, estão sendo propostos outros genes que podem ajudar no estudo evolutivo e classificação de bactérias, como o rpoA, recA, pyrH (THOMPSON et al., 2005a).

\subsubsection{Construção de bibliotecas genômicas}

A metagenômica, também conhecida como genômica ambiental, surgiu como uma poderosa ferramenta para análise das comunidades microbianas, independentemente da capacidade dos organismos serem cultivados em laboratório. Esta ferramenta é baseada na análise genômica do DNA microbiano extraído diretamente das comunidades em amostras ambientais (COLWELL, 2006).

Com menos de $1 \%$ das bactérias sendo capazes de ser estudadas por métodos clássicos de cultivo, tornou-se óbvio que esta abordagem era insuficiente para caracterizar toda a estrutura da comunidade bacteriana, embora possa identificar alguns membros da comunidade. Por este motivo, alternativas se faziam necessárias (AMANN et al., 1995).

Tais alternativas surgiram na década de 1980, quando estudos da comunidade bacteriana foram possíveis com o desenvolvimento da filogenia molecular, permitindo a classificação dos organismos de acordo com a relação evolutiva mostrado pela sequência de similaridade de moléculas como o RNA ribossomal (WOESE, 1987).

Embora desenvolvido originalmente com cultura pura, a filogenia molecular pode ser aplicada em comunidades naturais após ter sido reconhecido que o ácido nucléico pode ser extraído diretamente amostras de ambientes naturais e os genes de interesse poderiam ser clonados e seqüenciados (OLSEN et al., 1986; PACE et al., 1986). Assim, uma sequência de dados genéticos poderia ser obtida sem a necessidade do cultivo e mesmo que um organismo nunca tenha sido descrito antes, a sequência mostra como ele se relaciona com outros organismos e fornece meios para pelo menos tentar nomeá-lo (FUHRMAN e HAGSTRÖM, 2008). 
A técnica de construção e seqüenciamento de bibliotecas de clones de genes ribossomais é uma ferramenta de alta sensibilidade no estudo de comunidades microbianas que possibilita a comparação de genótipos de microrganismos não cultiváveis que representam 99\% do total de espécies presentes em amostras ambientais (SCHLOSS e HANDELSMAN, 2005).

A construção de bibliotecas genômicas tem sido uma estratégia bastante utilizada no campo da ecologia microbiana (BÉJÁ et al., 2000; KOSDRÓJ e van ELSAS, 2001). Tal estratégia permite que sequiências específicas do 16S rRNA sejam obtidas e possam ser analisadas com o auxílio de programas computacionais, possibilitando assim, a identificação de microrganismos presentes em amostras ambientais (SANZ e KÖCHLING, 2007).

Em essência, as tentativas metagenômicas de analisar o genoma complexo de comunidades microbianas são iniciadas pela obtenção de DNA total do ecossistema (STREIT e SCHMITZ, 2004). Uma maior abordagem do seqüenciamento utilizado para analisar as amostras de água do mar de Sargasso revelou seqüências de DNA nunca antes descritas (VENTER et al., 2004). Com esta consumação, espera-se que novas possibilidades sejam abertas para investigar o mundo microbiano e sua evolução em uma escala nunca antes imaginada. No entanto, novas ferramentas de bioinformática serão necessárias para analisar todas as informações que possam surgir. 


\section{MATERIAL E MÉTODOS}

\subsection{DESCRIÇÃO DA ÁREA DE ESTUDO}

O Canal de São Sebastião está localizado na área central da Margem Continental Sudeste Brasileira, região esta denominada Embaiamento de São Paulo (ZEMBRUSCKI, 1979). Ela se caracteriza pela proximidade da Corrente do Brasil, que flui ao longo do talude continental, transportando massas de água de origens distintas: a massa de Água Tropical e a Água Central do Atlântico Sul. A influência da Água Tropical é predominante na camada de superfície e, nas camadas mais profundas, a Água Central do Atlântico Sul contribui com um volume superior a 50\% do volume total da água da plataforma continental para a formação das massas de água a leste da Ilha de São Sebastião (MIRANDA, 1982; CASTRO FILHO et al., 1987; CASTRO, 1996). Da mistura não isopicnal da Água Tropical e da Água Central do Atlântico Sul com massas de água com influência continental ocorre a geração da massa de Água Costeira (MIRANDA, 1982; CASTRO, 1996).

O Canal tem uma extensão de $25 \mathrm{~km}$ e as entradas possuem configuração afunilada com larguras aproximadas de 7,2 e 5,6 km, sendo que a parte mais estreita, com aproximadamente 1,9 km, está localizada na Ponta do Araçá. A profundidade varia entre 20$25 \mathrm{~m}$ na parte sul e de 10-20 m na parte norte, chegando a uma profundidade máxima de, aproximadamente, $50 \mathrm{~m}$ na parte central do canal, próximo ao Porto de São Sebastião, local que apresenta uma topografia do fundo do oceano com inclinações íngremes (FURTADO, 1995; SILVA, 2001; SILVA et al., 2005).

As características termohalinas da água do mar na região do Canal de São Sebastião estão determinadas pela mistura, em proporções variáveis, da Água Costeira, que apresenta alta temperatura e baixa salinidade $\left(>20^{\circ} \mathrm{C}\right.$ e 32,2 - 35,4\%o), Água Tropical com altos valores de temperatura e salinidade $\left(>20^{\circ} \mathrm{C}\right.$ e $>36,4 \%$ ), Água Central do Atlântico Sul que contém temperatura e salinidade relativamente baixas $\left(<20^{\circ} \mathrm{C}\right.$ e $<36,4 \%$ ), pelo padrão de correntes geradas principalmente pelo vento e as condições climatológicas prevalecentes na região (CASTRO FILHO et al., 1987; CASTRO FILHO, 1990).

O Canal de São Sebastião é um importante porto petrolífero e estância turística, sendo importante ressaltar a sua singularidade na costa brasileira, não só devido às suas dimensões físicas, mas também por não ser um canal estuarino, o que torna a sua oceanografia física 
bastante específica (GORNI e WEBER, 2004). A fauna bêntica e sua distribuição foi descrita por Pires-Vanin et al. (1997).

A região do Canal de São Sebastião é de grande importância econômica e social, não somente por seus recursos naturais, mas também pela localização de centros urbanos, área de lazer, atividades pesqueiras, e por conter um dos mais importantes terminais petrolífero do país, o Terminal Almirante Barroso (TEBAR). Além do terminal, o Canal de São Sebastião abriga instalações portuárias, como a do Porto de São Sebastião e nele ainda desembocam quatro emissários submarinos, dos sete que há no Estado de São Paulo (MENDES, 2007).

Dos quatro emissários submarinos localizados no Canal de São Sebastião, três são para lançamento de esgotos domésticos (Saco da Capela, Araçá, Cigarras) e um (TASSE Terminal Aquaviário de São Sebastião / Petrobrás) é para lançamento de efluentes líquidos gerados na drenagem dos fundos dos tanques de petróleo e de navios, águas pluviais e industriais contaminadas com óleo (COMPANHIA DE TECNOLOGIA DE SANEAMENTO AMBIENTAL - CETESB, 2008).

O principal emissário submarino, o do Araçá, está localizado na Praia do Araçá, com um ponto de difusão a 8 metros de profundidade em um local onde as correntes do Canal são de baixa intensidade. A rápida expansão do turismo e condomínios nos últimos dez anos e a presença do terminal petrolífero também contribuíram para intensificar as descargas de esgotos domésticos e industriais para a área do Canal (CETESB, 2008).

\subsection{PERÍOdo DE AMOSTRAgem E PONTOS DE COLETA DE AMOSTRAS DE ÁGUA}

Entre agosto de 2005 a março de 2007, 5 litros de amostras de água do mar foram coletadas a $10 \mathrm{~cm}$ da superfície em dois pontos determinados pelo sistema de posicionamento global, GPS 38 (Garmin), no Canal de São Sebastião, litoral norte do Estado de São Paulo. Através deste sistema, o Ponto 1 (Lat $23^{\circ} 49^{\prime} 50^{\prime}$ 'S, Long $45^{\circ} 25^{\prime} 20^{\prime}$ 'W) foi fixo em frente à praia do Segredo, onde se encontra o Centro de Biologia Marinha (CEBIMar) e o Ponto 2 (Lat $23^{\circ} 49^{\prime} 56^{\prime}$ 'S, Long 4525'51' 'W) na região norte da praia de Barequeçaba (Figura 6). As

amostras foram coletadas em frascos de polipropileno previamente esterilizados. Após a coleta, foram transportadas, sob refrigeração, para o Laboratório de Microbiologia Ambiental/ICB II/USP e analisadas no prazo máximo de 24 horas. 


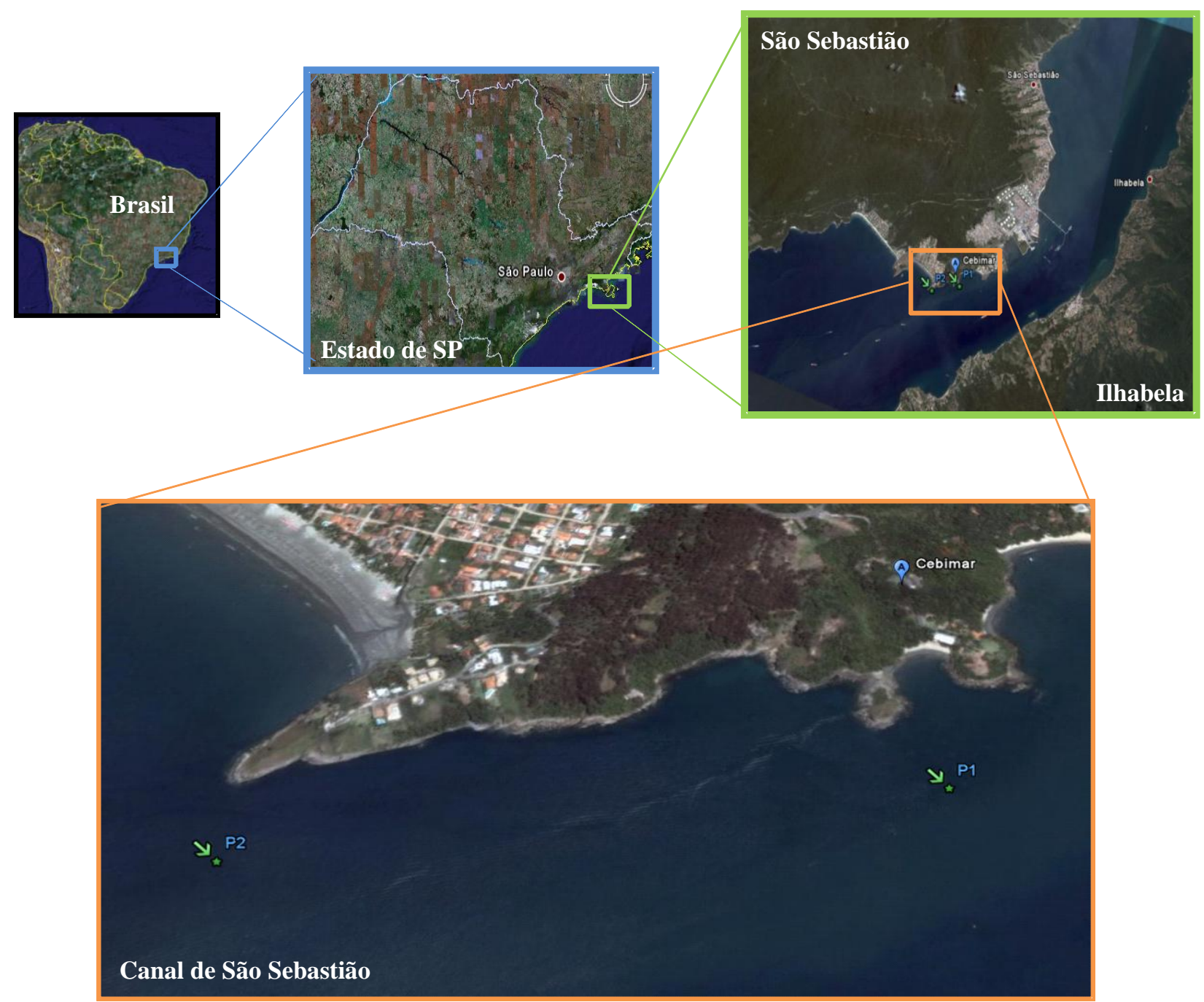

Figura 6 - Localização dos pontos de coleta no Canal de São Sebastião.

FONTE: Google Earth.

\subsection{CARACTERIZAÇÃO FÍSICO-QUÍMICA DAS AMOSTRAS DE ÁGUA DO MAR}

Os dados de parâmetros físico-químicos do local de estudo (temperatura da água do mar, temperatura do ambiente, salinidade, condutividade, $\mathrm{pH}$, oxigênio dissolvido, umidade relativa do ar, posição dos ventos e correntes marítimas) foram cedidos pelo Centro de Biologia Marinha / USP, o qual possui um banco de dados com esses parâmetros que são medidos diariamente por uma estação meteorológica e/ou manualmente pelos funcionários. 


\subsection{CARACTERIZAÇÃo MICROBIOLÓgICA DAS AMOSTRAS DE ÁGUA DO} MAR

Antes de iniciarmos a descrição dos métodos utilizados para analisar as amostras de água do mar, cabe explicar que este trabalho foi dividido em duas etapas: a primeira, compreende a parte da análise das bactérias cultiváveis encontradas nas amostras de água do mar, com ênfase nas classes $\alpha$-, $\beta$-, $\gamma$ - e $\delta$-proteobacteria, usando as técnicas de rep-PCR e seqüenciamento da região $16 \mathrm{~S}$ rRNA e a segunda, a parte da quantificação dos grupos $\alpha$-, $\beta$-, $\gamma$ - e $\delta$-proteobacteria pela técnica de hibridização in situ (FISH) e da análise da diversidade total da amostra de água do mar através da construção de bibliotecas genômicas. Um fluxograma foi feito para fins de melhor visualização e entendimento das etapas metodológicas realizadas (Figura 7).

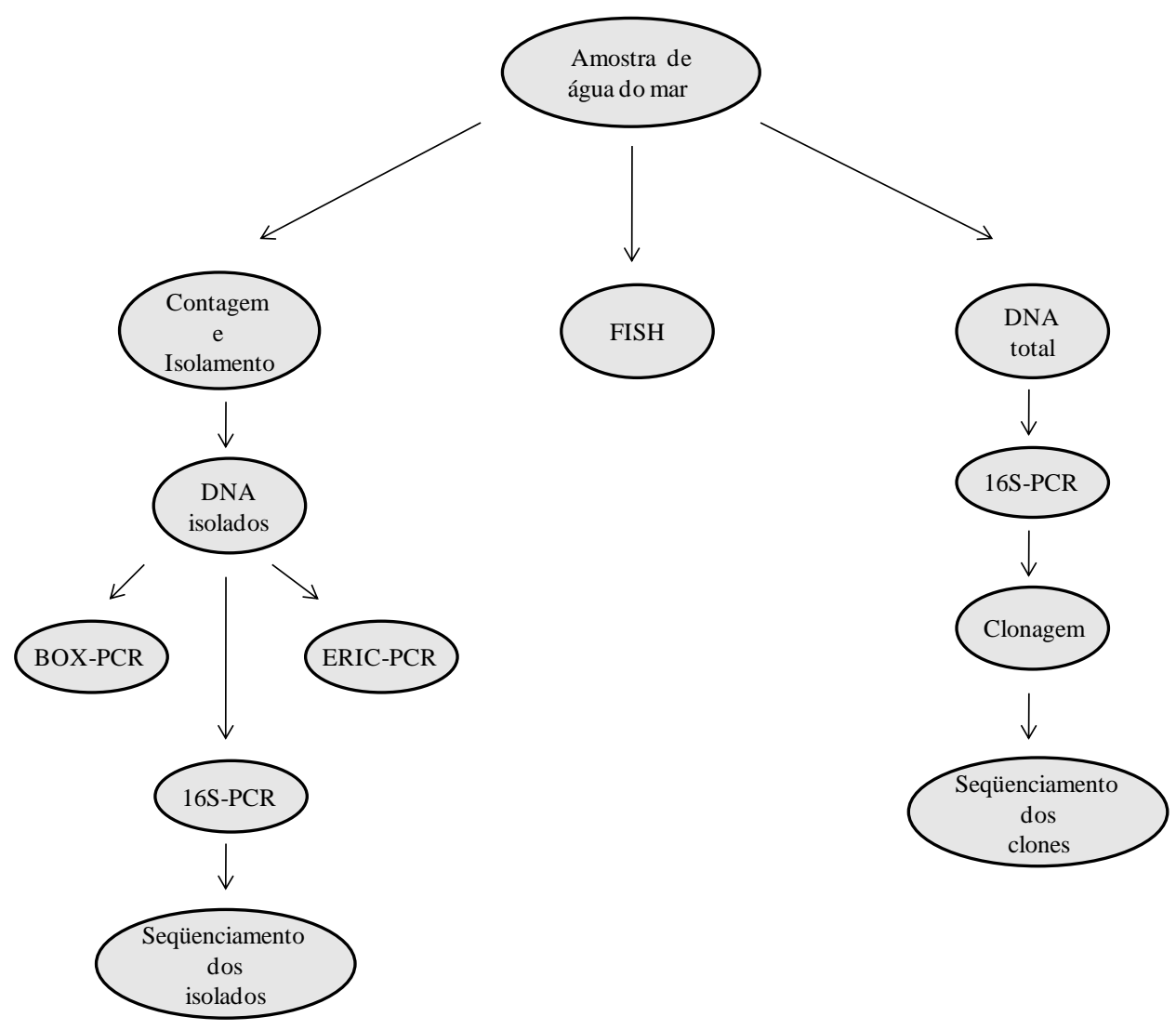

Figura 7 - Fluxograma mostrando as etapas de trabalho e esquematização de como os resultados serão apresentados no decorrer deste estudo. 


\subsubsection{Contagem e isolamento de bactérias marinhas}

Bactérias marinhas viáveis (BMV) foram quantificadas nas amostras de água do mar através da inoculação de 0,05 mL e 0,1 mL da amostra, previamente homogeneizada, em uma placa de petri contendo o meio Agar Marinho (2216, Difco) e espalhados com a alça de vidro, segundo a técnica de semeadura em superfície (Spread Plate). As placas foram incubadas a 25 ${ }^{\circ} \mathrm{C} \pm 2{ }^{\circ} \mathrm{C} / 24-48 \mathrm{~h}$ (AMERICAN PUBLIC HEALTH ASSOCIATION - APHA, 2005). As análises foram feitas em triplicatas para cada um dos volumes inoculados.

Após o período de incubação, foi efetuada a contagem das colônias e, aproximadamente, 5 colônias de cada placa foram selecionadas aleatoriamente e semeadas em tubos de ensaio contendo o meio Agar Marinho inclinado, os quais foram estocados à temperatura ambiente para uso imediato e a $-80{ }^{\circ} \mathrm{C}$ em glicerol a $30 \%$ para uso a longo prazo. Os resultados das contagens de colônias nas amostras de água do mar foram expressos em UFC (Unidades Formadoras de Colônias)/mL. Posteriormente, todos as bactérias marinhas foram submetidos à coloração de Gram e ao teste de KOH (BUCK, 1982). Este último foi feito para confirmar o resultado da coloração de Gram.

\subsubsection{Outras determinações}

Paralelamente às quantificações de bactérias marinhas viáveis, foram realizadas as contagens de Coliformes Termotolerantes (CT), Escherichia coli e Enterococos intestinais (EI) para avaliar a qualidade microbiológica das amostras de água utilizando a metodologia descrita pela APHA (1998).

\subsection{CARACTERIZAÇÃO MOLECULAR DOS ISOLADOS DE BACTÉRIAS MARINHAS}

\subsubsection{Extração do DNA genômico}

A extração do DNA genômico das bactérias marinhas foi feita utilizando o Kit

Wizard $^{\circledR}$ Genomic DNA Purification (A1125, Promega Co., EUA) de acordo com as instruções do fabricante. 
A qualidade e concentração do DNA de cada amostra foi determinada através de eletroforese em gel de agarose $0,8 \%$ (p/v) em tampão TAE 1X (Anexo A1) e por dosagem espectrofotométrica à razão O.D. $260 \mathrm{~nm} / 280 \mathrm{~nm}$ em um aparelho NanoDrop® ND-1000 (Thermo Scientific). Foram aplicados nos poços do gel $5 \mu \mathrm{L}$ do marcador de peso molecular (DNA do fago $\lambda$ digerido com Hind III - Promega) e $2 \mu \mathrm{L}$ das amostras de DNA adicionado com $2 \mu \mathrm{L}$ de tampão TE (Anexo A2) e $1 \mu \mathrm{L}$ de corante azul de bromofenol. Após a corrida, o gel foi corado com solução de Brometo de Etídeo $(0,5 \mu \mathrm{g} / \mathrm{mL})$ por 10 minutos. O resultado do gel foi documentado e fotografado sob luz ultravioleta em fotodocumentador modelo GEL DOC XR System (Bio-Rad).

\subsubsection{Tipagem molecular utilizando os métodos BOX-PCR e ERIC-PCR}

\subsubsection{BOX-PCR}

Os DNAs de bactérias marinhas viáveis foram amplificados através da técnica de BOX-PCR (Reação em cadeia pela Polimerase utilizando seqüências Modulares Repetitivas) utilizando o iniciador BOX A1R (5' CTA CGG CAA GGC GAC GCT GAC G 3') de acordo com Versalovic et al. (1991), com modificações nas condições de amplificação.

A reação de amplificação consistiu na concentração de $1 \mathrm{X}$ da solução tampão (1,5 mM de $\mathrm{MgCl}_{2}$ ) (Promega), 0,2 $\mathrm{mM}$ de dNTPs (Promega), 1,6 $\mu \mathrm{M}$ de oligonucleotídeo (Invitrogen), 0,625 U da enzima GoTaq polimerase (Promega) e $4 \mathrm{ng} / \mu \mathrm{L}$ de DNA em volume final de $25 \mu \mathrm{L}$.

As amplificações das bactérias marinhas foram realizadas segundo as seguintes condições: desnaturação inicial a $94{ }^{\circ} \mathrm{C}$ por 5 minutos, seguindo-se 35 ciclos de amplificação consistindo de desnaturação a $94{ }^{\circ} \mathrm{C}$ por 1 minuto, anelamento a $55^{\circ} \mathrm{C}$ por 1 minuto, extensão a $72{ }^{\circ} \mathrm{C}$ por 3 minutos e uma extensão final a $72{ }^{\circ} \mathrm{C}$ por 15 minutos em termociclador (Mastercycler ep Gradient S - Eppendorf).

Como controles positivos foram utilizadas as cepas padrão RC 11 (Vibrio cholerae O1), RC 230 (V. cholerae O1 Inaba), RC 231(V. cholerae O1 Inaba) e 569 B (V. cholerae O1) em todas as reações de PCRs e como controle negativo foi utilizada água ultrapura em lugar do DNA. 


\subsubsection{ERIC-PCR}

Os DNAs das bactérias marinhas também foram amplificados através da técnica de ERIC-PCR (Enterobacterial Repetitive Intergenic Consensus - Polymerase Chain Reaction) utilizando somente o iniciador ERIC 2 (5' AAG TAA GTG ACT GGG GTG AGC G 3'), descrito por Versalovic et al. (1991), com modificações nas condições de amplificação e na utilização de um único iniciador.

A reação de amplificação foi preparada conforme a reação para BOX-PCR e as condições de amplificação foram as seguintes: desnaturação inicial a $95{ }^{\circ} \mathrm{C}$ por 5 minutos, seguindo-se 30 ciclos de amplificação consistindo de desnaturação a $92{ }^{\circ} \mathrm{C}$ por 45 segundos, anelamento a $54{ }^{\circ} \mathrm{C}$ por 1 minuto, extensão a $70{ }^{\circ} \mathrm{C}$ por 10 minutos e uma extensão final a 70 ${ }^{\circ} \mathrm{C}$ por 20 minutos termociclador (Mastercycler ep Gradient $\mathrm{S}$ - Eppendorf).

Os controles, positivo e negativo, foram os mesmos usados na técnica de BOX-PCR.

\subsubsection{Verificação dos amplicons gerados pelas técnicas de BOX-PCR e ERIC-PCR}

A verificação dos produtos amplificados foi realizada em gel de agarose $1 \%(\mathrm{p} / \mathrm{v})$ em tampão TAE 1X. Foram aplicados nos poços do gel $5 \mu \mathrm{L}$ do marcador de peso molecular (DNA do fago $\lambda$ digerido com Hind III - Promega) e $15 \mu \mathrm{L}$ dos produtos amplificados adicionado de $3 \mu \mathrm{L}$ de corante azul de bromofenol. Após a corrida, o gel foi corado com solução de Brometo de Etídeo $(0,5 \mu \mathrm{g} / \mathrm{mL})$ por 10 minutos. O resultado do gel foi documentado e fotografado sob luz ultravioleta em fotodocumentador modelo GEL DOC XR System (Bio-Rad).

\subsubsection{Seqüenciamento parcial da região 16S rRNA dos isolados bacterianos}

\subsubsection{Amplificação da região 16S rRNA}

A amplificação do gene 16S rDNA das bactérias marinhas foi realizada utilizando os iniciadores 27F (5' AGA GTT TGA TCM TGG CTC AG 3') (LANE, 1991) e 1041R (5' CGG TGT GTA CAA GAC CC 3') (NUBEL et al., 1996), onde M indica A ou C.

As reações foram feitas em um volume final de $100 \mu \mathrm{L}$, sendo $1 \mathrm{X}$ de solução tampão (Invitrogen), 1,5 $\mathrm{mM}$ de $\mathrm{MgCl}_{2}$ (Invitrogen), 0,008 $\mathrm{mM}$ de dNTPs (Invitrogen), 0,4 $\mu \mathrm{M}$ de cada iniciador (Invitrogen), $2 \mathrm{U}$ da enzima Taq polimerase (Invitrogen) e $1 \mathrm{ng} / \mu \mathrm{L}$ de DNA. 
Em todas as reações foi utilizado o DNA de Escherichia coli (ATCC 25922) como controle positivo e água ultrapura, em substituição ao DNA, como controle negativo.

A reação de amplificação foi realizada segundo as seguintes condições: desnaturação inicial a $95{ }^{\circ} \mathrm{C}$ por 2 minutos, seguindo-se 30 ciclos de amplificação consistindo de desnaturação a $94{ }^{\circ} \mathrm{C}$ por 2 minutos, anelamento a $55^{\circ} \mathrm{C}$ por 1 minuto, extensão a $72{ }^{\circ} \mathrm{C}$ por 3 minutos e uma extensão final a $72{ }^{\circ} \mathrm{C}$ por 10 minutos em termociclador (Mastercycler ep Gradient S - Eppendorf).

O fragmento de DNA amplificado $(1 \mu \mathrm{L})$ foi visualizado por eletroforese em gel de agarose $1 \%(\mathrm{p} / \mathrm{v})$ em tampão TAE $1 \mathrm{X}$, juntamente com $5 \mu \mathrm{L}$ do marcador de peso molecular $1 \mathrm{~Kb}$ Plus DNA Ladder (Invitrogen). O gel foi corado em solução de Brometo de etídio (0,5 $\mathrm{ug} / \mathrm{mL}$ ) por 10 minutos e fotografado em fotodocumentador modelo GEL DOC XR System (Bio-Rad).

\subsubsection{Preparação das amostras para seqüienciamento}

Os amplicons do gene $16 \mathrm{~S}$ rDNA foram purificados com o Kit Ilustra GFX ${ }^{\mathrm{TM}} P C R$ DNA and Gel Band Purification (28-9034-70, GE Healthcare) e eluídos em $30 \mu \mathrm{L}$ de água ultrapura, seguindo as instruções do fabricante. Após purificação, $1 \mu \mathrm{L}$ do produto purificado foi visualizado em gel de agarose $1 \%$ (p/v) em tampão TAE $1 X$, juntamente com $2 \mu \mathrm{L}$ do marcador de peso molecular Low DNA Mass Ladder (Invitrogen) e quantificado por dosagem espectrofotométrica em um aparelho NanoDrop® ND-1000 (Thermo Scientific). O gel foi corado em solução de Brometo de etídio $(0,5 \mathrm{ug} / \mathrm{mL})$ por 10 minutos e visualizado em fotodocumentador modelo GEL DOC XR System (Bio-Rad).

\subsubsection{Seqüenciamento parcial da região 16S rRNA}

Para o seqüenciamento, foi preparada uma reação com $4 \mu \mathrm{L}$ (80 ng) do produto purificado e $1 \mu \mathrm{L}$ do iniciador $(5 \mu \mathrm{M})$ 1041R (5' CGG TGT GTA CAA GAC CC 3') (NUBEL et al., 1996) para volume final de $10 \mu \mathrm{L}$ com o DYEnamic ET Dye Terminator Cycle Sequencing Kit for MegaBace DNA Analysis Systems (GE Healthcare) conforme instruções do fabricante e protocolo utilizado no Centro do Genoma Humano/USP. Os produtos foram seqüenciados no seqüenciador automático MegaBace 1000 DNA Analysis System (Amersham Life Biosciences) com as seguintes condições: 30 ciclos de amplificação consistindo de 
desnaturação a $95^{\circ} \mathrm{C}$ por 20 segundos, anelamento a $55^{\circ} \mathrm{C}$ por 15 segundos, extensão a $60{ }^{\circ} \mathrm{C}$ por 1 minuto e uma extensão final a $10^{\circ} \mathrm{C}$, no Centro do Genoma Humano/USP.

\subsection{DETERMINAÇÃO DA CONCENTRAÇÃO BACTERIANA PELA TÉCNICA DE HIBRIDIZAÇÃO in situ FLUORESCENTE (FISH)}

\subsubsection{Conservação das amostras de água}

Para a manutenção da integridade morfológica das células, foram retirados $10 \mathrm{~mL}$ de água dos frascos de amostras coletadas, após agitação, e transferidos para tubos do tipo Falcon com volume total para $15 \mathrm{~mL}$ contendo paraformaldeído 4\% (Merck KGaA, Germany) para a fixação das mesmas. Os frascos foram armazenados ao abrigo da luz até o momento da análise.

\subsubsection{Preparo das sondas fluorescentes}

Foram utilizadas quatro sondas de oligonucleotídeos marcadas com Cy3 (Cyanine 3) e duas sequiências de oligonucleotídeos competidoras não marcadas para as classes Alpha-, Beta-, Gamma- e Delta-Proteobacteria (Tabela 2).

Tabela 2 - Sondas utilizadas para a contagem de grupos bacterianos usando a técnica de hibridização in situ fluorescente (FISH).

\begin{tabular}{|c|c|c|c|c|c|}
\hline Sonda & Especificidade & Sequência da sonda (5' - 3') & $\begin{array}{c}\text { Local marcado }^{\text {b }} \\
\text { (posição no rRNA) }\end{array}$ & $\% \mathbf{F A}^{\mathrm{c}}$ & Referência \\
\hline ALF1b & Subclasse Alphap roteobacteria & CGT TCG YTC TGA GCC AG ${ }^{a}$ & $16 \mathrm{~S}(19-35)$ & 30 & MANZ et al. , 1992 \\
\hline BET42a & Subclasse Betaproteobacteria & GCC TTC CCA CTT CGT TT & $23 S(1027-1043)$ & 30 & MANZ et al. , 1992 \\
\hline GAM42a & Subclasse Gammaproteobacteria & GCC TTC CCA CAT CGT TT & $23 S(1027-1043)$ & 30 & MANZ et al. , 1992 \\
\hline DELTA & Subclasse Deltap roteobacteria & CGG CGT CGC TGC GTC AGG & $16 \mathrm{~S}(385-402)$ & 20 & AMANN et al ., 1995 \\
\hline BET42a & Subclasse Betaproteobacteria & GCC TTC CCA CTT CGT TT & -- & 30 & MANZ et al. , 1992 \\
\hline GAM42a & Subclasse Gammaproteobacteria & GCC TTC CCA CAT CGT TT & -- & 30 & MANZ et al., 1992 \\
\hline
\end{tabular}


As sondas, sintetizadas em uma escala de $50 \mathrm{nmol}$ (Operon Biotechnologies, Inc.), foram ressuspensas em solução tampão TE $1 \mathrm{M}$ - $\mathrm{pH} 7.0$ (Anexo A2), conforme recomendações do fabricante. Foi feita uma solução estoque a uma concentração de 250 $\mathrm{ng} / \mu \mathrm{L}$ e, desta foi preparada a solução de trabalho a uma concentração de $25 \mathrm{ng} / \mu \mathrm{L}$.

No momento do uso, as sondas foram preparadas da seguinte maneira: (1) ALF1b: em um tubo eppendorf com volume total para $0,5 \mathrm{~mL}$ colocou-se $30 \mu \mathrm{L}$ da sonda marcada com Cy3 $(25 \mathrm{ng} / \mu \mathrm{L}$ ) e adicionou-se $270 \mu \mathrm{L}$ de solução de hibridização filtrada (Anexo A3) em membrana de éster celulose de 0,22 $\mu \mathrm{m}$ de porosidade e $25 \mathrm{~mm}$ de diâmetro (GSWP 02500, Millipore, Corp.); (2) BET42a: em um tubo eppendorf com volume total para 0,5 mL colocou-se $15 \mu \mathrm{L}$ da sonda marcada com Cy3 (25 ng/ $\mu \mathrm{L})$ e $15 \mu \mathrm{L}$ da sonda GAM42a competidora sem marcação ( $25 \mathrm{ng} / \mu \mathrm{L}$ ) e adicionou-se $270 \mu \mathrm{L}$ de solução de hibridização; (3) GAM42a: em um tubo eppendorf com volume total para $0,5 \mathrm{~mL}$ colocou-se $15 \mu \mathrm{L}$ da sonda marcada com Cy3 $(25 \mathrm{ng} / \mu \mathrm{L})$ e $15 \mu \mathrm{L}$ da sonda BET42a competidora sem marcação (25 ng/ $\mu \mathrm{L}$ ) e adicionou-se $270 \mu \mathrm{L}$ de solução de hibridização; (4) DELTA: em um tubo eppendorf com volume total para 0,5 mL colocou-se $30 \mu \mathrm{L}$ da sonda marcada com Cy3 $(25 \mathrm{ng} / \mu \mathrm{L})$ e adicionou-se $270 \mu \mathrm{L}$ de solução de hibridização (GLÖCKNER et al., 1996).

\subsubsection{Hibridização in situ fluorescente e contagem direta de células pela técnica de microscopia}

A hibridização in situ das bactérias dos grupos $\alpha$-, $\beta$-, $\gamma$ - e $\delta$-proteobacteria através de sondas específicas foi determinada conforme metodologia descrita por Glöckner et al. (1996), com modificações. Um volume de $0,5 \mathrm{~mL}$ das amostras pré-fixadas com $4 \%$ de paraformaldeído (Merck KGaA, Germany) foram filtradas utilizando membrana branca de policarbonato de 0,22 $\mu \mathrm{m}$ de porosidade e $25 \mathrm{~mm}$ de diâmetro (23007-25 N, Sartorius AG, Germany) com o auxílio de seringas e suporte de filtros (SX00 02500 Swinnex, Millipore, Corp.). Em seguida, a membrana foi lavada duas vezes com água ultrapura no próprio suporte. As membranas foram retiradas do suporte de filtro e cortadas em quatro partes iguais. Cada uma delas foi colocada numa lâmina de vidro, previamente coberta com parafilme e, 40 $\mu \mathrm{L}$ das sondas específicas foram retiradas das soluções de trabalho (item 4.6.2).

Posteriormente, adicionou-se $10 \mu \mathrm{L}$ de cada sonda em suas respectivas lâminas, onde foram adicionados os respectivos pedaços de membrana e adicionou-se $30 \mu \mathrm{L}$ das sondas pesquisadas sobre cada pedaço desta membrana. As lâminas foram, então, colocadas em tubos 
do tipo Falcon com volume total para $50 \mathrm{~mL}$ (câmaras de hibridização), contendo um pedaço de lenço de papel retorcido no fundo saturado com $2 \mathrm{~mL}$ de solução de hibridização. Os tubos foram fechados e incubados a $42{ }^{\circ} \mathrm{C}$ por 4 horas.

As membranas foram colocadas dentro de placas de polipropileno com cavidades (92006, TPP AG, Switzerland) contendo solução de lavagem (Anexo A4) pré-aquecida a 48 ${ }^{\circ} \mathrm{C}$ e incubadas a $48{ }^{\circ} \mathrm{C}$ por 15 minutos sem agitação. Após incubação, a solução de lavagem foi retirada e as membranas colocadas sobre uma lâmina de vidro até a completa secagem. Finalmente, $100 \mu \mathrm{L}$ de 4',6-diamidino-2-phenylindole dihydrochloride - DAPI (2 $\mu \mathrm{g} / \mathrm{mL}$; D9542, Sigma-Aldrich Co., EUA) foi adicionado sobre cada pedaço de membrana e incubadas a temperatura ambiente, ao abrigo da luz, durante 5 minutos.

O excesso de corante foi retirado lavando-se as membranas 3 vezes em solução de etanol $80 \%$ e colocando-as sobre uma lâmina e lamínula previamente limpas e secas, com uma gota de óleo de imersão não-fluorescente (Type DF - Cargille Laboratories Inc., USA) e lacrada com esmalte incolor. As lâminas foram estocadas ao abrigo da luz e mantidas refrigeradas $\left(4{ }^{\circ} \mathrm{C}\right)$ até o momento de sua leitura que foi realizada em microscópio de epifluorescência (AXIOVERT 200 MAT) equipado com uma câmera AxioCam HRC (Carl Zeiss Inc., Germany) e com o auxílio de filtros ultravioleta (conjunto de filtros 02 e 20).

Para o cálculo da concentração de células dos quatro grupos bacterianos e das células totais foram contados 20 campos aleatórios da membrana ou até completar 300 células por lâminas com o aumento de 1000 x. O número total de células $\left(\mathrm{N}_{\mathrm{t}}\right)$ foi dividido pelo número de campos contados $\left(\mathrm{N}_{\mathrm{c}}\right)$, assim obteve-se o número médio de células por campo (n). Esse valor médio encontrado foi multiplicado pela área da membrana (A) e dividido pela área do campo de visão (a) e o volume filtrado (V) e, o resultado foi multiplicado por 4 já que o filtro foi cortado em quatro partes e, assim, obteve-se a concentração em células/mL (Figura 8). 


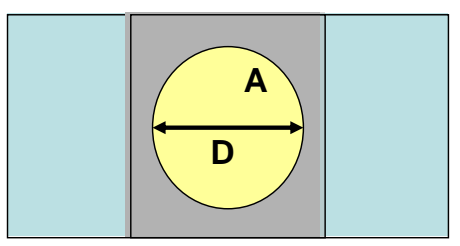

$\mathbf{A}=$ Área da membrana $\left(\mathrm{mm}^{2}\right)$

$\mathbf{V}=$ Volume filtrado $(\mathrm{mL})$

Concentração $=\left[\frac{\mathrm{n} \times \mathrm{A}}{\mathrm{V} \times \mathrm{a}}\right] \times 4 \quad$ (células $\left./ \mathrm{mL}\right)$

Figura 8 - Cálculo da concentração bacteriana total e dos grupos $\alpha$-, $\beta$-, $\gamma$ - e $\delta$-proteobacteria. A: $490,6 \mathrm{~mm}^{2} ;$ a: $0,0283 \mathrm{~mm}^{2} ; \mathbf{n}: \mathrm{N}_{\mathrm{t}}$ (número total de células contadas) / $\mathrm{N}_{\mathrm{c}}$ (número total de campos contados); D: diâmetro da membrana; d: diâmetro do campo de visão.

\subsection{CARACTERIZAÇÃO MOLECULAR DAS POPULAÇÕES BACTERIANAS: CONSTRUÇÃO DE BIBLIOTECAS DO GENE 16S rDNA}

\subsubsection{Preparação das amostras de água}

Para a extração do DNA total, $250 \mathrm{~mL}$ de água do mar foram retirados dos frascos de amostras coletadas, após agitação, e filtrados pela técnica da membrana filtrante usando membrana de policarbonato de 0,22 $\mu \mathrm{m}$ de porosidade e $47 \mathrm{~mm}$ de diâmetro (GTTP 04700, Millipore, Corp.). As membranas foram lavadas duas vezes com água de diluição (Anexo A5) para retirar o excesso de sal e armazenadas à $-20^{\circ} \mathrm{C}$ até o momento da análise.

\subsubsection{Extração do DNA total das amostras de água do mar}

A extração do DNA total foi feita segundo Rivera et al. (2003) com modificações. As membranas foram cortadas em pedaços pequenos, assepticamente, e colocadas em tubos de centrífuga, onde foram suspensas em 1,8 mL de tampão SET (Anexo A6) adicionados de 360 $\mu \mathrm{L}$ de solução de lisozima $(5 \mathrm{mg} / \mathrm{mL})$. As amostras foram incubadas a $37^{\circ} \mathrm{C}$ por 1 hora, em banho-maria, sob agitação a cada 10 minutos. Em seguida, foram adicionados $115 \mu \mathrm{L}$ de solução de SDS $10 \%$ e $25 \mu \mathrm{L}$ de uma solução de proteinase $\mathrm{K}(20 \mathrm{mg} / \mathrm{mL})$ com nova 
incubação a $37{ }^{\circ} \mathrm{C}$ por 1 hora. Após esta segunda incubação, adicionou-se 0,5 $\mu \mathrm{L}$ de uma solução de RNAse $(20 \mathrm{mg} / \mathrm{mL})$ e deixou durante 1 hora, sob agitação constante a $37^{\circ} \mathrm{C}$.

Procedeu-se a extração através da adição de $400 \mu \mathrm{L}$ de $\mathrm{NaCl} 5 \mathrm{M}$ e $280 \mu \mathrm{L}$ de solução CTAB $10 \%$ pré-aquecida a $65^{\circ} \mathrm{C}$. Os tubos foram incubados por 20 minutos a $65^{\circ} \mathrm{C}$ com agitação constante. Aos tubos de extração adicionou-se igual volume ( $3 \mathrm{~mL})$ da mistura de fenol-clorofórmio-álcool isoamílico (25:24:1), os quais foram agitados e centrifugados a 10.000 r.p.m. por 10 minutos à temperatura ambiente para separação das fases.

A fase aquosa foi transferida para outro tubo de centrífuga e purificado com igual volume da mistura clorofórmio-álcool isoamílico (24:1) sob centrifugação a 10.000 r.p.m. por 10 minutos à temperatura ambiente. $\mathrm{O}$ sobrenadante foi transferido para um tubo de vidro para a precipitação do DNA com 0,6 volume de isopropanol. O precipitado foi coletado por centrifugação a 10.000 r.p.m. por 10 minutos e lavado com etanol 70\% gelado. Após a secagem, o DNA foi suspenso em $50 \mu \mathrm{L}$ de água ultrapura e estocado a $4{ }^{\circ} \mathrm{C}$.

A qualidade do DNA total extraído foi verificada através de eletroforese em gel de agarose $0,8 \%(\mathrm{p} / \mathrm{v})$ em tampão TAE $1 \mathrm{X}$ e a concentração foi determinada por espectrofotometria em um aparelho NanoDrop® ND-1000 (Thermo Scientific). Foram aplicados nos poços do gel $5 \mu \mathrm{L}$ do marcador de peso molecular (DNA do fago $\lambda$ digerido com Hind III - Promega) e $1 \mu \mathrm{L}$ das amostras de DNA adicionadas de $1 \mu \mathrm{L}$ de corante azul de bromofenol. O gel foi corado com solução de Brometo de Etídeo $(0,5 \mu \mathrm{g} / \mathrm{mL})$ por 10 minutos e fotografado em fotodocumentador modelo GEL DOC XR System (Bio-Rad).

\subsubsection{Amplificação da região 16S rRNA do DNA total}

A amplificação do gene $16 \mathrm{~S}$ rDNA da população microbiana das amostras de água foi realizada utilizado os iniciadores $27 \mathrm{~F}$ e $1041 \mathrm{R}$ já descritos anteriormente no item 4.5.4.1

As reações foram feitas em um volume final de $50 \mu \mathrm{L}$, sendo $1 \mathrm{X}$ de solução tampão (Invitrogen), 1,5 $\mathrm{mM}$ de $\mathrm{MgCl}_{2}$ (Invitrogen), 0,25 $\mathrm{mM}$ de dNTPs (Invitrogen), 0,3 $\mu \mathrm{M}$ de cada iniciador (Invitrogen) e $2 \mathrm{U}$ da enzima Taq polimerase (Invitrogen). Em todas as reações foi utilizado um controle negativo, onde o DNA foi substituído por água ultrapura.

A reação de amplificação foi realizada de acordo com as seguintes condições: desnaturação inicial a $94{ }^{\circ} \mathrm{C}$ por 2 minutos, seguindo-se 25 ciclos de amplificação consistindo de desnaturação a $94{ }^{\circ} \mathrm{C}$ por 30 segundos, anelamento a $62,5^{\circ} \mathrm{C}$ por 1 minuto, extensão a 72 ${ }^{\circ} \mathrm{C}$ por 45 segundos e uma extensão final a $72{ }^{\circ} \mathrm{C}$ por 3 minutos em termociclador 
(Mastercycler ep Gradient S - Eppendorf). Foram realizadas amplificações em 4 réplicas para posterior clonagem e análise das seqüências.

Os fragmentos do gene 16S rDNA das 4 réplicas de amplificação foram visualizados por eletroforese em gel de agarose $1 \%(\mathrm{p} / \mathrm{v})$ em tampão TAE $1 \mathrm{X}$, juntamente com $5 \mu \mathrm{L}$ do marcador de peso molecular $1 \mathrm{~Kb}$ Plus DNA Ladder (Invitrogen). O gel foi corado em solução de Brometo de etídio $(0,5 \mathrm{ug} / \mathrm{mL})$ por 10 minutos e fotografado em fotodocumentador modelo GEL DOC XR System (Bio-Rad).

\subsubsection{Preparação das amostras para clonagem}

Após a confirmação do tamanho esperado dos amplicons, os mesmos foram transferidos para um único tudo de microcentrífuga e purificados com o Kit Ilustra GFX ${ }^{\mathrm{TM}}$ PCR DNA and Gel Band Purification (28-9034-70, GE Healthcare) e eluídos em $30 \mu \mathrm{L}$ de água ultrapura, seguindo as instruções do fabricante. Depois do processo de purificação, $1 \mu \mathrm{L}$ do amplicon purificado, agora pronto para ser ligado ao vetor de clonagem, foi visualizado em gel de agarose $1 \%$ com $2 \mu \mathrm{L}$ do marcador Low DNA Mass Ladder (Invitrogen) e quantificado por espectrofotometria em um aparelho NanoDrop® ND-1000 (Thermo Scientific). O gel foi corado em solução de Brometo de etídio $(0,5 \mathrm{ug} / \mathrm{mL})$ por 10 minutos e o resultado foi visualizado em fotodocumentador modelo GEL DOC XR System (Bio-Rad).

\subsubsection{Clonagem dos fragmentos amplificados}

\subsubsection{Preparação das células eletrocompetentes}

A linhagem da célula competente usada neste estudo foi a Escherichia coli DH5 $\alpha$, cujo genótipo é supE44, $\Delta l a c \mathrm{U} 169$ ( $\phi 80$, lacZ $\Delta \mathrm{M} 15)$, hsdR17, recA1, endA1, gyrA96, thi-1, relA1).

As células eletrocompetentes de E. coli DH5 $\alpha$ foram preparadas conforme Sambrook e Russell (2001). Células de E. coli DH5 $\alpha$ foram cultivadas em $5 \mathrm{~mL}$ de meio LB e incubadas a $37{ }^{\circ} \mathrm{C}$ por 16 horas a 180 r.p.m. Em seguida, a cultura foi vertida em $500 \mathrm{~mL}$ de meio LB e cultivada a $37{ }^{\circ} \mathrm{C}$, sob agitação a 180 r.p.m., até uma D.O.600 nm de 0,5. As células foram coletadas por centrifugação e lavadas duas vezes com água ultrapura gelada contendo $10 \%$ 
(v/v) de glicerol. Em seguida, as células foram concentradas em $1 \mathrm{~mL}$ de glicerol 10\% (v/v), aliquotadas em $40 \mu \mathrm{L}$ e estocadas a $-70^{\circ} \mathrm{C}$ até o momento do uso.

\subsubsection{Ligação fragmento-vetor e transformação das células competentes}

A clonagem dos fragmentos do gene $16 \mathrm{~S}$ rDNA foi feita em plasmídeo $p G E M \circledR-T$ Easy Vector System (Promega) (Figura 9) seguindo as instruções do fabricante. Este vetor é conveniente para clonagem de produtos de PCR, apresentando alto número de cópias, múltiplos sítios de clonagem e permite rápida seleção de recombinantes usando IPTG e XGal.

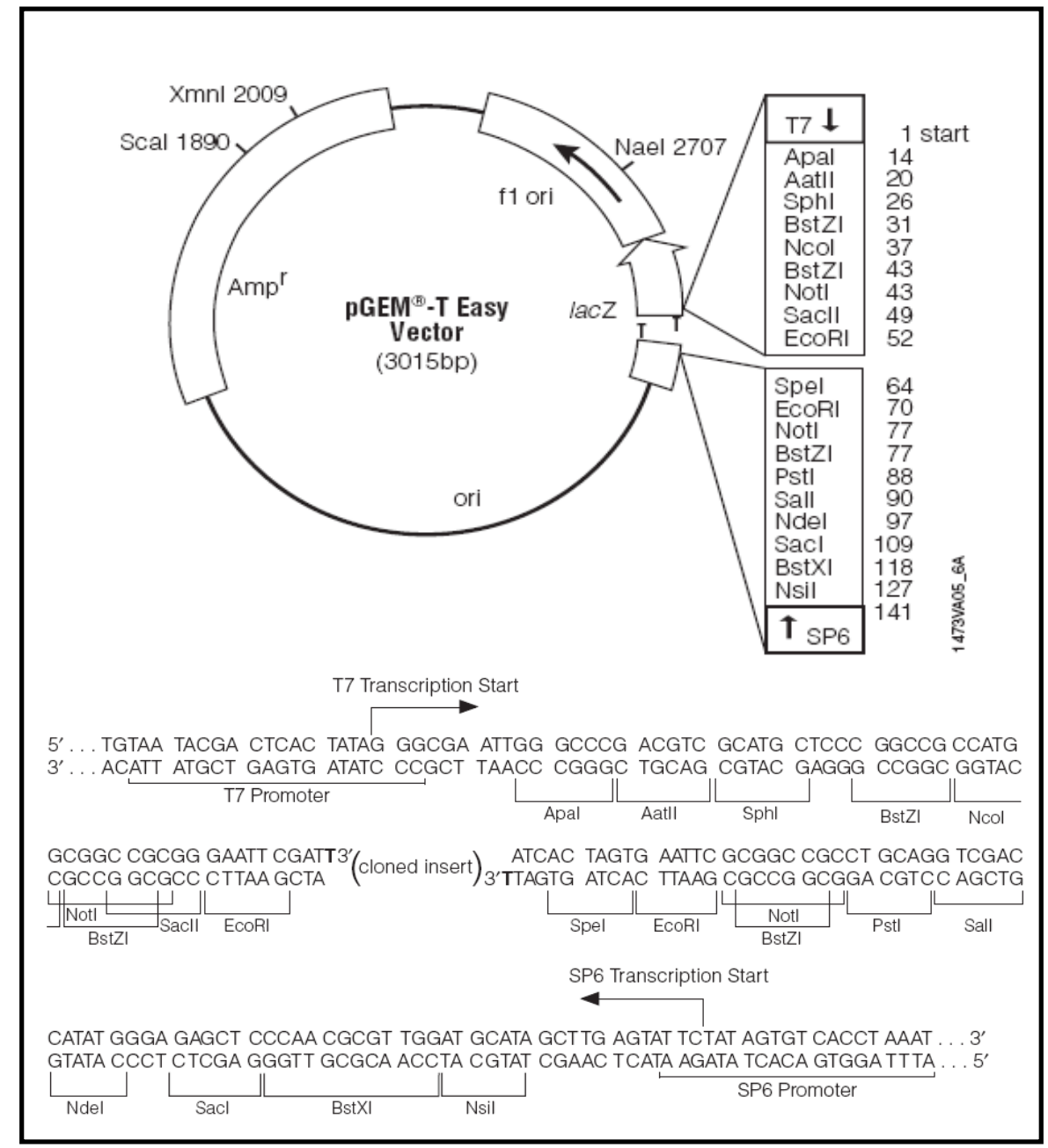

Figura 9 - Figura esquemática do plasmídeo $p G E M ®-T$ Easy e do múltiplo sítio de clonagem. Amp ${ }^{\mathrm{r}}$ : gene de resistência a ampicilina; ori: origem de replicação; T7: sítio de início de transcrição da T7 RNA polimerase; SP6: sítio de início de transcrição da SP6 RNA polimerase.

FONTE: Catálogo do produto. 
Inicialmente foi realizado o cálculo da razão inserto:vetor de acordo com a fórmula:

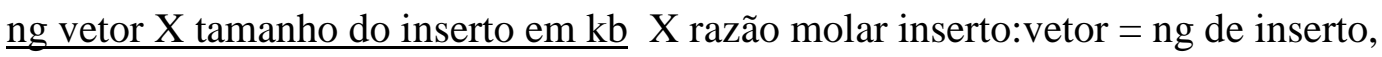
tamanho do vetor em $\mathrm{kb}$

onde foram utilizados $50 \mathrm{ng}$ de vetor, os fragmentos inseridos foram de 1,5 kb, o tamanho do vetor é $3 \mathrm{~kb}$ e a razão molar utilizada foi de 3:1. Logo, pela substituição dos fatores, a fórmula apresenta-se:

$\underline{50 \mathrm{ng} X 1,5 \mathrm{~kb}} \times 3: 1=75$ ng de inserto

$3 \mathrm{~kb}$

A reação de ligação inserto:vetor foi realizada a $4{ }^{\circ} \mathrm{C}$, por cerca de $16 \mathrm{~h}$.

A reação de transformação foi feita com $2 \mu \mathrm{L}$ da ligação inserto:vetor e $40 \mu \mathrm{L}$ de células competentes de E. coli DH5 $\alpha$. A eletrotransformação foi realizada em eletroporador Gene Pulser (Bio-Rad) com os seguintes ajustes: voltagem de 2,5 V, $200 \Omega$ de resistência e 25 $\mu \mathrm{F}$ de capacitância. Após a eletroporação, as células transformadas foram recuperadas em 960 $\mathrm{mL}$ de meio SOC (Anexo A7) a incubação de $37^{\circ} \mathrm{C}$ por 1 hora a 150 r.p.m.

Em seguida, $100 \mu \mathrm{L}, 150 \mu \mathrm{L}$ e $200 \mu \mathrm{L}$, em duplicata, das células transformadas foram inoculadas por espalhamento com alça de vidro em placas de ágar Luria-Bertani (LB) contendo ampicilina [AMP $\left(100 \mu \mathrm{g} \cdot \mathrm{mL}^{-1}\right)$ ], isopropyl- $\beta$-D-thiogalactopyranoside [IPTG $(0,1 \mathrm{M})]$ e 5-bromo-4-chloro-3-indolyl- $\beta$-D-galactopyranoside $\quad\left[\mathrm{X}-\mathrm{Gal} \quad\left(50 \mathrm{mg} \cdot \mathrm{mL}^{-1}\right)\right]$ e incubadas a $37^{\circ} \mathrm{C}$ por $16 \mathrm{~h}$. O meio LB:AMP pode ser preparado dias antes do inóculo, mas a adição de IPTG e X-Gal ao meio devem ser feita, por espalhamento com alça de vidro, aproximadamente 30 a 120 minutos antes de acrescentar o inóculo com as células transformadas.

As colônias com coloração branca (correspondendo aos possíveis clones positivos) foram repicadas novamente em ágar LB contendo ampicilina, IPTG e X-Gal e incubadas a 37 ${ }^{\circ} \mathrm{C}$ por 16 horas para confirmação das células transformadas e isolamento dos clones.

\subsubsection{Detecção do inserto nos clones}

As colônias que apresentaram coloração branca, agora já isoladas, após o segundo repique, foram confirmadas quanto à presença do inserto através da amplificação direta da célula transformada com os iniciadores do vetor (M13), sem a necessidade de extração do 
DNA plasmidial. As colônias foram transferidas, com auxílio de um palito esterilizado, para placas de PCR de 96 poços contendo a reação de amplificação com 1X de solução tampão (Invitrogen), 1,5 $\mathrm{mM}$ de $\mathrm{MgCl}_{2}$ (Invitrogen), 0,25 $\mathrm{mM}$ de dNTPs (Invitrogen), 0,3 $\mu \mathrm{M}$ de cada iniciador do vetor M13F (5' CGC CAG GGT TTT CCC AGT CAC GAC 3') e M13R (5' TTT CAC ACA GGA AAC AGC TAT GAC 3') (Invitrogen) e 2 U da enzima Taq polimerase (Invitrogen) num volume final de $50 \mu \mathrm{L}$. Em todas as reações foi utilizado um controle negativo, onde a colônia foi substituída por água ultrapura.

A reação de amplificação foi realizada segundo as seguintes condições: desnaturação inicial a $97{ }^{\circ} \mathrm{C}$ por 3 minutos, seguindo-se 40 ciclos de amplificação consistindo de desnaturação a $94{ }^{\circ} \mathrm{C}$ por 30 segundos, anelamento a $60^{\circ} \mathrm{C}$ por 30 segundos, extensão a $72{ }^{\circ} \mathrm{C}$ por 1,5 minutos e uma extensão final a $72{ }^{\circ} \mathrm{C}$ por 5 minutos em termociclador (Mastercycler ep Gradient $\mathrm{S}$ - Eppendorf).

Os fragmentos do gene $16 \mathrm{~S}$ rDNA adicionados das sequiências do vetor foram verificados por eletroforese em gel de agarose 1\% (p/v) em tampão TAE 1X, juntamente com $5 \mu \mathrm{L}$ do marcador de peso molecular $1 \mathrm{~Kb}$ Plus DNA Ladder (Invitrogen). O gel foi corado em solução de Brometo de etídio $(0,5 \mathrm{ug} / \mathrm{mL})$ por 10 minutos e visualizado em fotodocumentador modelo GEL DOC XR System (Bio-Rad).

\subsubsection{Preparação dos clones para seqüenciamento}

Os fragmentos de tamanho esperado para os clones do gene 16S rDNA (1.500 pb) foram purificados com o Kit Ilustra GFX ${ }^{\mathrm{TM}} P C R$ DNA and Gel Band Purification (28-903470, GE Healthcare) e eluídos em $30 \mu \mathrm{L}$ de água ultrapura, seguindo as instruções do fabricante. Após purificação, $1 \mu \mathrm{L}$ do produto purificado foi visualizado em gel de agarose $1 \%(\mathrm{p} / \mathrm{v})$ em tampão TAE $1 \mathrm{X}$, juntamente com $2 \mu \mathrm{L}$ do marcador de peso molecular Low DNA Mass Ladder (Invitrogen) e quantificado por dosagem espectrofotométrica em um aparelho NanoDrop® ND-1000 (Thermo Scientific).

\subsubsection{Seqüenciamento dos clones de 16S rRNA}

Para o seqüenciamento dos clones, foi preparada uma reação com $4 \mu \mathrm{L}$ do produto purificado (aproximadamente $80 \mathrm{ng}$ ) e $1 \mu \mathrm{L}$ do iniciador $(5 \mu \mathrm{M})$ para um volume final de 10 $\mu \mathrm{L}$ com o DYEnamic ET Dye Terminator Cycle Sequencing Kit for MegaBace DNA Analysis 
Systems (GE Healthcare) conforme instruções do fabricante e protocolo utilizado no Centro do Genoma Humano/USP. No seqüenciamento foi utilizado o iniciador interno do vetor T7 (5' GTA ATA CGA CTC ACT ATA GGG 3'). Os produtos foram seqüenciados no seqüenciador automático MegaBace 1000 DNA Analysis System (Amersham Life Biosciences) com as seguintes condições: 30 ciclos de amplificação consistindo de desnaturação a $95^{\circ} \mathrm{C}$ por 20 segundos, anelamento a $55^{\circ} \mathrm{C}$ por 15 segundos, extensão a $60{ }^{\circ} \mathrm{C}$ por 1 minuto e uma extensão final a $10^{\circ} \mathrm{C}$, no Centro do Genoma Humano/USP.

\subsection{ANÁLISE DOS RESULTADOS}

\subsubsection{Análise estatística}

As variáveis analisadas foram inicialmente confrontadas com a curva de Gauss (Curva Normal) e classificadas em paramétricas e não paramétricas. Quando as variáveis foram paramétricas, estas foram descritas na forma de média e desvio padrão da amostra e realizado o teste de análise de variância para medidas não repetidas (ANOVA) com Pós-teste de Tukey Modificado para comparação entre os diferentes grupos.

Por outro lado, quando as variáveis foram não-paramétricas, as mesmas foram descritas na forma de mediana e percentis 25 e 75 e utilizado o teste de Kruskal-Wallis com Pós-teste de Müller-Dunn para comparação entre os diferentes grupos. O teste de Friedman com Pós-teste de Müller-Dunn foi utilizado para comparação entre os diferentes meses para avaliar a presença de microrganismos pertencentes ao grupo das proteobactérias usando sondas fluorescentes para comparar os dados obtidos entre os dois pontos estudados.

A correlação Spearman foi usada para testar a relação entre as bactérias marinhas e os indicadores de contaminação fecal, com os resultados de hibridização in situ e fatores abióticos e os resultados que apresentaram valores de $p \leq 0,05$ e r entre 0 e 1 foram considerados estatisticamente significantes.

A análise de regressão linear múltipla foi utilizada para estimar uma ou mais variáveis independentes que melhor predizem o valor da variável dependente nas amostras de água do mar, para tanto foram calculados os valores de Beta (peso da variável no modelo preditor).

Foi considerado para todo o estudo risco alfa de $5 \%(\mathrm{p} \leq 0,05)$ de cometer o erro tipo I e risco beta de $20 \%$ para cometer o erro tipo II ou de $2^{\mathrm{a}}$ espécie. Os valores de correlação (0> $\mathrm{r}<1)$ também foram considerados $(0>\mathrm{r}<0,5=$ correlação fraca; $0,5>\mathrm{r}<0,7=$ correlação moderada; $0,7>\mathrm{r}<1$ = correlação forte). 
Foram utilizados para os cálculos estatísticos os programas SPSS (Statistical Package for Social Sciences) versão 15.0 e GraphPad Prism, versão 5.00 para Windows (GraphPad Software, San Diego, California, USA).

\subsubsection{Análise dos agrupamentos obtidos na tipagem molecular por BOX-PCR e ERIC- PCR}

Os perfis genéticos gerados pelas técnicas de BOX-PCR e ERIC-PCR foram analisados utilizando-se o software BioNumerics (Applied Maths, Bélgica), versão 5.00, onde árvores filogenéticas (dendrogramas) foram construídas.

A análise de agrupamento foi construída utilizando os coeficientes de similaridade simples, de Dice e de Jaccard e os agrupamentos foram realizados utilizando o algoritmo UPGMA (Unweighted Pair Group Method using Arithmetic Average). Essas análises foram feitas seguindo o limite de tolerância de bandas de $1 \%$ (band position tolerance).

\subsubsection{Análise das seqüências de 16S rRNA de isolados bacterianos e de bibliotecas de clones}

As seqüências de DNA obtidas tiveram seus cromatogramas analisados e, posteriormente foram editadas e alinhadas no programa BioEdit Sequence Alignment Editor, versão 7.0.9.0 (HALL, 1999). Após edição, as seqüências foram comparadas com seqüências disponibilizadas no banco de dados do Ribosomal Database Project II (RDP II) do Center for Microbial Ecology - Michigan State University através das ferramentas Classifier e SeqMatch, utilizando o limite de confiança de $80 \%$ e do banco de dados do GenBank do National Center for Biotechnology Information (NCBI), utilizando-se o algoritmo BlastN (ALTSCHUL et al., 1990).

Após o alinhamento múltiplo das sequiências obtidas com as sequiências de linhagens tipo disponibilizadas no RDP II, uma árvore filogenética foi construída com a utilização do programa MEGA 4 (TAMURA et al., 2007), através do método de Neighbor-Joining (SAITOU e NEI, 1987), modelo de substituição de nucleotídeos por Jukes-Cantor (JUKES e CANTOR, 1969) e valor de bootstrap de 1000 repetições. 


\subsection{4 Índices de Diversidade e Riqueza das bibliotecas gênicas}

Para análise de diversidade e índice de riqueza as sequiências foram alinhadas usando o CLUSTAL W. A similaridade entre as seqüências foi calculada com o DNADIST do pacote de software PHYLIP (Phylogeny Inference Package), versão 3.68 (http://evolution.genetics.washington.edu/phylip.htlm) usando o modelo de substituição de nucleotídeos por Jukes-Cantor.

Usando a matriz de similaridade gerada, as sequiências foram atribuídas a Unidades Taxonômicas Operacionais (OTUs) através do programa DOTUR (Distance-Based OTU and Richness), versão 1.52 (SCHLOSS e HANDELSMAN, 2005). Os dados de freqüência atribuídos a OTU para espécies (97\% de similaridade), gênero (95\% de similaridade) e filo (80\% de similaridade) foram usados para construir as curvas de rarefação, índice de diversidade de Shannon ( $H^{\prime}$ ) (MAGURRAN, 1988) e os estimadores de riqueza de Chao1 (CHAO, 1984) e ACE (Abundance-based Coverage Estimator) (CHAO e LEE, 1992). 


\section{RESULTADOS}

\subsection{COLETA DE AMOSTRAS DE ÁGUA DO MAR}

Durante os 20 meses de amostragem (agosto/2005 a março/2007), um total de 40 amostras de água do mar foi analisada neste estudo, sendo 20 amostras do ponto 1 e 20 do ponto 2 .

\subsection{CARACTERIZAÇÃO FÍSICO-QUÍMICA DAS AMOSTRAS DE ÁGUA DO MAR}

Levando-se em consideração os valores dos parâmetros físico-químicos fornecidos pelo CEBIMar-USP, no Canal de São Sebastião no dia da coleta de amostras, verifico-se que as variações foram: temperatura da água do mar $\left(21,5\right.$ a $\left.26,3{ }^{\circ} \mathrm{C}\right)$, temperatura do ar $(18$ a 28 ${ }^{\circ} \mathrm{C}$ ), salinidade (34 a 35\%), condutividade (37,6 a 49,4 mS), pH (8,10 a 8,61), oxigênio dissolvido $(5,22$ a 7,08) e umidade relativa do ar (62 a 96\%) (Figura 10). Os valores mensais podem sem vistos no Anexo B.

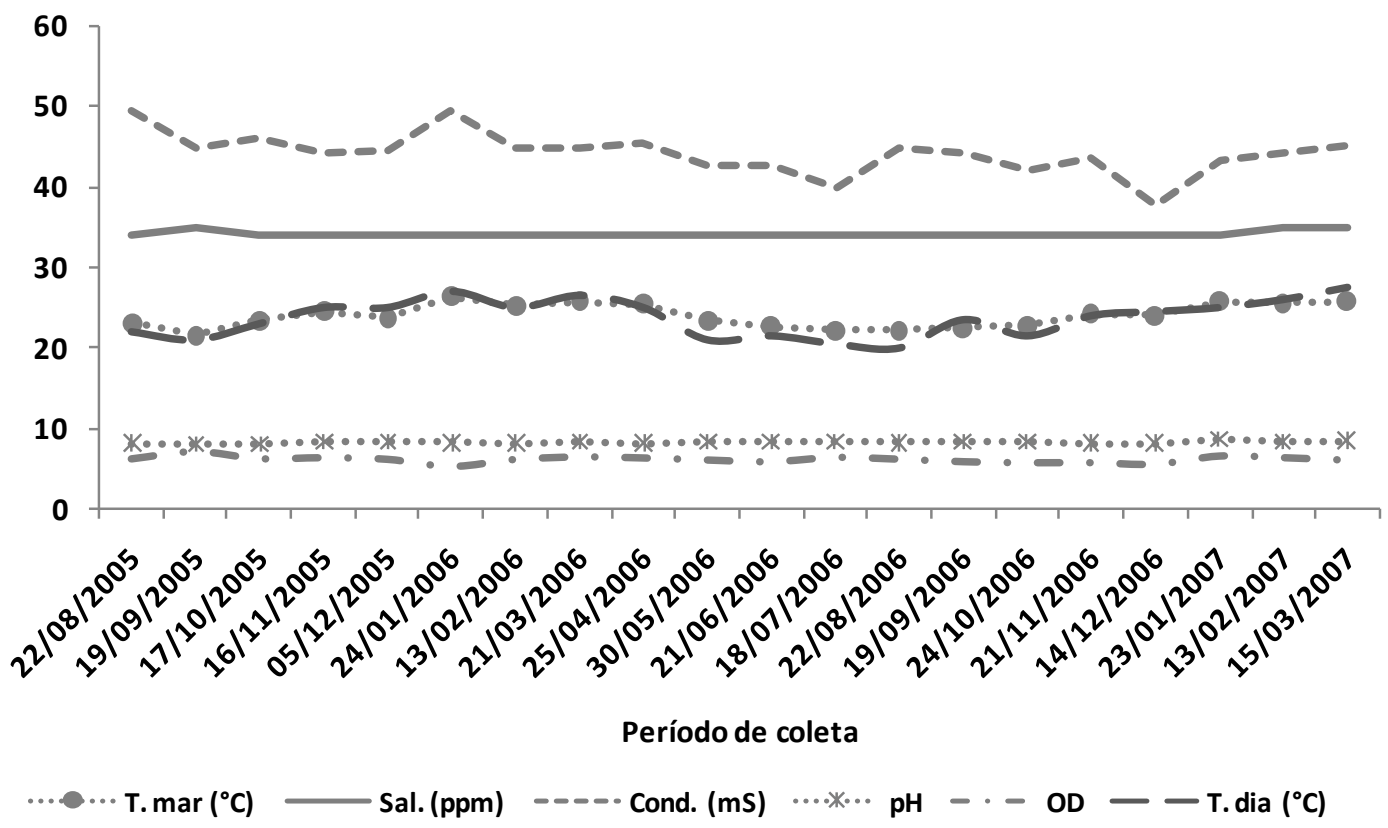

Figura 10 - Variação dos valores dos parâmetros físico-químicos medidos no Canal de São Sebastião. T. mar $\left({ }^{\circ} \mathbf{C}\right)$ : temperatura da água do mar; Sal (ppm): salinidade; Cond. $(\mathbf{m S})$ : condutividade; OD: oxigênio dissolvido; T. dia $\left({ }^{\circ} \mathbf{C}\right)$ : temperatura do ar (média dos valores mínimos e máximos). 


\subsection{CARACTERZAÇÃO DA QUALIDADE MICROBIOLÓGICA DAS AMOSTRAS DE ÁGUA DO MAR}

\subsubsection{Contagem e isolamento de bactérias marinhas}

Os resultados das contagens em placa efetuadas com as amostras coletadas no ponto 1 mostraram que a concentração de bactérias marinhas encontrada variou de 2,6 x $10^{1}$ a 3,4 x $10^{3} \mathrm{UFC} / \mathrm{mL}$, sendo observada a variação na mesma ordem de magnitude no ponto $2(2,0 \mathrm{x}$ $10^{1}$ a $1,9 \times 10^{3} \mathrm{UFC} / \mathrm{mL}$ ) (Figura 11 ).

A variação entre as concentrações de bactérias marinhas obtida entre os pontos de coleta e mostrou um valor de significância calculada (p) superior $(\mathrm{p}=0,829)$ ao valor de significância adotada $(\alpha)$, ou seja, $p>0,05$. Sendo assim, podemos concluir que ambos os pontos são estatisticamente semelhantes, em relação às contagens de bactérias marinhas descritas. Os valores da mediana e percentil podem ser visualizados na figura 12 .

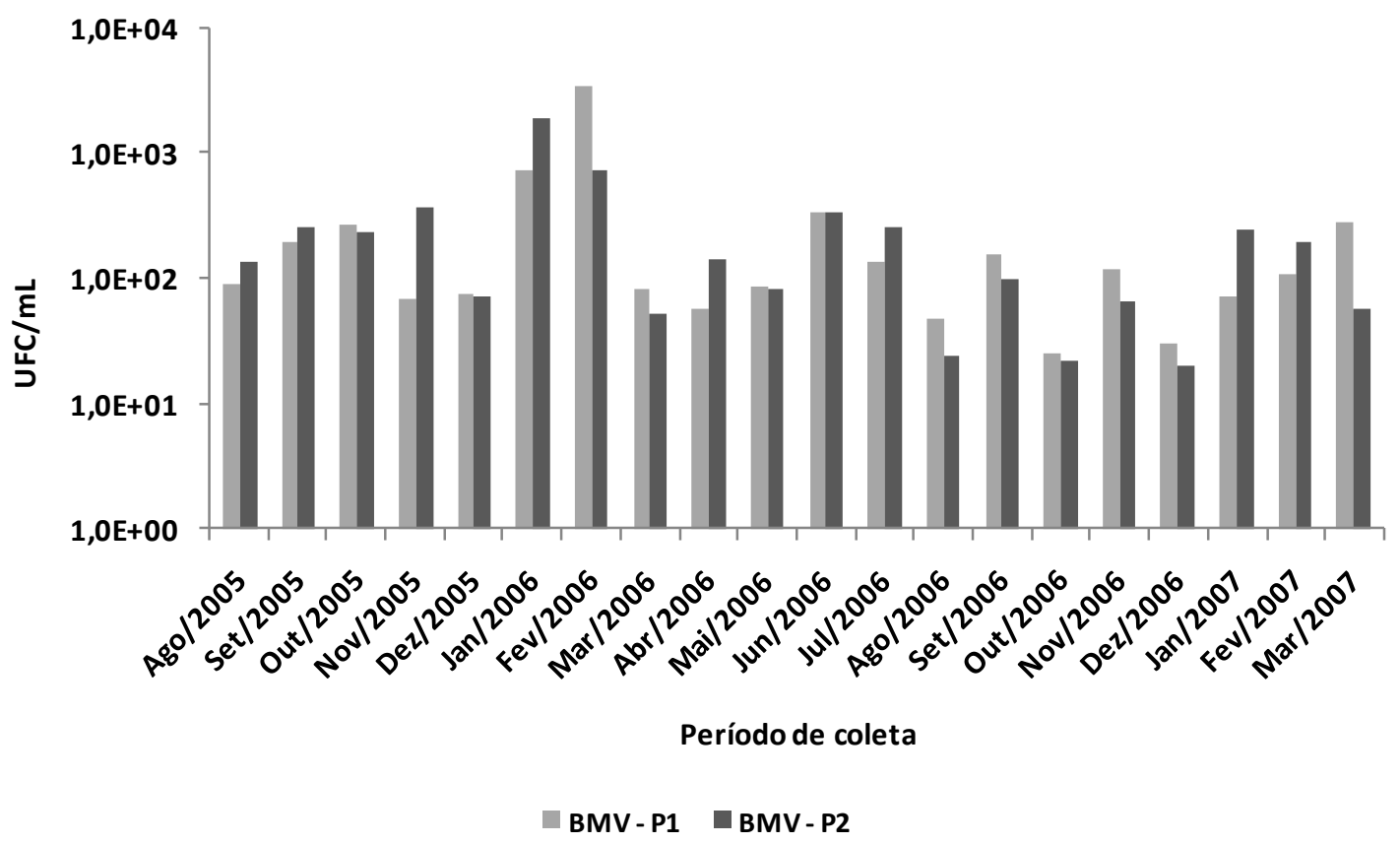

Figura 11 - Variação da concentração de Bactérias Marinhas Viáveis (BMV) em amostras de água do Canal de São Sebastião por ponto de coleta. 


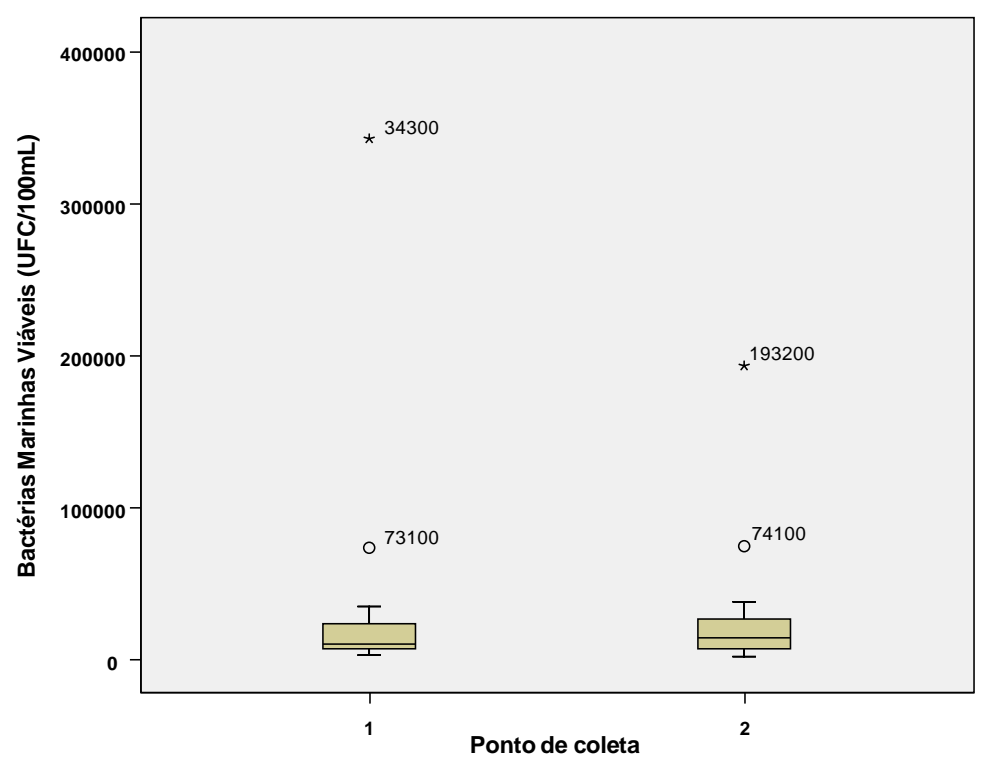

Figura 12 - Boxplot mostrando os valores da mediana e percentis 25 e 75 das contagens de Bactérias Marinhas Viáveis por ponto de coleta.

Nota: Para efeito de visualização, as contagens de Bactérias Marinhas Viáveis estão apresentadas em UFC/100 mL.

O teste de correlação Spearman foi aplicado nestas amostras e verificou-se que houve uma fraca correlação positiva entre as contagens de bactérias marinhas e coliformes termotolerantes $(p=0,002$ e $r=0,467)$ e entre bactérias marinhas e enterococos intestinais $(p=$ $0,030$ e $\mathrm{r}=0,344)$. O mesmo teste foi aplicado para verificar se a variação nas contagens mensais de bactérias marinhas viáveis estavam correlacionadas com os parâmetros físicoquímicos (temperatura, salinidade, condutividade, $\mathrm{pH}$ e oxigênio dissolvido), mas não foi verificada nenhuma correlação significativa. Além disso, de acordo com o Teste de MannWhitney não foi verificada nenhuma relação estatisticamente significativa entre condições climáticas (corrente marítima, direção do vento e condição do tempo) e concentração bacteriana.

Com as 40 amostras de água do mar coletadas nos dois pontos foi possível obter 295 isolados de bactérias marinhas, dos quais 143 foram isolados das 20 amostras coletadas no ponto 1 e, 152 foram isolados dos restantes das amostras coletadas no ponto 2.

\subsubsection{Caracterização fenotípica das bactérias marinhas}

Do total de 295 bactérias marinhas, 280 foram submetidas à coloração de Gram. Destes, $242(86,4 \%)$ foram classificados como bactérias gram-negativas e $38(13,6 \%)$ como 
gram-positivas. O método de $\mathrm{KOH}$ confirmou esses resultados, apresentando $240(85,7 \%)$ isolados como bactérias gram-negativas e 40 (14,3\%) como gram-positivas.

Sendo assim, podemos dizer que a maioria $(86,4 \%)$ dos isolados de bactérias marinhas pertencem ao grupo das bactérias gram-negativas. Os outros 15 isolados não foram submetidos à coloração de Gram, pois os mesmos não se apresentavam mais no estado cultivável.

Estes isolados foram submetidos a estes dois testes com a finalidade de selecionar somente as bactérias gram-negativas, já que o enfoque deste trabalho é analisar a diversidade de bactérias isoladas pertencentes ao Filo Proteobacteria.

\subsubsection{Qualidade microbiológica das amostras de água do mar}

A contagem de coliformes termotolerantes e enterococos intestinais foi efetuada nessas amostras a fim de verificar a qualidade microbiológica da água do mar do Canal de São Sebastião nos pontos de coleta. Os resultados das contagens mostraram que não houve diferença estatística entre as contagens de ambos os pontos (valores estatísticos não mostrados). Sendo assim, a média dos valores encontrados tanto no ponto 1 quanto no ponto 2 foi determinada e assim os resultados foram expressos.

Os valores observados para contagens de coliformes termotolerantes e enterococos intestinais variaram de $<1$ a 1,7 x $10^{2} \mathrm{UFC} / 100 \mathrm{~mL}$ e $<1$ a 3,1 x $10^{1} \mathrm{UFC} / 100 \mathrm{~mL}$, respectivamente. Entretanto, para melhor visualização gráfica, esses valores foram expressos em Log de UFC/100 mL + 1 (Figura 13). Nesta mesma figura também são apresentados os resultados de bactérias marinhas viáveis apenas para facilitar a comparação entre estes indicadores, visto que essas contagens tiveram correlação, mesmo que fraca, com coliformes termotolerantes $(r=0,467$ e $p=0,002)$ e enterococos intestinais $(r=0,344$ e $p=0,030)$. 


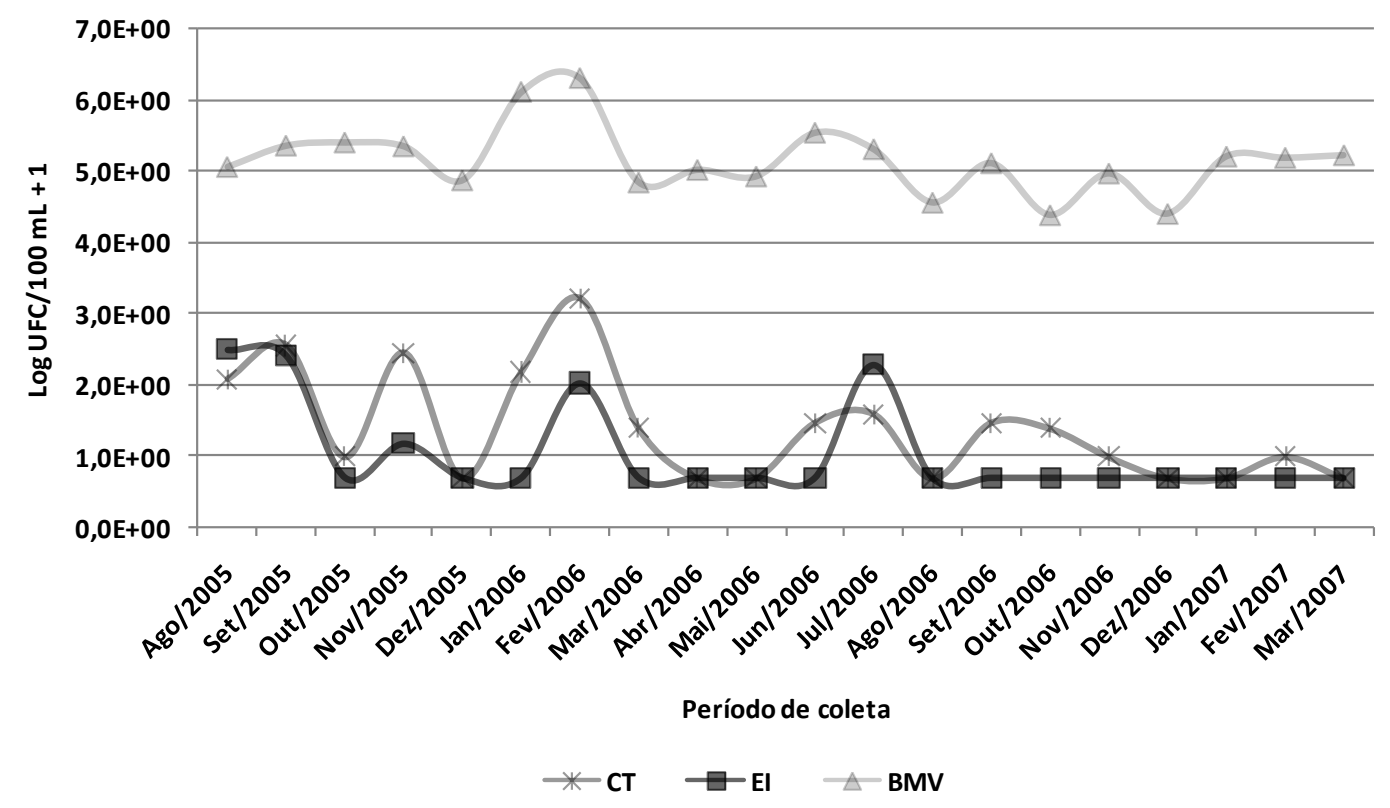

Figura 13 - Média da variação de Bactérias Marinhas Viáveis (BMV), Coliformes Termotolerantes (CT) e Enterococos Intestinais (EI) nas amostras de água do mar durante o período de coleta no Canal de São Sebastião.

Nota: Para efeito de visualização, as contagens dos três indicadores estão apresentadas em UFC/100 mL.

\subsection{CARACTERIZAÇÃO MOLECULAR DOS ISOLADOS DE BACTÉRIAS MARINHAS}

\subsubsection{Extração do DNA genômico}

Foi realizada a extração de DNA de cada uma das bactérias marinhas que foram classificados como gram-negativas, com exceção de 2 isolados que não cresceram no meio de cultura líquido.

O Kit Wizard ${ }^{\circledR}$ Genomic DNA Purification (Promega) possibilitou extrair DNA de boa qualidade, assim também como as suas concentrações foram adequadas, conforme foi verificado que à razão O.D. $260 \mathrm{~nm} / 280 \mathrm{~nm}$ foi de 1,8-2,0 quando medido em um aparelho NanoDrop® ND-1000 (Thermo Scientific) e através de gel de agarose. Todavia, para se obter concentrações de DNA acima de $100 \mathrm{ng} / \mu \mathrm{L}$ foi necessário aumentar a quantidade de suspensão bacteriana de $1 \mathrm{~mL}$, como recomendado pelo fabricante, para $3 \mathrm{~mL}$. 


\subsubsection{Tipagem molecular utilizando os métodos BOX-PCR e ERIC-PCR}

Os testes foram inicialmente padronizados utilizando o DNA de cepas padrão de Vibrio cholerae O1 (RC 11, RC 230, RC 231 e 569 B) gentilmente cedidas pela Dra Rita R. Colwell da Universidade de Maryland, EUA. Estas cepas foram usadas como controle porque esta bactéria já possui um perfil conhecido para essas técnicas.

Além disso, as reações de padronização permitiram confirmar a reprodutibilidade das técnicas de ERIC-PCR e BOX-PCR, já que o perfil de bandas desses isolados analisados foram confirmados em todas as reações.

Todas as 240 bactérias marinhas foram submetidas à tipagem molecular pelas técnicas de BOX-PCR e ERIC-PCR, os quais puderam ter os seus perfis observados através da visualização em gel de agarose (Figuras 14 e 15).

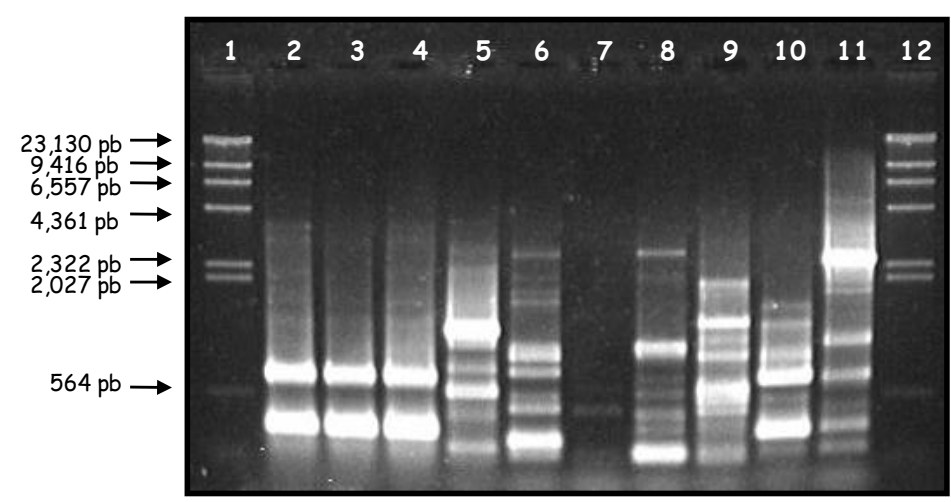

Figura 14 - Fotografia de gel de agarose 1\% em tampão TAE 1X exemplificando a amplificação de bactérias marinhas pela técnica de BOX-PCR. Colunas 1 e 12: marcador de peso molecular Lambda DNA/Hind III - Promega; Colunas 2 - 11: perfis de bactérias marinhas.

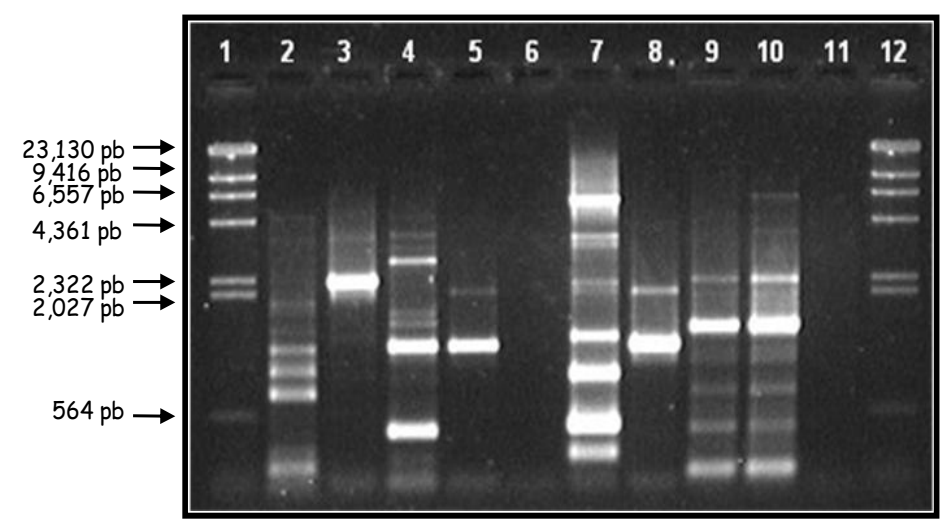

Figura 15 - Fotografia de gel de agarose 1\% em tampão TAE 1X exemplificando a amplificação de bactérias marinhas pela técnica de ERIC-PCR. Colunas 1 e 12: marcador de peso molecular Lambda DNA/Hind III - Promega; Colunas 2 - 11: perfis de bactérias marinhas. 
Os 240 isolados bacterianos gram-negativos, após terem sido avaliados quanto aos seus perfis de bandas gerados por essas técnicas de fingerprintings, foram analisados quanto aos agrupamentos desses perfis através da construção de dendrogramas mensais para verificar a prevalência dos isolados. No entanto, como o número de isolados não foi constante devido à variação da concentração de bactérias em cada mês, não foi possível encontrar nenhuma similaridade entre os isolados obtidos em cada mês. Sendo assim, optou-se por construir um único dendrograma para cada tipo de técnica empregada.

Para a análise de agrupamentos, os géis desses isolados foram normalizados em relação aos padrões de bandas e foram submetidos à comparação dos métodos baseados em bandas. As similaridades calculadas, utilizando os coeficientes de Dice e Jaccard, foram comparadas utilizando o valor de porcentagem de similaridade obtido do agrupamento gerado pelo algoritmo UPGMA.

Para analisar o relacionamento entre as cepas a partir dos padrões de bandas obtidos pelas técnicas descritas foi observado que o coeficiente de Dice foi mais eficiente, pois apresentou maior valor de similaridade e maior número de agrupamentos entre os isolados que o coeficiente de Jaccard. Assim, todos os dendrogramas foram analisados utilizando-se o coeficiente de Dice com a posição de tolerância de $1 \%$.

\subsubsection{BOX-PCR}

De acordo com os resultados da técnica de BOX-PCR, verificou-se que das 240 bactérias marinhas analisadas, $217(90,4 \%)$ amplificaram duas ou mais bandas de DNA que variaram de 0,3 a 7,0 Kb, 10 (4,2\%) não apresentaram produtos de amplificação e 13 (5,4\%) amplificaram somente 1 banda. Estas últimas 23 bactérias não foram consideradas no momento de construir o dendrograma para análise desta técnica. Assim, são apresentados os resultados de 217 bactérias marinhas (Figura 16).

De acordo com a análise do dendrograma obtido pelo coeficiente de Dice nos foi permitido observar que existe uma similaridade de 7,4\% entre as 217 bactérias marinhas. Foram identificados basicamente 47 clusters com similaridade maior que $70 \%$, onde 8 apresentaram $100 \%$ de similaridade. Além desses últimos, pôde-se observar mais 7 subclusters com $100 \%$ de similaridade.

Entre estes clusters e subclusters com $100 \%$ de similaridade $53,3 \%$ foram formados por isolados que foram coletados no mesmo mês e ano, enquanto que os outros $(46,7 \%)$ foram 
formados pelo agrupamento de bactérias marinhas que foram isoladas em meses e anos diferentes, embora 2 destes agrupamentos tenham sido formados por 3 isolados, onde 2 deles eram do mesmo período. Por este motivo, foi observado que nem todos os agrupamentos foram formados por isolados que tinham características sazonais semelhantes. 


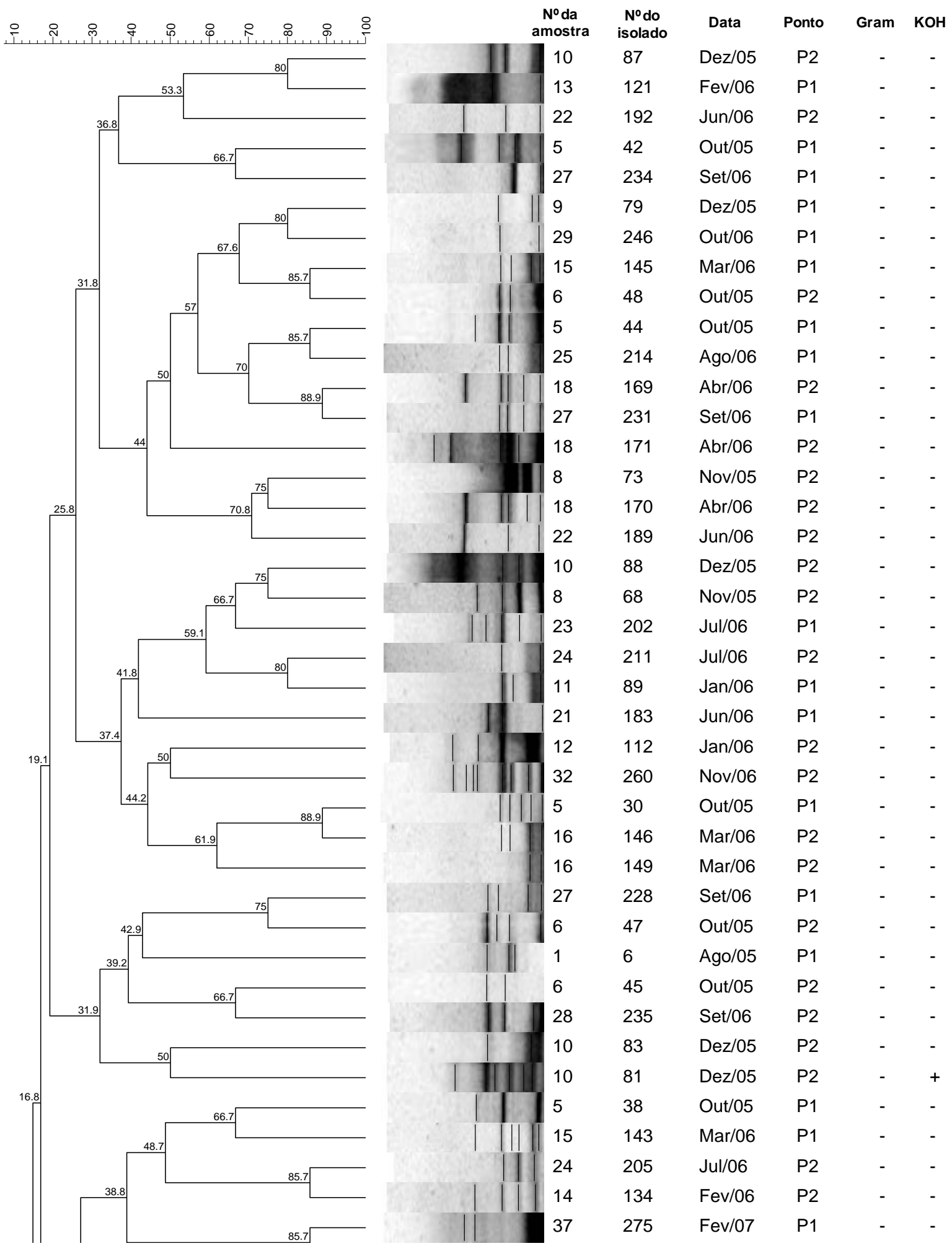

Figura 16 - Dendrograma construído pelo programa BioNumerics para a técnica de BOX-PCR, usando o coeficiente de Dice, com as bactérias marinhas. 


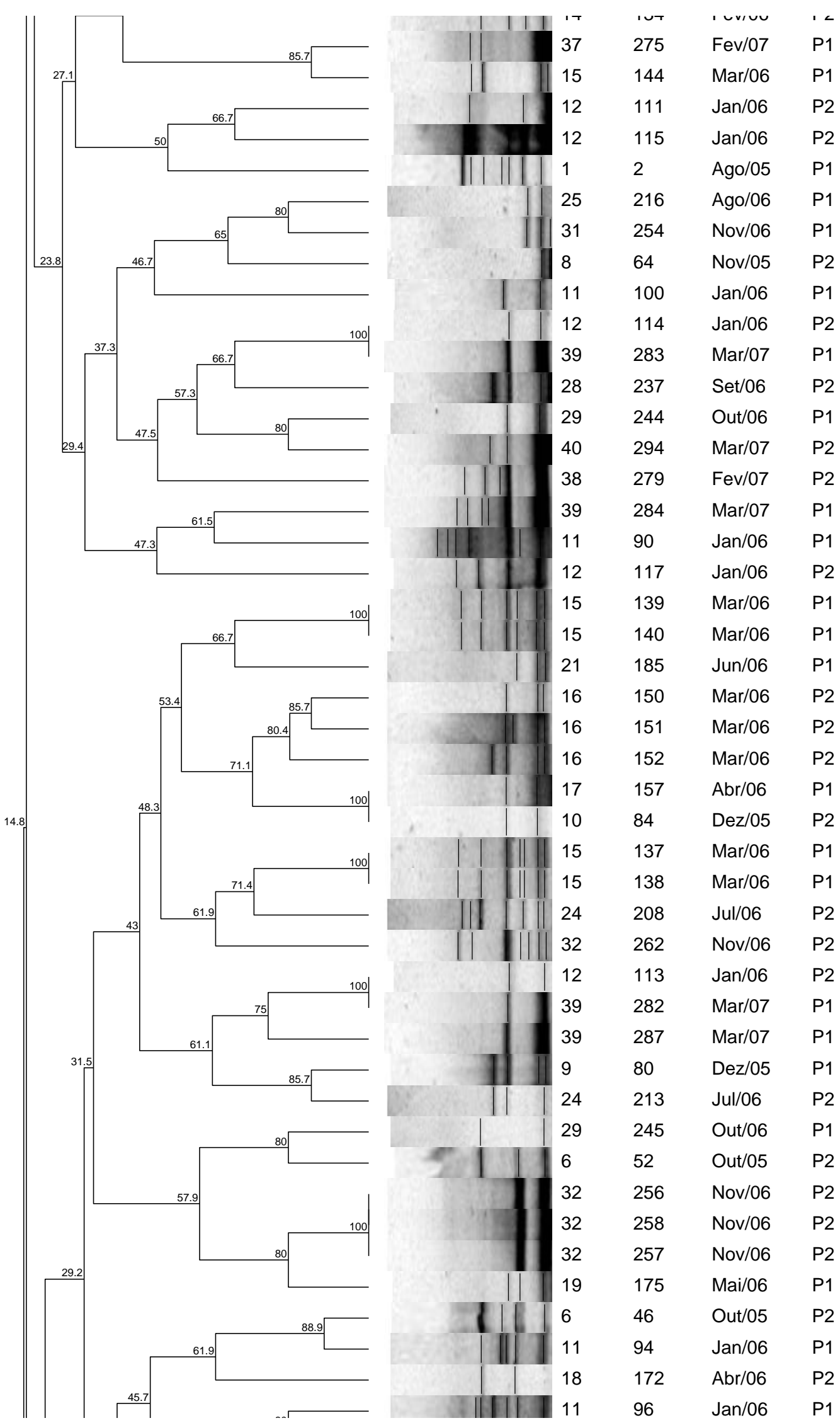

Figura 16 - Dendrograma construído pelo programa BioNumerics para a técnica de BOX-PCR, usando o coeficiente de Dice, com as bactérias marinhas. 


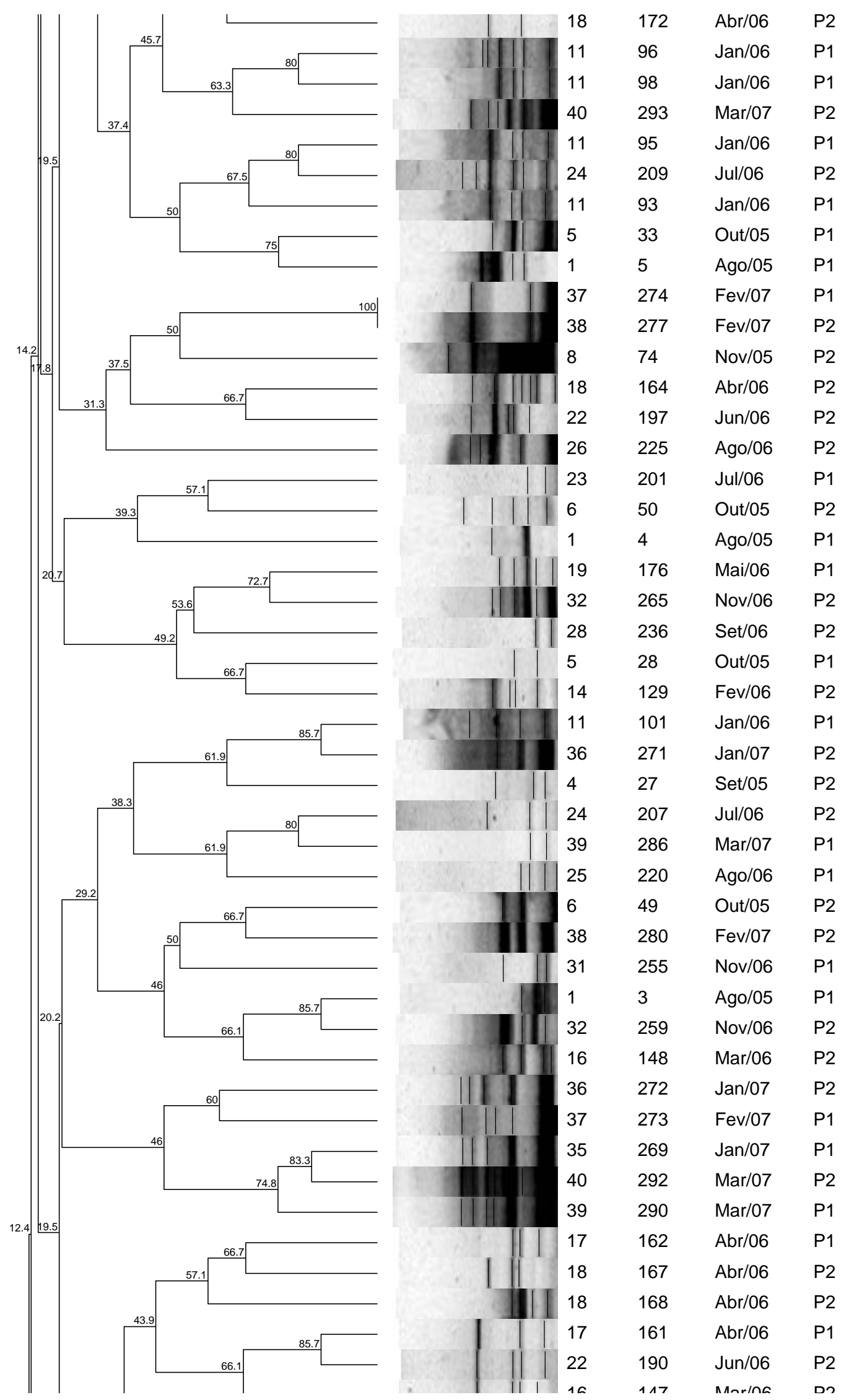

Figura 16 - Dendrograma construído pelo programa BioNumerics para a técnica de BOX-PCR, usando o coeficiente de Dice, com as bactérias marinhas. 


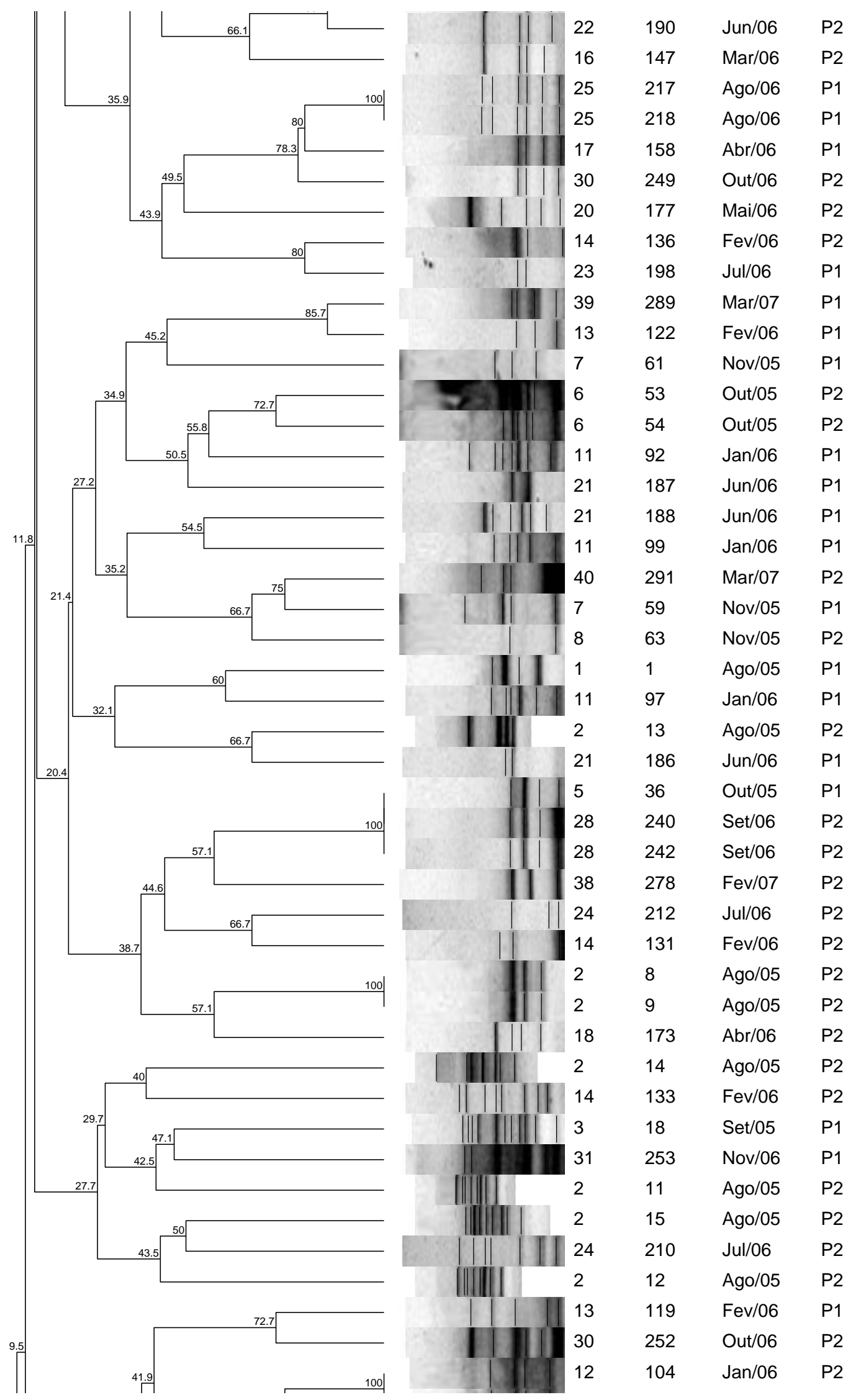

Figura 16 - Dendrograma construído pelo programa BioNumerics para a técnica de BOX-PCR, usando o coeficiente de Dice, com as bactérias marinhas. 


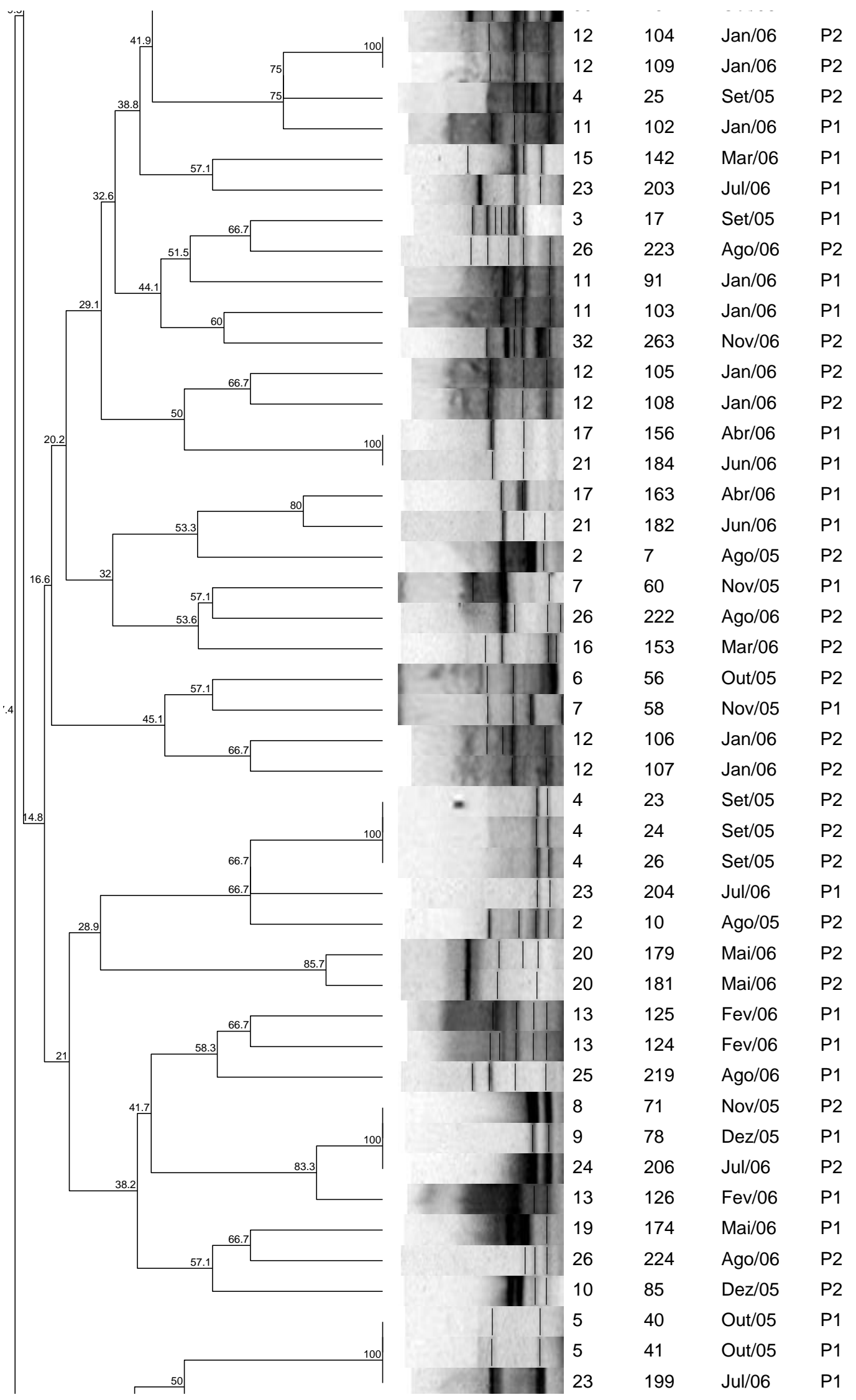

Figura 16 - Dendrograma construído pelo programa BioNumerics para a técnica de BOX-PCR, usando o coeficiente de Dice, com as bactérias marinhas. 


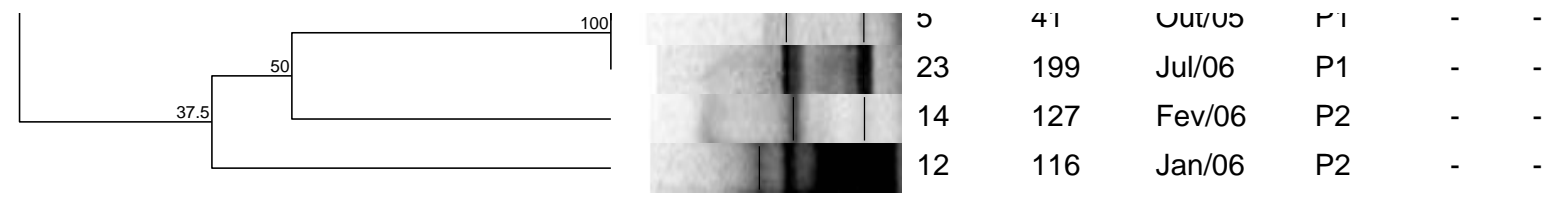

Figura 16 - Dendrograma construído pelo programa BioNumerics para a técnica de BOX-PCR, usando o coeficiente de Dice, com as bactérias marinhas.

\subsubsection{ERIC-PCR}

Os isolados submetidos à técnica de ERIC-PCR não apresentaram bons resultados. Com essa técnica só foi possível amplificar 109 (45,4\%) isolados com duas ou mais bandas de DNA variando de 0,3 a 8,0 Kb. A maioria das bactérias marinhas não apresentou produtos de amplificação $(25,8 \%)$ ou apresentou apenas 1 banda (28,8\%). Estes 131 isolados não foram considerados no momento de construir o dendrograma para análise desta técnica. Assim, são apresentados os resultados de 109 bactérias marinhas (Figura 17).

O dendrograma analisado nos permitiu observar que existe uma porcentagem de similaridade de 5,7\% entre todos os 109 isolados de bactérias marinhas. Este dendrograma foi dividido basicamente em 14 clusters com similaridade maior que $70 \%$, onde 7 apresentaram $100 \%$ de similaridade. No total, pôde-se observar 7 clusters e 5 subclusters com $100 \%$ de similaridade.

Não muito diferente dos resultados obtidos nos clusters de BOX-PCR, com esta técnica a maioria dos agrupamentos (8 agrupamentos) que tiveram 100\% de similaridade também foram formados por bactérias marinhas isoladas em meses e anos diferentes, sendo observado que nem todos os agrupamentos foram formados por isolados com características sazonais semelhantes. 


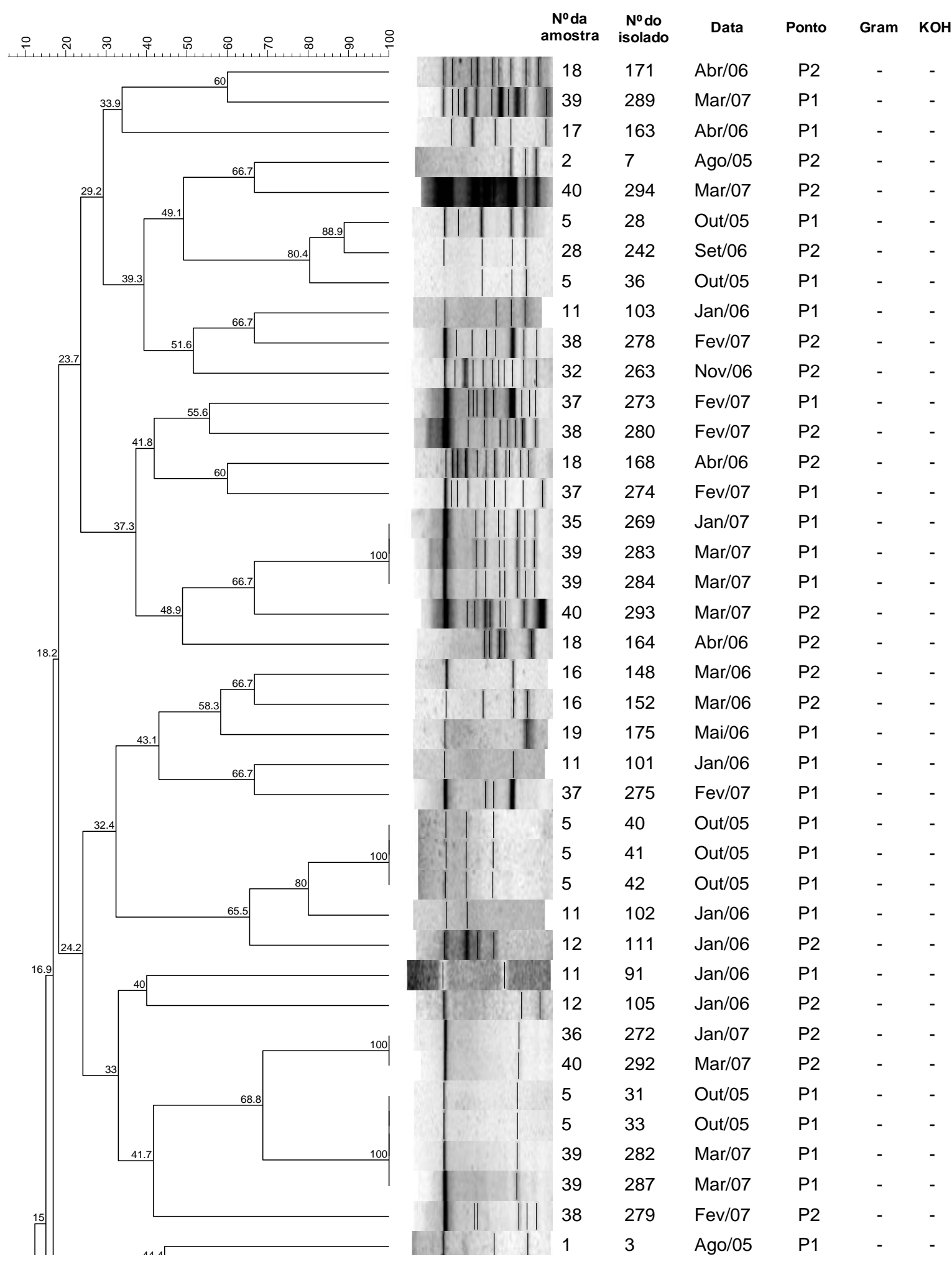

Figura 17 - Dendrograma construído pelo programa BioNumerics para a técnica de ERIC-PCR, usando o coeficiente de Dice, com as bactérias marinhas. 


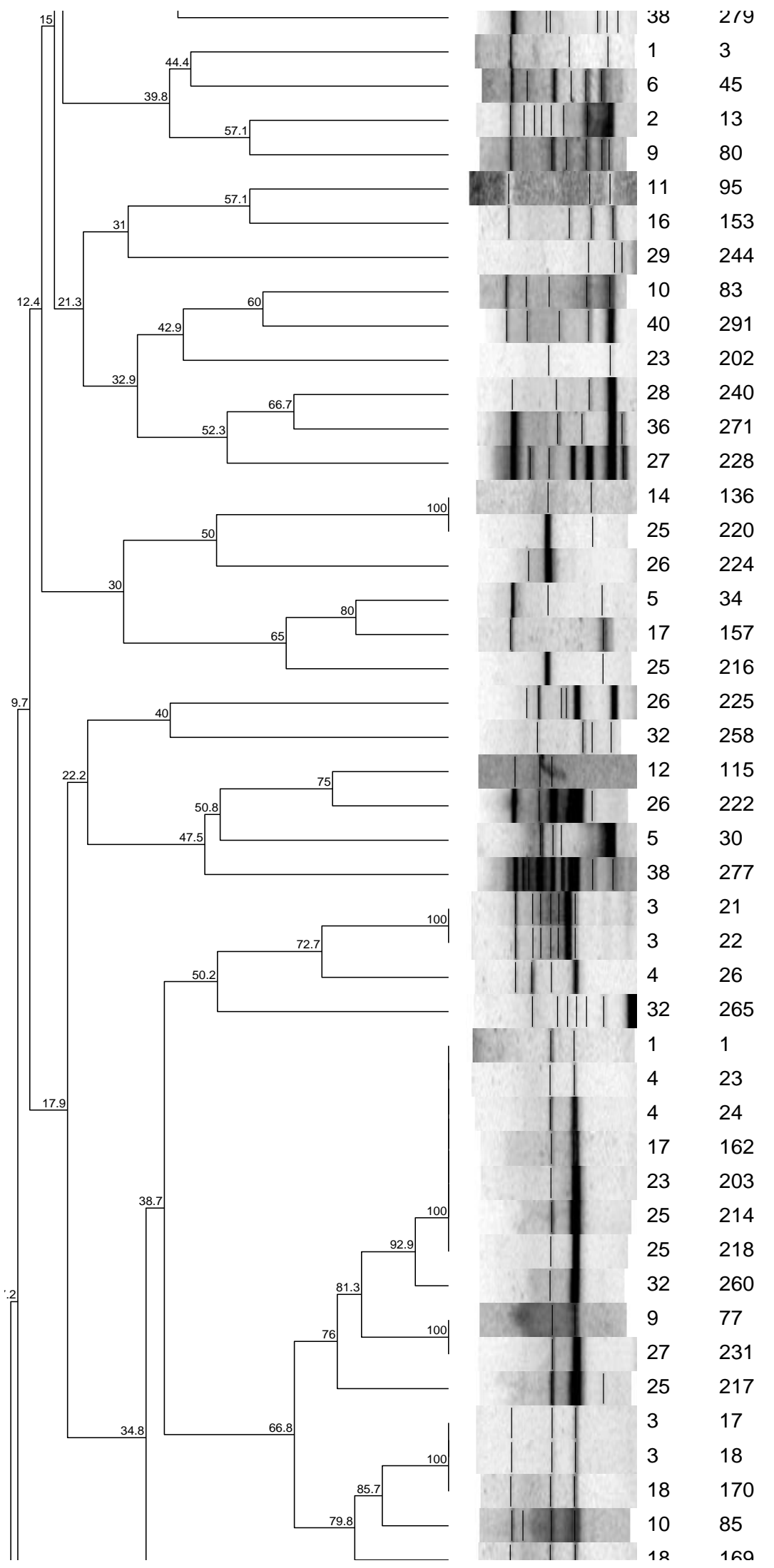

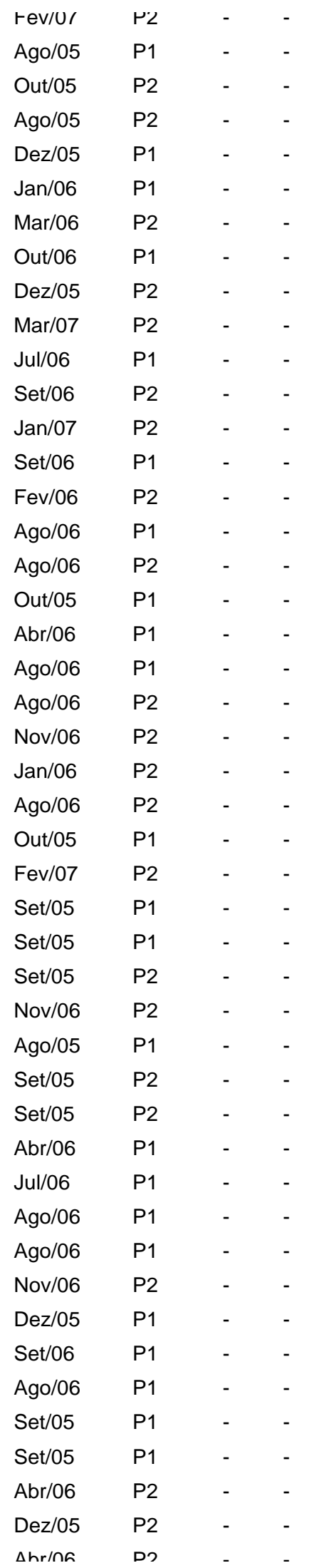

Figura 17 - Dendrograma construído pelo programa BioNumerics para a técnica de ERIC-PCR, usando o coeficiente de Dice, com as bactérias marinhas. 

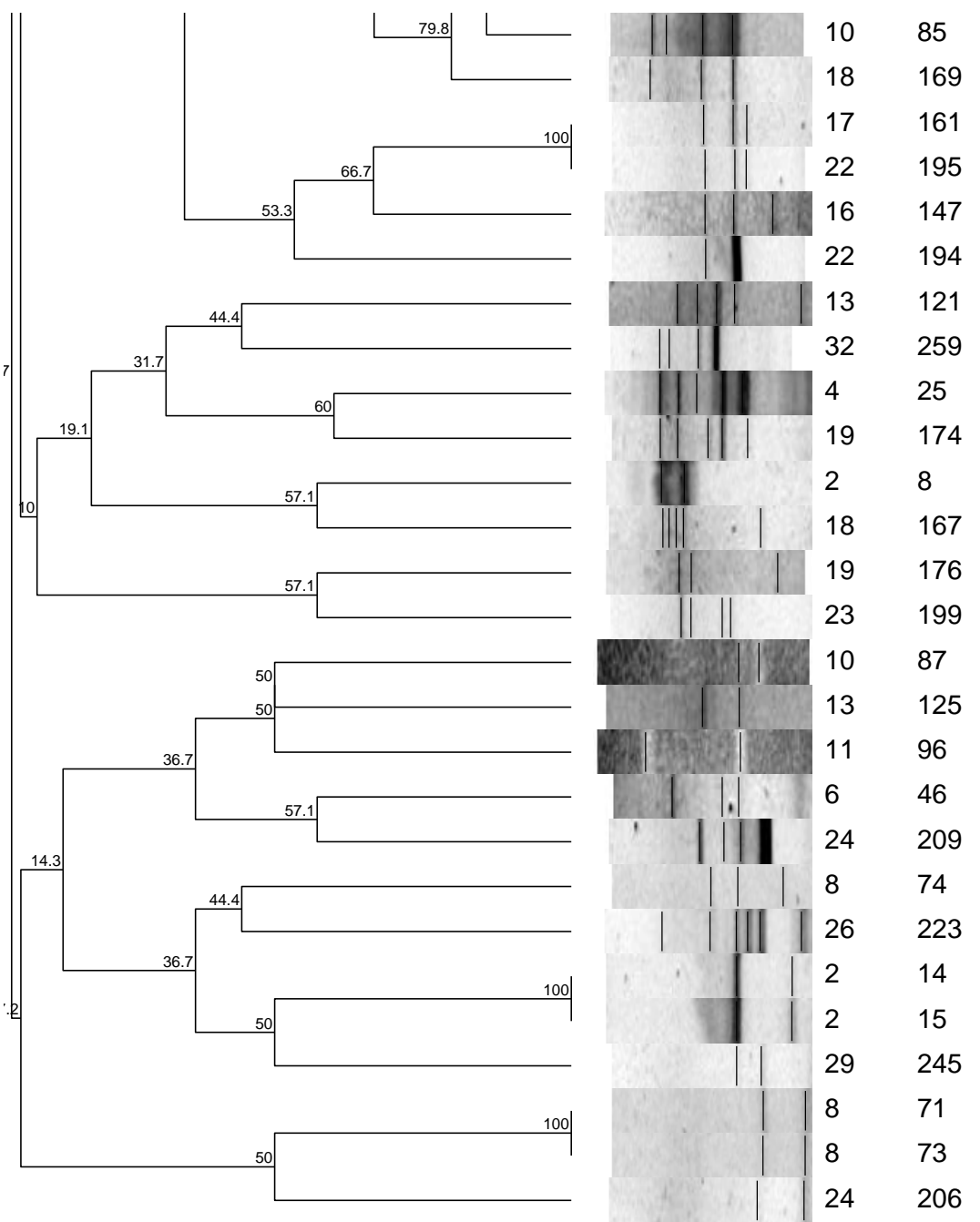

$\begin{array}{llll}\text { Dez/05 } & \text { P2 } & - & - \\ \text { Abr/06 } & \text { P2 } & - & - \\ \text { Abr/06 } & \text { P1 } & - & - \\ \text { Jun/06 } & \text { P2 } & - & - \\ \text { Mar/06 } & \text { P2 } & - & - \\ \text { Jun/06 } & \text { P2 } & - & - \\ \text { Fev/06 } & \text { P1 } & - & - \\ \text { Nov/06 } & \text { P2 } & - & - \\ \text { Set/05 } & \text { P2 } & - & - \\ \text { Mai/06 } & \text { P1 } & - & - \\ \text { Ago/05 } & \text { P2 } & - & - \\ \text { Abr/06 } & \text { P2 } & - & - \\ \text { Mai/06 } & \text { P1 } & - & - \\ \text { Jul/06 } & \text { P1 } & - & - \\ \text { Dez/05 } & \text { P2 } & - & - \\ \text { Fev/06 } & \text { P1 } & - & - \\ \text { Jan/06 } & \text { P1 } & - & - \\ \text { Out/05 } & \text { P2 } & - & - \\ \text { Jul/06 } & \text { P2 } & - & - \\ \text { Nov/05 } & \text { P2 } & - & + \\ \text { Ago/06 } & \text { P2 } & - & - \\ \text { Ago/05 } & \text { P2 } & - & - \\ \text { Ago/05 } & \text { P2 } & - & - \\ \text { Out/06 } & \text { P1 } & - & - \\ \text { Nov/05 } & \text { P2 } & - & - \\ \text { Nov/05 } & \text { P2 } & - & - \\ \text { Jul/06 } & \text { P2 } & - & - \\ & & & -\end{array}$

Figura 17 - Dendrograma construído pelo programa BioNumerics para a técnica de ERIC-PCR, usando o coeficiente de Dice, com as bactérias marinhas.

Como foi mostrado nas análises de agrupamento das técnicas de BOX-PCR e ERICPCR que a maioria dos perfis gerados por estes fingerprintings foram bem diversificados e que somente 35 e 34 isolados bacterianos, respectivamente, obtiveram perfis semelhantes ( $100 \%$ de similaridade) e, que destes somente 4 isolados (22 e $23 ; 40$ e 41 ) deram $100 \%$ de similaridade por ambas as técnicas, concluímos que estas técnicas não permitiram realizar uma triagem para, assim, diminuir o número de isolados e serem seqüenciados.

Portanto, utilizando essas técnicas de tipagem não podemos dizer que os isolados agrupados em cada cluster ou subclusters, tanto para a técnica de BOX-PCR como para a de ERIC-PCR têm características comuns ou pertencem a um mesmo grupo, por isso foi necessário submetê-los ao seqüenciamento. 


\subsubsection{Seqüenciamento parcial da região 16S rRNA dos isolados bacterianos}

De acordo com os resultados que foram encontrados nas análises de agrupamento das técnicas acima, todos os 240 isolados bacterianos gram-negativos foram submetidos à amplificação da região 16S rRNA. No entanto, 19 isolados não amplificaram mesmo depois de três tentativas de amplificação e 18 isolados não estavam de acordo com a concentração mínima recomendada pelo Centro do Genoma Humano/USP que é de, no mínimo, $40 \mathrm{ng} / \mu \mathrm{L}$ de PCR purificada para produtos que possuem 1500 bp. Por esse motivo, essas amostras não foram submetidas ao seqüenciamento.

Foi realizado o seqüenciamento parcial do gene 16S rRNA de 203 isolados pertencentes ao grupo de bactérias gram-negativas utilizando o iniciador 1041R. Os cromatogramas resultantes de cada um dos sequienciamentos foram analisados no programa BioEdit e, com isso verificou-se que 35 sequiências apresentaram-se ruins, as quais foram excluídas das análises posteriores.

As 168 sequiências de DNA que tiveram sequiências de boa qualidade, após análise de seus cromatogramas, foram editadas, onde as extremidades com baixa qualidade foram removidas e alinhadas no programa BioEdit. Após edição, as seqüências com $\geq 97 \%$ de identidade foram agrupadas e somente uma sequência foi escolhida para representar o grupo. No total, 18 sequiências foram utilizadas para representar as bactérias marinhas (Tabela 3). 
Tabela 3 - Representantes dominantes das bactérias marinhas encontradas nas amostras de água do mar coletadas no Canal de São Sebastião.

\begin{tabular}{|c|c|c|c|c|}
\hline Classe & Representante & $\begin{array}{c}\text { № de sequências } \\
\text { de Bactérias } \\
\text { Marinhas }\end{array}$ & Linhagem tipo mais próxima (\%)* & $\begin{array}{l}\text { № de acesso da } \\
\text { linhagem tipo mais } \\
\text { próxima }\end{array}$ \\
\hline \multirow{14}{*}{ 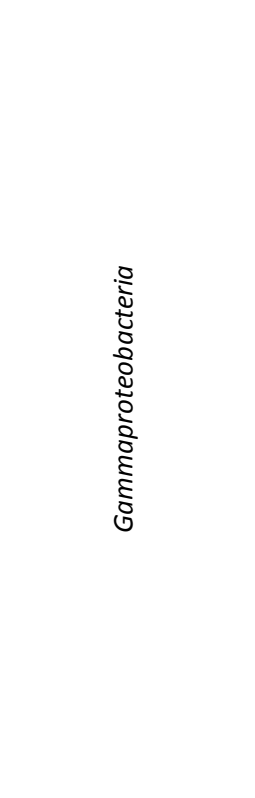 } & BMV1-SS & 136 & Vibrio ponticus (T); CECT $5869(99,6)$ & AJ630103 \\
\hline & BMV5-SS & 8 & Vibrio chagasii $(\mathrm{T})$; R-3712 $(99,6)$ & AJ316199 \\
\hline & BMV13-SS & 1 & Vibrio rumoiensis (T); S-1 $(99,2)$ & AB013297 \\
\hline & BMV151-SS & 1 & Vibrio xuii (T); R-15052 $(98,2)$ & AJ316181 \\
\hline & BMV200-SS & 1 & Vibrio coralliilyticus (T); LMG $20984(97,6)$ & AJ440005 \\
\hline & BMV265-SS & 1 & Vibrio neptunius (T); LMG $20536(99,2)$ & AJ316171 \\
\hline & BMV164-SS & 4 & Photobacterium eurosenbergii (T); LMG 22227 (100) & AJ842346 \\
\hline & BMV2-SS & 1 & Photobacterium damselae subsp. damselae (T); ATCC $33539(99,8)$ & AB032015 \\
\hline & BMV25-SS & 1 & Aeromonas enteropelogenes (T); ATCC 49657 (100) & $x 60415$ \\
\hline & BMV171-SS & 1 & Shewanella algae (T); ATCC $51192(98,8)$ & AF005249 \\
\hline & BMV234-SS & 1 & Pseudoalteromonas issachenkonii (T); KMM $3549(98,8)$ & AF316144 \\
\hline & BMV263-SS & 1 & Alteromonas marina $(\mathrm{T})$; SW-47 $(99,2)$ & AF529060 \\
\hline & BMV129-SS & 1 & Alteromonas macleodii (T); DSM $6062(98,6)$ & Y18228 \\
\hline & BMV14-SS & 4 & Pseudomonas mosselii (T); CIP $105259(99,8)$ & AF072688 \\
\hline \multirow[t]{2}{*}{ Betaproteobacteria } & BMV7-SS & 1 & $\begin{array}{c}\text { Alcaligenes faecalis subsp. faecalis }(\mathrm{T})(98,2) / \\
\text { Alcaligenes faecalis subsp. faecalis }(98,4)\end{array}$ & M22508 / AJ277669 \\
\hline & BMV253-SS & 1 & Paracoccus haeundaensis (T); BC74171 $(92,9)$ & AY189743 \\
\hline \multirow[t]{2}{*}{ Alphaproteobacteria } & BMV71-SS & 1 & Thalassobius mediterraneus $(\mathrm{T}) ;$ CECT $5383=\mathrm{XSM} 19(99,6)$ & AJ878874 \\
\hline & BMV126-SS & 3 & Yangia pacifica $(T)$; DX5-10 $(98,4)$ & AJ877265 \\
\hline
\end{tabular}

$3 \quad 18 \quad 168$

* Cada sequência representante foi utilizada para calcular a similaridade com a linhagem tipo (T).

Cada sequência representante foi comparada com seqüências disponibilizadas no banco de dados do RDP II e uma árvore filogenética foi construída com a utilização do programa MEGA 4, através do método de Neighbor-Joining, modelo de substituição de nucleotídeos por Jukes-Cantor e valor de bootstrap de 1000 repetições (Figura 18). 


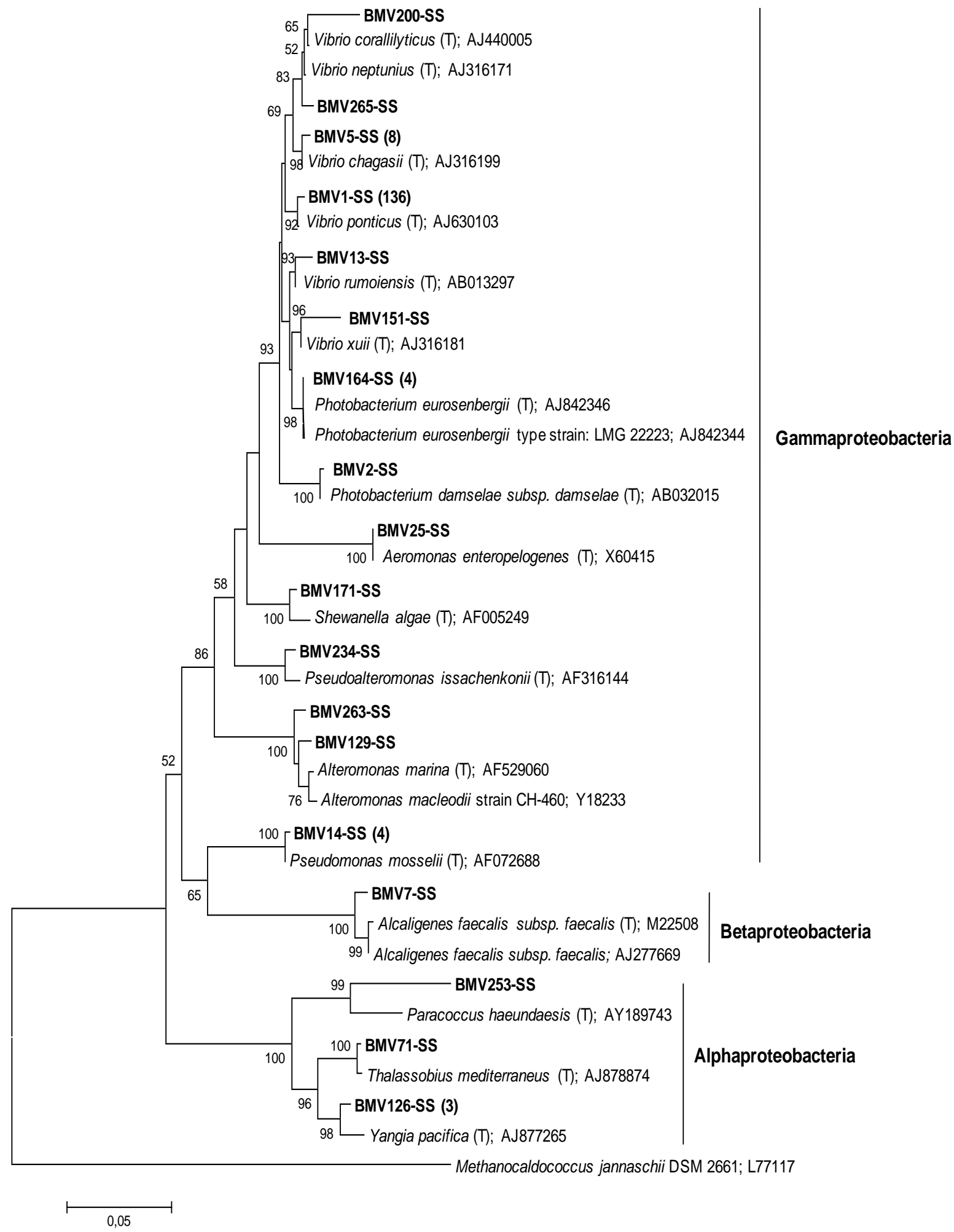

Figura 18 - Árvore filogenética com as 18 seqüências que representam os isolados de bactérias marinhas, juntamente com as seqüências de linhagem tipo e/ou seqüências referência. A sequência Methanocaldococcus jannaschii foi utilizada como grupo externo para enraizamento da árvore. Somente os valores de bootstrap que estavam acima de 50 foram mostrados. BMV...-SS: representantes das bactérias marinhas viáveis do Canal de São Sebastião; ( ): número de seqüências com identidade $\geq 97 \%$. 
De acordo com o agrupamento das seqüências mostrados na árvore filogenética verificou-se que os 168 isolados de bactérias marinhas pertencem ao filo Proteobacteria e, dentro desse filo, foi possível distribuí-los nas classes $\alpha$-, $\beta$ - e $\gamma$-proteobacteria com as seguintes prevalências: 5, 1 e 162 isolados, respectivamente (Figura 19).

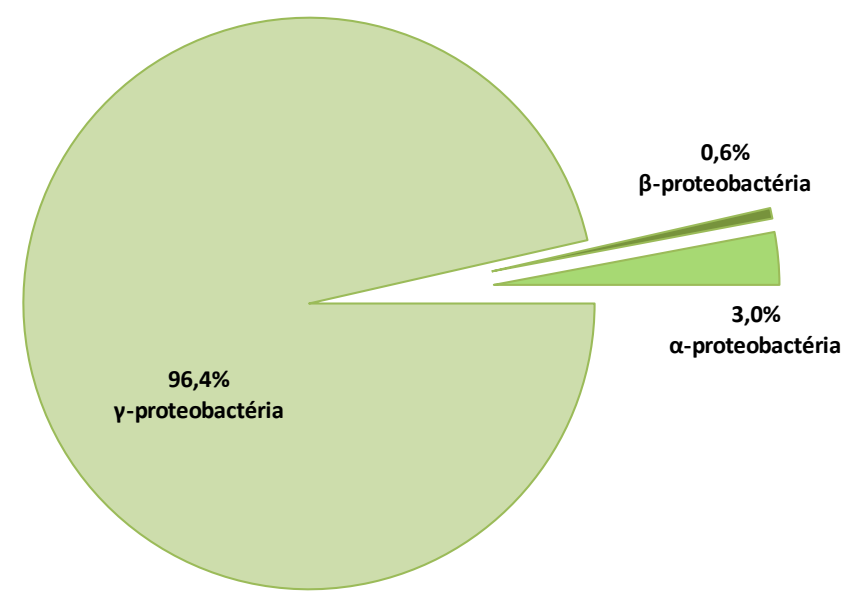

Figura 19 - Distribuição dos 168 isolados dentro da classe Proteobacteria.

Os isolados pertencentes às classes das proteobactérias foram classificados em 11 gêneros diferentes mostrados a seguir e na figura 20 :

1) a-proteobacteria: Paracoccus sp. $(\mathrm{n}=1)$, Thalassobius sp. $(\mathrm{n}=1)$ e Yangia $\mathrm{sp}(\mathrm{n}=3)$;

2) $\beta$-proteobacteria: Alcaligenes sp. $(\mathrm{n}=1)$;

3) r-proteobacteria: Vibrio sp. $(\mathrm{n}=148)$, Photobacterium sp. $(\mathrm{n}=5)$, Aeromonas $\mathrm{sp} .(\mathrm{n}=1)$, Shewanella sp. $(\mathrm{n}=1)$, Pseudoalteromonas sp. $(\mathrm{n}=1)$, Alteromonas $\mathrm{sp} .(\mathrm{n}=2)$, Pseudomonas sp. $(\mathrm{n}=4)$.

Considerando as 3 classes, verificamos que a $\beta$-proteobacteria foi encontrada com menor freqüência e, ao mesmo tempo, com menor número de representantes sendo este representado por apenas 1 isolado do gênero Alcaligenes. Embora na classe $\alpha$-proteobacteria tenha sido encontrado 5 isolados que pertenciam a 3 gêneros distintos, esta classe também foi encontrada com baixa freqüência (3\%), levando-se em conta o número total de isolados seqüenciados. Em contrapartida, a classe $\gamma$-proteobacteria além de apresentar o maior número de isolados também foi a que apresentou o maior número de gêneros diferentes $(n=7)$. Por 
outro lado, embora o número de gêneros tenha sido maior, a grande parte dos isolados $(\mathrm{n}=$ 148) pertence ao gênero Vibrio (Figura 20).

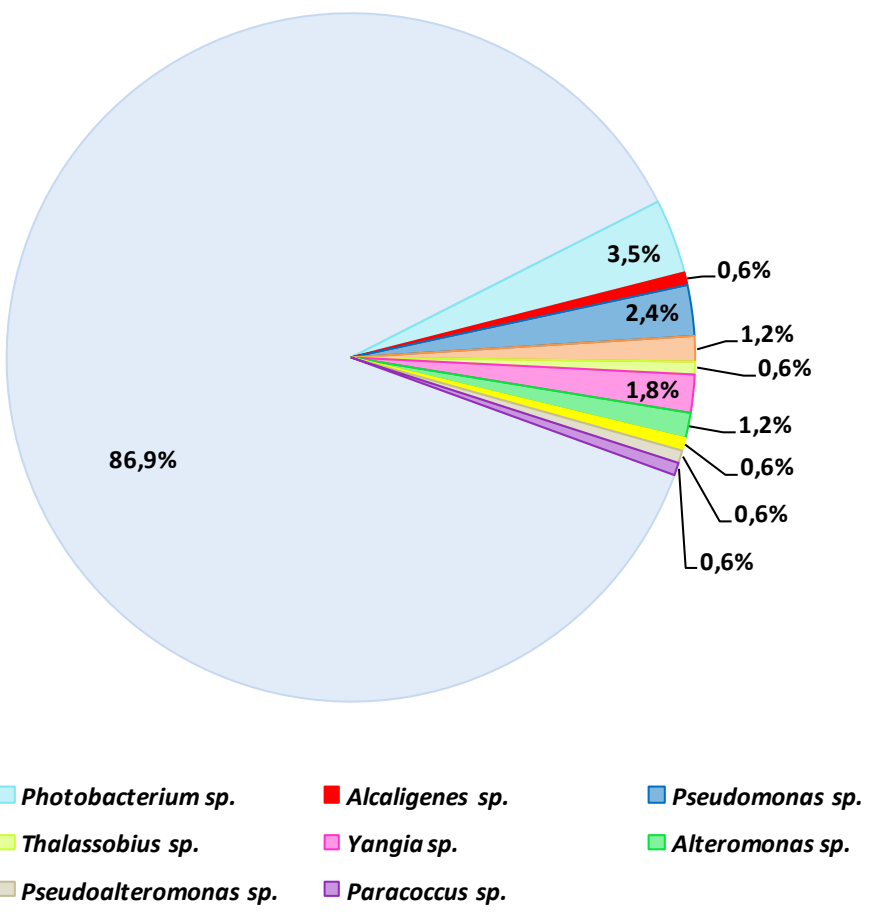

Figura 20 - Freqüência dos 11 gêneros identificados pelo seqüenciamento parcial da região $16 \mathrm{~S}$ de bactérias marinhas em amostras de água do mar coletadas no Canal de São Sebastião.

Nessa análise geral, de todas as seqüências de bactérias marinhas seqüenciadas, foi verificado que, apesar dos 168 isolados terem sido distribuídos em 11 gêneros distintos, a maioria $(\sim 87 \%)$ pertence ao gênero Vibrio. A lista completa de todas as bactérias marinhas seqüenciadas, com suas identificações e suas similaridades com seqüências depositadas no banco de dados pode ser vista no Anexo C.

Adicionalmente, partimos para uma análise mais detalhada para verificar a distribuição desses gêneros ao longo dos 20 meses de estudo, já que um dos objetivos desse trabalho é verificar não só a diversidade bacteriana no Canal de São Sebastião como também conhecer a sua distribuição sazonal. Diante disso, é importante lembrar, que o número de bactérias marinhas não foi constante ao longo dos 20 meses e, conseqüentemente, a porcentagem de distribuição mensal também variou (Figuras 21 e 22).

É interessante destacar, que o gênero Vibrio foi isolado em todos os 20 meses de coleta, com exceção de dezembro/2006, mês em que não foi isolada nenhuma bactéria gramnegativa e mesmo em meses em que poucas bactérias marinhas foram isoladas, estas eram do 
gênero Vibrio, como, por exemplo, no caso dos meses de maio, junho e outubro/2006 e janeiro/2007. Com isso, foi verificada uma alta prevalência desse gênero ao longo dos 20 meses.

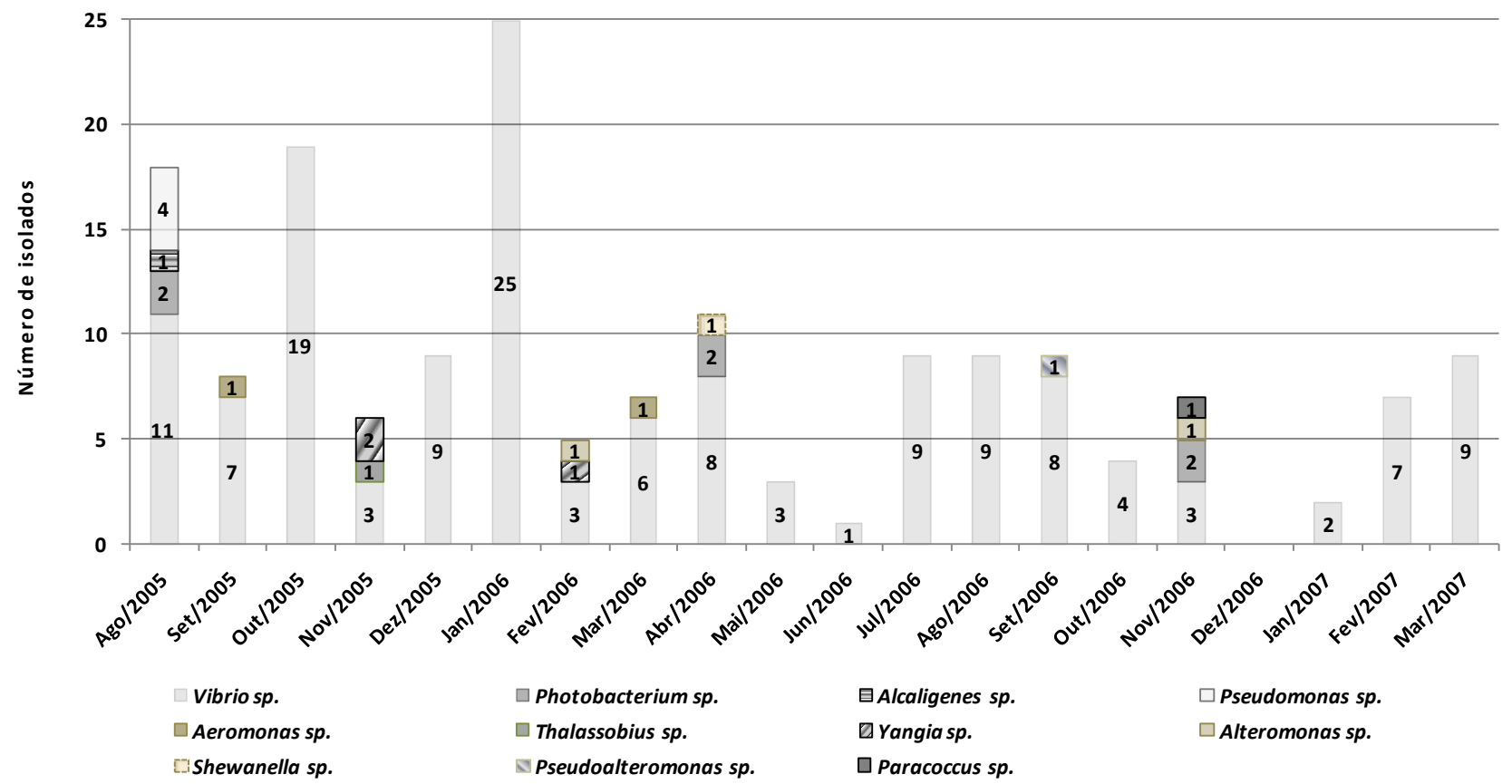

Figura 21 - Distribuição mensal dos gêneros identificados pelo seqüenciamento parcial da região 16S de bactérias marinhas em amostras de água do mar coletadas no Canal de São Sebastião. Nota: Os números dentro de cada barra referem-se ao número de bactérias marinhas seqüenciadas.

Nos meses de agosto/2005 e novembro/2006 foi apresentada a maior diversidade de gêneros $(n=4)$ e dois desses gêneros (Vibrio sp. e Photobacterium sp.) apareceram nos dois meses mencionados, seguidos pelos meses de novembro/2005, fevereiro/2006 e abril/2006, onde cada um apresentou três gêneros, dos quais dois (Vibrio sp. e Yangia sp.) também se repetiram. No que se refere à freqüência dos isolados, mais uma vez devemos enfatizar que mais de 50\% dos isolados mensais estavam dentro do gênero Vibrio, com exceção do mês de novembro/2006, onde somente $43 \%$ dos isolados pertenciam a este gênero (Figura 22).

Durante os 20 meses, dois períodos mensais se repetiram em anos diferentes: agostodezembro/2005 e 2006, além de janeiro-março/2006 e 2007. Se levarmos em consideração essas duas épocas em anos consecutivos, foi verificado que o primeiro período mencionado, referente ao final do verão e início do inverno, foi o que apresentou maior diversidade de gêneros mensais $(\mathrm{n}=4)$. No entanto, cabe mencionar que novamente os gêneros Vibrio e Photobacterium aparecem nesse período. 
Já no segundo período mencionado (janeiro-março/2006 e 2007) pôde-se verificar que no primeiro ano houve maior diversidade, onde quatro gêneros foram encontrados (Vibrio sp., Yangia sp., Alteromonas sp. e Aeromonas sp.), enquanto que no ano de 2007 somente o gênero Vibrio foi observado.

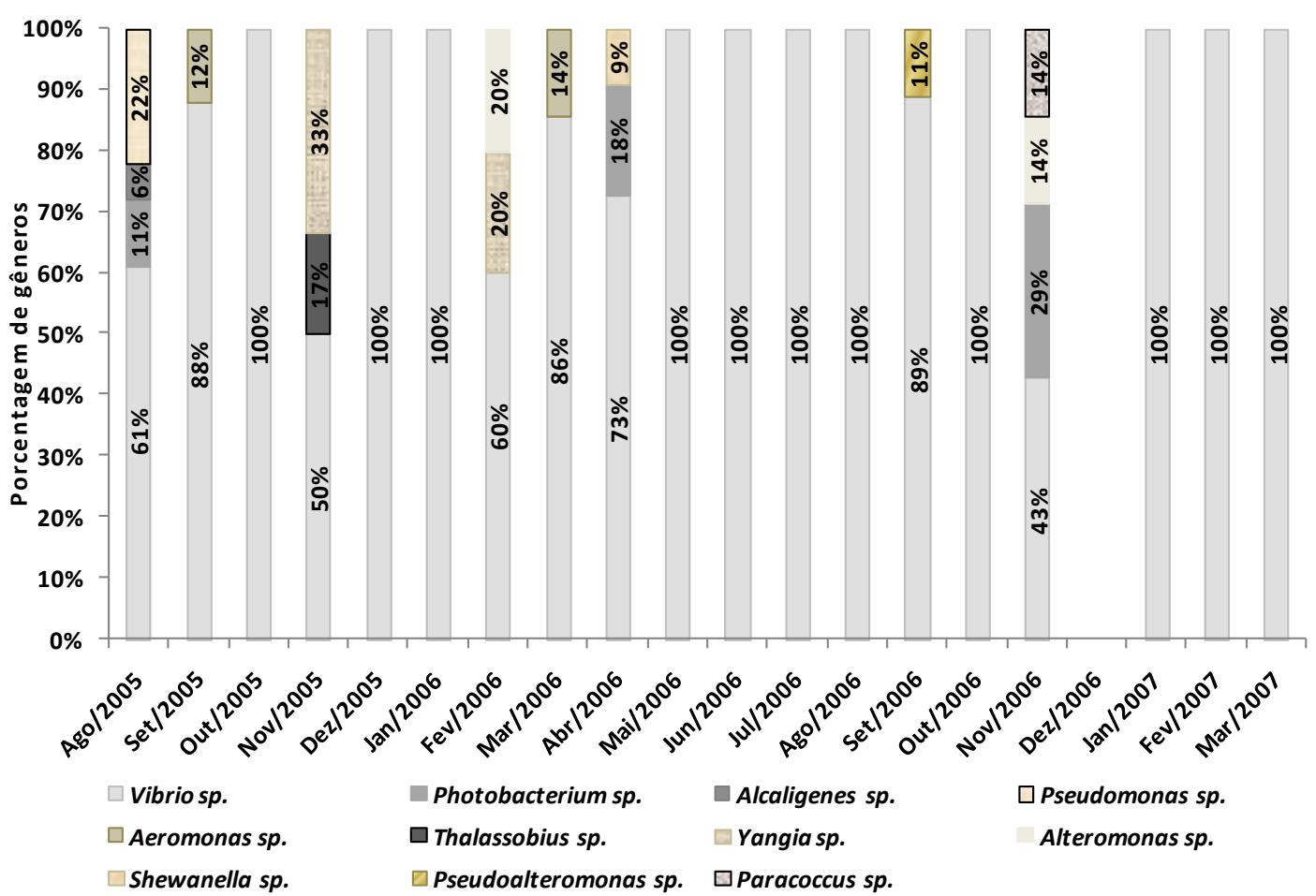

Figura 22 - Freqüência mensal dos gêneros identificados pelo seqüenciamento parcial da região 16S de bactérias marinhas em amostras de água do mar coletadas no Canal de São Sebastião.

Após identificação destes 168 isolados, por seqüenciamento parcial do gene $16 \mathrm{~S}$ rDNA, um novo dendrograma para as técnicas de BOX-PCR e ERIC-PCR foi construído com essas amostras para verificar se os agrupamentos gerados possuíam relação com os resultados de seqüenciamento, já que os clusters formados anteriormente (itens 5.4.2.1 e 5.4.2.2) não tiveram características comuns.

Os mesmos padrões utilizados na etapa acima foram levados em consideração para analisar os novos dendrogramas, ou seja, os isolados de bactérias marinhas que amplificaram somente 1 banda (7 para a técnica de BOX-PCR e 43 para a de ERIC-PCR) e os que não apresentaram produtos de amplificação (3 para a técnica de BOX-PCR e 32 para a de ERICPCR) foram desconsiderados no momento da construção dos dendrogramas. Além disso, deve-se observar que dois isolados bacterianos (39 e 41) não amplificaram inicialmente 
utilizando-se essas duas técnicas. No entanto, amplificaram a região $16 \mathrm{~S}$ rRNA e foram seqüenciados.

Após a exclusão dos isolados citados acima, o dendrograma construído com a técnica de BOX-PCR mostra os agrupamentos de 94\% $(\mathrm{n}=156)$ dos isolados que foram seqüenciados (Figura 23).

A análise do dendrograma obtido pela técnica de BOX-PCR nos permitiu observar que existiu uma similaridade de 7,4\% entre as 156 bactérias marinhas. Foram identificados basicamente 33 clusters com similaridade maior que 70\%, onde 2 apresentaram $100 \%$ de similaridade. Além desses últimos, pôde-se observar mais 10 subclusters com $100 \%$ de similaridade.

Entre estes clusters e subclusters com $100 \%$ de similaridade $83,4 \%(\mathrm{n}=10)$ foram formados por isolados do gênero Vibrio, 1 cluster foi formado pelo agrupamento de dois isolados do gênero Pseudomonas e 1 cluster pelo agrupamento de dois isolados de gêneros diferentes: Vibrio sp. e Thalassobius sp.

Levando em consideração a similaridade $\geq 70 \%$, foi possível verificar 26 clusters, dos quais 23 foram formados apenas por bactérias do gênero Vibrio e três foram formados entre os agrupamentos dos gêneros Vibrio sp. e Photobacterium sp. (85,7\% de similaridade), Vibrio sp. e Yangia sp. (80\% de similaridade) e Vibrio sp. e Aeromonas sp. (75\% de similaridade).

Com exceção dos isolados dos gêneros Vibrios e Pseudomonas mencionados acima, nenhum outro isolado que foi identificado como sendo do mesmo gênero (Alteromonas sp., Photobacterium sp. e Yangia sp.) foi agrupado com 100\% de similaridade. Vale mencionar, que a exceção também foi feita para todos os outros isolados do gênero Vibrio.

Diante disso, mesmo que os isolados tenham sido identificados pelo seqüenciamento parcial do gene 16S rDNA, a maioria dos agrupamentos gerados pela técnica de BOX-PCR não foram formados apenas por isolados do mesmo de gênero e nem por características sazonais semelhantes. 


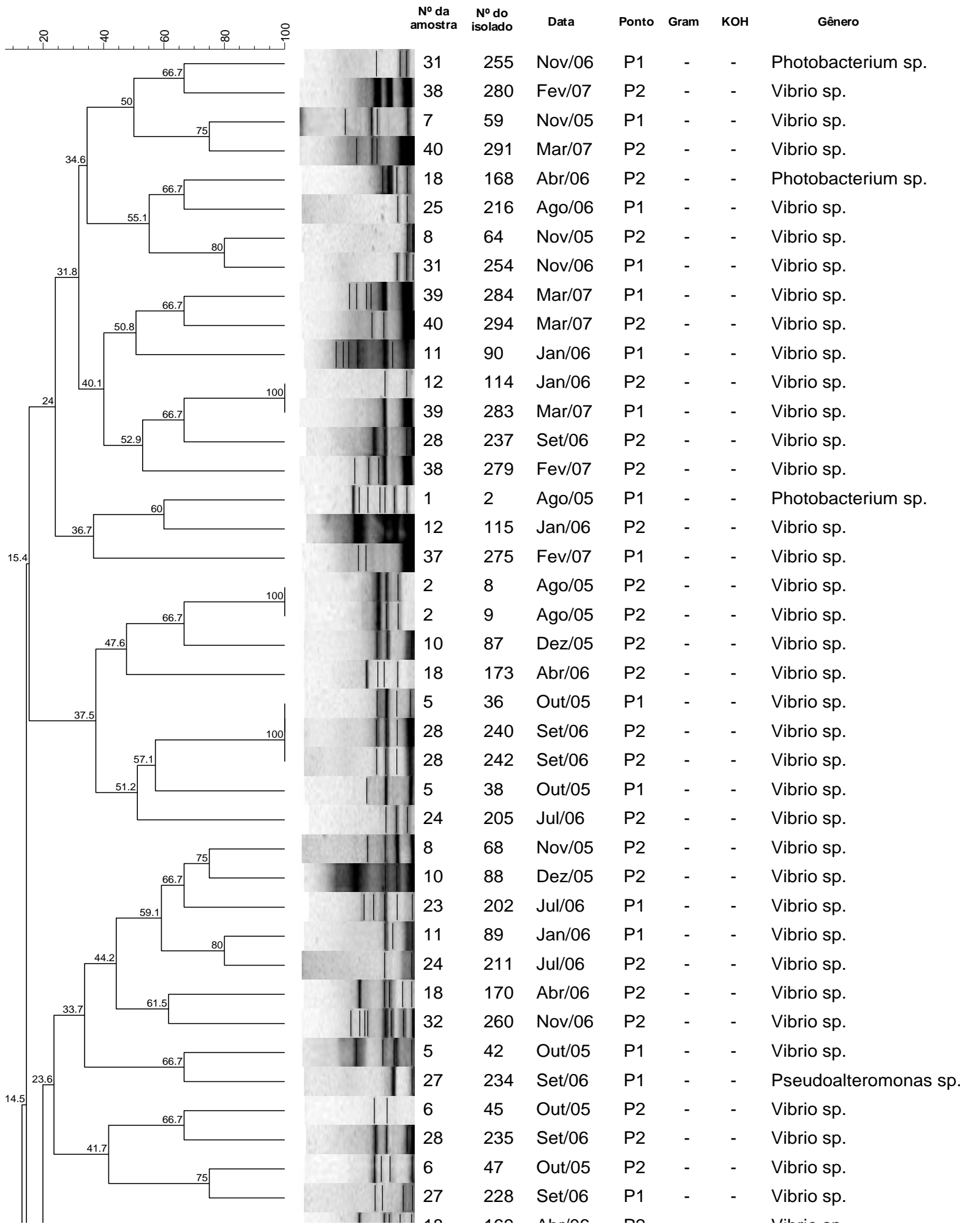

Figura 23 - Dendrograma construído pelo programa BioNumerics para a técnica de BOX-PCR, usando o coeficiente de Dice, com as bactérias marinhas identificadas pelo seqüenciamento parcial da região $16 \mathrm{~S}$ rRNA. 


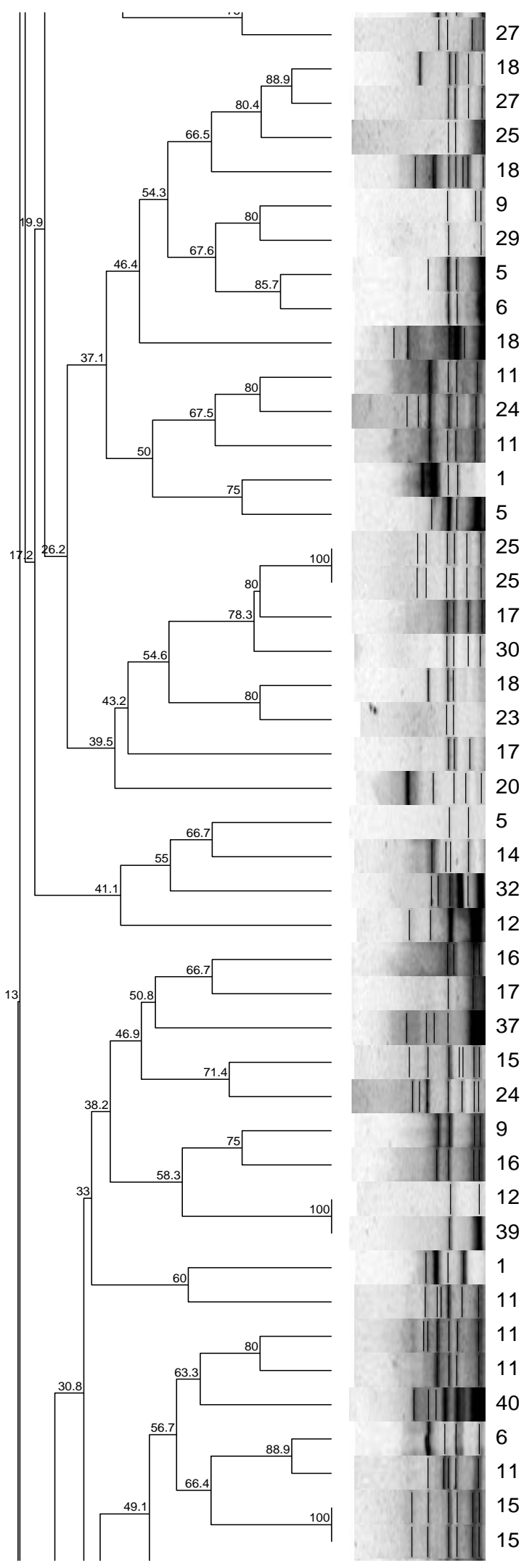

\begin{tabular}{|c|c|c|c|c|c|}
\hline 228 & Set/06 & $\mathrm{P} 1$ & - & - & Vibrio sp. \\
\hline 169 & Abr/06 & $\mathrm{P} 2$ & - & - & Vibrio sp. \\
\hline 231 & Set/06 & $\mathrm{P} 1$ & - & - & Vibrio sp. \\
\hline 214 & Ago/06 & $\mathrm{P} 1$ & - & - & Vibrio sp. \\
\hline 164 & Abr/06 & $\mathrm{P} 2$ & - & - & Photobacterium sp. \\
\hline 79 & Dez/05 & $\mathrm{P} 1$ & - & - & Vibrio sp. \\
\hline 246 & Out/06 & $\mathrm{P} 1$ & - & - & Vibrio sp. \\
\hline 44 & Out/05 & $\mathrm{P} 1$ & - & - & Vibrio sp. \\
\hline 48 & Out/05 & $\mathrm{P} 2$ & - & - & Vibrio sp. \\
\hline 171 & Abr/06 & $\mathrm{P} 2$ & - & - & Shewanella sp. \\
\hline 95 & Jan/06 & $\mathrm{P} 1$ & - & - & Vibrio sp. \\
\hline 209 & Jul/06 & $\mathrm{P} 2$ & - & - & Vibrio sp. \\
\hline 93 & Jan/06 & $\mathrm{P} 1$ & - & - & Vibrio sp. \\
\hline 5 & Ago/05 & $\mathrm{P} 1$ & - & - & Vibrio sp. \\
\hline 33 & Out/05 & $\mathrm{P} 1$ & - & - & Vibrio sp. \\
\hline 217 & Ago/06 & $\mathrm{P} 1$ & - & - & Vibrio sp. \\
\hline 218 & Ago/06 & $\mathrm{P} 1$ & - & - & Vibrio sp. \\
\hline 158 & Abr/06 & $\mathrm{P} 1$ & - & - & Vibrio sp. \\
\hline 249 & Out/06 & $\mathrm{P} 2$ & - & - & Vibrio sp. \\
\hline 167 & Abr/06 & $\mathrm{P} 2$ & - & - & Vibrio sp. \\
\hline 198 & Jul/06 & $\mathrm{P} 1$ & - & - & Vibrio sp. \\
\hline 162 & Abr/06 & $\mathrm{P} 1$ & - & - & Vibrio sp. \\
\hline 177 & Mai/06 & $\mathrm{P} 2$ & - & - & Vibrio sp. \\
\hline 28 & Out/05 & $\mathrm{P} 1$ & - & - & Vibrio sp. \\
\hline 129 & $\mathrm{Fev} / 06$ & $\mathrm{P} 2$ & - & - & Alteromonas sp. \\
\hline 265 & Nov/06 & $\mathrm{P} 2$ & - & - & Vibrio sp. \\
\hline 112 & Jan/06 & $\mathrm{P} 2$ & - & - & Vibrio sp. \\
\hline 151 & Mar/06 & P2 & - & - & Vibrio sp. \\
\hline 157 & Abr/06 & $\mathrm{P} 1$ & - & - & Vibrio sp. \\
\hline 273 & $\mathrm{Fev} / 07$ & $\mathrm{P} 1$ & - & - & Vibrio sp. \\
\hline 138 & Mar/06 & $\mathrm{P} 1$ & - & - & Vibrio sp. \\
\hline 208 & Jul/06 & $\mathrm{P} 2$ & - & - & Vibrio sp. \\
\hline 80 & Dez/05 & $\mathrm{P} 1$ & - & - & Vibrio sp. \\
\hline 152 & Mar/06 & $\mathrm{P} 2$ & - & - & Vibrio sp. \\
\hline 113 & Jan/06 & $\mathrm{P} 2$ & - & - & Vibrio sp. \\
\hline 282 & Mar/07 & $\mathrm{P} 1$ & - & - & Vibrio sp. \\
\hline 1 & Ago/05 & $\mathrm{P} 1$ & - & - & Vibrio sp. \\
\hline 97 & Jan/06 & $\mathrm{P} 1$ & - & - & Vibrio sp. \\
\hline 96 & Jan/06 & $\mathrm{P} 1$ & - & - & Vibrio sp. \\
\hline 98 & Jan/06 & $\mathrm{P} 1$ & - & - & Vibrio sp. \\
\hline 293 & Mar/07 & P2 & - & - & Vibrio sp. \\
\hline 46 & Out/05 & $\mathrm{P} 2$ & - & - & Vibrio sp. \\
\hline 94 & Jan/06 & $\mathrm{P} 1$ & - & - & Vibrio sp. \\
\hline 139 & Mar/06 & $\mathrm{P} 1$ & - & - & Vibrio sp. \\
\hline 140 & Mar/06 & P1 & - & - & Vibrio sp. \\
\hline
\end{tabular}

Figura 23 - Dendrograma construído pelo programa BioNumerics para a técnica de BOX-PCR, usando o coeficiente de Dice, com as bactérias marinhas identificadas pelo seqüenciamento parcial da região $16 \mathrm{~S}$ rRNA. 

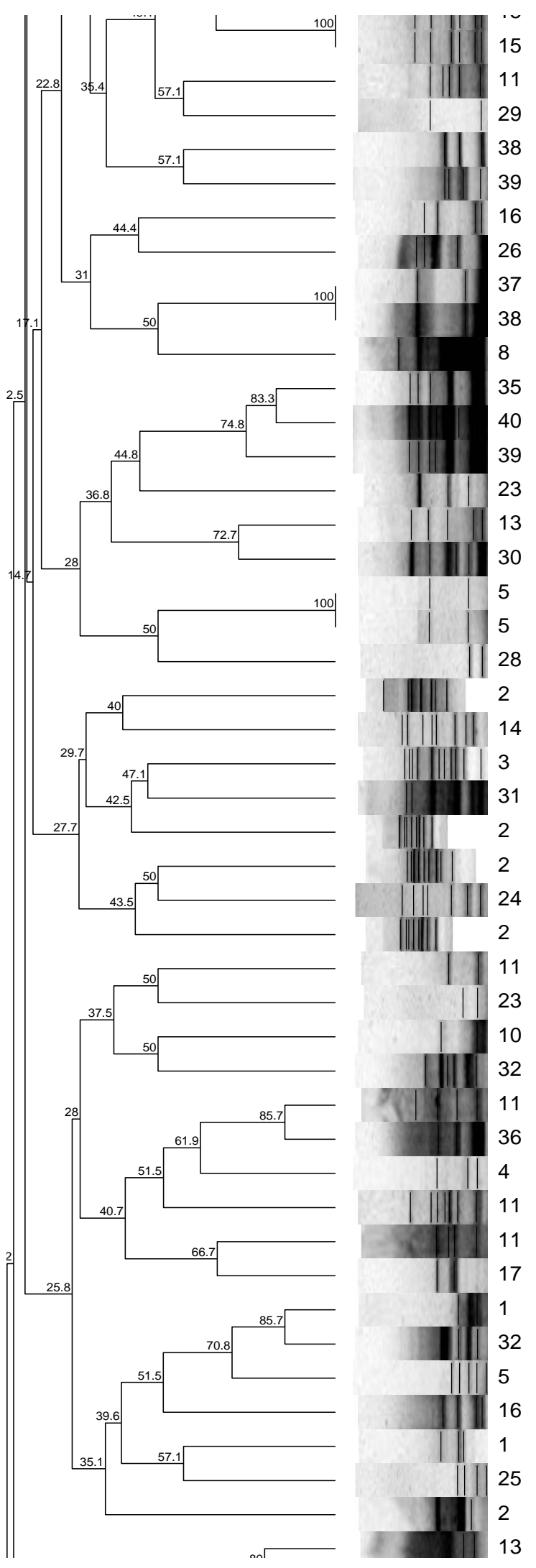

\begin{tabular}{|c|c|c|c|c|c|}
\hline$\cdots$ & ...nu, & $\cdots$ & & & $\cdots$. \\
\hline 140 & Mar/06 & P1 & - & - & Vibrio sp. \\
\hline 99 & Jan/06 & $\mathrm{P} 1$ & - & - & Vibrio sp. \\
\hline 245 & Out/06 & $\mathrm{P} 1$ & - & - & Vibrio sp. \\
\hline 278 & $\mathrm{Fev} / 07$ & P2 & - & - & Vibrio sp. \\
\hline 289 & Mar/07 & $\mathrm{P} 1$ & - & - & Vibrio sp. \\
\hline 153 & Mar/06 & P2 & - & - & Vibrio sp. \\
\hline 225 & Ago/06 & P2 & - & - & Vibrio sp. \\
\hline 274 & $\mathrm{Fev} / 07$ & $\mathrm{P} 1$ & - & - & Vibrio sp. \\
\hline 277 & $\mathrm{Fev} / 07$ & $\mathrm{P} 2$ & - & - & Vibrio sp. \\
\hline 74 & Nov/05 & $\mathrm{P} 2$ & - & + & Yangia sp. \\
\hline 269 & Jan/07 & $\mathrm{P} 1$ & - & - & Vibrio sp. \\
\hline 292 & Mar/07 & $\mathrm{P} 2$ & - & - & Vibrio sp. \\
\hline 290 & Mar/07 & $\mathrm{P} 1$ & - & - & Vibrio sp. \\
\hline 203 & Jul/06 & $\mathrm{P} 1$ & - & - & Vibrio sp. \\
\hline 119 & $\mathrm{Fev} / 06$ & P1 & - & - & Vibrio sp. \\
\hline 252 & Out/06 & $\mathrm{P} 2$ & - & - & Vibrio sp. \\
\hline 40 & Out/05 & P1 & - & - & Vibrio sp. \\
\hline 41 & Out/05 & $\mathrm{P} 1$ & - & - & Vibrio sp. \\
\hline 236 & Set/06 & P2 & - & - & Vibrio sp. \\
\hline 14 & Ago/05 & P2 & - & - & Pseudomonas sp. \\
\hline 133 & $\mathrm{Fev} / 06$ & P2 & - & - & Vibrio sp. \\
\hline 18 & Set/05 & $\mathrm{P} 1$ & - & - & Vibrio sp. \\
\hline 253 & Nov/06 & $\mathrm{P} 1$ & - & + & Paracoccus sp \\
\hline 11 & Ago/05 & P2 & - & - & Vibrio sp. \\
\hline 15 & Ago/05 & P2 & - & - & Pseudomonas sp. \\
\hline 210 & Jul/06 & P2 & - & - & Vibrio sp. \\
\hline 12 & Ago/05 & P2 & - & - & Vibrio sp. \\
\hline 100 & Jan/06 & $\mathrm{P} 1$ & - & - & Vibrio sp. \\
\hline 201 & $\mathrm{Jul} / 06$ & $\mathrm{P} 1$ & - & - & Vibrio sp. \\
\hline 83 & Dez/05 & P2 & - & - & Vibrio sp. \\
\hline 263 & Nov/06 & P2 & - & - & Alteromonas sp. \\
\hline 101 & Jan/06 & P1 & - & - & Vibrio sp. \\
\hline 271 & Jan/07 & $\mathrm{P} 2$ & - & - & Vibrio sp. \\
\hline 27 & Set/05 & $\mathrm{P} 2$ & - & - & Vibrio sp. \\
\hline 92 & Jan/06 & $\mathrm{P} 1$ & - & - & Vibrio sp. \\
\hline 103 & Jan/06 & $\mathrm{P} 1$ & - & - & Vibrio sp. \\
\hline 163 & Abr/06 & $\mathrm{P} 1$ & - & - & Vibrio sp. \\
\hline 3 & Ago/05 & $\mathrm{P} 1$ & - & - & Vibrio sp. \\
\hline 259 & Nov/06 & P2 & - & - & Photobacterium sp. \\
\hline 30 & Out/05 & $\mathrm{P} 1$ & - & - & Vibrio sp. \\
\hline 148 & Mar/06 & $\mathrm{P} 2$ & - & - & Vibrio sp. \\
\hline 6 & Ago/05 & $\mathrm{P} 1$ & - & - & Vibrio sp. \\
\hline 220 & Ago/06 & $\mathrm{P} 1$ & - & - & Vibrio sp. \\
\hline 7 & Ago/05 & P2 & - & - & Alcaligenes sp. \\
\hline 126 & $\mathrm{Fev} / 06$ & $\mathrm{P} 1$ & - & + & Yangia sp. \\
\hline
\end{tabular}

Figura 23 - Dendrograma construído pelo programa BioNumerics para a técnica de BOX-PCR, usando o coeficiente de Dice, com as bactérias marinhas identificadas pelo seqüenciamento parcial da região $16 \mathrm{~S}$ rRNA.

(continua) 

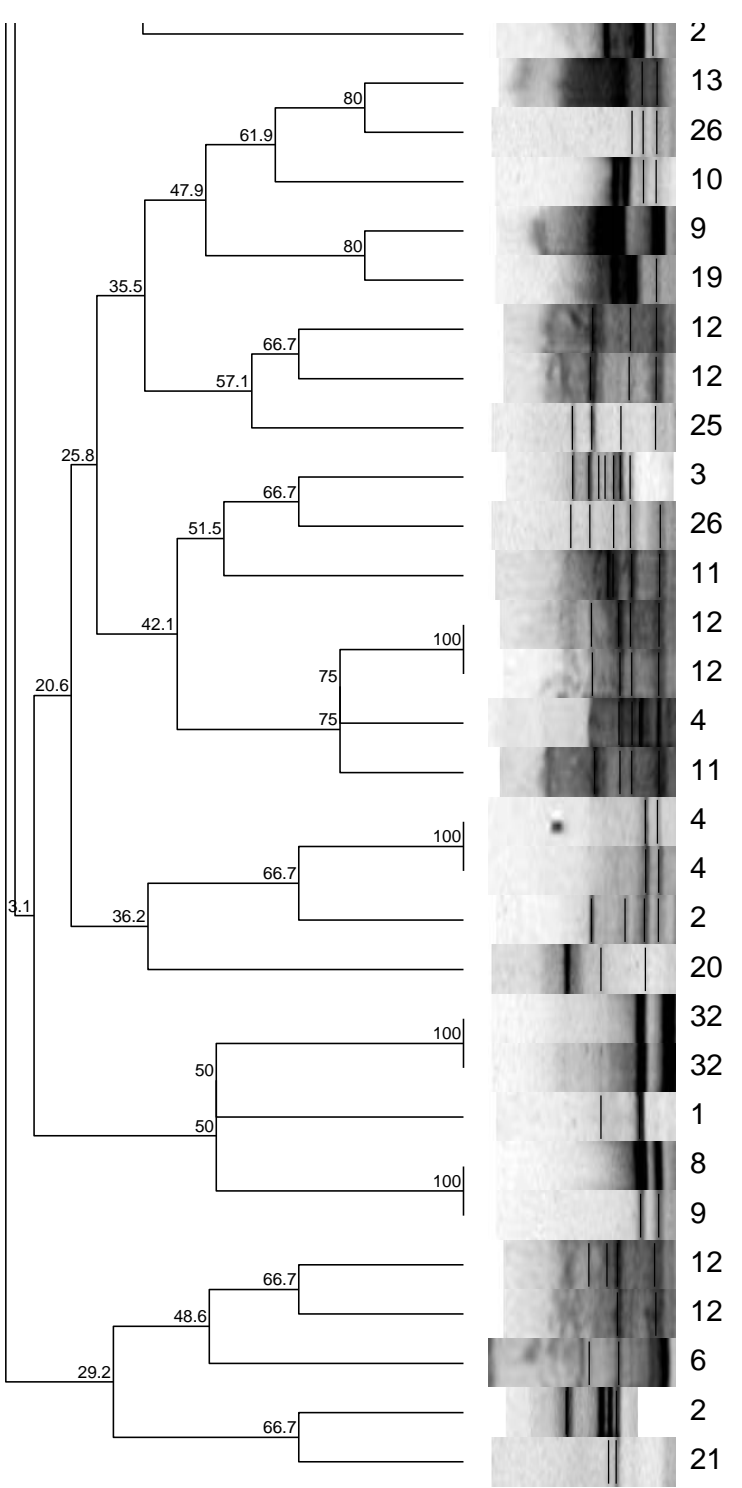

\begin{tabular}{llllll} 
I & Ago/U5 & P2 & - & - & Alcalıgenes sp. \\
126 & Fev/06 & P1 & - & + & Yangia sp. \\
224 & Ago/06 & P2 & - & - & Vibrio sp. \\
85 & Dez/05 & P2 & - & - & Vibrio sp. \\
76 & Dez/05 & P1 & + & - & Vibrio sp. \\
174 & Mai/06 & P1 & - & - & Vibrio sp. \\
105 & Jan/06 & P2 & - & - & Vibrio sp. \\
108 & Jan/06 & P2 & - & - & Vibrio sp. \\
219 & Ago/06 & P1 & - & - & Vibrio sp. \\
17 & Set/05 & P1 & - & - & Vibrio sp. \\
223 & Ago/06 & P2 & - & - & Vibrio sp. \\
91 & Jan/06 & P1 & - & - & Vibrio sp. \\
104 & Jan/06 & P2 & - & - & Vibrio sp. \\
109 & Jan/06 & P2 & - & - & Vibrio sp. \\
25 & Set/05 & P2 & - & - & Aeromonas sp. \\
102 & Jan/06 & P1 & - & - & Vibrio sp. \\
23 & Set/05 & P2 & - & - & Vibrio sp. \\
26 & Set/05 & P2 & - & - & Vibrio sp. \\
10 & Ago/05 & P2 & - & - & Vibrio sp. \\
181 & Mai/06 & P2 & - & - & Vibrio sp. \\
257 & Nov/06 & P2 & - & - & Pseudomonas sp. \\
258 & Nov/06 & P2 & - & - & Pseudomonas sp. \\
4 & Ago/05 & P1 & - & - & Vibrio sp. \\
71 & Nov/05 & P2 & - & - & Thalassobius sp. \\
78 & Dez/05 & P1 & - & - & Vibrio sp. \\
106 & Jan/06 & P2 & - & - & Vibrio sp. \\
107 & Jan/06 & P2 & - & - & Vibrio sp. \\
56 & Out/05 & P2 & - & - & Vibrio sp. \\
136 & Ago/05 & P2 & - & - & Jibrio sp. \\
& Jun/06 & P1 & - & - & Vibrio sp. \\
\hline 10 & & & &
\end{tabular}

Figura 23 - Dendrograma construído pelo programa BioNumerics para a técnica de BOX-PCR, usando o coeficiente de Dice, com as bactérias marinhas identificadas pelo seqüenciamento parcial da região $16 \mathrm{~S}$ rRNA.

Da mesma maneira, para a análise do ERIC-PCR, os isolados que amplificaram apenas 1 banda ou que não apresentaram produtos de amplificação foram excluídos e, o dendrograma obtido, agora com os resultados do seqüenciamento, mostra os agrupamentos de $54,8 \%$ ( $\mathrm{n}=$ 91) dos isolados que tiveram seus gêneros identificados (Figura 24).

Analisando o dendrograma gerado pela técnica de ERIC-PCR foi possível observar que a similaridade existente entre os 91 isolados de bactérias marinhas também foi de 7,4\%. Foram identificados basicamente 8 clusters com similaridade maior que $70 \%$, onde 3 
apresentaram $100 \%$ de similaridade. Além desses 3, pôde-se observar mais 5 subclusters com $100 \%$ de similaridade, os quais foram formados pelo agrupamento de 2 a 6 isolados cada.

Os isolados que se agruparam nos clusters e subclusters com $100 \%$ de similaridade foram identificados como pertencentes aos gêneros Vibrio e Pseudomonas, levando-se em consideração o seqüenciamento parcial do gene $16 \mathrm{~S}$ rDNA, representando $87,5 \%(\mathrm{n}=7)$ e $12,5 \%(\mathrm{n}=1)$ desses clusters, respectivamente.

Dos 11 gêneros identificados pelo seqüenciamento, dois (Pseudoalteromonas sp. e Paracoccus sp.) não amplificaram com a técnica de ERIC-PCR o que corresponde a apenas dois isolados, um de cada gênero. Assim como aconteceu com os isolados agrupados no dendrograma gerado pela técnica de BOX-PCR, os isolados que foram identificados como sendo do mesmo gênero também não se agruparam, com exceção dos isolados do gênero Vibrio. Assim, a técnica de ERIC-PCR também não foi útil para agrupar os isolados com características semelhantes. 


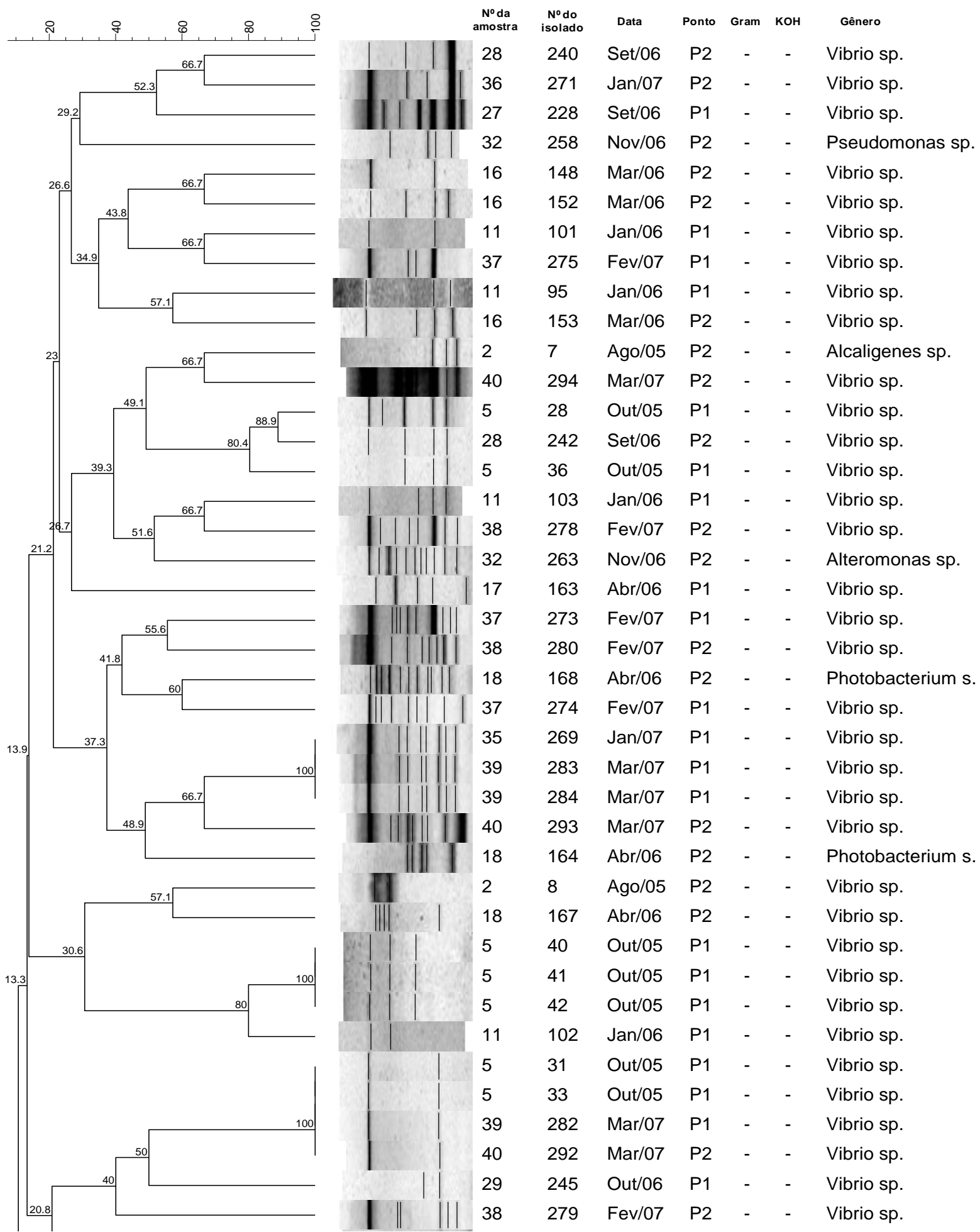

Figura 24 - Dendrograma construído pelo programa BioNumerics para a técnica de ERIC-PCR, usando o coeficiente de Dice, com as bactérias marinhas identificadas pelo seqüenciamento parcial da região $16 \mathrm{~S}$ rRNA. 


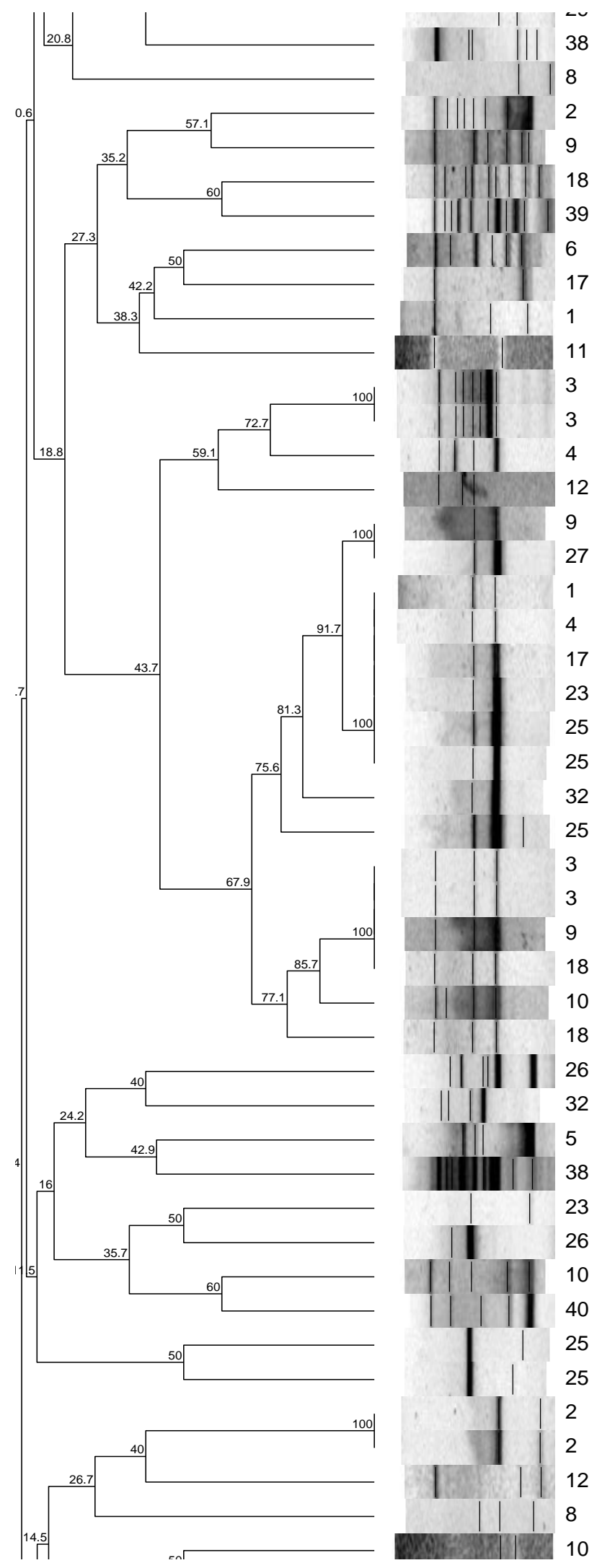

\begin{tabular}{|c|c|c|c|c|c|}
\hline-.2 & ユ ֻu & & & & anu ur. \\
\hline 279 & Fev/07 & P2 & - & - & Vibrio sp. \\
\hline 71 & Nov/05 & P2 & - & - & Thalassobius sp. \\
\hline 13 & Ago/05 & P2 & & - & Vibrio sp. \\
\hline 80 & Dez/05 & $\mathrm{P} 1$ & - & - & Vibrio sp. \\
\hline 171 & Abr/06 & P2 & - & - & Shewanella sp. \\
\hline 289 & Mar/07 & $\mathrm{P} 1$ & - & - & Vibrio sp. \\
\hline 45 & Out/05 & P2 & & - & Vibrio sp. \\
\hline 157 & Abr/06 & $\mathrm{P} 1$ & - & - & Vibrio sp. \\
\hline 3 & Ago/05 & P1 & - & - & Vibrio sp. \\
\hline 91 & Jan/06 & P1 & - & - & Vibrio sp. \\
\hline 21 & Set/05 & P1 & - & - & Vibrio sp. \\
\hline 22 & Set/05 & P1 & - & - & Vibrio sp. \\
\hline 26 & Set/05 & P2 & - & - & Vibrio sp. \\
\hline 115 & Jan/06 & P2 & - & - & Vibrio sp. \\
\hline 77 & Dez/05 & P1 & - & - & Vibrio sp. \\
\hline 231 & Set/06 & P1 & - & - & Vibrio sp. \\
\hline 1 & Ago/05 & $\mathrm{P} 1$ & - & - & Vibrio sp. \\
\hline 23 & Set/05 & P2 & - & - & Vibrio sp. \\
\hline 162 & Abr/06 & $\mathrm{P} 1$ & - & - & Vibrio sp. \\
\hline 203 & Jul/06 & P1 & - & - & Vibrio sp. \\
\hline 214 & Ago/06 & $\mathrm{P} 1$ & - & - & Vibrio sp. \\
\hline 218 & Ago/06 & P1 & - & - & Vibrio sp. \\
\hline 260 & Nov/06 & P2 & - & - & Vibrio sp. \\
\hline 217 & Ago/06 & P1 & - & - & Vibrio sp. \\
\hline 17 & Set/05 & P1 & - & - & Vibrio sp. \\
\hline 18 & Set/05 & P1 & - & - & Vibrio sp. \\
\hline 76 & Dez/05 & P1 & + & - & Vibrio sp. \\
\hline 170 & Abr/06 & P2 & - & - & Vibrio sp. \\
\hline 85 & Dez/05 & P2 & - & - & Vibrio sp. \\
\hline 169 & Abr/06 & P2 & - & - & Vibrio sp. \\
\hline 225 & Ago/06 & P2 & - & - & Vibrio sp. \\
\hline 259 & Nov/06 & P2 & - & - & Photobacterium s \\
\hline 30 & Out/05 & $\mathrm{P} 1$ & - & - & Vibrio sp. \\
\hline 277 & Fev/07 & P2 & - & - & Vibrio sp. \\
\hline 202 & Jul/06 & P1 & - & - & Vibrio sp. \\
\hline 224 & Ago/06 & P2 & - & - & Vibrio sp. \\
\hline 83 & Dez/05 & P2 & - & - & Vibrio sp. \\
\hline 291 & Mar/07 & P2 & - & - & Vibrio sp. \\
\hline 216 & Ago/06 & P1 & - & - & Vibrio sp. \\
\hline 220 & Ago/06 & P1 & - & - & Vibrio sp. \\
\hline 14 & Ago/05 & P2 & - & - & Pseudomonas sp \\
\hline 15 & Ago/05 & P2 & - & - & Pseudomonas $\mathrm{sp}$ \\
\hline 105 & Jan/06 & P2 & - & - & Vibrio sp. \\
\hline 74 & Nov/05 & P2 & - & + & Yangia sp. \\
\hline 87 & Dez/05 & P2 & - & - & Vibrio sp. \\
\hline
\end{tabular}

Figura 24 - Dendrograma construído pelo programa BioNumerics para a técnica de ERIC-PCR, usando o coeficiente de Dice, com as bactérias marinhas identificadas pelo seqüenciamento parcial da região $16 \mathrm{~S}$ rRNA.

(continua) 

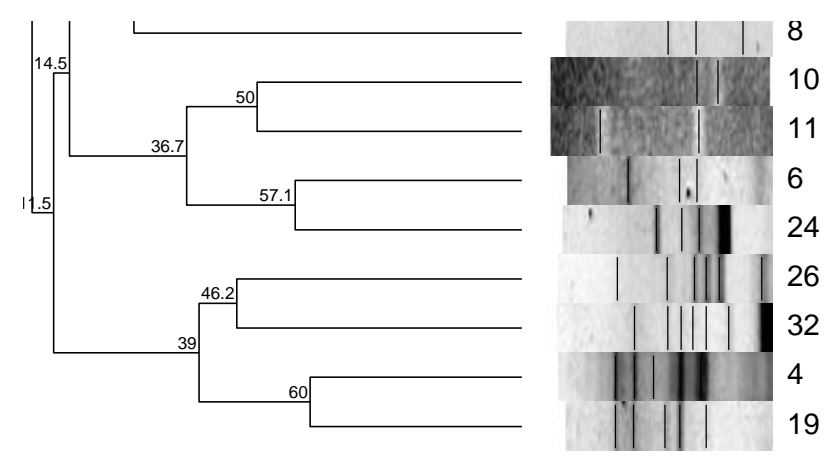

$\begin{array}{llllll}74 & \text { Nov/05 } & \text { P2 } & - & + & \text { Yangia sp. } \\ 87 & \text { Dez/05 } & \text { P2 } & - & - & \text { Vibrio sp. } \\ 96 & \text { Jan/06 } & \text { P1 } & - & - & \text { Vibrio sp. } \\ 46 & \text { Out/05 } & \text { P2 } & - & - & \text { Vibrio sp. } \\ 209 & \text { Jul/06 } & \text { P2 } & - & - & \text { Vibrio sp. } \\ 223 & \text { Ago/06 } & \text { P2 } & - & - & \text { Vibrio sp. } \\ 265 & \text { Nov/06 } & \text { P2 } & - & - & \text { Vibrio sp. } \\ 25 & \text { Set/05 } & \text { P2 } & - & - & \text { Aeromonas sp. } \\ 174 & \text { Mai/06 } & \text { P1 } & - & - & \text { Vibrio sp. }\end{array}$

Figura 24 - Dendrograma construído pelo programa BioNumerics para a técnica de ERIC-PCR, usando o coeficiente de Dice, com as bactérias marinhas identificadas pelo seqüenciamento parcial da região $16 \mathrm{~S}$ rRNA.

\subsection{DETERMINAÇÃO DA CONCENTRAÇÃO BACTERIANA PELA TÉCNICA DE HIBRIDIZAÇÃO in situ FLUORESCENTE (FISH)}

A técnica de hibridização fluorescente foi aplicada nas 40 amostras de água do mar para quantificar as bactérias pertencentes aos grupos Alpha-, Beta-, Gamma- e DeltaProteobacteria, além de quantificar as células totais através da coloração com DAPI.

Conforme é possível observar nos resultados mostrados na figura 25, a quantificação dos quatro grupos de proteobactérias, no ponto 1 , teve uma variação de $2,1 \times 10^{5}$ a $2,8 \times 10^{6}$ cél/mL para alpha-proteobacteria, 4,7 x $10^{5}$ a 3,6 × $10^{6}$ cél/mL para beta-proteobacteria, 1,0 x $10^{5}$ a $2,6 \times 10^{6}$ cél $/ \mathrm{mL}$ para gamma-proteobacteria e $3,2 \times 10^{5}$ a $2,9 \times 10^{6}$ cél $/ \mathrm{mL}$ para delta-proteobacteria, enquanto que a quantificação de células totais feita através da coloração com DAPI foi de $6,3 \times 10^{6}$ a $2,5 \times 10^{7}$ cél $/ \mathrm{mL}$.

Seguindo estas mesmas tendências, nos resultados do ponto 2 foi possível verificar que a contagem direta feita através da coloração com DAPI obteve uma variação de $6,8 \times 10^{6}$ a 2,3 x $10^{7}$ cél $/ \mathrm{mL}$, encontrando-se, também, valores muito próximos aos verificados no ponto 1 para os grupos proteobacterianos: $2,4 \times 10^{5}$ a $2,7 \times 10^{6}$ cél/mL para alpha-proteobacteria, $5,0 \times 10^{5}$ a $7,0 \times 10^{6}$ cél $/ \mathrm{mL}$ para beta-proteobacteria, $4,2 \times 10^{4}$ a $1,8 \times 10^{6}$ cél $/ \mathrm{mL}$ para gamma-proteobacteria e $1,2 \times 10^{5}$ a 1,6 × $10^{6}$ cél/mL para delta-proteobacteria (Figura 26). 


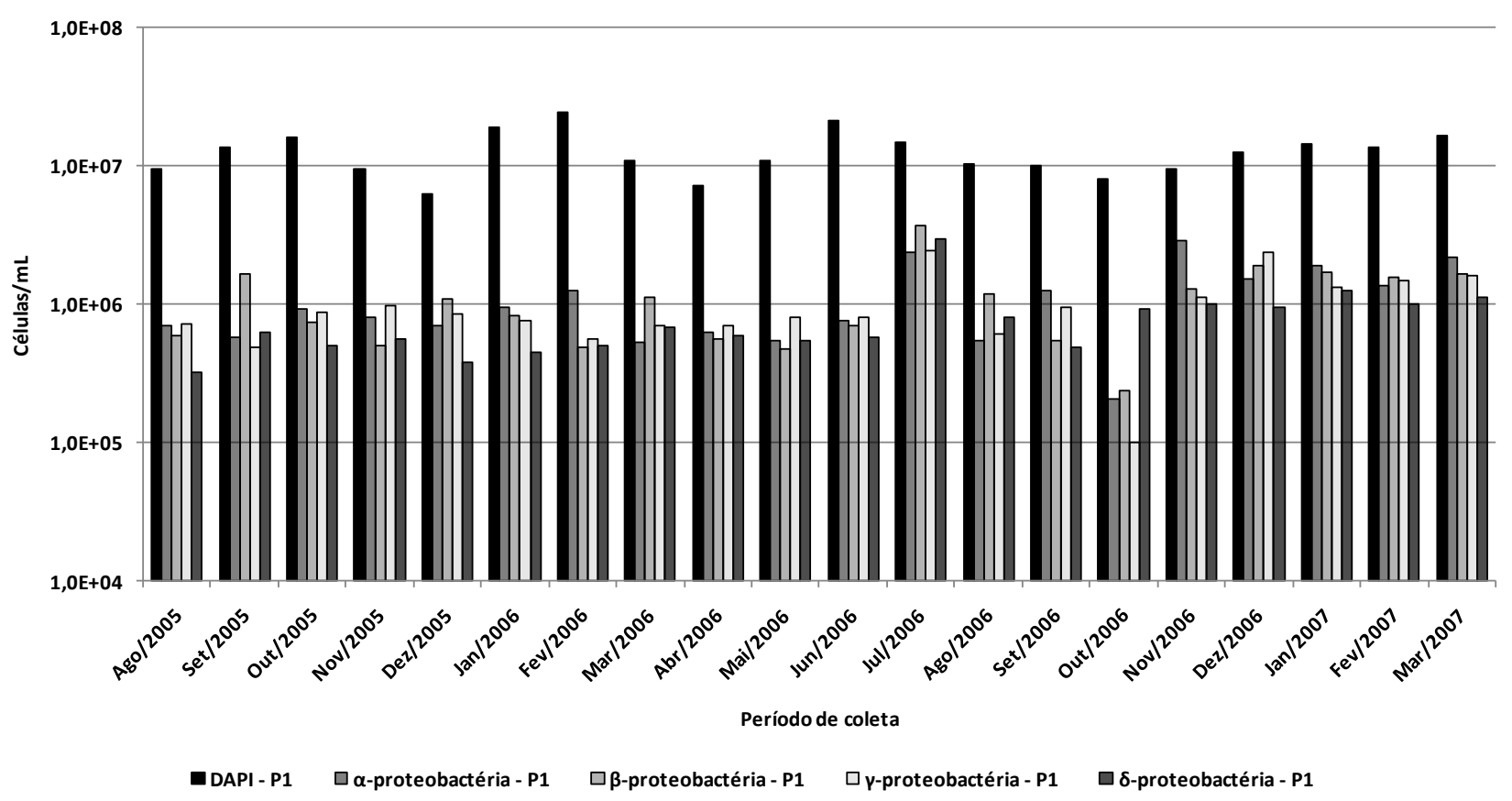

Figura 25 - Variação da concentração de células bacterianas totais (DAPI) e dos grupos bacterianos $\alpha$-, $\beta$-, $\gamma$ - e $\delta$-proteobacteria nas amostras de água do mar coletadas no ponto 1 no Canal de São Sebastião.

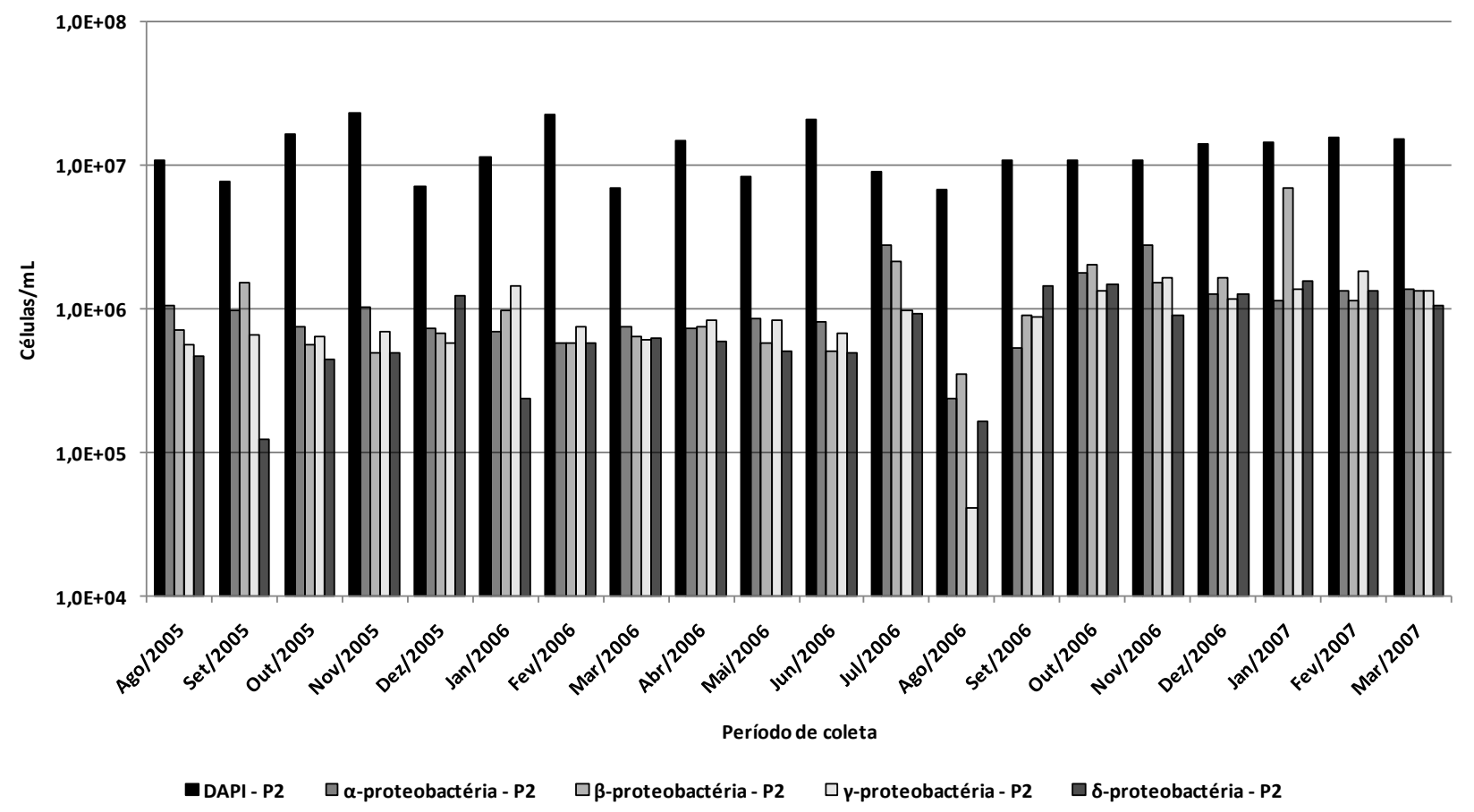

Figura 26 - Variação da concentração de células bacterianas totais (DAPI) e dos grupos bacterianos $\alpha$-, $\beta$-, $\gamma$ - e $\delta$-proteobacteria nas amostras de água do mar coletadas no ponto 2 no Canal de São Sebastião. 
Visualmente, nas contagens bacterianas foram observadas variações na mesma ordem de magnitude para ambos os pontos. Concomitantemente, análises estatísticas foram feitas para verificar esses resultados utilizando o Teste de Mann-Whitney. Este teste estatístico mostrou que o valor de significância calculada (p) para a contagem direta total (DAPI) foi $\mathrm{p}=$ 0,871. Em se tratando dos quatro grupos proteobacterianos o mesmo resultado foi verificado, ou seja, todos os valores de significância calculada (p) estavam acima do valor de $\alpha: p=0,756$ $(\alpha$-proteobacteria $), \mathrm{p}=0,871(\beta$-proteobacteria $), \mathrm{p}=0,839(\gamma$-proteobacteria $)$ e $\mathrm{p}=0,914(\delta$ proteobacteria).

Embora, no ponto 2, o mês de agosto/2006 tenha apresentado uma queda no valor de $\gamma$-proteobacteria em relação aos outros meses, essa diferença não foi suficiente para diferenciar um ponto do outro. Portanto, podemos inferir que, em relação às contagens dos quatro grupos de bactérias e de células totais, ambos os pontos são estatisticamente semelhantes. Isso pode ser verificado também nas análises de mediana e percentil 25 e 75 abaixo (Figura 27). 

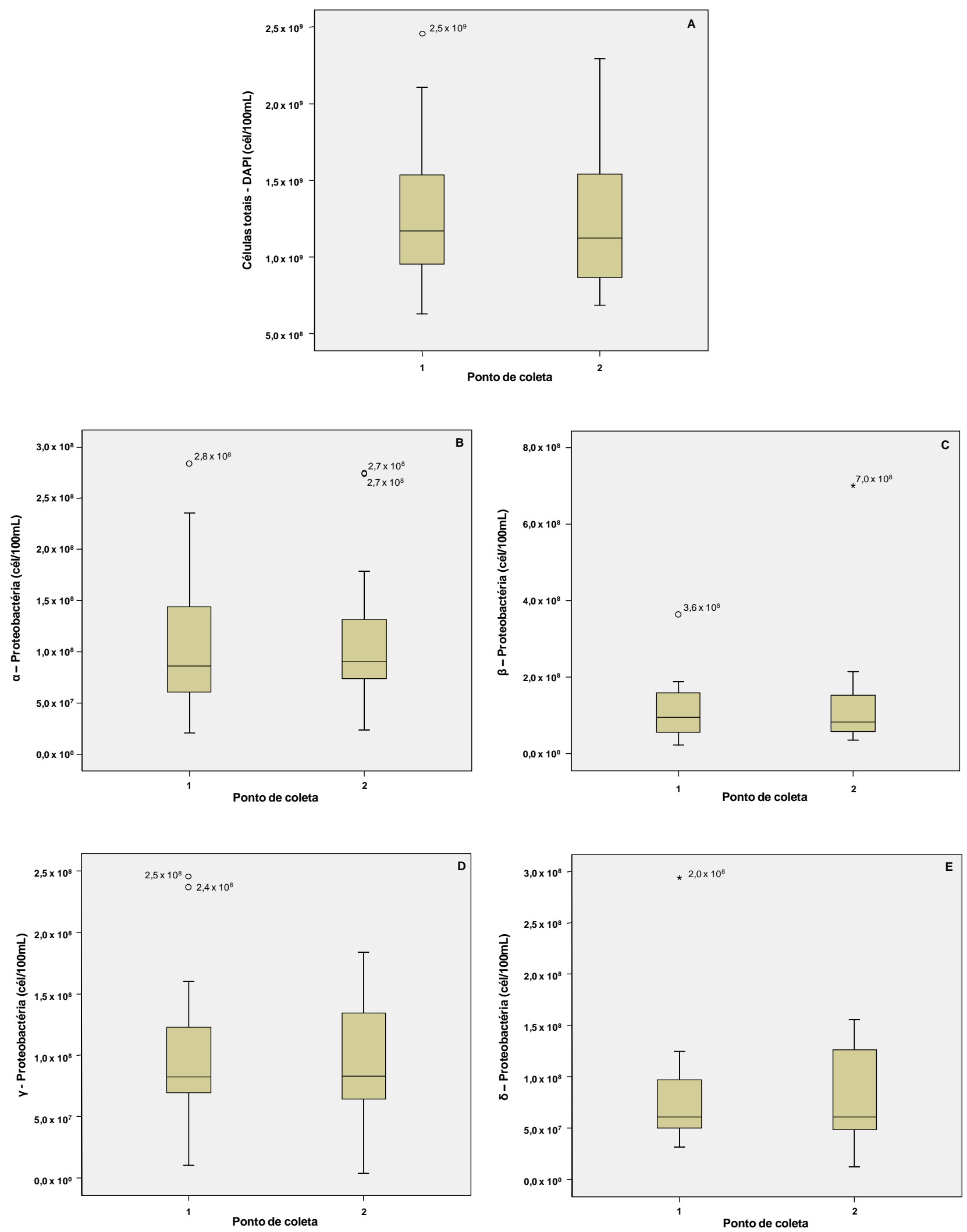

Figura 27 - Boxplot mostrando os valores da mediana e percentis 25 e 75 das concentrações de células totais e dos grupos bacterianos $\alpha$-, $\beta$-, $\gamma$ - e $\delta$ - proteobacteria por ponto de coleta. Nota: Para efeito de visualização, as concentrações bacterianas estão apresentadas em células/100 mL. 
Como foi inferido que ambos os pontos são estatisticamente semelhantes pelas concentrações de células totais e dos quatro grupos bacterianos, uma análise mais detalhada foi feita para comparar os resultados obtidos entre os grupos $\alpha$-, $\beta$-, $\gamma$ - e $\delta$-proteobacteria em relação às células totais. Para isso foi feita a média das contagens mensais obtidas nos dois pontos, uma vez que já foi constatado que não houve diferença nas mesmas.

Ao longo dos 20 meses de amostragem, os dados nos mostraram que nos meses de julho/2006, novembro/2006 e janeiro/2007, mais de 60\% das células totais foi composta por representantes dos quatro grupos de proteobactérias estudados, seguidos dos meses de dezembro/2005 e 2006 que apresentaram em torno de 46\% da população total. Apesar de oito meses (agosto, setembro, outubro, novembro, dezembro, janeiro, fevereiro e março) terem sido avaliados duas vezes em anos consecutivos ao longo do período estudado, somente quatro (agosto, setembro, dezembro e março) mantiveram constante a concentração bacteriana de $\alpha$-, $\beta$-, $\gamma$ - e $\delta$-proteobacteria em relação às células totais (Figura 28).

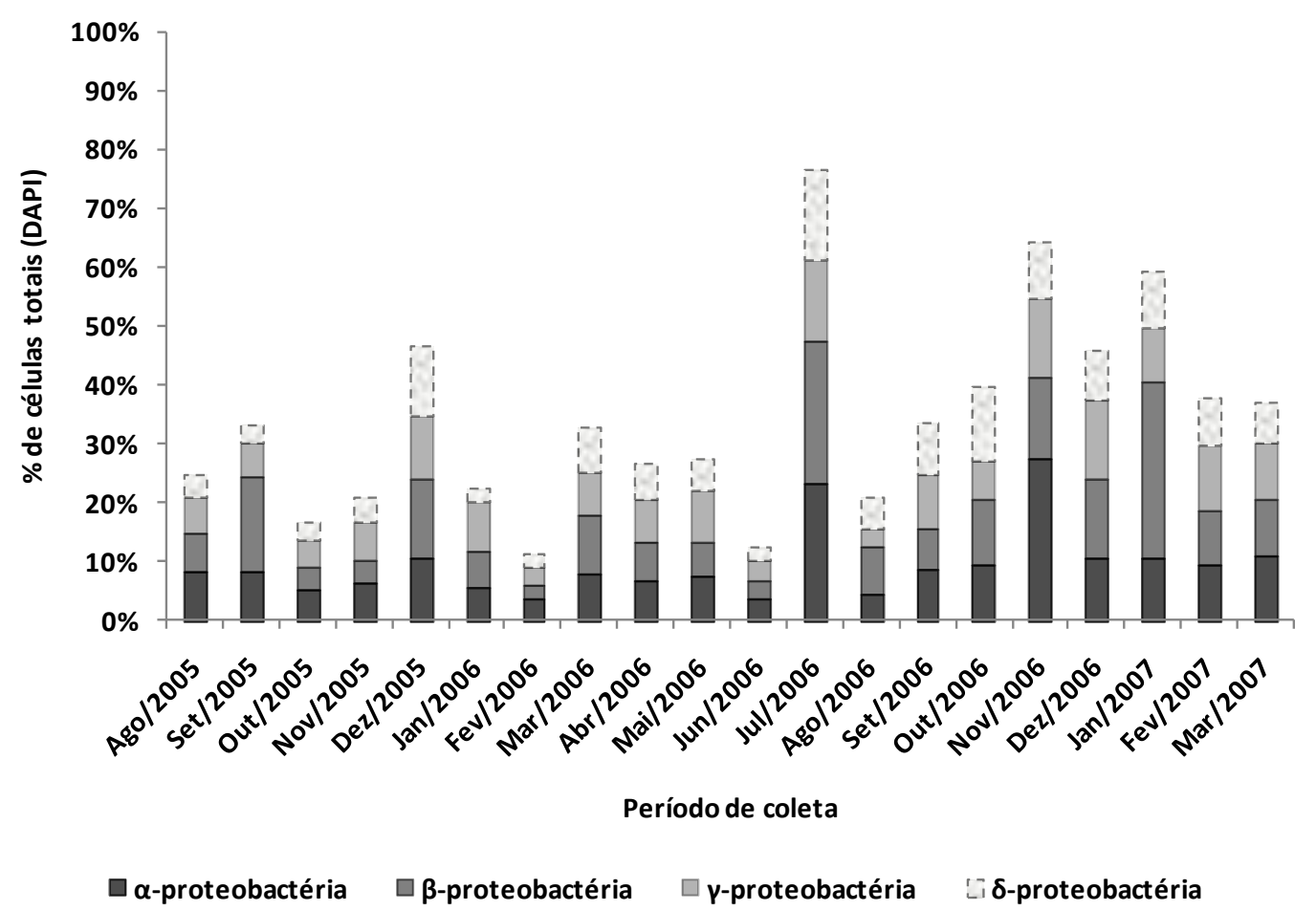

Figura 28 - Freqüência de células hibridizadas com as sondas fluorescentes para os grupos $\alpha$-, $\beta$-, $\gamma$ - e $\delta$ - proteobacteria, em relação ao total de células coradas com DAPI ao longo dos 20 meses de amostragem.

Nota: As porcentagens mostradas equivalem à média dos pontos 1 e 2 . 
Quando a composição da comunidade foi analisada, de acordo com o conjunto de sondas aqui utilizado, embora tenham sido constatados três picos com valores altos, dois no mês de julho/2006, sendo um nos valores de $\alpha$-proteobacteria $\left(2,5 \times 10^{6}\right.$ céls $\left./ \mathrm{mL}\right)$ e outro nos valores de $\beta$-proteobacteria $\left(2,9 \times 10^{6}\right.$ céls $\left./ \mathrm{mL}\right)$ e o outro pico em novembro/2006 também nos valores detectados com a sonda ALF1b $\left(2,8 \times 10^{8}\right.$ céls $\left./ \mathrm{mL}\right)$, verificou-se que a maior prevalência foi com a sonda BET42a apresentando 10,2\% das células totais (valor médio de todos os meses), seguida das células bacterianas hibridizadas com as sondas $\alpha$-proteobacteria, $\gamma$-proteobacteria e $\delta$-proteobacteria, respectivamente (Figura 29 e Tabela 4).

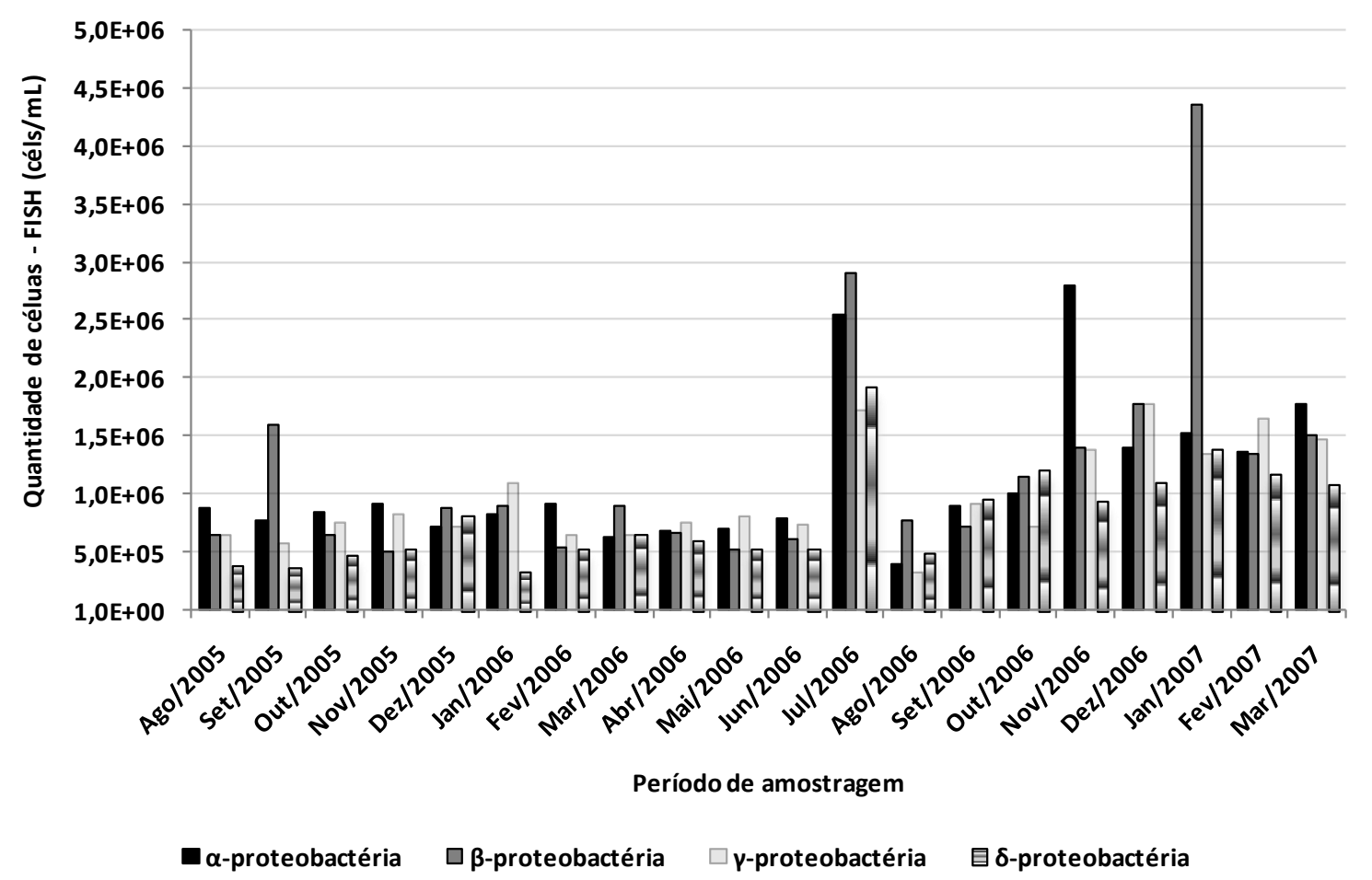

Figura 29 - Concentração de células hibridizadas com as sondas fluorescentes para os grupos $\alpha$-, $\beta$-, $\gamma$ - e $\delta$ - proteobacteria ao longo dos 20 meses de amostragem.

Nota: Os valores de contagens mostrados equivalem à média dos pontos 1 e 2 .

Conforme já mencionado, os meses de julho/2006, novembro/2006 e janeiro/2007 foram os que apresentaram maior porcentagem de células hibridizadas em comparação com o número de células totais: $76,6 \%, 64,3 \%$ e 59,4\%, respectivamente. Nesses meses, a maior concentração foi de $\beta$-proteobacteria em julho/2006 (24,4\%) e janeiro/2007 (30\%) e $\alpha$ proteobacteria em novembro/2006 (27,7\%). Por outro lado, os meses que apresentaram o menor número de células hibridizadas foram fevereiro/2006 (11,3\%) e junho/2006 (12,7\%) (Tabela 4). 
Tabela 4 - Percentual de $\alpha$-, $\beta$-, $\gamma$ - e $\delta$ - proteobacteria detectadas pela técnica de FISH em comparação às células totais detectadas por DAPI em amostras de água do mar coletadas no Canal de São Sebastião.

\begin{tabular}{|c|c|c|c|c|c|c|c|c|c|c|c|c|c|c|c|}
\hline \multirow{3}{*}{$\begin{array}{c}\begin{array}{c}\text { Período de } \\
\text { coleta }\end{array} \\
\text { Ago/2005 }\end{array}$} & \multirow{2}{*}{\multicolumn{3}{|c|}{$\begin{array}{l}\text { Células Totais - } \\
\text { DAPI }\left(10^{7} / \mathrm{mL}\right) \\
(M \pm D P)^{*}\end{array}$}} & \multicolumn{12}{|c|}{ Fração (\%) de células totais detectadas com as sondas (M $\pm \mathrm{DP})$ ** } \\
\hline & & & & \multicolumn{3}{|c|}{ ALF1b } & \multicolumn{3}{|c|}{ BET42a } & \multicolumn{3}{|c|}{ GAM42a } & \multicolumn{3}{|c|}{ DELTA } \\
\hline & 1,0 & \pm & 0,10 & 8,5 & \pm & 1,7 & 6,3 & \pm & 0,3 & 6,3 & \pm & 1,6 & 3,8 & \pm & 0,7 \\
\hline Set/2005 & 1,0 & \pm & 0,42 & 8,4 & \pm & 5,8 & 16,0 & \pm & 5,6 & 6,0 & \pm & 3,4 & 3,1 & \pm & 2,1 \\
\hline Out/2005 & 1,6 & \pm & 0,04 & 5,2 & \pm & 0,9 & 4,0 & \pm & 0,8 & 4,6 & \pm & 1,1 & 2,9 & \pm & 0,3 \\
\hline Nov/2005 & 1,6 & \pm & 0,95 & 6,5 & \pm & 2,8 & 3,7 & \pm & 2,2 & 6,6 & \pm & 5,1 & 4,1 & \pm & 2,6 \\
\hline Dez/2005 & 0,7 & \pm & 0,06 & 10,7 & \pm & 0,4 & 13,4 & \pm & 5,5 & 10,8 & \pm & 3,6 & 11,8 & \pm & 8,3 \\
\hline Jan/2006 & 1,5 & \pm & 0,51 & 5,5 & \pm & 0,6 & 6,5 & \pm & 2,9 & 8,2 & \pm & 6,0 & 2,2 & \pm & 0,2 \\
\hline Fev/2006 & 2,3 & \pm & 0,17 & 3,9 & \pm & 1,8 & 2,3 & \pm & 0,4 & 2,8 & \pm & 0,7 & 2,3 & \pm & 0,4 \\
\hline Mar/2006 & 0,9 & \pm & 0,27 & 7,8 & \pm & 4,1 & 9,9 & \pm & 0,9 & 7,6 & \pm & 1,6 & 7,7 & \pm & 1,9 \\
\hline Abr/2006 & 1,1 & \pm & 0,54 & 6,8 & \pm & 2,7 & 6,4 & \pm & 1,9 & 7,5 & \pm & 2,8 & 6,1 & \pm & 3,0 \\
\hline Mai/2006 & 1,0 & \pm & 0,18 & 7,7 & \pm & 3,6 & 5,7 & \pm & 1,8 & 8,7 & \pm & 1,9 & 5,6 & \pm & 0,7 \\
\hline Jun/2006 & 2,1 & \pm & 0,01 & 3,7 & \pm & 0,2 & 2,9 & \pm & 0,6 & 3,5 & \pm & 0,4 & 2,5 & \pm & 0,3 \\
\hline Jul/2006 & 1,2 & \pm & 0,40 & 23,2 & \pm & 10,1 & 24,4 & \pm & 0,8 & 13,8 & \pm & 4,2 & 15,2 & \pm & 6,9 \\
\hline Ago/2006 & 0,9 & \pm & 0,25 & 4,4 & \pm & 1,3 & 8,2 & \pm & 4,4 & 3,2 & \pm & 3,7 & 5,1 & \pm & 3,8 \\
\hline Set/2006 & 1,1 & \pm & 0,0 & 8,8 & \pm & 5,6 & 6,9 & \pm & 2,0 & 8,9 & \pm & 1,1 & 9,1 & \pm & 5,8 \\
\hline Out/2006 & 1,1 & \pm & 0,0 & 9,5 & \pm & 9,8 & 10,9 & \pm & 11,2 & 6,8 & \pm & 7,8 & 12,7 & \pm & 1,4 \\
\hline Nov/2006 & 1,1 & \pm & 0,0 & 27,7 & \pm & 3,3 & 13,7 & \pm & 0,4 & 13,6 & \pm & 2,3 & 9,4 & \pm & 1,5 \\
\hline Dez/2006 & 1,4 & \pm & 0,0 & 10,6 & \pm & 2,1 & 13,4 & \pm & 2,2 & 13,6 & \pm & 7,3 & 8,3 & \pm & 1,1 \\
\hline Jan/2007 & 1,5 & \pm & 0,0 & 10,5 & \pm & 3,8 & 30,0 & \pm & 25,8 & 9,3 & \pm & 0,1 & 9,7 & \pm & 1,4 \\
\hline Fev/2007 & 1,6 & \pm & 0,0 & 9,3 & \pm & 1,0 & 9,3 & \pm & 3,0 & 11,3 & \pm & 0,6 & 8,0 & \pm & 0,8 \\
\hline Mar/2007 & 1,5 & \pm & 0,0 & 11,2 & \pm & 3,1 & 9,5 & \pm & 0,9 & 9,4 & \pm & 0,6 & 6,9 & \pm & 0,0 \\
\hline
\end{tabular}

*(M $\pm \mathrm{DP})$ : média e desvio padrão dos valores de contagens obtidos nos dois pontos de coleta. **(M $\pm \mathrm{DP})$ : média e desvio padrão das porcentagens de sondas detectadas em relação ao DAPI nos dois pontos de coleta.

O teste de correlação Spearman também foi aplicado nestas análises e verificou-se que houve uma fraca correlação negativa entre as contagens dos grupos proteobacterianos e a condutividade ( $\alpha$-proteobacteria: $\mathrm{p}=0,003$ e $\mathrm{r}=-0,459 ; \beta$-proteobacteria: $\mathrm{p}=0,029$ e $\mathrm{r}=-$ 0,346; $\gamma$-proteobacteria: $\mathrm{p}=0,002$ e $\mathrm{r}=-0,483 ; \delta$ - proteobacteria: $\mathrm{p}=0,000$ e $\mathrm{r}=-0,593)$. Outra correlação, mas agora positiva, foi verificada entre $\delta$ - proteobacteria e $\mathrm{pH}(\mathrm{p}=0,012$ e $\mathrm{r}=0,393)$, assim como entre $\gamma$-proteobacteria e a temperatura máxima do dia $(\mathrm{p}=0,054$ e $\mathrm{r}=$ $0,307)$ e $\gamma$-proteobacteria e a temperatura da água do $\operatorname{mar}(\mathrm{p}=0,028$ e $\mathrm{r}=0,348)$.

O mesmo foi feito com o Teste de Mann-Whitney, o qual constatou que a única relação estatisticamente significativa foi observada quando a corrente marítima leste estava presente, fazendo que a concentração celular de $\delta$-proteobacteria aumentasse $(\mathrm{p}=0,032)$, quando 
levadas em consideração as condições climáticas (corrente marítima, direção do vento e condição do tempo).

Através da aplicação do teste estatístico de Friedman com Pós-teste de Müller-Dunn foi possível comparar, entre si, os resultados de contagens de células hibridizadas. A análise mostrou que houve diferença significava entre as células hibridizadas com as sondas para $\alpha$ proteobacteria e $\delta$-proteobacteria $(\mathrm{p}<0,001$ ), entre as células com as sondas para $\beta$ proteobacteria e $\delta$-proteobacteria $(\mathrm{p}<0,01)$, além das sondas para $\gamma$-proteobacteria e $\delta$ proteobacteria $(\mathrm{p}<0,05)$.

O inverso também ocorreu, ou seja, não houve diferença estatisticamente significante entre as contagens de células hibridizadas quando analisados os resultados das sondas para $\alpha$ proteobacteria com $\beta$-proteobacteria, $\alpha$-proteobacteria com $\gamma$-proteobacteria e $\beta$ proteobacteria com $\gamma$-proteobacteria, onde a significância calculada foi $\mathrm{p}>0,05$ para as três análises mencionadas. Os resultados de mediana e percentil 25 e 75 podem ser visualizados na figura 30 .

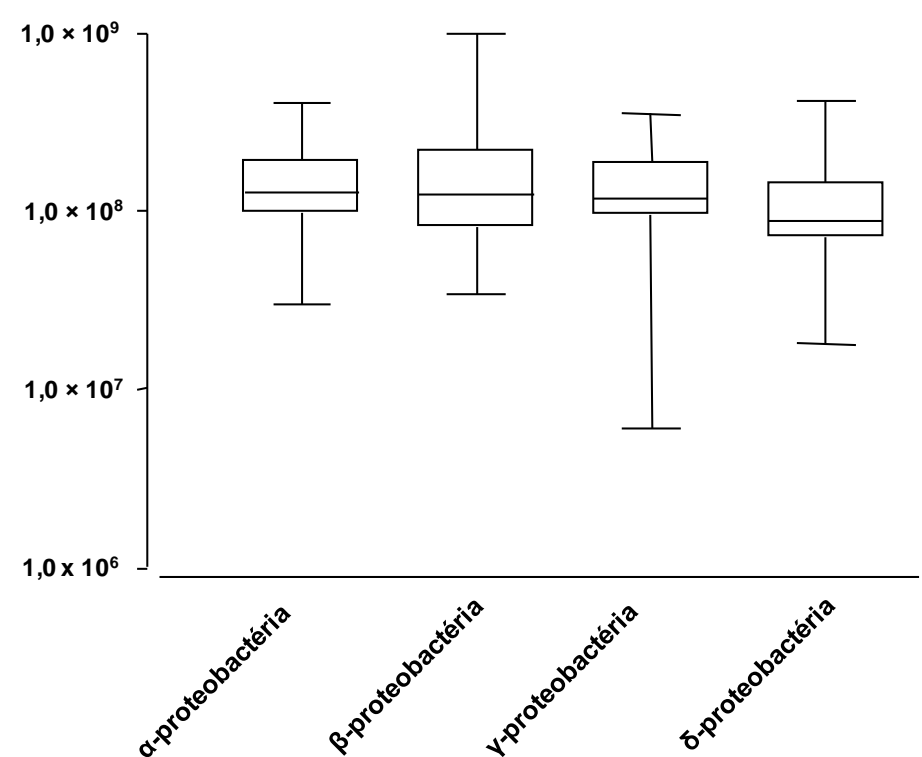

Figura 30 - Box-plot mostrando os valores de mediana e percentis 25 e 75 das contagens de células hibridizadas com as sondas fluorescentes para os grupos $\alpha$-, $\beta$-, $\gamma$-e $\delta$-proteobacteria ao longo dos 20 meses de amostragem.

Nota: Os valores de contagens mostrados equivalem à média dos pontos $1 \mathrm{e} 2$.

Diante disso, como ocorreu com as bactérias marinhas viáveis, pode-se considerar que os dois pontos são semelhantes no que se refere aos valores de contagens de células totais e dos grupos bacterianos. No entanto, as contagens desses quatro grupos da classe 
Proteobacteria foram diversas, a ponto de alguns grupos, como no caso das $\beta$-proteobacteria, se sobressaírem sobre outros ( $\delta$-proteobacteria).

Comparando os resultados das amostras hibridizadas com as quatro sondas para os grupos das proteobactérias e os resultados do seqüenciamento dos isolados de bactérias marinhas viáveis observou-se uma diferença notável, no que se refere à frequiência dos grupos proteobacterianos. Nas amostras hibridizadas, a maior porcentagem de células foi para a subclasse $\beta$-proteobacteria, enquanto que nas amostras de bactérias viáveis a maior porcentagem foi verificada para a subclasse $\gamma$-proteobacteria.

Deve-se lembrar que essas duas análises foram feitas utilizando metodologias diferentes, onde o resultado do seqüenciamento foi obtido de bactérias marinhas que foram cultiváveis, enquanto que o resultado das células bacterianas hibridizadas foi obtido de amostra total de água do mar.

\subsection{CARACTERIZAÇÃO MOLECULAR DAS POPULAÇÕES BACTERIANAS: CONSTRUÇÃO DE BIBLIOTECAS DO GENE 16S rDNA}

\subsubsection{Extração do DNA total das amostras de água do mar}

Foi realizada a extração de DNA total de 3 amostras de água do mar coletadas no Canal de São Sebastião. Dentre os 20 meses de coleta foram selecionados 3 (fevereiro/2006, novembro/2006, fevereiro/2007). A escolha pela extração de DNA desses 3 meses, especificamente, se deu pelo fato de, os meses de fevereiro/2006 e fevereiro/2007 equivalerem ao mesmo período, mas em anos diferentes e, o mês de novembro/2006 ter sido o período no qual foi verificado a maior diversidade de bactérias marinhas para fins de comparação.

As três amostras de DNA total tiveram suas regiões 16S rRNA amplificadas, onde para isso cada amostra foi amplificada em 4 réplicas utilizado-se os iniciadores $27 \mathrm{~F}$ e $1041 \mathrm{R}$ já descritos anteriormente no item 4.5.4.1.

Após verificação da qualidade e concentração, as quatro réplicas de cada uma das três amostras amplificadas foram transferidas para um único tudo de microcentrífuga e purificadas. Os produtos da purificação foram visualizados em gel de agarose e quantificados por dosagem espectrofotométrica para verificar se os mesmos se encontravam na concentração adequada para ser utilizado na reação de clonagem. 


\subsubsection{Clonagem dos fragmentos amplificados}

Para facilitar a interpretação, os clones de cada uma das três amostras foram identificados como clones da biblioteca 1 (B1 - novembro/2006), biblioteca 2 (B2 fevereiro/2006) e biblioteca 3 (B3 - fevereiro/2007).

Cada amostra purificada foi clonada utilizando o vetor $p$-GEM e um total de 180, 220 e 120 clones foram obtidos para as bibliotecas 1,2 e 3 , respectivamente.

Como o vetor utilizado no estudo possui o sistema $\beta$-galactosidase que é induzido pelo IPTG e sinalizado pelo indicador $\mathrm{X}-\mathrm{Gal}$, os clones que tiveram o fragmento ligado ao plasmídeo transformado apresentaram coloração branca e os clones que receberam o plasmídeo sem o fragmento ligado apresentaram coloração azul (indicando a expressão do gene lac Z)

Dessa maneira, os clones que tiveram seus fragmentos ligados ao vetor (colônias brancas) foram submetidos à amplificação com os iniciadores M13F e M13R para a confirmação da inserção do inserto nos clones. Foi verificado que, dos 520 clones (180 da biblioteca 1, 220 da biblioteca 2 e 120 da biblioteca 3), 92,8\% ( $\mathrm{n}=167), 86,4 \%(\mathrm{n}=190)$ e $90,8 \%(\mathrm{n}=109)$ receberam o inserto.

\subsubsection{Seqüenciamento dos clones de 16S rRNA}

Como o número de clones que receberam o inserto foi elevado $(\mathrm{n}=466)$, foram selecionados apenas 100 de cada biblioteca para serem submetidos ao seqüenciamento utilizando o iniciador interno do vetor (T7). Os cromatogramas resultantes de cada um dos seqüenciamentos foram analisados no programa BioEdit e, com isso verificou-se que 17 seqüências (4 da biblioteca 1, 7 da biblioteca 2 e 6 da biblioteca 3) apresentaram-se ruins, as quais foram excluídas das análises posteriores.

Pelo fato dos clones terem sido seqüenciados utilizando-se apenas o iniciador interno do vetor (T7), os mesmos podem ter sido inseridos no plasmídeo tanto no sentido forward (5', - 3') como no sentido reverse (3' - 5'). Por este motivo, as seqüências de clones obtidas no seqüenciamento foram divididas em dois grupos (forward e reverse) e analisadas separadamente. Estes grupos serão identificados nas próximas etapas do trabalho como seqüências forward das bibliotecas e seqüências reverse das bibliotecas. O número de clones 
obtidos, seqüenciados e o número de sequiências em cada grupo podem ser verificados na tabela 5 .

Tabela 5 - Relação do número de clones obtidos e seqüenciados em cada biblioteca.

\begin{tabular}{|c|c|c|c|c|c|c|c|}
\hline \multirow{2}{*}{ Biblioteca } & \multirow{2}{*}{ Mês* } & \multicolumn{6}{|c|}{ Clones } \\
\hline & & Obtidos & $\begin{array}{c}\text { Insertos } \\
\text { dectados** }\end{array}$ & $\begin{array}{l}\text { Insertos não } \\
\text { detectados** }\end{array}$ & Sequenciados $* * *$ & $\begin{array}{l}\text { Sequências } \\
\text { forward }\end{array}$ & $\begin{array}{l}\text { Sequências } \\
\text { reverse }\end{array}$ \\
\hline B1 & Nov/2006 & 180 & 167 & 13 & 100 & 75 & 21 \\
\hline B2 & Fev/2006 & 220 & 190 & 30 & 100 & 78 & 15 \\
\hline B3 & Fev/2007 & 120 & 109 & 11 & 100 & 56 & 38 \\
\hline
\end{tabular}

As 209 seqüências forward dos clones das três bibliotecas e as 74 seqüências reverse das três bibliotecas que tiveram sequiências de boa qualidade, após análise de seus cromatogramas, foram editadas, onde as extremidades com baixa qualidade foram removidas e alinhadas no programa BioEdit.

Após edição, as seqüências foram analisadas através do programa DOTUR para a definição das OTUs. O programa DOTUR define o número de OTUs observados para cada faixa de distância que pode ser usada para formar as OTUs, usando algoritmos de agrupamentos por complete-linkage (furthest neighbor), onde a seqüência só é adicionada ao grupo se ela tiver o mesmo cutoff que todos os membros componentes do grupo.

Uma análise preliminar foi feita para cada uma das bibliotecas, tanto para as seqüências forward como para as reverse, separadamente, para definir o número de OTUs encontradas em cada biblioteca, considerado o cutoff de $97 \%$ de similaridade $(0,03$ de diferença) para identificar seqüências de mesma espécie. A distribuição das seqüências em OTUs será considerada para que somente uma sequência de cada OTU seja selecionada para representar os outros clones que possam ser iguais. O número de seqüências de clones dentro de cada OTU não foi constante e o mesmo pode ser verificado na tabela 6. 
Tabela 6 - Número de OTUs observadas em cada biblioteca, a partir do cutoff $(0,03)$ de distâncias definidas pelo programa DOTUR.

\begin{tabular}{|c|c|c|c|c|c|c|c|c|c|c|c|c|c|c|c|c|c|c|c|c|c|c|c|c|c|c|c|c|c|c|c|c|}
\hline Bibliotecas & Cutoff * & $\begin{array}{c}\text { № de } \\
\text { sequências }\end{array}$ & $\begin{array}{l}\text { № de } \\
\text { OTUs }\end{array}$ & & & & & & & & & & & & № & de in & livíd & uos e & $\mathrm{m} \mathrm{ca}$ & da $O$ & TUs & & & & & & & & & & & \\
\hline B1 - forward & 0.03 & 75 & 28 & 24 & 15 & 4 & 3 & 3 & 2 & 2 & 2 & 1 & 1 & 1 & 1 & 1 & 1 & 1 & 1 & 1 & 1 & 1 & 1 & 1 & 1 & 1 & 1 & 1 & 1 & 1 & 1 & \\
\hline B1 - reverse & 0.03 & 21 & 12 & 5 & 5 & 2 & 1 & 1 & 1 & 1 & 1 & 1 & 1 & 1 & 1 & & & & & & & & & & & & & & & & & \\
\hline B2 - forward & 0.03 & 78 & 28 & 21 & 7 & 6 & 6 & 5 & 4 & 3 & 3 & 2 & 2 & 2 & 1 & 1 & 1 & 1 & 1 & 1 & 1 & 1 & 1 & 1 & 1 & 1 & 1 & 1 & 1 & 1 & 1 & \\
\hline B2 - reverse & 0.02 & 15 & 10 & 4 & 3 & 1 & 1 & 1 & 1 & 1 & 1 & 1 & 1 & & & & & & & & & & & & & & & & & & & \\
\hline B3 - forward & 0.03 & 56 & 19 & 27 & 9 & 2 & 2 & 2 & 1 & 1 & 1 & 1 & 1 & 1 & 1 & 1 & 1 & 1 & 1 & 1 & 1 & 1 & & & & & & & & & & \\
\hline B3 - reverse & 0.03 & 38 & 22 & 7 & 6 & 5 & 2 & 1 & 1 & 1 & 1 & 1 & 1 & 1 & 1 & 1 & 1 & 1 & 1 & 1 & 1 & 1 & 1 & 1 & 1 & & & & & & & \\
\hline $\begin{array}{l}\text { B1, B2, B3 - } \\
\text { forward }\end{array}$ & 0.03 & 209 & 66 & 46 & 24 & 16 & 14 & 7 & 6 & 6 & 5 & 4 & 4 & 4 & 4 & 3 & 3 & 3 & 2 & 2 & 2 & 2 & 2 & 2 & 2 & 2 & 2 & 1 & 1 & 1 & 1 & $\ldots * *$ \\
\hline $\begin{array}{c}\mathrm{B} 1, \mathrm{~B} 2, \mathrm{~B} 3 \text { - } \\
\text { reverse }\end{array}$ & 0.03 & 74 & 43 & 15 & 7 & 5 & 5 & 3 & 2 & 1 & 1 & 1 & 1 & 1 & 1 & 1 & 1 & 1 & 1 & 1 & 1 & 1 & 1 & 1 & 1 & 1 & 1 & 1 & 1 & 1 & 1 & $\ldots * *$ \\
\hline
\end{tabular}

*Faixa de distância usada para definir a OTU (apresentada em nível de diferença entre as seqüências). **Indica que os números de representantes nas seguintes OTUs é igual a 1.

A análise mostrou que as 75 sequiências forward da B1 foram separadas em 28 OTUs e as 21 seqüências reverse da B1 foram distribuídas em 12 OTUs. A mesma análise também definiu 28 OTUs para as 78 sequiências forward da B2 e 10 OTUs para as 15 sequiências reverse da B2. Assim também, ocorreu para as 56 seqüências forward da B3 (19 OTUs) e para as 38 seqüências reverse da B3 (22 OTUs). Quando as 209 seqüências forward das três bibliotecas foram analisadas juntas foi possível verificar suas distribuições em 66 OTUs e quando a mesma análise foi feita para as sequiências reverse foram observadas 43 OTUs.

Após a distribuição das seqüências de clones em OTUs, apenas uma sequência de cada OTU foi escolhida para representar os demais clones. Cada sequência representante foi comparada, quanto à similaridade através de uma matriz gerada pelo programa Mega 4, com seqüências disponibilizadas nos bancos de dados do RDP II e do GenBank (NCBI). No total, 119 sequiências (40 da biblioteca 1, 38 da biblioteca 2 e 41 da biblioteca 3) foram selecionadas e identificadas para representar os demais clones (Tabelas 7-9). Árvores filogenéticas com esses resultados foram construídas somente para cada uma das três bibliotecas com as seqüências forward, já que os resultados das seqüências reverse foram similares aos que serão apresentados (Figuras 31 a 33). 
Tabela 7 - Representantes dominantes dos clones bacterianos da biblioteca 1 encontrados nas amostras de água do mar coletadas no Canal de São Sebastião no mês de novembro/2006.

\begin{tabular}{|c|c|c|c|c|c|c|}
\hline Filo & Representantes & $\mathbf{N}^{0}$ de clones & $\begin{array}{l}\text { Sequência de clone não cultivado mais próxima } \\
\text { (\% similaridade)* }\end{array}$ & $\begin{array}{c}\mathrm{N}^{\circ} \text { de acesso da sequência de } \\
\text { clone não cultivado mais } \\
\text { próxima }\end{array}$ & Linhagem tipo mais próxima (\% similaridade)** & $\begin{array}{l}\mathrm{N}^{\circ} \text { de acesso da linhagem } \\
\text { tipo mais próxima }\end{array}$ \\
\hline \multirow{15}{*}{ 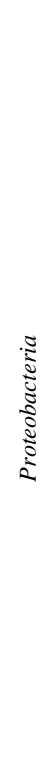 } & B1-forward**** & & & & & \\
\hline & BCA-1 & 24 & Uncultured bacterium clone 6C233285 (100) & EU805285 & Martelella mediterranea (T); MACL11 (84) & AY649762 \\
\hline & BCA-9 & 2 & Uncultured bacterium clone 2uPen D08 (100) & EU627972 & Ruegeria pomeroyi (T); DSS-3 (96) & AF098491 \\
\hline & BCA-13 & 15 & Uncultured bacterium clone S23 1546 (100) & EF573447 & Zymomonas mobilis subsp. mobilis (T); ATCC10988 (87) & AF281031 \\
\hline & BCA-44 & 1 & Uncultured marine bacterium clone C33 (100) & EU010185 & Magnetospirillum magnetotacticum (T); DSM 3856 (91) & Y10110 \\
\hline & BCA-70 & 1 & Uncultured bacterium clone $6 \mathrm{C} 232451(100)$ & EU804513 & Terasakiella pusilla (T); IFO 13613 (88) & AB006768 \\
\hline & BCA- 88 & 1 & Uncultured bacterium clone $6 \mathrm{C} 233226$ (100) & EU805229 & Pleomorphomonas oryzae (T); F-7 (91) & AB159680 \\
\hline & BCA-91 & 1 & Alpha proteobacterium PR52-22 (87) & EU440988 & Rickettsia honei (T); RB (85) & U17645 \\
\hline & BCA-17 & 1 & Uncultured bacterium clone JH-GY37 (98) & DQ537535 & Herbaspirillum lusitanum (T); P6-12 (97) & AF543312 \\
\hline & BCA- 81 & 1 & Uncultured bacterium clone 6C233028 (99) & EU805046 & Methylibium petroleiphilum PM1 (T) (91) & AF176594 \\
\hline & BCA-27 & 1 & Uncultured bacterium clone S25 1030 (99) & EF574686 & Chromohalobacter beijerinckii (T); 3b (90) & AM048787 \\
\hline & BCA-39 & 4 & Uncultured bacterium clone D15 12 SW F1 57 (98) & EU181984 & Reinekea marinisedimentorum (T); DSM 15388 (93) & AJ561121 \\
\hline & BCA- 80 & 3 & Uncultured bacterium clone D15 12 SW F1 57 (98) & EU181984 & Reinekea marinisedimentorum (T); DSM 15388 (94) & AJ561121 \\
\hline & BCA- 84 & 1 & Uncultured bacterium clone C-70 16S (98) & FJ900888 & Pseudomonas plecoglossicida (T); FPC951 (97) & AB009457 \\
\hline & BCA-49 & 1 & Uncultured bacterium clone S25 1072 (100) & EF574728 & Desulfotalea psychrophila (T); LSv54 (87) & AF099062 \\
\hline \multirow{4}{*}{ 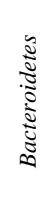 } & BCA-15 & 1 & Uncultured bacterium clone S23 843 (100) & EF572744 & Formosa algae (T); KMM 3553 (93) & AY228461 \\
\hline & BCA-33 & 1 & Uncultured marine bacterium clone C53 (100) & EU010202 & Fluviicola taffensis (T); RW262 (95) & AF493694 \\
\hline & BCA- 47 & 1 & Uncultured bacterium clone 2 uPen A12 (100) & EU627959 & Fluviicola taffensis (T); RW262 (92) & AF493694 \\
\hline & BCA-57 & 1 & Uncultured bacterium clone S25 1677 (100) & EF575333 & Mariniflexile gromovii (T); KMM 6038 (92) & DQ312294 \\
\hline \multirow{4}{*}{ 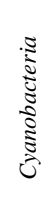 } & BCA-8 & 3 & Uncultured bacterium clone BK 16S (99) & FJ155016 & Anabaena cylindrica (T); NIES19 (PCC7122) (87) & AF091150 \\
\hline & BCA-45 & 1 & Uncultured bacterium clone 3uPen E01 (100) & EU628111 & Anabaena cylindrica (T); NIES19 (PCC7122) (91) & AF091150 \\
\hline & BCA-58 & 1 & Uncultured bacterium clone D2055 (98) & EU258747 & Aphanizomenon flos-aquae (T); PCC 7905 (84) & AY038035 \\
\hline & BCA-77 & 1 & Uncultured bacterium clone MWLSB26 (100) & FJ937846 & $\begin{array}{l}\text { Prochlorococcus marinus subsp. pastoris (T); PCC } 9511 \\
\text { (98) }\end{array}$ & AF180967 \\
\hline
\end{tabular}




\begin{tabular}{|c|c|c|c|c|c|c|}
\hline Filo & Representantes & $\mathbf{N}^{0}$ de clones & $\begin{array}{l}\text { Sequência de clone não cultivado mais próxima } \\
\text { (\% similaridade)* }\end{array}$ & $\begin{array}{l}\mathbf{N}^{\circ} \text { de acesso da sequência de } \\
\text { clone não cultivado mais } \\
\text { próxima }\end{array}$ & Linhagem tipo mais próxima (\% similaridade)** & $\begin{array}{l}\mathrm{N}^{\circ} \text { de acesso da linhagem } \\
\text { tipo mais próxima }\end{array}$ \\
\hline Fusobacteria & BCA-6 & 1 & Uncultured bacterium clone d1-50 (98) & AM409926 & Propionigenium modestum $(\mathrm{T})(95)$ & X54275 \\
\hline Firmicutes & BCA-12 & 1 & Uncultured bacterium clone BA08 (97) & DQ326040 & Roseburia intestinalis (T); L1-82 (98) & AJ312385 \\
\hline \multirow{4}{*}{$\begin{array}{l}\text { Unclassified } \\
\text { Bacteria }\end{array}$} & BCA-25 & 2 & Uncultured bacterium clone S25 1563 (99) & EF575219 & Megasphaera paucivorans (T); VTT E-032341 (78) & DQ223730 \\
\hline & BCA-73 & 1 & Uncultured marine bacterium clone C94 (99) & EU010225 & Megasphaera paucivorans (T); VTT E-032341 (79) & DQ223730 \\
\hline & BCA-21 & 2 & Uncultured bacterium clone 6C233026 (99) & EU805044 & Streptomyces scabrisporus (T); KM-4927 (84) & AB030585 \\
\hline & BCA- 48 & 1 & Uncultured bacterium clone S25 1442 (98) & EF575098 & Caldithrix abyssi (T); LF13T (88) & AJ430587 \\
\hline \multirow{9}{*}{ 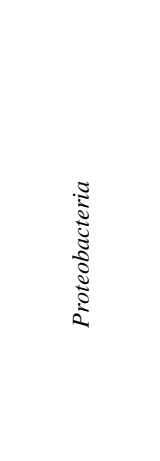 } & B1-reverse ${ }^{* * * * * *}$ & & & & & \\
\hline & BCA-26 & 2 & Uncultured bacterium clone SW94 (99) & FJ809711 & Oceanicola batsensis (T); HTCC2597 (97) & AY424898 \\
\hline & BCA-56 & 1 & Uncultured bacterium clone $1 \mathrm{C} 226885$ (100) & EU799303 & Caedibacter caryophilus (T); 221 (93) & X71837 \\
\hline & BCA-5 & 1 & Uncultured bacterium clone 6C233293 (100) & EU805293 & Methylosarcina quisquiliarum (T); AML-D4 (91) & AF177297 \\
\hline & BCA- 28 & 1 & Pseudomonas sp. SBR3-sapia (100) & EU043321 & Pseudomonas nitroreducens (T); DSM 14399 (100) & AM088474 \\
\hline & $\mathrm{BCA}-2$ & 5 & Uncultured bacterium clone W2-27 (100) & FJ545610 & Saccharibacter floricola (T); S-877 (86) & AB110421 \\
\hline & BCA-7 & 5 & Uncultured bacterium clone 6C232644 (100) & EU804688 & Phaeospirillum fulvum (T); NCIMB11762 (87) & D14433 \\
\hline & BCA-65 & 1 & Uncultured alpha proteobacterium clone SW08 (100) & EU919121 & Tistrella mobilis (T) (86) & AB071665 \\
\hline & BCA-75 & 1 & Uncultured bacterium clone S25 598 (100) & EF574254 & Methylocaldum szegediense (T); OR2 (87) & U89300 \\
\hline \multirow{2}{*}{ Bacteroidetes } & BCA-37 & 1 & Uncultured bacterium clone S25 1408 (100) & EF575064 & Pibocella ponti (T); KMM 6031 (95) & AY576654 \\
\hline & BCA-55 & 1 & Flavobacteriaceae bacterium LE20 (99) & EU391659 & Vitellibacter vladivostokensis (T); KMM3516 (97) & AB071382 \\
\hline Cyanobacteria & BCA-22 & 1 & Uncultured bacterium clone MM3 16S (98) & FJ 809045 & Chlorogloeopsis fritschii PCC 6912 (T) (86) & AB093489 \\
\hline $\begin{array}{l}\text { Unclassified } \\
\text { Bacteria }\end{array}$ & BCA-82 & 1 & $\begin{array}{l}\text { Uncultured bacterium clone SHWN night2 } 16 \mathrm{~S} 635 \\
\qquad(100)\end{array}$ & FJ745123 & Geobacter bremensis (T); Dfr1 (85) & U96917 \\
\hline
\end{tabular}

*A similaridade foi calculada utilizando a matriz do Mega entre os representantes e a sequência do clone não cultivado disponibilizados no banco de dados do NCBI.

** A similaridade foi calculada utilizando a matriz do Mega entre os representantes e a sequência de linhagem tipo disponibilizadas no banco de dados do RDP.

***Clones obtidos da biblioteca 1 com seqüências forward.

**** Clones obtidos da biblioteca 1 com sequiências reverse. 
Tabela 8 - Representantes dominantes dos clones bacterianos da biblioteca 2 encontrados nas amostras de água do mar coletadas no Canal de São Sebastião no mês fevereiro/2006.

\begin{tabular}{|c|c|c|c|c|c|c|}
\hline Filo & Representantes & $\mathbf{N}^{0}$ de clones & $\begin{array}{l}\text { Sequência de clone não cultivado mais próxima } \\
\text { (\% similaridade)* }\end{array}$ & $\begin{array}{c}\mathbf{N}^{\circ} \text { de acesso da sequência de } \\
\text { clone não cultivado mais } \\
\text { próxima }\end{array}$ & $\begin{array}{l}\text { Linhagem tipo mais próxima } \\
\text { (\% similaridade) }{ }^{* * *}\end{array}$ & $\begin{array}{l}\mathrm{N}^{\circ} \text { de acesso da linhagem } \\
\text { tipo mais próxima }\end{array}$ \\
\hline \multirow{15}{*}{ 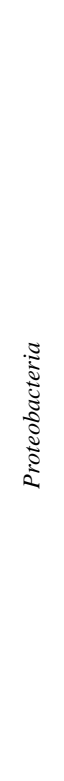 } & B2-forward ${ }^{* * * *}$ & & & & & \\
\hline & BCA-105 & 4 & Uncultured bacterium clone $1 \mathrm{C} 227033$ (100) & EU799434 & Ruegeria pomeroyi (T); DSS-3 (96) & AF098491 \\
\hline & BCA-199 & 1 & Uncultured bacterium clone 2uPen D09 (100) & EU627973 & Ruegeria pomeroyi (T); DSS-3 (97) & AF098491 \\
\hline & BCA-116 & 21 & Uncultured alpha proteobacterium (99) & AJ810784 & Martelella mediterranea (T); MACL11 (86) & AY649762 \\
\hline & BCA-106 & 6 & Uncultured bacterium clone 6C233167 (99) & EU805175 & Zymomonas mobilis subsp. mobilis (T); ATCC10988 (86) & AF281031 \\
\hline & BCA-107 & 3 & Uncultured bacterium clone A714022 (98) & AY907807 & Schlegelella thermodepolymerans (T); K14 (91) & AY152824 \\
\hline & BCA-109 & 1 & $\begin{array}{l}\text { Uncultured Burkholderiales bacterium clone B27 } \\
\text { (98) }\end{array}$ & FJ999599 & Aquabacterium commune (T); B8 (99) & AF035054 \\
\hline & BCA-143 & 1 & Uncultured bacterium clone D15 12 SW F1 90 (98) & EU181997 & Aquabacterium citratiphilum (T); B4 (96) & AF035050 \\
\hline & BCA-157 & 1 & Uncultured bacterium clone 6C233079 (100) & EU805093 & Limnobacter thiooxidans (T); CS-K2 (95) & AJ289885 \\
\hline & BCA-162 & 1 & Uncultured bacterium clone TM18 (99) & AY838532 & Ralstonia insidiosa (T); AU2944 (99) & AF488779 \\
\hline & BCA-103 & 1 & Uncultured bacterium clone VH-FL8-62 (99) & EF379730 & Alteromonas marina $(\mathrm{T}) ; \mathrm{SW}-47$ (95) & AF529060 \\
\hline & BCA-108 & 6 & Uncultured bacterium clone S25 477 (98) & EF574133 & $\begin{array}{l}\text { Saccharospirillum impatiens (T); EL-105 = DSM } 12546 \\
\text { (91) }\end{array}$ & AJ315983 \\
\hline & BCA-111 & 1 & Uncultured marine bacterium clone B81 (100) & EU010152 & Salicola marasensis (T); strain 7Sm5 (90) & DQ019934 \\
\hline & BCA-180 & 1 & Uncultured bacterium clone 4C229885 (98) & EU802543 & Reinekea marinisedimentorum (T); DSM 15388 (91) & AJ561121 \\
\hline & BCA-118 & 2 & Uncultured bacterium clone YK 148 (88) & DQ984636 & Geopsychrobacter electrodiphilus (T); A1 (89) & AY187303 \\
\hline \multirow{4}{*}{ 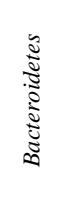 } & BCA-110 & 1 & Uncultured bacterium clone S25 1677 (100) & EF575333 & Mariniflexile gromovii (T); KMM 6038 (93) & DQ312294 \\
\hline & BCA-117 & 1 & Uncultured bacterium clone 3uD B11 (99) & EU628052 & Tenacibaculum maritimum $(\mathrm{T})(89)$ & M64629 \\
\hline & BCA-113 & 1 & Uncultured bacterium clone S25 1408 (99) & EF575064 & Formosa algae (T); KMM 3553 (93) & AY228461 \\
\hline & BCA-153 & 2 & Uncultured marine bacterium clone C53 (100) & EU010202 & Fluviicola taffensis (T); RW262 (95) & AF493694 \\
\hline \multirow{3}{*}{ 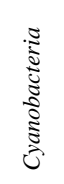 } & BCA-101 & 7 & $\begin{array}{l}\text { Uncultured marine microorganism clone 1605AA } \\
\qquad 92(99)\end{array}$ & EU188418 & $\begin{array}{l}\text { Prochlorococcus marinus subsp. pastoris (T); PCC 9511; } \\
\text { ATCC700925 (98) }\end{array}$ & AF180967 \\
\hline & BCA-173 & 1 & Uncultured bacterium clone MWLSB26 (99) & FJ937846 & $\begin{array}{l}\text { Prochlorococcus marinus subsp. pastoris (T); PCC 9511; } \\
\text { ATCC700925 (98) }\end{array}$ & AF180967 \\
\hline & BCA-124 & 2 & Uncultured bacterium clone 3uPen H04 (99) & EU628131 & Anabaena cylindrica (T); NIES19 (PCC7122) (89) & AF091150 \\
\hline
\end{tabular}




\begin{tabular}{|c|c|c|c|c|c|c|}
\hline \multirow[t]{3}{*}{ Filo } & Representantes & $\mathrm{N}^{\circ}$ de clones & $\begin{array}{l}\text { Sequência de clone não cultivado mais próxima } \\
\text { (\% similaridade)* }\end{array}$ & $\begin{array}{c}\mathrm{N}^{\circ} \text { de acesso da sequência de } \\
\text { clone não cultivado mais } \\
\text { próxima }\end{array}$ & $\begin{array}{l}\text { Linhagem tipo mais próxima } \\
\text { (\% similaridade) }{ }^{* * *}\end{array}$ & $\begin{array}{l}\mathbf{N}^{\circ} \text { de acesso da linhagem } \\
\text { tipo mais próxima }\end{array}$ \\
\hline & BCA-104 & 1 & Uncultured bacterium clone 3uD A09 (99) & EU628046 & Cylindrospermum stagnale (T); ATCC 29204 (91) & AF132789 \\
\hline & BCA-155 & 1 & Uncultured bacterium clone L4808 (100) & EU268102 & Aphanizomenon flos-aquae (T); PCC 7905 (85) & AY038035 \\
\hline Verrucomicrobia & BCA-158 & 1 & Uncultured marine bacterium clone B73 (100) & EU010149 & Opitutus terrae (T); PB90-1 (88) & AJ 229235 \\
\hline Firmicutes & BCA-182 & 1 & Uncultured bacterium clone SJTU D 1549 (99) & EF401879 & Anaerovorax odorimutans (T); NorPut (96) & AJ 251215 \\
\hline \multirow{3}{*}{$\begin{array}{l}\text { Unclassified } \\
\text { Bacteria }\end{array}$} & BCA-151 & 1 & Uncultured bacterium clone S23 965 (98) & EF572866 & Caldithrix abyssi (T); LF13T (87) & AJ430587 \\
\hline & BCA-134 & 3 & Uncultured bacterium clone 6C233026 (96) & EU805044 & Streptomyces scabrisporus (T); KM-4927 (84) & AB030585 \\
\hline & BCA-130 & 5 & Uncultured marine bacterium clone C94 (100) & EU010225 & Geobacter thiogenes $(\mathrm{T})(81)$ & AF223382 \\
\hline \multirow{10}{*}{ 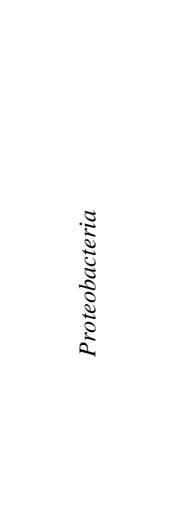 } & B2-reverse ${ }^{* * * * * * * *}$ & & & & & \\
\hline & BCA-102 & 4 & Uncultured bacterium clone 6C232754 (100) & EU804793 & Phaeospirillum fulvum (T); NCIMB11762 (88) & D14433 \\
\hline & BCA-112 & 3 & Uncultured bacterium clone S23 885 (100) & EF572786 & Stella vacuolata (T); DSM5901 (88) & AJ535711 \\
\hline & BCA-128 & 1 & Uncultured bacterium clone 6C232223 (86) & EU804321 & Tistrella mobilis (T) (74) & AB071665 \\
\hline & BCA-144 & 1 & Uncultured bacterium clone MM9 (100) & FJ809051 & Pelagibaca bermudensis (T); HTCC2601 (98) & DQ178660 \\
\hline & BCA-164 & 1 & Uncultured bacterium clone AM58 (100) & FJ809196 & Erythrobacter flavus (T); SW-46 (90) & AF500004 \\
\hline & BCA-169 & 1 & Uncultured bacterium clone $6 \mathrm{C} 232660$ (100) & EU804702 & Acetobacter pomorum (T); LTH2458 (86) & AJ001632 \\
\hline & BCA-161 & 1 & Acidovorax sp. PPs-5 (100) & FJ605421 & Acidovorax temperans (T); CCUG 11779 (100) & AF078766 \\
\hline & BCA-129 & 1 & Uncultured bacterium clone PC-FL10-44 (99) & EF379864 & Methylocaldum szegediense (T); OR2 (88) & U89300 \\
\hline & BCA-184 & 1 & Uncultured bacterium clone 6C233293 (98) & EU805293 & Rhabdochromatium marinum (T) (88) & $\mathrm{X} 84316$ \\
\hline Bacteroidetes & BCA-183 & 1 & Bacterium clone w1cb6 (99) & DQ416609 & Tenacibaculum skagerrakense (T); D30 (99) & AF469612 \\
\hline
\end{tabular}

*A similaridade foi calculada utilizando a matriz do Mega entre os representantes e a sequência do clone não cultivado disponibilizados no banco de dados do NCBI. ** A similaridade foi calculada utilizando a matriz do Mega entre os representantes e a sequência de linhagem tipo disponibilizadas no banco de dados do RDP.

***Clones obtidos da biblioteca 2 com seqüências forward.

**** Clones obtidos da biblioteca 2 com seqüências reverse. 
Tabela 9 - Representantes dominantes dos clones bacterianos da biblioteca 3 encontrados nas amostras de água do mar coletadas no Canal de São Sebastião no mês de fevereiro/2007.

\begin{tabular}{|c|c|c|c|c|c|c|}
\hline Filo & Representantes & $\mathbf{N}^{\circ}$ de clones & $\begin{array}{l}\text { Sequência de clone não cultivado mais próxima (\% } \\
\text { similaridade)* }\end{array}$ & $\begin{array}{l}\mathrm{N}^{\circ} \text { de acesso da sequência de } \\
\text { clone não cultivado mais } \\
\text { próxima }\end{array}$ & $\begin{array}{l}\text { Linhagem tipo mais próxima } \\
\text { (\% similaridade)*** }\end{array}$ & $\begin{array}{l}\mathrm{N}^{\circ} \text { de acesso da linhagem } \\
\text { tipo mais próxima }\end{array}$ \\
\hline \multirow{12}{*}{ 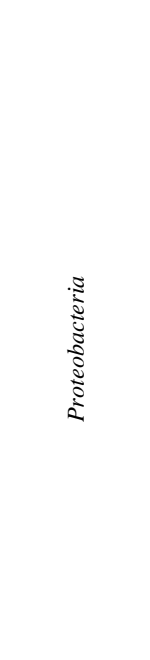 } & B3-forward $* * * *$ & & & & & \\
\hline & BCA-203 & 27 & Uncultured alpha proteobacterium isolate S1 (99) & AJ810784 & Martelella mediterranea (T); MACL11 (85) & AY649762 \\
\hline & BCA-208 & 9 & Uncultured bacterium clone 6C232471 (99) & EU804528 & Bradyrhizobium betae (T); PL7HG1 (86) & AY372184 \\
\hline & BCA-212 & 1 & Uncultured bacterium clone S25 1032 (99) & EF574688 & Roseomonas fauriae (T); strain ATCC 49958 (92) & AY150046 \\
\hline & BCA-229 & 1 & Uncultured bacterium clone 6C232451 (100) & EU804513 & Terasakiella pusilla (T); IFO 13613 (87) & АВ006768 \\
\hline & BCA-258 & 1 & Uncultured bacterium clone 2uPen F07 (100) & EU627982 & Ruegeria pomeroyi (T); DSS-3 (97) & AF098491 \\
\hline & BCA-291 & 1 & Uncultured bacterium clone 2 uPen F07 (100) & EU804088 & Agrobacterium tumefaciens (T) (84) & M11223 \\
\hline & BCA-293 & 1 & $\begin{array}{l}\text { Uncultured marine microorganism clone 4035AA } 68 \\
\qquad(100)\end{array}$ & EU187996 & Rhodopseudomonas palustris (T); ATCC 17001 (87) & D12700 \\
\hline & BCA-201 & 1 & Uncultured bacterium clone 6C233028 (99) & EU805046 & Schlegelella thermodepolymerans (T); K14 (91) & AY152824 \\
\hline & BCA-256 & 2 & Uncultured bacterium clone 1C227067 (100) & EU799464 & Reinekea marinisedimentorum (T); DSM 15388 (92) & AJ561121 \\
\hline & BCA-286 & 1 & Uncultured marine bacterium clone B81 (95) & EU010152 & Microbulbifer maritimus (T); TF-17 (92) & AY377986 \\
\hline & BCA-287 & 1 & $\begin{array}{l}\text { Uncultured marine microorganism clone 40997AA } \\
\qquad 95 \text { (97) }\end{array}$ & FJ189872 & Geopsychrobacter electrodiphilus (T); A1 (89) & AY187303 \\
\hline Bacteroidetes & BCA-222 & 2 & $\begin{array}{l}\text { Uncultured Bacteroidetes bacterium clone MSB- } \\
\text { 5B11 (97) }\end{array}$ & DQ811912 & Fluviicola taffensis (T); RW262 (93) & AF493694 \\
\hline Chloroflexi & BCA-224 & 1 & Uncultured bacterium clone FRC-A2 446 (90) & EF507995 & Anaerolinea thermophila (T); UNI-1 (90) & AB046413 \\
\hline \multirow{7}{*}{$\begin{array}{l}\text { Unclassified } \\
\text { Bacteria }\end{array}$} & BCA-215 & 1 & Uncultured bacterium clone S25 1074 (81) & EF574730 & Anabaena cylindrica (T); NIES19 (PCC7122) (76) & AF091150 \\
\hline & BCA-221 & 2 & Uncultured bacterium clone A713805 (98) & AY907792 & Pelobacter propionicus (T); OttBd1 DSM2379 (82) & X70954 \\
\hline & BCA-225 & 1 & Uncultured bacterium clone CK 1C2 58 (89) & EU487961 & Geopsychrobacter electrodiphilus (T); A1 (80) & AY187303 \\
\hline & BCA-237 & 1 & Uncultured bacterium clone S25 114 (100) & EF573770 & Caldithrix abyssi (T); LF13T (84) & AJ430587 \\
\hline & BCA-245 & 1 & Uncultured bacterium clone S25 1 (98) & EF573657 & Caldithrix abyssi (T); LF13T (85) & AJ430587 \\
\hline & BCA-292 & 1 & Uncultured bacterium clone A714018 (99) & AY907803 & Caldithrix abyssi (T); LF13T (83) & AB003935 \\
\hline & 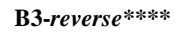 & & & & & \\
\hline
\end{tabular}




\begin{tabular}{|c|c|c|c|c|c|c|}
\hline Filo & Representantes & $\mathbf{N}^{0}$ de clones & $\begin{array}{l}\text { Sequência de clone não cultivado mais próxima (\% } \\
\text { similaridade)* }\end{array}$ & $\begin{array}{l}\mathbf{N}^{\circ} \text { de acesso da sequência de } \\
\text { clone não cultivado mais } \\
\text { próxima }\end{array}$ & $\begin{array}{l}\text { Linhagem tipo mais próxima } \\
\text { (\% similaridade) }{ }^{* * *}\end{array}$ & $\begin{array}{l}\mathrm{N}^{\circ} \text { de acesso da linhagem } \\
\text { tipo mais próxima }\end{array}$ \\
\hline \multirow{14}{*}{ 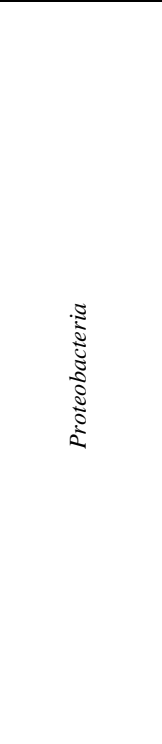 } & BCA-202 & 5 & Uncultured bacterium clone 6C232323 (100) & EU804407 & Ochrobactrum gallinifaecis (T); Iso 196 (87) & AJ519939 \\
\hline & BCA-205 & 7 & Uncultured bacterium clone 6C233115 (99) & EU805126 & Saccharibacter floricola (T); S-877 (83) & AB110421 \\
\hline & BCA-216 & 1 & Uncultured bacterium clone 6C232648 (100) & EU804691 & Stella vacuolata (T); DSM5901 (86) & AJ535711 \\
\hline & BCA-232 & 1 & Uncultured bacterium clone 3C002754 (95) & EU801459 & Ancylobacter vacuolatus (T); DSM 1277 (84) & AY211515 \\
\hline & BCA-239 & 1 & Uncultured marine bacterium clone Surf1.19 (100) & DQ071144 & Tistrella mobilis (T) (86) & AB071665 \\
\hline & BCA-255 & 1 & Uncultured bacterium clone S23 1157 (100) & EF573058 & Tistrella mobilis (T) (86) & AB071665 \\
\hline & BCA-207 & 6 & Uncultured bacterium clone 6C233351 (100) & EU805347 & Phaeospirillum fulvum (T); NCIMB11762 (85) & D14433 \\
\hline & BCA-244 & 1 & Uncultured bacterium clone 6C232528 (99) & EU804579 & Phaeospirillum fulvum (T); NCIMB11762 (85) & D14433 \\
\hline & BCA-274 & 1 & Uncultured bacterium clone 6C232448 (100) & EU804510 & Phaeospirillum fulvum (T); NCIMB11762 (86) & D14433 \\
\hline & BCA-233 & 2 & Uncultured bacterium clone 6C231986 (100) & EU804094 & Methylosarcina fibrata (T); AML-C10 (88) & AF177296 \\
\hline & BCA-247 & 1 & $\begin{array}{l}\text { Uncultured gamma proteobacterium clone SHWN } \\
\text { night2 16S } 396(100)\end{array}$ & FJ745206 & Shewanella baltica (T); NCTC 10735 (88) & AJ000214 \\
\hline & BCA-253 & 1 & Uncultured bacterium clone S1-17 (100) & FJ545449 & Thioalkalivibrio thiocyanodenitrificans (T); ARhD 1 (94) & AY360060 \\
\hline & BCA-264 & 1 & Uncultured bacterium clone TLC-FL2-28 (100) & EF379476 & Marinospirillum alkaliphilum (T); Z4 (90) & AF275713 \\
\hline & BCA-284 & 1 & Uncultured marine bacterium clone B29 (100) & EU010141 & Lamprocystis purpurea (T); DSM 4197 (90) & AJ223235 \\
\hline \multirow{2}{*}{ Cyanobacteria } & BCA-231 & 1 & $\begin{array}{l}\text { Uncultured marine microorganism clone 1533AA } 68 \\
(98)\end{array}$ & EU188296 & $\begin{array}{r}\text { Prochlorococcus marinus subsp. pastoris (T); PCC } 9511 \\
(95)\end{array}$ & AF180967 \\
\hline & BCA-280 & 1 & Uncultured bacterium clone MM3 (99) & FJ809045 & Chlorogloeopsis fritschii (T); PCC 6912 (84) & АВ093489 \\
\hline \multirow{6}{*}{$\begin{array}{l}\text { Unclassified } \\
\text { Bacteria }\end{array}$} & BCA-204 & 1 & Uncultured bacterium clone 6C232471 (99) & EU804528 & Ochrobactrum gallinifaecis (T); Iso 196 (86) & AJ519939 \\
\hline & BCA-251 & 1 & Uncultured bacterium clone 6C233076 (100) & EU805091 & Geobacter bremensis (T); Dfr1 (87) & U96917 \\
\hline & BCA-266 & 1 & Uncultured marine bacterium clone $\mathrm{C} 7$ (99) & EU010211 & Desulfobacterium anilini (T); DSM 4660 (82) & AY835388 \\
\hline & BCA-271 & 1 & $\begin{array}{c}\text { Uncultured bacterium clone SHWN night2 } 16 \mathrm{~S} 635 \\
(99)\end{array}$ & FJ745123 & Geobacter bremensis (T); Dfr1 (84) & U96917 \\
\hline & BCA-273 & 1 & $\begin{array}{l}\text { Uncultured bacterium clone } 051011 \text { T3S4 W T SDP } \\
151(97)\end{array}$ & FJ349968 & Desulfuromonas svalbardensis (T); 112 (89) & AY835388 \\
\hline & BCA-298 & 1 & Uncultured bacterium clone P9X2b3B05 (96) & EU491100 & Desulfuromonas thiophila (T); NZ27 (DSMZ 8987) (90) & Y11560 \\
\hline
\end{tabular}

*A similaridade foi calculada utilizando a matriz do Mega entre os representantes e a sequência do clone não cultivado disponibilizados no banco de dados do NCBI. ** A similaridade foi calculada utilizando a matriz do Mega entre os representantes e a sequência de linhagem tipo disponibilizadas no banco de dados do RDP.

***Clones obtidos da biblioteca 3 com seqüências forward. / **** Clones obtidos da biblioteca 3 com seqüências reverse. 


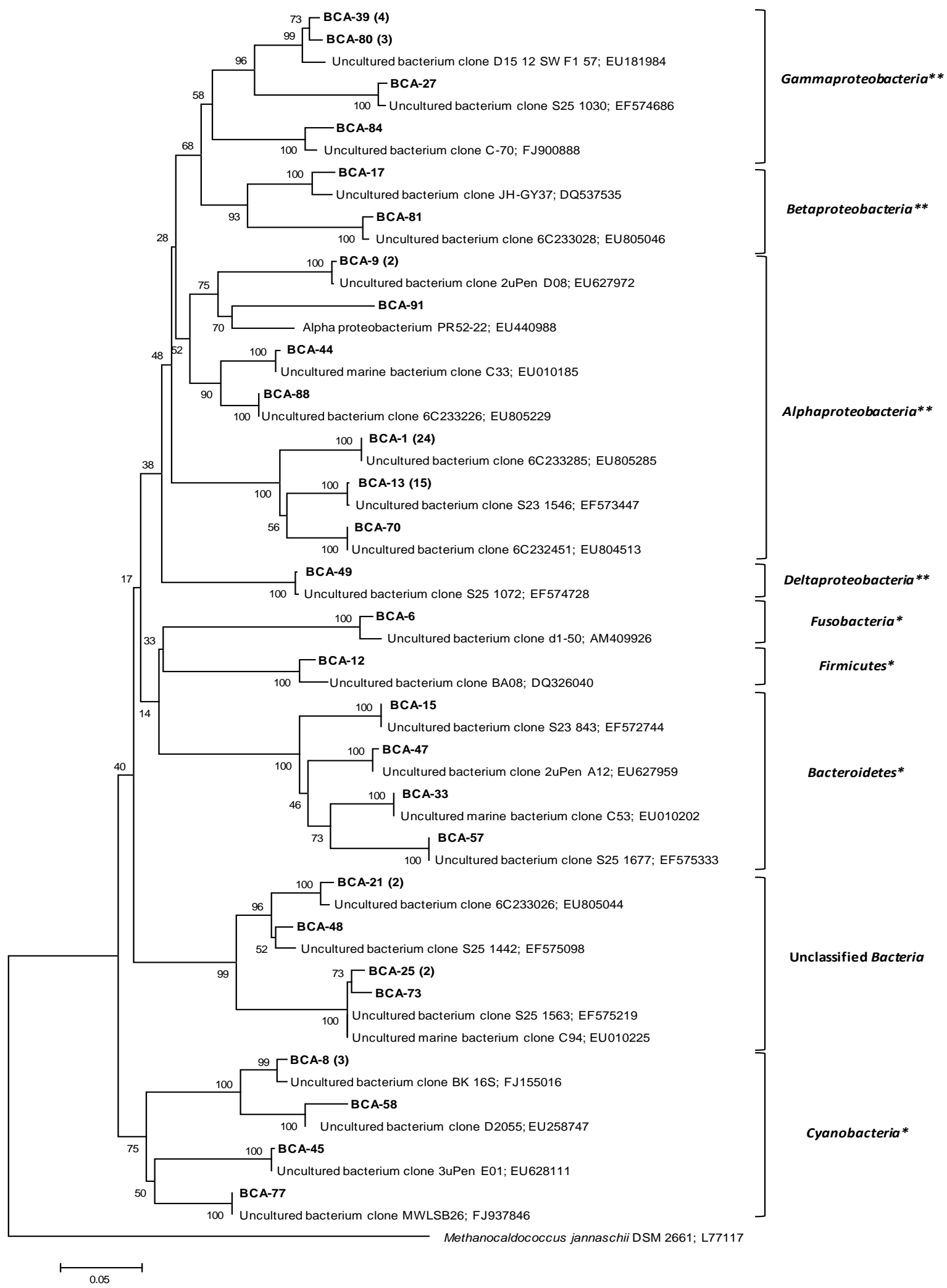

Figura 31 - Árvore filogenética construída com as 28 sequiências forward representantes dos clones da biblioteca 1 e seqüências referência. A sequência Methanocaldococcus jannaschii foi utilizada como grupo externo para enraizamento da árvore. Somente os valores de bootstrap que estavam acima de 50 foram mostrados. BMV-...: clones representantes cada OTU; ( ): número de seqüências de clones com identidade de 97\%. Classificação filogenética: Filo $(*)$, Classe $(* *)$. 


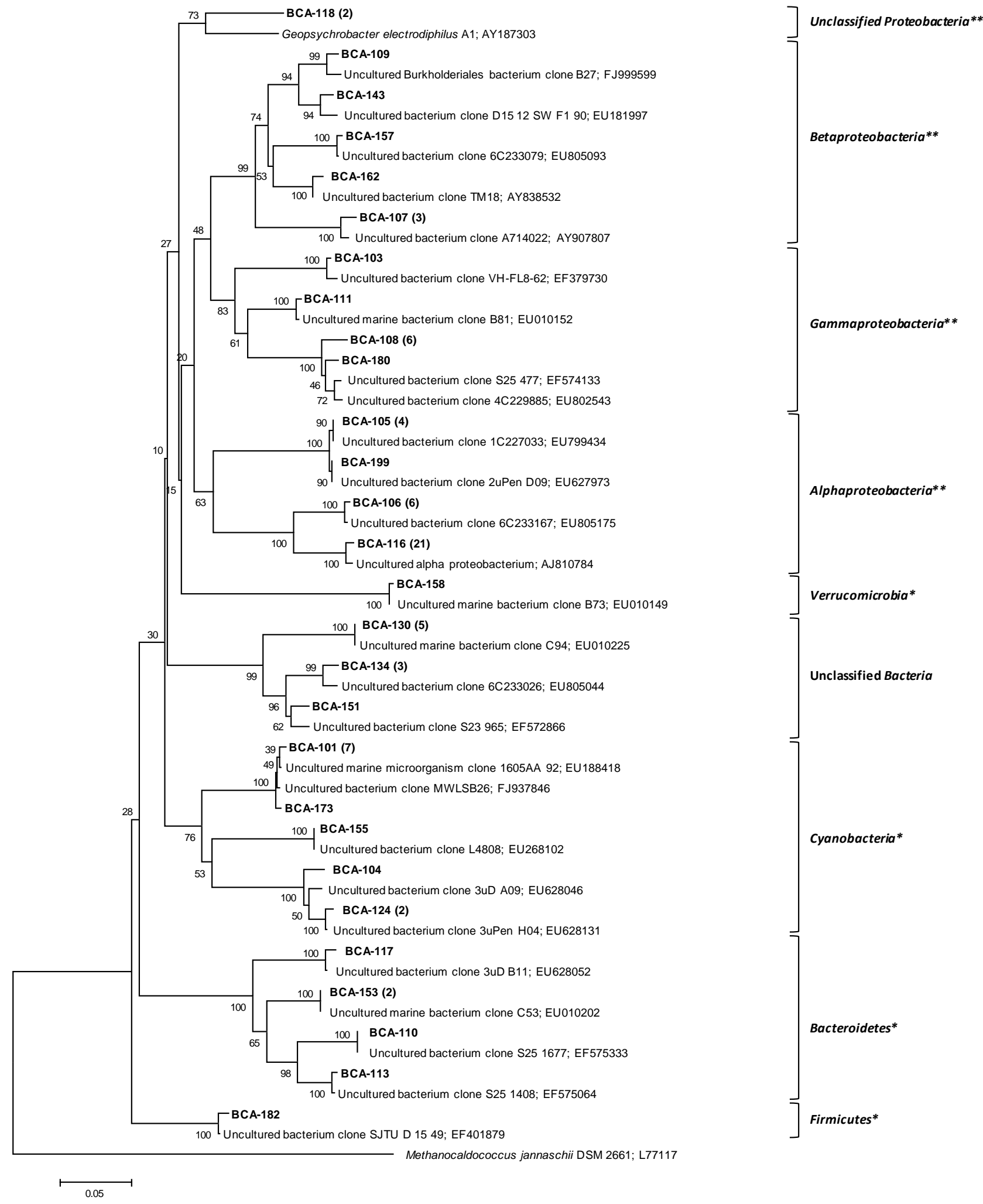

Figura 32 - Árvore filogenética construída com as 28 sequiências forward representantes dos clones da biblioteca 2 e seqüências referência. A sequência Methanocaldococcus jannaschii foi utilizada como grupo externo para enraizamento da árvore. Somente os valores de bootstrap que estavam acima de 50 foram mostrados. BMV-..: clones representantes cada OTU; ( ): número de sequiências de clones com identidade de 97\%. Classificação filogenética: Filo (*), Classe (**). 


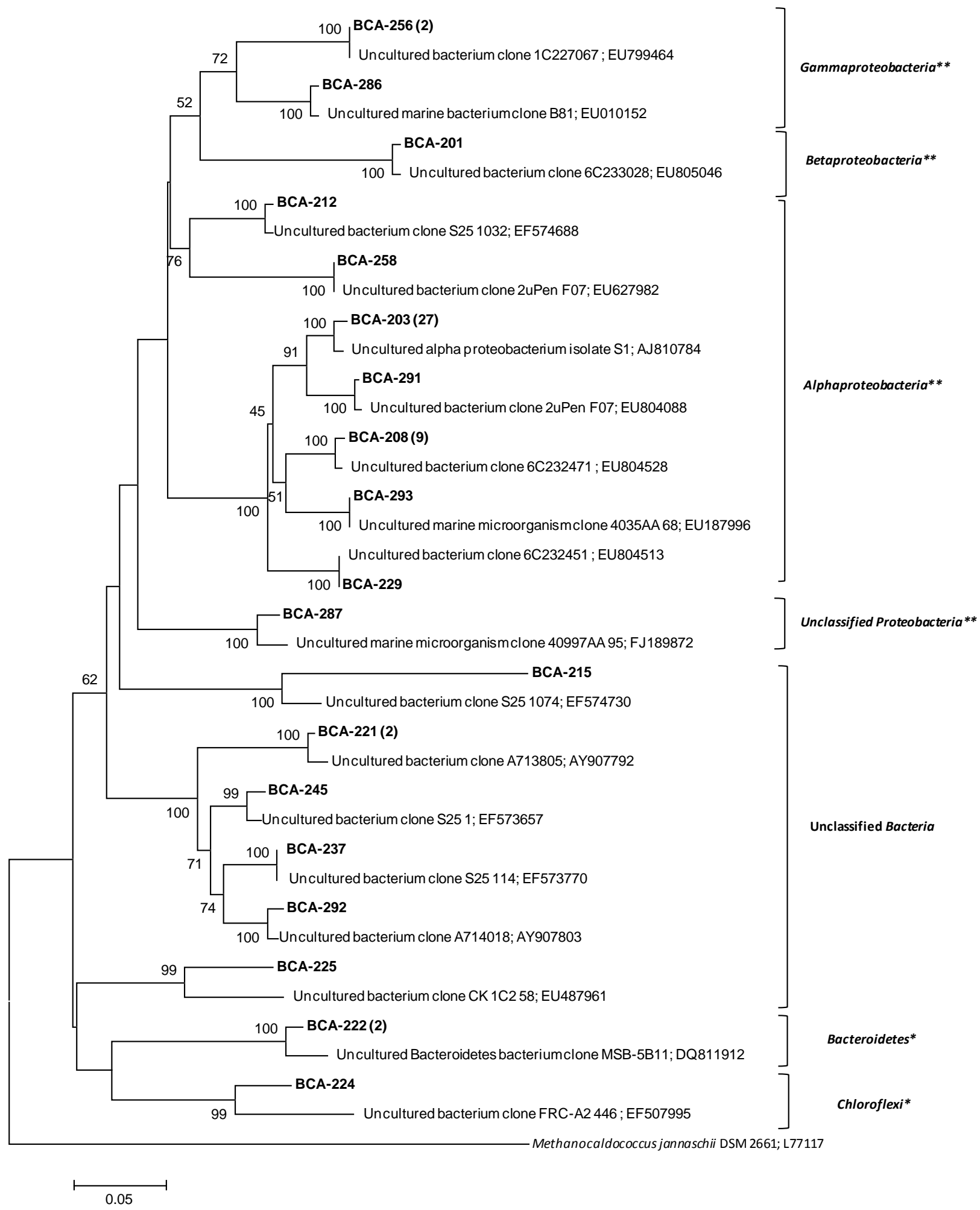

Figura 33 - Árvore filogenética construída com as 19 sequiências forward representantes dos clones da biblioteca 3 e seqüências referência. A sequência Methanocaldococcus jannaschii foi utilizada como grupo externo para enraizamento da árvore. Somente os valores de bootstrap que estavam acima de 50 foram mostrados. BMV-...: clones representantes cada OTU; ( ): número de seqüências de clones com identidade de 97\%. Classificação filogenética: Filo (*), Classe (**). 
Utilizando o limite de confiança de $80 \%$, as seqüências foram identificadas no Classifier e foi observado que, tanto as seqüências forward como as reverse dos clones da biblioteca 1, pertenceram a 5 filos (Proteobacteria, Bacteroidetes, Cyanobacteria, Firmicutes e Fusobacteria), com predominância do filo Proteobacteria $(77,1 \%)$. No entanto, 7,3\% (n = 7) de todas as seqüências bacterianas não puderam ser classificadas quanto ao nível de filo, sendo denominadas Unclassified Bacteria (Figura 34 A).

As análises comparativas das 78 seqüências forward e 15 reverse da biblioteca 2 permitiu verificar que os 96 clones se distribuíram dentro dos mesmos filos que os clones da biblioteca 1, com exceção do Filo Fusobacteria que não foi detectado, mas, em contrapartida, o Filo Verrucomicrobia foi encontrado. Nesta biblioteca 10,7\% das sequiências bacterianas identificadas também não tiveram um filo definido (Unclassified Bacteria) (Figura 34 B).

Foram identificados nas sequiências (forward e reverse) da biblioteca 3 clones pertencentes a 4 filos (Proteobacteria, Bacteroidetes, Chloroflexi e Cyanobacteria) e nessa biblioteca o número de seqüências bacterianas que não foram classificadas em nenhum filo foi de $14,9 \%$ (Figura $34 \mathrm{C}$ ).

Apesar das 283 sequiências de clones das três bibliotecas terem sido distribuídas em sete filos diferentes (Proteobacteria, Bacteroidetes, Cyanobacteria, Firmicutes, Fusobacteria, Verrucomicrobia e Chloroflexi), aproximadamente, $75 \%(\mathrm{n}=212)$ dos clones pertenceram ao Filo Proteobacteria.

Além do filo Proteobacteria, os outros filos que apareceram com maiores freqüências foram os Bacteroidetes (6,3\%) e Cyanobacteria (7,3\%) na biblioteca 1. Contudo, estes três filos aparecem com frequiências diferentes. Similarmente ocorreu na biblioteca 2, apesar do filo Cyanobacteria ter aparecido com freqüência superior (12,9\%) à biblioteca 1 . A exceção ficou com a biblioteca 3 , onde o filo Proteobacteria foi o único que predominou $(79,8 \%)$, deixando os outros três filos com, aproximadamente, $5 \%$ da representação dessas sequiências de clones.

Vale repetir que a presença de filos comuns nas bibliotecas foi verificada, ainda que da mesma maneira alguns filos (Verrucomicrobia e Chloroflexi) tenham sido específicos das bibliotecas 2 e 3, respectivamente (Figura 35). 
A

B
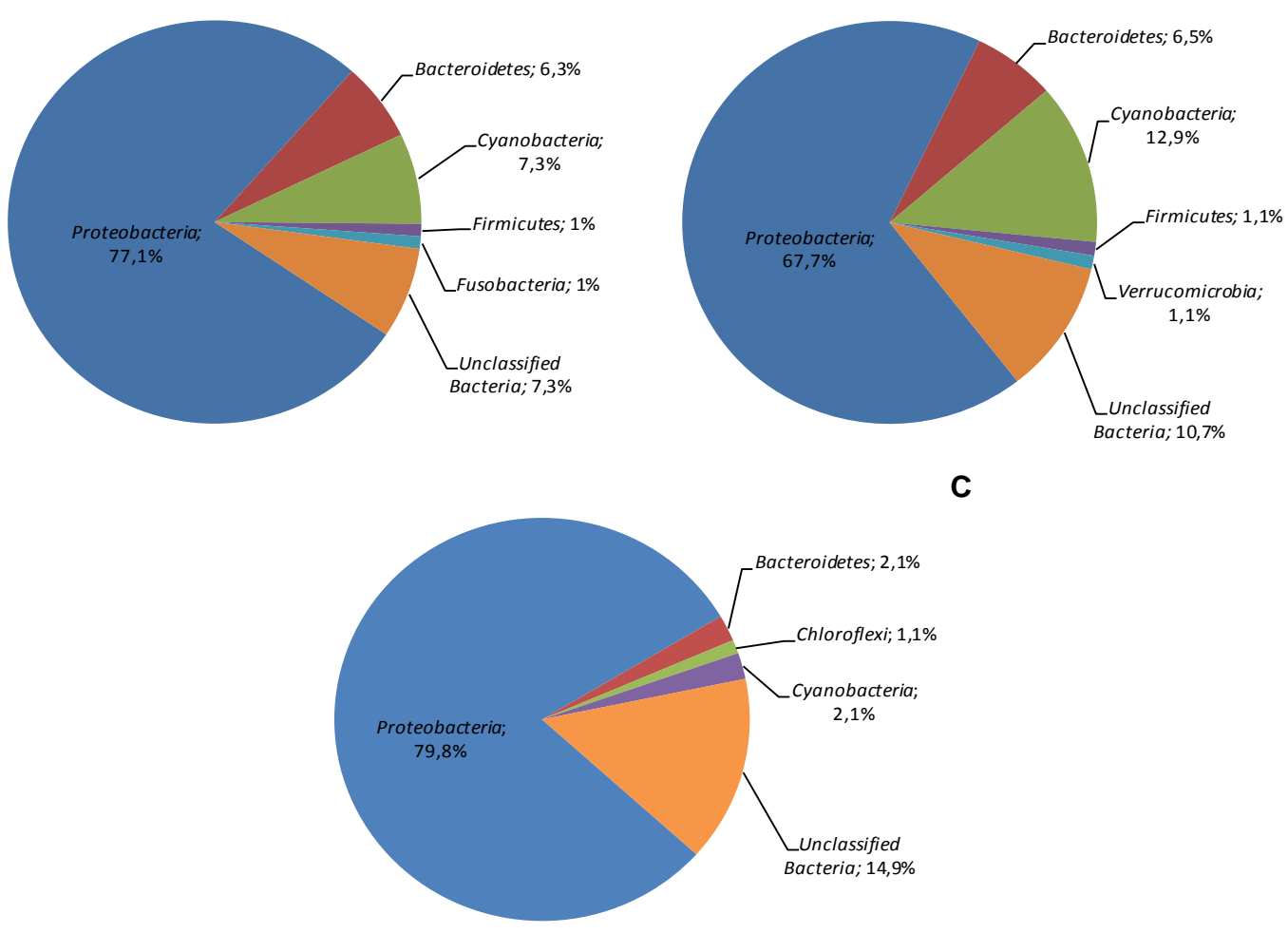

Figura 34 - Freqüência dos filos bacterianos identificados pelo seqüenciamento parcial do gene $16 \mathrm{~S}$ rDNA dos clones das bibliotecas. A: biblioteca 1 (novembro/2006); B: biblioteca 2 (fevereiro/2006); C: biblioteca 3 (fevereiro/2007). As seqüências foram identificadas através do Classifier no RDP utilizando o limite de confiança de $80 \%$.

Nota: Os gráficos foram construídos com os resultados das sequências forward e reverse.

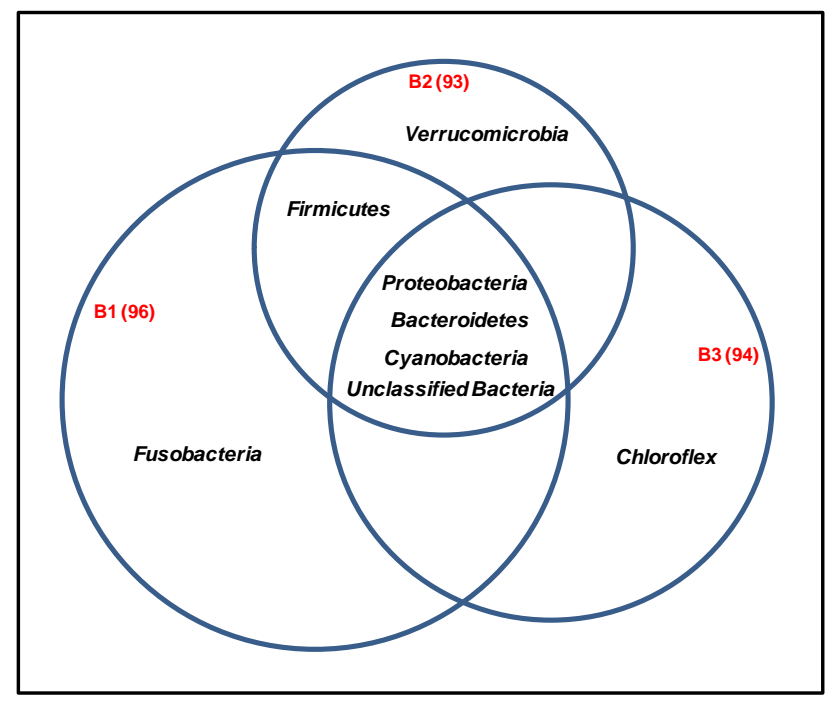

Figura 35 - Distribuição dos filos bacterianos em cada biblioteca. O tamanho dos círculos é proporcional ao número de clones em cada biblioteca, os quais estão mostrados entre parênteses. B1: biblioteca 1 (novembro/2006); B2: biblioteca 2 (fevereiro/2006); B3: biblioteca 3 (fevereiro/2007).

Nota: Os resultados equivalem as sequências forward e reverse. 
Analisando agora a composição das três bibliotecas, em relação às classes bacterianas foi verificado que três classes (alpha-, beta-, gammaproteobacteria) dentro do filo Proteobacteria estiveram presentes, mas não necessariamente nas três bibliotecas nem com a mesma frequiência. No entanto, alguns clones foram identificados como pertencentes a essas classes, mas não foram classificados dentro de nenhuma ordem específica (Unclassified Alphaproteobacteria, Unclassified Betaproteobacteria, Unclassified Gammaproteobacteria, Unclassified Deltaproteobacteria). A maior freqüência de clones não classificados (Unclassified) ocorreu dentro da classe Alphaproteobacteria, sendo 37,1\% para a biblioteca 1, $27,7 \%$ para a biblioteca 2 e $8,7 \%$ para a biblioteca 3 . Similarmente, $25,9 \%$ dos clones da biblioteca 1, 19,3\% da biblioteca 2 e 72,4\% da biblioteca 3 não puderam ser classificados dentro de nenhuma das classes pertencentes a Proteobacteria, sendo denominado de Unclassified proteobacteria.

As classes Flavobacteria e Cyanobacteria também foram identificadas nas três bibliotecas e suas freqüências em cada biblioteca foram, na ordem em que foram mencionadas no texto: $6,8 \%$ e $7,9 \%$ na biblioteca $1 ; 7,2 \%$ e $14,5 \%$ na biblioteca $2 ; 2,5 \%$ nas duas classes na biblioteca 3 .

Outras classes, com frequiência inferior a $2 \%$, foram identificadas na biblioteca 1 (Clostridia e Fusobacteria), biblioteca 2 (Clostridia e Verrucomicrobiae) e biblioteca 3 (Unclassified Anaerolinea). A figura 36 ilustra a distribuição dessas classes dentro das três bibliotecas.

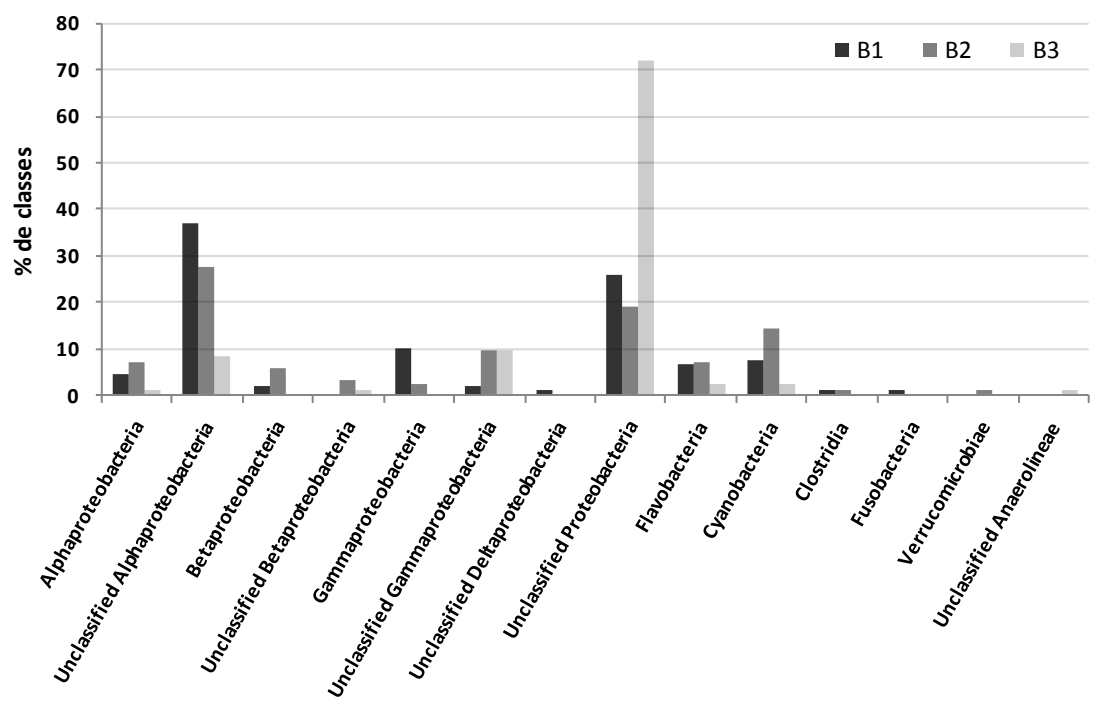

Figura 36 - Freqüência das classes bacterianas identificadas pelo seqüenciamento parcial do gene 16S rDNA dos clones das três bibliotecas de água do mar do Canal de São Sebastião. As seqüências foram identificadas através do Classifier no RDP utilizando o limite de confiança de $80 \%$. 


\subsubsection{1 Índices de Diversidade e Riqueza das bibliotecas gênicas}

Para análise da diversidade, distribuição e abundância das amostras de clones de $16 \mathrm{~S}$ foi utilizado o programa DOTUR, o qual gerou os dados de rarefação, estimativa de riqueza de Chao1 e de ACE, além do índice de diversidade de Shannon $\left(H^{\prime}\right)$, considerando diferentes níveis de similaridades (cutoff) entre as seqüências (97\%, 95\% e 80\%) que determinam espécies, gêneros e filo, respectivamente. Estas análises foram feitas utilizando matrizes de similaridades geradas com o alinhamento das seqüências de clones, aplicando a distância de Jukes-Cantor.

A princípio, fez-se uma análise comparativa entre os resultados gerados nos 3 níveis de similaridade considerados $(97 \%, 95 \%$ e 80\%). A faixa de $100 \%$ de similaridade foi adicionada às análises para a verificação do comportamento da mesma. Considerando as sequiências forward, as curvas de rarefação mostram que, utilizando um cutoff de $80 \%$, as sequiências amostradas em cada uma das bibliotecas foram suficientes para representar a comunidade bacteriana do Canal de São Sebastião, lembrando que cada biblioteca representa a comunidade local em 3 meses diferentes (novembro/2006, fevereiro/2006 e fevereiro/2007) (Figura 37 A-C).

Tendo como base o local amostrado e não mais os meses em questão, foi possível observar o mesmo resultado quando as 3 bibliotecas foram analisadas ao mesmo tempo considerando os diferentes níveis de similaridades (Figura 37 D). 
A

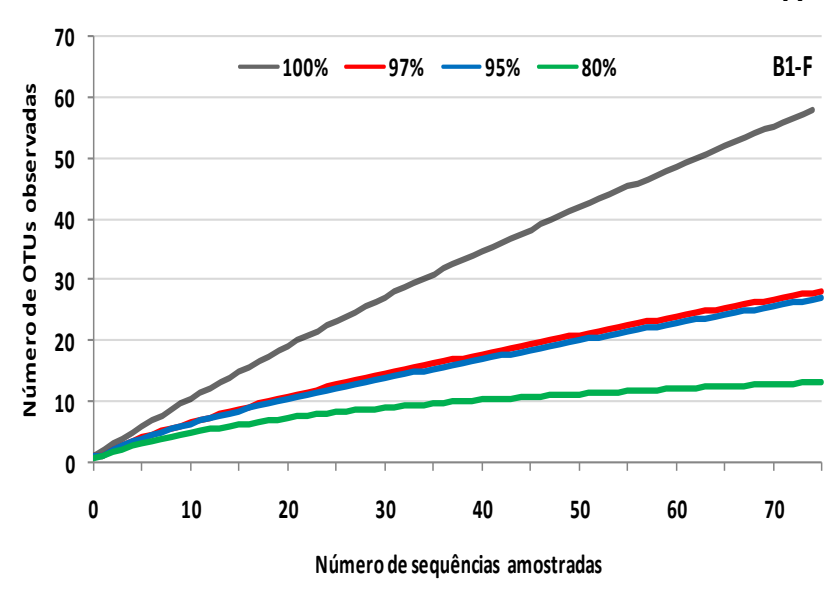

C

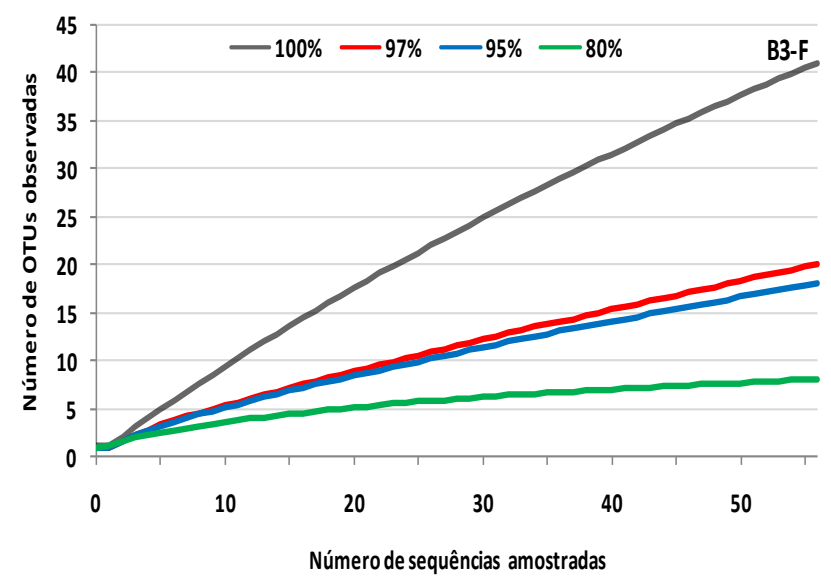

B

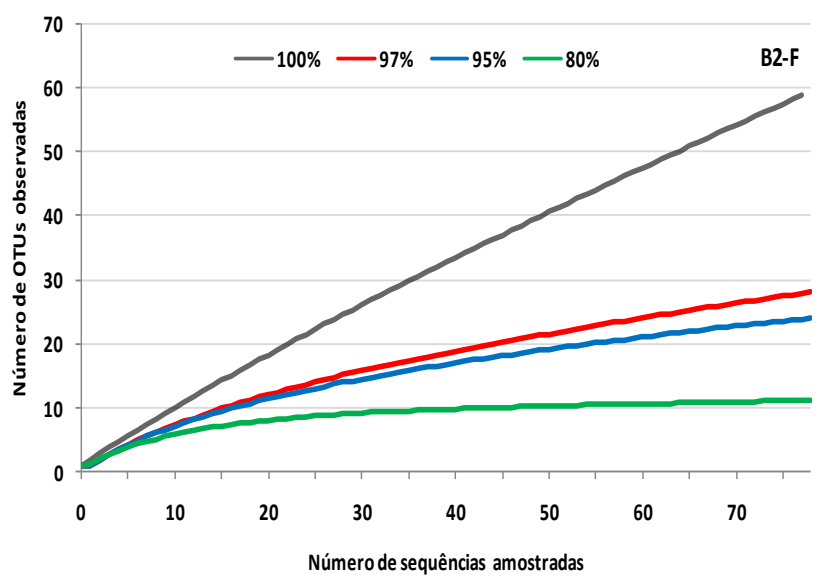

D

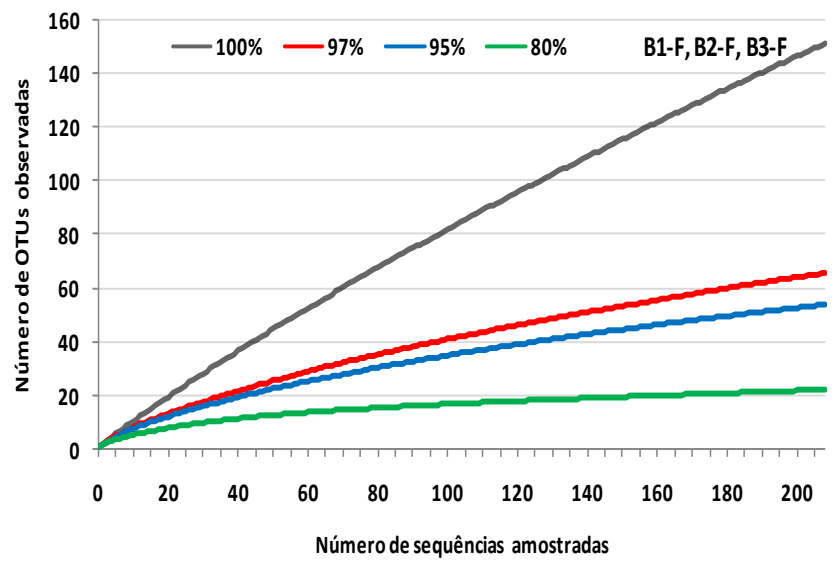

Figura 37 - Análise de rarefação dos clones constituídos pelas seqüências forward das bibliotecas construídas a partir do DNA de amostras de água do mar do Canal de São Sebastião em vários níveis de similaridade taxonômica. As análises são baseadas em seqüências parciais do gene 16S rDNA. A: curva de rarefação da biblioteca 1 (novembro/2006); B: curva de rarefação da biblioteca 2 (fevereiro/2006); C: curva de rarefação da biblioteca 3 (fevereiro/2007); D: curva de rarefação das três bibliotecas. O intervalo de confiança foi de $95 \%$.

Em se tratando das análises das sequiências reverse, embora estas tenham sido em número menor comparadas aos números de OTUs das seqüências forward das bibliotecas, as curvas de rarefação demonstraram os mesmos resultados nos níveis de similaridades descritos (Figura 38 A-D). No entanto, pôde-se verificar que com as seqüências reverse da biblioteca 1 não foi possível definir os números de OTUs para o nível de similaridade de $95 \%$ e para a seqüências reverse da biblioteca 2 o nível de similaridade mais próximo obtido para definição de gêneros foi o de $93 \%$. 
A

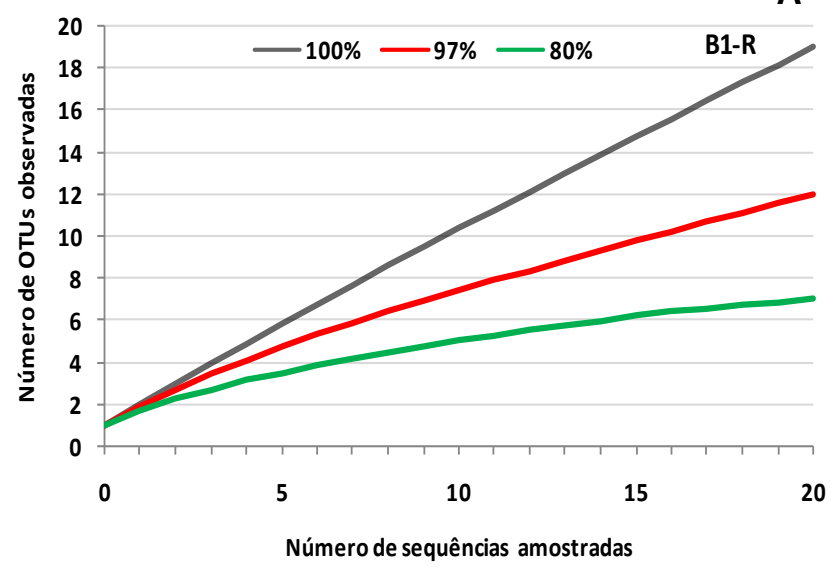

C

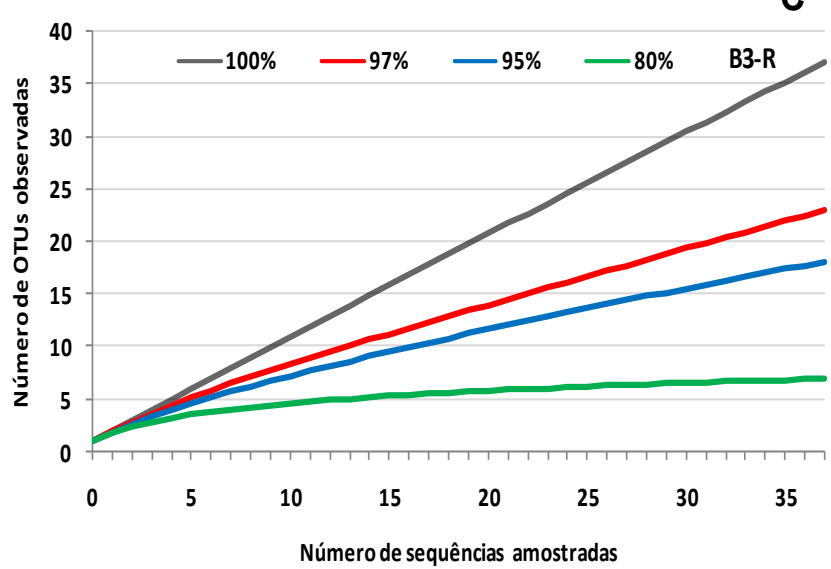

B

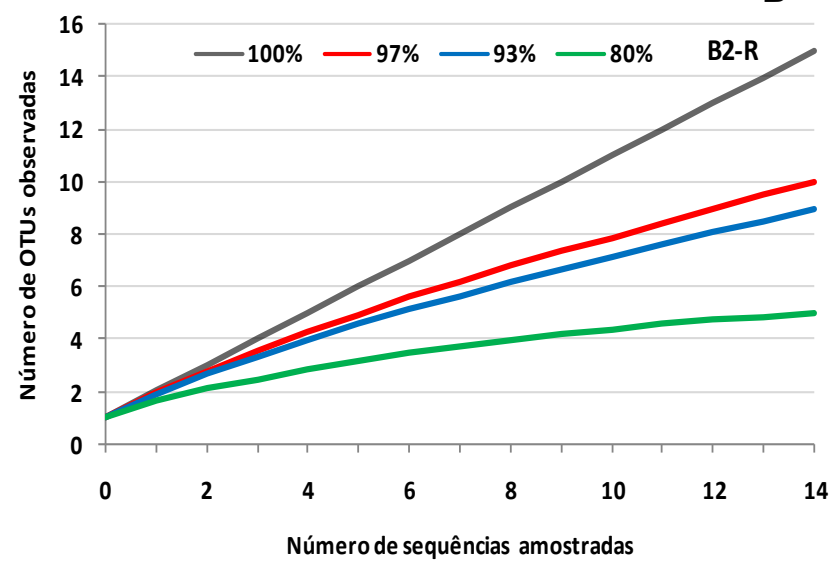

D

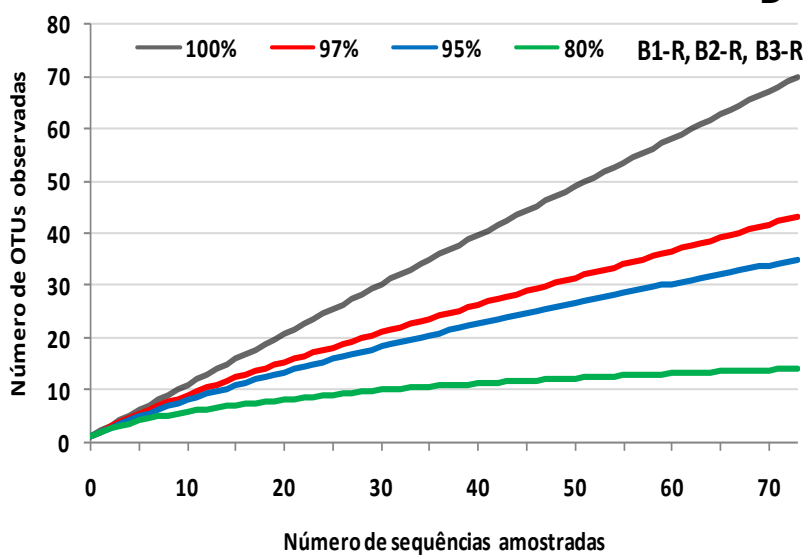

Figura 38 - Análise de rarefação dos clones constituídos pelas sequiências reverse das bibliotecas construídas a partir do DNA de amostras de água do mar do Canal de São Sebastião em vários níveis de similaridade taxonômica. As análises são baseadas em seqüências parciais do gene 16S rDNA. A: curva de rarefação da biblioteca 1 (novembro/2006); B: curva de rarefação da biblioteca 2 (fevereiro/2006); C: curva de rarefação da biblioteca 3 (fevereiro/2007); D: curva de rarefação das três bibliotecas. O intervalo de confiança foi de $95 \%$.

As figuras a seguir mostram as curvas de rarefação das três bibliotecas juntas, onde pode ser verificada a distribuição das OTUs nos diferentes níveis de similaridades considerados. A curva de rarefação gerada com as seqüências forward dos clones indicam que, diante do número de seqüências amostradas $(\mathrm{B} 1=75, \mathrm{~B} 2=78$ e B3 $=56)$ em cada uma das três bibliotecas, foi possível observar uma melhor cobertura da comunidade no que se refere ao maior nível taxonômico (Filo) definido pelo índice de $80 \%$ de similaridade (Figura $39)$. 
A

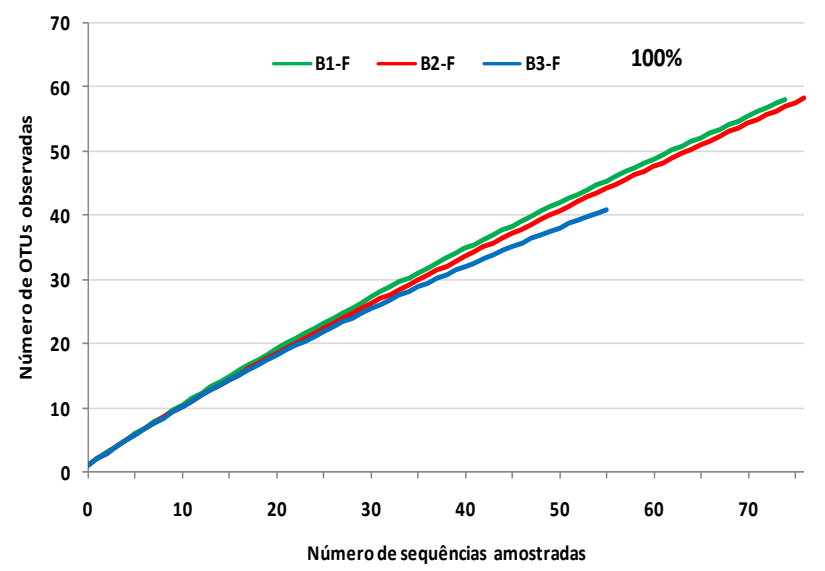

C

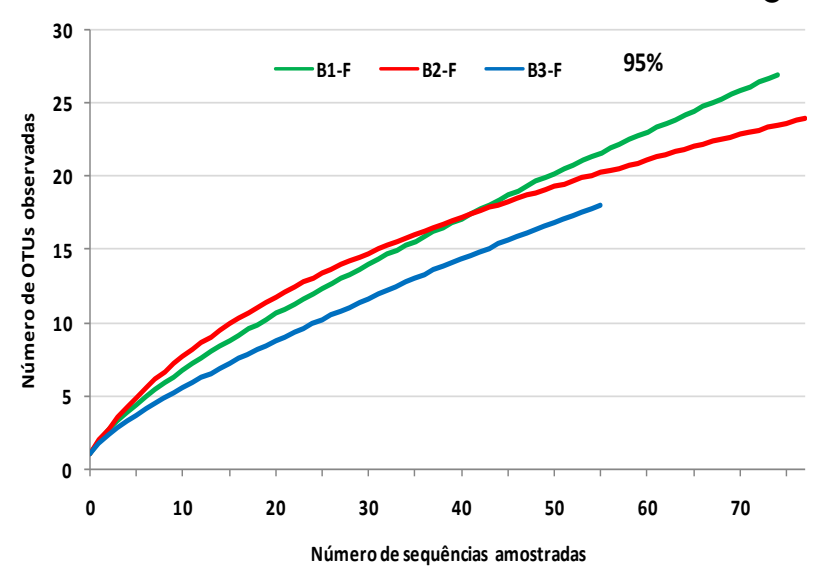

B

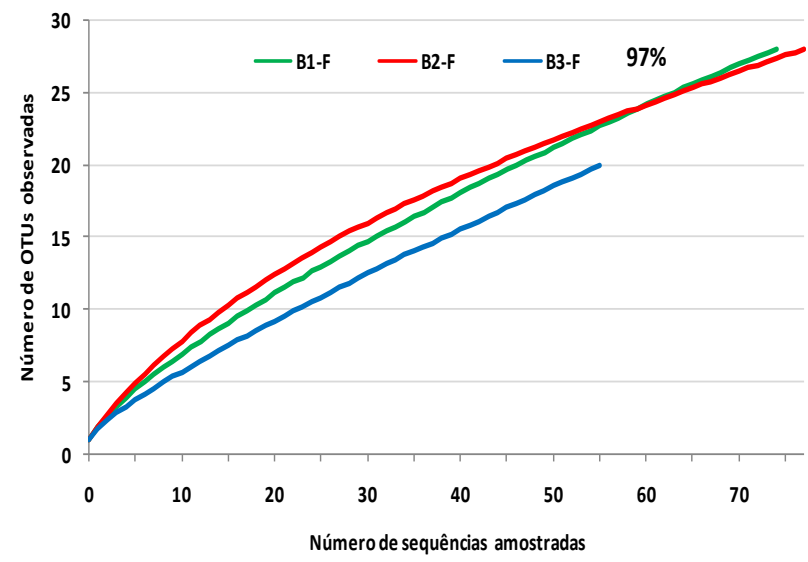

D

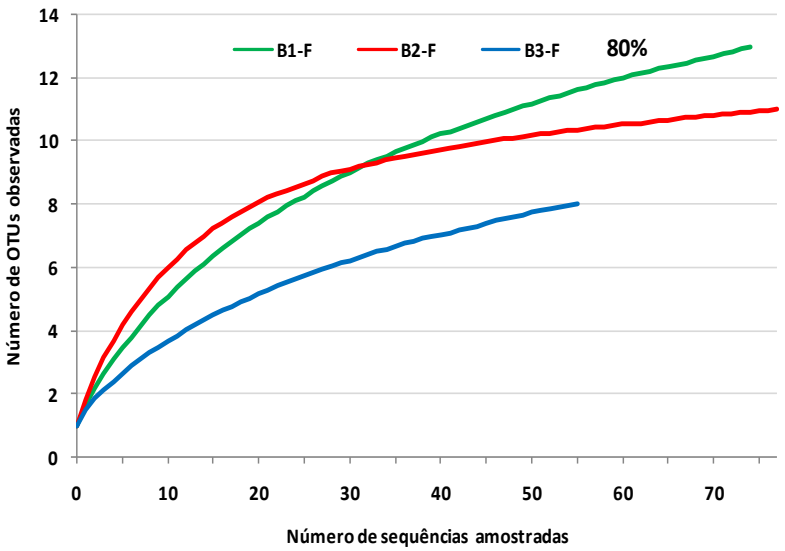

Figura 39 - Análise de rarefação dos clones constituídos pelas seqüências forward das três bibliotecas construídas a partir do DNA de amostras de água do mar do Canal de São Sebastião em cada nível de similaridade taxonômica. As análises são baseadas em seqüências parciais do gene 16S rDNA. A: nível de similaridade (100\%); B: nível de similaridade (97\%); C: nível de similaridade (95\%); D: nível de similaridade (80\%). O intervalo de confiança foi de $95 \%$.

As sequiências reverse dos clones também foram analisadas quanto às curvas de rarefação, embora apenas para obter uma comparação com as outras seqüências analisadas, visto que 21, 15 e 38 seqüências composta em cada biblioteca são insuficientes para avaliar a diversidade. Diante disso, deve-se relembrar que o número de OTUs para a biblioteca 1 não pôde ser definido usando o cutoff de $95 \%$. No entanto, o resultado dessas análises apresentou curvas com o mesmo perfil que as análises para as sequiências forward das três bibliotecas (Figura 40 A-D). 
A

B
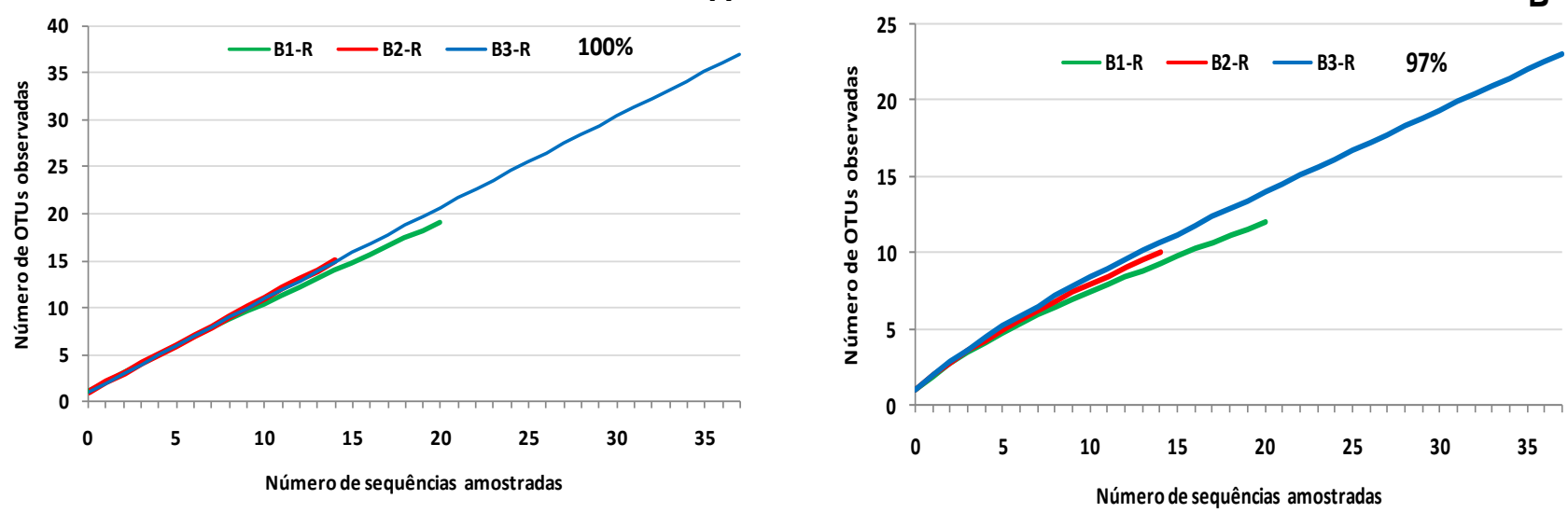

C

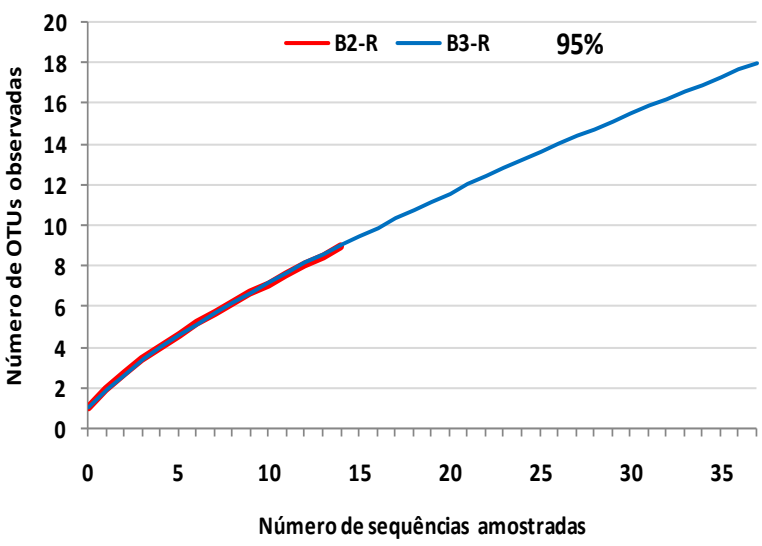

D

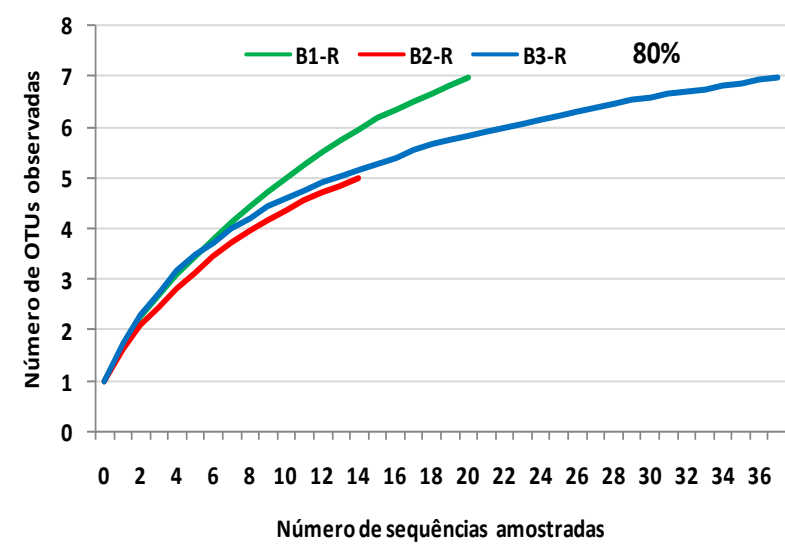

Figura 40 - Análise de rarefação dos clones constituídos pelas seqüências reverse das três bibliotecas construídas a partir do DNA de amostras de água do mar do Canal de São Sebastião em cada nível de similaridade taxonômica. As análises são baseadas em seqüências parciais do gene 16S rDNA. A: nível de similaridade (100\%); B: nível de similaridade (97\%); C: nível de similaridade (95\%); D: nível de similaridade (80\%). O intervalo de confiança foi de $95 \%$.

A tabela 10 apresenta os dados dos índices de diversidade (Shannon $-H^{\prime}$ ) e estimativa de riqueza (ACE e Chao1), considerando-se a faixa evolutiva de 97\% de similaridade para definição das OTUs. Considerando apenas as 209 seqüências forward, pôde-se notar que os índices de diversidade apresentaram valores muito próximos no cutoff de $95 \%$, principalmente entre as bibliotecas 1 e $2\left(H^{\prime}=2,48\right.$ e $H^{\prime}=2,66$, respectivamente), já que essas continham os maiores números se seqüências. 
Tabela 10 - Índices de diversidade e riqueza obtidos a partir da análise das sequiências parciais do gene 16S rDNA dos clones das três bibliotecas de amostras de água do mar do Canal de São Sebastião.

\begin{tabular}{|c|c|c|c|c|c|c|c|c|c|c|}
\hline \multirow{2}{*}{ Índices } & \multirow{2}{*}{ Biblioteca } & \multicolumn{4}{|c|}{ Similaridade considerada } & \multirow{2}{*}{ Biblioteca } & \multicolumn{4}{|c|}{ Similaridade considerada } \\
\hline & & $100 \%$ & $97 \%$ & $95 \%$ & $80 \%$ & & $100 \%$ & $97 \%$ & $95 \%$ & $80 \%$ \\
\hline \multirow{3}{*}{$\begin{array}{c}\text { Diversidade } \\
\text { (Shannon) }\end{array}$} & B1-F & $\begin{array}{c}3,92 \\
( \pm 0,27)^{*}\end{array}$ & $\begin{array}{c}2,54 \\
( \pm 0,45)\end{array}$ & $\begin{array}{c}2,48 \\
( \pm 0,45)\end{array}$ & $\begin{array}{c}1,73 \\
( \pm 0,42)\end{array}$ & B1-R & $\begin{array}{c}2,89 \\
( \pm 0,47)\end{array}$ & $\begin{array}{c}2,21 \\
( \pm 0,56)\end{array}$ & -- & $\begin{array}{c}1,50 \\
( \pm 0,62)\end{array}$ \\
\hline & B2-F & $\begin{array}{c}3,87 \\
( \pm 0,31)\end{array}$ & $\begin{array}{c}2,77 \\
( \pm 0,37)\end{array}$ & $\begin{array}{c}2,66 \\
( \pm 0,35)\end{array}$ & $\begin{array}{c}2,03 \\
( \pm 0,27)\end{array}$ & B2-R & $\begin{array}{c}2,71 \\
( \pm 0,51)\end{array}$ & $\begin{array}{c}2,12 \\
( \pm 0,62)\end{array}$ & $\begin{array}{c}1,97 \\
( \pm 0,63)\end{array}$ & $\begin{array}{c}1,20 \\
( \pm 0,69)\end{array}$ \\
\hline & B3-F & $\begin{array}{c}3,58 \\
( \pm 0,31)\end{array}$ & $\begin{array}{c}2,03 \\
( \pm 0,56)\end{array}$ & $\begin{array}{c}1,93 \\
( \pm 0,54)\end{array}$ & $\begin{array}{c}1,14 \\
( \pm 0,46)\end{array}$ & B3-R & $\begin{array}{c}3,60 \\
( \pm 0,32)\end{array}$ & $\begin{array}{c}2,78 \\
( \pm 0,48)\end{array}$ & $\begin{array}{c}2,37 \\
( \pm 0,54)\end{array}$ & $\begin{array}{c}1,53 \\
( \pm 0,39)\end{array}$ \\
\hline \multirow{3}{*}{$\begin{array}{l}\text { Riqueza } \\
\text { (Chao1) }\end{array}$} & B1-F & $\begin{array}{c}293 \\
(152-649)\end{array}$ & $\begin{array}{c}76 \\
(43-179)\end{array}$ & $\begin{array}{c}75 \\
(42-178)\end{array}$ & $\begin{array}{c}18 \\
(14-45)\end{array}$ & B1-R & $\begin{array}{c}172 \\
(81-396)\end{array}$ & $\begin{array}{c}30 \\
(16-93)\end{array}$ & -- & $\begin{array}{c}8 \\
(7-18)\end{array}$ \\
\hline & B2-F & $\begin{array}{c}272 \\
(147-572)\end{array}$ & $\begin{array}{c}62 \\
(38-142)\end{array}$ & $\begin{array}{c}41 \\
(28-88)\end{array}$ & $\begin{array}{c}12 \\
(11-19)\end{array}$ & B2-R & $\begin{array}{c}120 \\
(54-296)\end{array}$ & $\begin{array}{c}38 \\
(17-115)\end{array}$ & $\begin{array}{c}30 \\
(14-95)\end{array}$ & $\begin{array}{c}5 \\
(5-11)\end{array}$ \\
\hline & B3-F & $\begin{array}{c}93 \\
(61-172)\end{array}$ & $\begin{array}{c}60 \\
(31-161)\end{array}$ & $\begin{array}{c}38 \\
(23-91)\end{array}$ & $\begin{array}{c}9 \\
(8-19)\end{array}$ & B3-R & $\begin{array}{c}352 \\
(142-980)\end{array}$ & $\begin{array}{c}231 \\
(104-471)\end{array}$ & $\begin{array}{c}38 \\
(23-91)\end{array}$ & $\begin{array}{c}8 \\
(7-15)\end{array}$ \\
\hline \multirow{3}{*}{$\begin{array}{c}\text { Riqueza } \\
\text { (ACE) }\end{array}$} & B1-F & $\begin{array}{c}290 \\
(157-604)\end{array}$ & $\begin{array}{c}78 \\
(45-179)\end{array}$ & $\begin{array}{c}122 \\
(58-315)\end{array}$ & $\begin{array}{c}18 \\
(14-36)\end{array}$ & B1-R & $\begin{array}{c}246 \\
(58-1352)\end{array}$ & $\begin{array}{c}38 \\
(18-128)\end{array}$ & -- & $\begin{array}{c}10 \\
(8-13)\end{array}$ \\
\hline & B2-F & $\begin{array}{c}475 \\
(236-1036)\end{array}$ & $\begin{array}{c}60 \\
(39-117)\end{array}$ & $\begin{array}{c}40 \\
(29-73)\end{array}$ & $\begin{array}{c}12 \\
(11-19)\end{array}$ & B2-R & 0 & $\begin{array}{c}36 \\
(15-144)\end{array}$ & $\begin{array}{c}29 \\
(13-119)\end{array}$ & $\begin{array}{c}8 \\
(5-29)\end{array}$ \\
\hline & B3-F & $\begin{array}{c}130 \\
(75-272)\end{array}$ & $\begin{array}{c}149 \\
(75-495)\end{array}$ & $\begin{array}{c}88 \\
(38-257)\end{array}$ & $\begin{array}{c}11 \\
(8-27)\end{array}$ & B3-R & $\begin{array}{c}703 \\
(535-2696)\end{array}$ & $\begin{array}{c}140 \\
(55-450)\end{array}$ & $\begin{array}{c}67 \\
(32-190)\end{array}$ & $\begin{array}{c}9 \\
(7-21)\end{array}$ \\
\hline
\end{tabular}

*Os valores entre parênteses indicam o limite de confiança de $95 \%$.

Já considerando o índice de diversidade das seqüências reverse das três bibliotecas, considerando o mesmo cutoff (97\%), pôde-se verificar que o índice da biblioteca 3 foi maior $\left(H^{\prime}=2,78\right)$, enquanto que os índices das bibliotecas 1 e 2 continuaram sendo similares.

Analisando os dados dos índices de estimativa de riqueza foi possível observar o número de seqüências necessárias para estimar a riqueza bacteriana do Canal de São Sebastião e também verificar que o número de OTUs com sequiências forward na biblioteca 1 $(\mathrm{n}=28)$, na biblioteca $2(\mathrm{n}=28)$ e na biblioteca $3(\mathrm{n}=19)$ representou apenas $37,3 \%$ das 75 seqüências analisadas, 35,9\% das 78 sequiências analisadas e 33,9\% das 56 seqüências analisadas, respectivamente.

Para as OTUs verificadas com as seqüências reserve, os valores representados para a biblioteca $1(\mathrm{n}=12)$ foi de 57,1\%, para a biblioteca $2(\mathrm{n}=10)$ foi de $66,6 \%$ e para a biblioteca $3(n=22)$ foi de 57,9\%. Desta maneira, foi possível verificar que os números de clones amostrados não foram suficientes para representar a riqueza bacteriana no Canal de 
São Sebastião, ainda mais se tratando de dois tipos de sequiências (forward e reverse), onde a distribuição dessas seqüências em cada OTUs pode ter sido prejudicada (Figura 41).

A

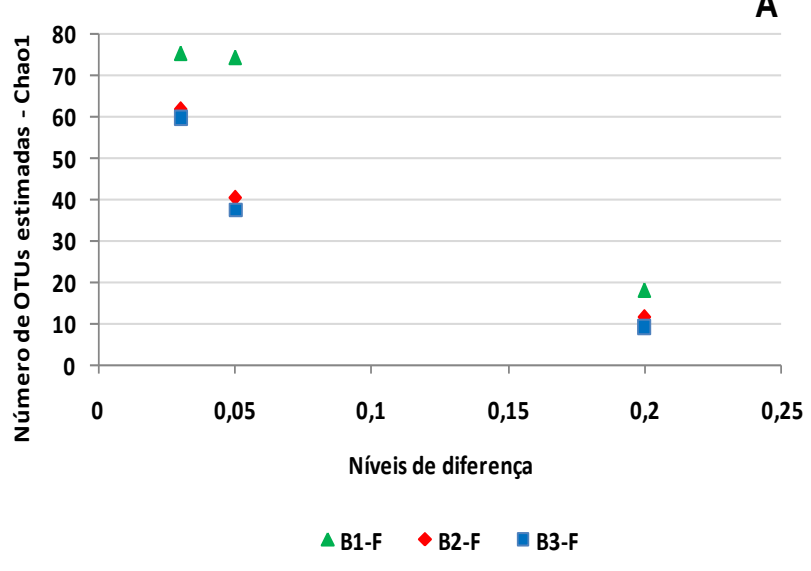

C

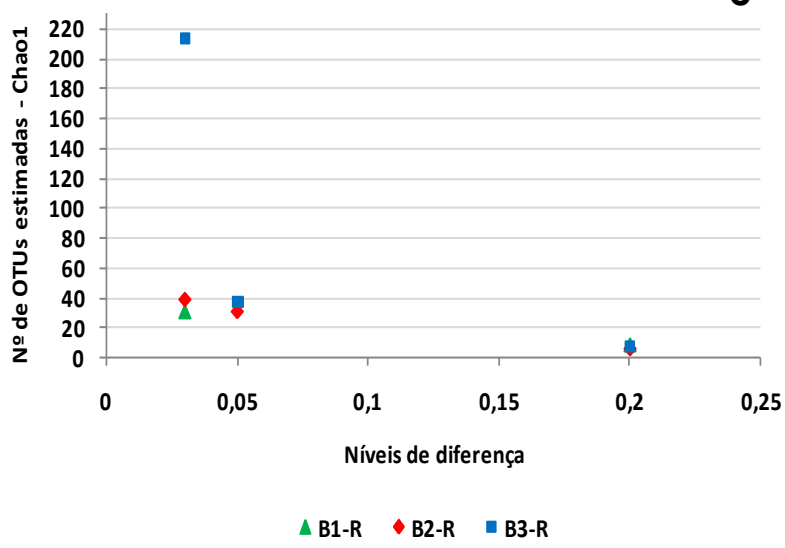

B

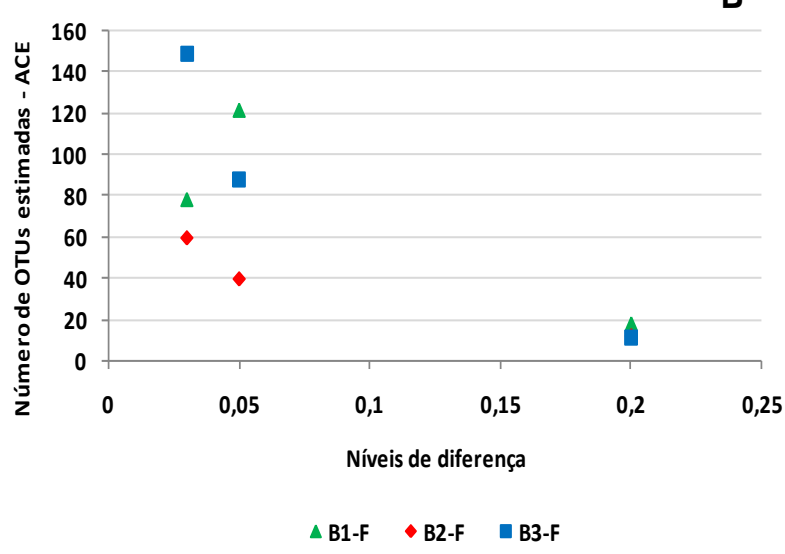

D

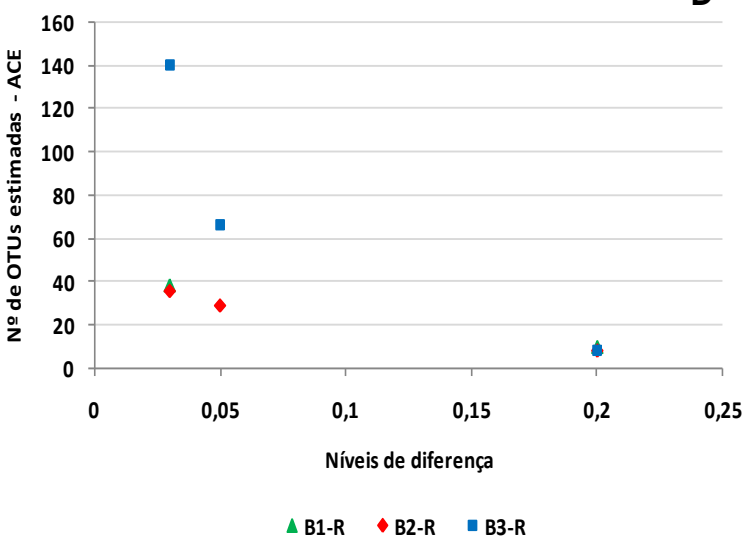

Figura 41 - Número de OTUs estimadas para cada biblioteca para as diferentes distâncias evolutivas em amostra de água do mar do Canal de São Sebastião. A: estimativa para as três bibliotecas (sequiências forward) utilizando o estimador Chao1; B: estimativa para as três bibliotecas (sequiências forward) utilizando o estimador ACE; C: estimativa para as três bibliotecas (seqüências reverse) utilizando o estimador Chao1; D: estimativa para as três bibliotecas (seqüências reverse) utilizando o estimador ACE. O intervalo de confiança foi de $95 \%$.

Levando-se em consideração o motivo pelo qual essas três bibliotecas foram construídas, "conhecer a comunidade bacteriana local e avaliar se a mesma era constante ou se mudava mensalmente", foi possível verificar que maior parte da população bacteriana esteve presente em todos os meses analisados (Novembro/2006, Fevereiro/2006 e Fevereiro/2007). No entanto, cada biblioteca apresentou filos que foram exclusivos de cada uma, mesmo as bibliotecas 2 e 3 estarem representando o mesmo mês (Fevereiro/2006 e Fevereiro/2007, respectivamente), porém em anos diferentes. 


\section{DISCUSSÃO}

\subsection{CARACTERIZAÇÃO FÍSICO-QUÍMICA DO CANAL DE SÃO SEBASTIÃo}

A água do mar do Canal de São Sebastião possui características termohalinas que são determinadas pela mistura das massas de Água Costeira (AC), Água Tropical (AT), Água Central do Atlântico Sul (ACAS), além do padrão das correntes geradas, principalmente, pelo vento e das condições climatológicas prevalecentes na região (AIDAR et al., 1993; CASTRO FILHO et al., 1987; CASTRO FILHO, 1990). Essas massas de água superficiais podem influenciar os valores de temperatura e salinidade, visto que suas características estão relacionadas com a radiação solar, temperatura do ar e índice pluviométrico da região.

No presente estudo foram registradas variações de temperaturas da água do mar $(21,5$ a $26,3{ }^{\circ} \mathrm{C}$ ) equivalentes a outros trabalhos feitos no mesmo local. Num estudo sobre a climatologia das águas do Canal de São Sebastião, Leandro (1999) observou temperaturas médias entre $20,7-27{ }^{\circ} \mathrm{C}$ considerando as quatro estações do ano. Resultados similares (20 a $25{ }^{\circ} \mathrm{C}$ ) foram observados no estudo da circulação termohalina do Canal, levando-se em consideração os mesmos períodos amostrais (SILVA, 2001). Já num estudo mais recente foi mostrado temperaturas pouco acima das mencionadas $\left(22,5\right.$ a $\left.27,5^{\circ} \mathrm{C}\right)$ nos períodos de abril e novembro de 2004, mas ainda dentro do padrão obtido no Canal de São Sebastião (VENTURINI, 2007).

A salinidade variou entre 34 e 35\% no Canal de São Sebastião durante os 20 meses amostrados. Embora a salinidade da água do mar já seja conhecida (35\%), a mesma concentração não é mantida em todos os ambientes marinhos ao redor do globo. Dessa maneira, a variação de salinidade encontrada neste estudo também já foi verificada em outras pesquisas feitas no Canal de São Sebastião (COELHO, 1997; SILVA, 2001; VENTURINI, 2007). Esse parâmetro pode estar diretamente relacionado com as direções do vento que, por sua vez, interferem nas correntes marítimas que podem trazer águas mais salinas para a superfície. Como estes dois parâmetros podem ser influenciados pelas massas de água (AC, AT, ACAS) e diante da variação observada em seus valores, pode-se sugerir que a massa de AC (> $20^{\circ} \mathrm{C}$ e 32,2-35,4\%o) pode ter estado presente nas camadas superficiais das águas do Canal de São Sebastião neste período amostrado, assim também como a radiação solar e a temperatura do ar podem estar relacionadas com esses resultados. 
Embora a condutividade da água do mar esteja relacionada com a temperatura e a salinidade, a variação mínima e máxima desse parâmetro (37,6 e 49,4 mS) não foi relacionada com os menores e maiores valores verificados para esses outros dois parâmetros mencionados.

Para o pH, o valor médio $(8,3)$ verificado, além de estar dentro de uma faixa normalmente encontrada entre águas salinas, ainda está dentro dos padrões das norma recomendada pela Resolução Federal do Conselho Nacional do Meio Ambiente (CONAMA) $\mathrm{n}^{\circ} 357 / 2005(6,5$ - 8,5). Da mesma maneira, as concentrações de oxigênio dissolvido se apresentaram próximos aos estabelecidos nessa mesma norma (não inferior a $5 \mathrm{mg} / \mathrm{L} \mathrm{O}_{2}$ ).

\subsection{CARACTERIZAÇÃo MICROBIOLÓGICA DAS AMOSTRAS DE ÁGUA DO MAR}

\subsubsection{Contagem e isolamento de bactérias marinhas}

Vários estudos já vêm sendo feitos para caracterizar e quantificar as bactérias heterotróficas em oceanos e em diferentes áreas de climas temperados, tropicais e zonas polares (BILLEN et al., 1990; DUCKLOW et al., 1993; HOPKINSON et al., 1998; DU et al., 2006; GONZALEZ et al., 2006). A razão para isso é que as bactérias heterotróficas dominam a assimilação de matéria orgânica dissolvida nos oceanos mesmo que esta possa ser usada por outros organismos (cianobactérias, fitoplâncton, protistas e eucariotos) (MULHOLLAND et $a l .$, 2002). Embora as bactérias sejam os menores microrganismos, elas têm a maior razão área/volume da superfície comparadas a todos os microrganismos tornando-se dominantes na assimilação dos compostos dissolvidos (KIRCHMAN, 2008).

Sabe-se que a concentração bacteriana na coluna d'água vai decrescendo com a profundidade e aumenta no fundo do oceano. Esse fato pode ser explicado pelas águas da superfície marinha apresentarem um grande número de organismos que representam um bom substrato nutricional para as bactérias heterotróficas, favorecendo assim, o crescimento bacteriano. Por outro lado, apesar da diminuição da luminosidade e temperatura à medida que aumenta a profundidade, é evidente que uma mínima circulação hidrodinâmica permite que matérias orgânicas se depositem no fundo, explicando a alta concentração bacteriana em sedimentos marinhos (BIANCHI, 1980; CAVALLO et al., 1999). 
O meio de cultura (Ágar Marinho) utilizado neste estudo para quantificar e isolar as bactérias marinhas já havia sido testado quanto à sua eficiência quando comparado com o Ágar Plate Count durante o desenvolvimento do projeto "Diagnóstico Microbiológico de áreas de risco em portos brasileiros" desenvolvido em colaboração com ANVISA, em 2004. O meio Ágar Marinho foi o que apresentou melhor resultado para o crescimento de bactérias sendo, portanto, utilizado neste trabalho. Desde 1941 este meio de cultura tem sido aplicado em estudos que envolvem enumeração de bactérias heterotróficas marinhas (ZOBELL, 1941; AUSTIN et al., 1979; SCHUT et al., 1993; DU et al. 2006).

A concentração de bactérias marinhas obtidas neste estudo pela contagem em placa mostrou uma variação de duas ordens de magnitudes $\left(10^{1}\right.$ a $\left.10^{3} \mathrm{UFC} / \mathrm{mL}\right)$, onde as maiores e menores concentrações puderam ser verificadas nos meses de fevereiro/2006 e dezembro/2006, respectivamente. É valido destacar que essas variações nas concentrações de bactérias marinhas foram relacionadas às concentrações de coliformes termotolerantes e enterococos intestinais, de acordo com as análises estatísticas realizadas neste trabalho.

A similaridade entre as concentrações de bactérias marinhas em ambos os pontos de coleta podem ser explicadas pela localização dos pontos amostrados, que apesar de um deles (P2) ser um pouco mais afastado da costa, ainda são relativamente pertos um do outro. Além disso, a Ilha de São Sebastião (município de Ilhabela) funciona como barreira natural às ondas do mar aberto e aos ventos carregados de umidade provenientes do oceano rumo ao continente, provocando assim um efeito bastante interessante de canalização dos ventos na direção do canal.

Um dos primeiros estudos físicos realizados na região (EMILSSON, 1962) mostrou que as correntes marítimas na região são altamente influenciadas pelos ventos, os quais quando vindo do Sul levam as correntes em direção ao norte, enquanto que ventos vindos do norte forçam-na em direção oposta. Dessa maneira, a proximidade de um ponto ao outro também pode fazer com que os mesmos sofram essas mesmas influências o que explica a semelhança nas concentrações bacterianas em ambos os pontos.

Fatores climáticos (corrente marítima sul e céu nublado) podem ter influenciado nas flutuações de bactérias marinhas no Canal de São Sebastião, conforme mostrados pelas análises estatísticas, onde as maiores concentrações foram verificadas nessas condições, ou seja, quando a corrente marítima vinda do sul estava presente e quando a coleta foi feita em dias em que o céu estava nublado. Embora o período amostral desse estudo tenha compreendido épocas com estações do ano diferentes, as variações nas concentrações 
bacterianas não demonstraram ter influência sazonal, principalmente no que diz respeito à temperatura da água do mar.

Por outro lado, trabalhos vêm mostrando que as flutuações sazonais de bactérias marinhas são constatadas no ambiente marinho (SEKI, 1966; CAVALLO et al., 1999; GONZALES-ACOSTA, 2006). Mas deve-se levar em consideração que as variações sazonais nas concentrações bacterianas foram encontradas em países que possuem climas diferentes do Brasil, como Japão, Itália e México, onde as quatro estações do ano são bem definidas.

Levando em consideração a concentração das bactérias marinhas, foi possível verificar que os valores obtidos no presente estudo $\left(10^{1}\right.$ a $\left.10^{3}\right)$ foram similares aos valores encontrados em outro trabalho feito pelo laboratório de Microbiologia Ambiental (ICB/USP) em parceria com a Agência Nacional de Vigilância Sanitária - ANVISA (2004) na costa onde estão localizados sete portos brasileiros.

Nesses portos foram constatadas variações de $1,5 \times 10^{1}$ a 5,6 x $10^{4} \mathrm{UFC} / \mathrm{mL}$, visto que o menor valor foi verificado no porto de Sepetiba, RJ, o qual está em uma área de preservação ambiental e com pouca atividade antropogênica e o maior valor $\left(5,6 \times 10^{4} \mathrm{UFC} / \mathrm{mL}\right)$ foi verificado no porto de Santos, SP, o maior porto brasileiro e o que possui o maior movimento de navios. Além disso, esta região possui grande influência de descarga de água de lastro de navios, barracas de comercialização, indústrias de pescado e de diversas atividades antropogênicas.

Desta forma, estes dados também comprovam que as concentrações e distribuição de bactérias marinhas estão diretamente relacionadas com as atividades antropogênicas que, conseqüentemente, aumentam o índice de contaminação em uma área, mostrando assim que essas bactérias podem ser usadas como indicadoras de poluição.

No estudo da composição da comunidade bacteriana presente na coluna d'água na Baía de Chesapeake, Estados Unidos $\left(2,0 \times 10^{4} \mathrm{UFC} / \mathrm{mL}\right)$ e na Baía de Tokyo, Japão $(9,1 \mathrm{x}$ $10^{4} \mathrm{UFC} / \mathrm{mL}$ ) também foi mostrado que, apesar da extrema distância geográfica entre essas duas áreas, a concentração bacteriana foi similar quando utilizada a contagem em placa e o meio Ágar Marinho (AUSTIN et al., 1979).

Utilizando o mesmo meio, Bernard et al. (2000) puderam quantificar $1,3 \times 10^{4}$ cél/mL de células bacterianas cultivadas nas amostras de água coletadas no mar Mediterrâneo. Assim também, nas águas do mar Piccolo, na Itália, variações na mesma ordem de magnitude foram observadas $\left(2,9 \times 10^{4}\right.$ a 1,7 x $\left.10^{5} \mathrm{UFC} / \mathrm{mL}\right)$ (CAVALLO et al., 1999). 
Dessa forma, foi possível comparar os resultados de concentração de bactérias marinhas cultivadas quantificadas nesse estudo com dados obtidos em outras áreas geográficas utilizando a mesma metodologia de enumeração.

\subsubsection{Caracterização fenotípica das bactérias marinhas}

Originalmente, foi estimado que 95\% das bactérias marinhas eram Gram-negativas e que, apenas, 5\% das bactérias presentes no oceano são Gram-positivas (ZOBELL, 1946). Posteriormente, estudos demonstraram que as bactérias marinhas cultiváveis são predominantemente gram-negativas (GOSINK et al., 1998; STALEY e GOSINK, 1999; ZACCONE et al., 2002; DAS et al., 2006), embora tenha sido comprovado que as bactérias gram-positivas também venha sendo verificada, mas com maior abundância em sedimento marinho (PRIEST, 1989; STACH e BULL, 2005; JENSEN et al., 2005; GONTANG et al., 2007).

De acordo com o relatado, os resultados encontrados nesse estudo corroboram com os encontrados na literatura, visto que a porcentagem de bactérias gram-negativas $(86,4 \%)$ foi significantemente maior comparada com as gram-positivas. Estes resultados puderam ser confirmados nas duas técnicas empregadas (coloração de gram e teste de $\mathrm{KOH}$ ). Por outro lado, houve uma diferença de 3,6\% entre os resultados de uma técnica e outra, mas de acordo com Buck (1982) o teste de $\mathrm{KOH}$ pode gerar uma diferença de até 8\% quando comparado com os resultados de coloração de Gram, já que este método não detecta as bactérias gramvariáveis.

\subsubsection{Qualidade microbiológica das amostras de água do mar}

O elevado crescimento populacional nos municípios do litoral brasileiro e a população flutuante, principalmente nos meses de férias de verão e nos finais de semana, podem influenciar na qualidade das águas costeiras. A qualidade dessas águas é consequiência direta ou indireta das medidas de infra-estrutura sanitária adotadas no país e a principal dificuldade do monitoramento da qualidade da água é o estabelecimento de indicadores adequados e a definição dos critérios a serem adotados para a avaliação da balneabilidade (CETESB, 2008).

A legislação ambiental relacionada à qualidade das águas litorâneas é regulada, principalmente, pela Resolução do CONAMA $n^{\circ}$ 274/2000. Segundo os critérios 
estabelecidos nesta Resolução, densidades de Coliformes Termotolerantes, Escherichia coli e Enterococos Intestinais superiores a $1000 \mathrm{UFC} / 100 \mathrm{~mL}, 800 \mathrm{UFC} / 100 \mathrm{~mL}$ e $100 \mathrm{UFC} / 100$ $\mathrm{mL}$, respectivamente, em duas ou mais amostras de um conjunto de cinco semanas, caracterizam a impropriedade de uma praia para recreação de contato primário (balneabilidade). Apesar das coletas de amostras nesse trabalho não terem sido feitas semanalmente e sim mensalmente, os resultados das amostras foram avaliados como indicativas de contaminação pontual.

As amostras de água coletadas no Canal de São Sebastião apresentaram contagens de Coliformes Termotolerantes e Enterococos Intestinais abaixo dos valores estabelecidos pela Resolução CONAMA n ${ }^{\circ}$ 274/2000, mostrando assim que o nível de impacto antropogênico é baixo nesse local, o que é confirmado, ao comparar os resultados obtidos nesse trabalho, com dados de balneabilidade da CETESB que mostrou que as praias próximas aos nossos pontos de coleta permaneceram próprias para atividades de recreação primária durante todo o ano de 2006 e 2007 (CETESB, 2008).

Dessa forma, com os resultados aqui mostrados e, de acordo com os obtidos por ROSERO-BURBANO (2009), pôde-se classificar o Canal de São Sebastião como um ambiente de médio impacto antropogênico, em relação às contagens dos indicadores de poluição fecal.

\subsection{CARACTERIZAÇÃO MOLECULAR DOS ISOLADOS DE BACTÉRIAS MARINHAS}

\subsubsection{Tipagem molecular utilizando os métodos BOX-PCR e ERIC-PCR}

Os métodos de fingerprinting rep-PCR (BOX-PCR, ERIC-PCR e REP-PCR) gerados de isolados bacterianos permite a diferenciação de bactérias para as espécies e subespécies e pode representar o método de fingerprinting genômico mais discriminatório e reprodutivo disponível para uma análise de múltiplas amostras (LOUWS et al., 1996; RADEMAKER e de BRUIJN, 1997; VERSALOVIC et al., 1998).

As técnicas de tipagem (BOX-PCR e ERIC-PCR) empregadas utilizam iniciadores que correspondem a regiões intercaladas repetitivas presentes em locais específicos do genoma procariótico e geram um fingerprinting altamente específico e reprodutível (LUPSKI e WEINSTOCK, 1992; VERSALOVIC et al., 1998). 
Apesar de já estarem bem descritos e já terem sido aplicados em diversas análises, estes métodos são utilizados, especialmente, para analisar a diversidade e taxonomia de várias espécies bacterianas, mas especialmente é empregado na diferenciação de cepas bacterianas dentro de uma mesma espécie (LOUWS et al., 1996; RADEMAKER et al., 2004b). Em contraste, um estudo utilizando a técnica de BOX-PCR para caracterizar isolados bacterianos de amostras ambientais foi encontrado (FREITAS et al., 2008), haja vista que a aplicação desses métodos em análises de diversidade de bactérias ambientais é rara.

O intuito de caracterizar estes isolados bacterianos por tipagem molecular através destas duas técnicas de fingerprinting foi evidenciar a freqüência de perfis comuns nas amostras coletadas mensalmente e, assim, diminuir o número de bactérias marinhas a serem seqüenciadas, uma vez que estas técnicas oferecem a vantagem da rapidez, praticidade e baixo custo. No entanto, os perfis gerados por estes fingerprintings foram bem diversificados, não sendo possível utilizar os resultados obtidos por essas técnicas como critério de seleção para as bactérias a serem identificadas pelo seqüenciamento do gene $16 \mathrm{~S}$ rDNA.

No que diz respeito aos resultados obtidos em ambas as técnicas (BOX-PCR e ERICPCR), pôde ser verificado que o perfil genético das bactérias marinhas foi diferente, assim como a sensibilidade das técnicas. A técnica de BOX-PCR mostrou, sem dúvida, ser mais eficaz entre as bactérias marinhas, no que se refere ao número de amplificações $(90,4 \%)$, uma vez que com a utilização da técnica de ERIC-PCR somente 45,4\% das mesmas bactérias apresentaram resultados positivos (amplificação).

Os resultados aqui obtidos puderam ser comparados com outros trabalhos realizados utilizando as mesmas técnicas de tipagem que obtiveram resultados semelhantes, onde a técnica de BOX-PCR apresentou um maior poder discriminatório, em relação à de ERIC-PCR (SOUZA, 2007; MARKMAN, 2008). Por outro lado, esses autores aplicaram essas técnicas para caracterização de isolados do gênero Vibrio em amostras de água do mar e de lastro.

Em contrapartida, os produtos de amplificação obtidos com a técnica de ERIC-PCR, das poucas bactérias marinhas amplificadas, apresentaram perfis genéticos com o maior número de bandas ( 2 a 11 bandas), enquanto que no BOX-PCR a maior frequiência de bandas variou de 2 a 5 . Essa diferença no número de bandas entre uma técnica e outra também foi verificada por Ming et al. (2008) no estudo conduzido na China para avaliar a diversidade bacteriana através de técnicas de rep-PCR.

Estas técnicas de rep-PCR têm sido amplamente utilizadas em estudos de diversidade genética bacterianas, mostrando uma alta resolução na classificação de bactérias em nível de 
espécies, subespécies ou linhagens (RADEMAKER e de BRUIJN, 1997; GORIS et al., 2003; YANG et al., 2004). Mas é importante destacar que esse alto poder discriminatório apresentado por essas técnicas é apresentado quando linhagens ou espécies de microrganismos do mesmo grupo são utilizadas.

As técnicas de rep-PCR já mostraram ser úteis na análise da diversidade genética entre cepas bacterianas (SAWABE et al., 2002), mas além dessas, outra técnica de fingerprinting denominada AFLP (Amplified Fragment Length Polymorphism) tem sido usada na taxonomia bacteriana e já provou ser uma poderosa ferramenta para discriminar espécies e cepas de Vibrio (HUYS et al., 1996; JANSSEN et al., 1996; THOMPSON et al., 2001; THOMPSON et al., 2004).

A técnica de AFLP tem um maior poder discriminatório que as técnicas de rep-PCR (RADEMAKER et al., 2000). No entanto, os resultados dessas duas técnicas de análises estão muito próximos com os obtidos em estudos de hibridização DNA-DNA, tornando-as importantes ferramentas para a determinação das estruturas taxonômicas e filogenéticas das populações bacterianas (NICK et al., 1999; DUIM et al.; 2001).

No entanto, diferente do proposto nesse estudo, mais uma vez cabe mencionar, que estas técnicas são úteis quando o objetivo do estudo é analisar a diversidade entre diferentes linhagens bacterianas conhecidas, fato que pode justificar a falta de sensibilidade das técnicas de rep-PCR quando aplicadas neste trabalho, visto que os isolados bacterianos analisados foram muito diversos.

\subsubsection{Seqüenciamento parcial da região $16 \mathrm{~S}$ rRNA dos isolados bacterianos}

Uma tecnologia utilizada para esta análise, relativamente rápida e barata, altamente reprodutível e de fácil acesso a qualquer grupo de pesquisa, é o seqüenciamento de DNA. Os bancos de dados de sequiências de genes e os programas computacionais empregados são gratuitos. Por esta razão, a análise de seqüências de DNA vem sendo cada vez mais aplicada em estudos taxonômicos (ZEIGLER, 2003).

No caso da identificação bacteriana, o seqüenciamento do gene 16S rDNA tem sido utilizado como parte integrante no que diz respeito à taxonomia bacteriana, muito embora este gene não seja útil para identificar muitas bactérias ao nível de espécie (BUCKLEY e ROBERTS, 2006). Diante disso, as bactérias marinhas estudadas neste trabalho foram identificadas, quanto ao gênero, através do seqüenciamento parcial da região $16 \mathrm{~S}$ rRNA. 
Um resultado relevante foi observado neste estudo, no que se refere à distribuição e freqüência dessas bactérias dentro dos gêneros identificados. A maior freqüência $(86,9 \%)$ dessas bactérias foi identificada como pertencentes ao gênero Vibrio. É sabido que o gênero Vibrio é altamente abundante em ambientes aquáticos, incluindo estuários, águas e sedimentos marinhos e também áreas de cultivo (GRIMES et al., 1984; ORTIGOSA et al., 1989; REHNSTAM et al., 1993; BARBIERI et al., 1999; URAKAWA et al., 2000; HEIDELBERG et al., 2002) e talvez se deva a isso o fato da maioria das bactérias marinhas terem sido identificadas como Vibrio sp.

De todos os grupos de microrganismos estudados no ambiente marinho, os membros da família Vibrionaceae, provavelmente, constituem a maior parte das populações bacterianas heterotróficas (ORTIGOSA et al., 1994; HEIDELBERG, 1997). Esta família é composta por 8 gêneros, sendo o gênero Vibrio o maior deles, compreendendo 81 espécies descritas que são ubíquas do ambiente marinho (THOMPSON e SWINGS, 2006; THOMPSON et al., 2007).

Além disso, o meio de cultura utilizado para isolamento dessas bactérias pode ter propiciado o crescimento de bactérias pertencentes a esse gênero, visto que não é de hoje que vem sendo relatado na literatura que o meio Ágar 2216E (ZOBELL, 1941), também conhecido comercialmente como Ágar Marinho, é considerado o melhor meio para isolamento primário e quantificação de bactérias heterotróficas marinhas, incluindo os vibrios (ZOBELL e MORITA, 1957; PATRICK, 1978; SCHUT et al., 1993; THOMPSON et al., 2004; DU et al., 2006).

Bactérias pertencentes ao gênero Photobacterium também foram isoladas neste estudo, embora com freqüência bem inferior $(3,5 \%)$ as pertencentes ao gênero Vibrio. Este gênero foi descrito pela primeira vez por Beijerinck (1889) para descrever as bactérias bioluminescentes que foram isoladas de diversas fontes, principalmente do ambiente marinho (BUCHANAN et $a l . ;$ 1966; BAUMANN e BAUMANN, 1981).

Atualmente este gênero compreende 19 espécies, das quais 5 possuem cepas que produzem luminescência (YOSHIZAWA et al., 2009). Análises filogenéticas baseadas nas seqüências do gene $16 \mathrm{~S}$ rDNA tem mostrado que este gênero tem uma relação muito próxima com o gênero Vibrio, o que explica as similaridades fenotípicas entre eles (NOGI et al., 1998; ANZAI et al., 2000; FARMER III e HICKMAN-BRENNER, 2006).

A afirmação anterior pode ser comprovada no estudo de Thompson et al. (2005b) que ao analisar a taxonomia de cepas bacterianas isoladas de corais, identificou uma cepa que, fenotipicamente, tinha as características de uma espécie de Vibrio, mas através das sequiências 
dos genes $16 \mathrm{~S}$, recA e rpoA pôde comprovar que se tratava de uma nova espécie pertencente ao gênero Photobacterium ( $P$. rosenbergii).

Nos últimos anos, novas espécies de Photobacterium sp. foram descritas, como ocorreu em 2006, na Coréia do Sul onde uma cepa de bactéria halofílica foi isolada de água do mar usando o mesmo meio de cultivo empregado neste estudo e a mesma foi identificada como uma nova espécie bacteriana ( $P$. ganghwense) pertencente a esse gênero (PARK et al., 2006). Recentemente, um trabalho semelhante foi publicado na literatura, identificando outra cepa bacteriana isolada da Baía de Sagami, no Japão como uma nova espécie dentro desse gênero (P. aquimaris) (YOSHIZAWA et al., 2009).

Deve-se lembrar que estes dois gêneros que apresentaram maior freqüência entre as bactérias marinhas estudadas no presente trabalho pertencem a família Vibrionaceae que, conforme mencionado anteriormente, é o maior grupo de bactérias descritas no ambiente marinho.

O gênero Pseudomonas é comumente descrito em solos e ecossistemas aquáticos, mas ao mesmo tempo são importantes patógenos de plantas, animais e humanos (PALLERONI, 1992; SCHROTH et al., 1992). A maioria das espécies de Pseudomonas requer poucas fontes de nutrientes para seu crescimento (MOORE et al., 2006) o que pode explicar o isolamento de apenas quatro bactérias $(2,4 \%)$ pertencentes a este gênero utilizando o meio Ágar Marinho neste trabalho.

Espécies de Aeromonas são encontradas em nichos ecológicos variados, como ecossistemas aquáticos marinhos e de água doce, assim como em sedimentos (FARMER III et $a l .$, 2006). Um dos primeiros relatos da distribuição de Aeromonas em amostras de água naturais foi feita por Hazen et al. (1978), onde foi verificado que as maiores contagens desse gênero foram obtidas de habitats marinhos, mas os autores também observaram que em salinidades altas (>26\%) esta bactéria não foi detectada.

No caso, o Canal de São Sebastião possui uma salinidade superior ao mencionado pelos autores podendo ser um dos motivos pelos quais somente 1,2\% das bactérias isoladas neste trabalho foram identificadas para esse gênero. No entanto, o meio de cultura utilizado também pode ter inibido o crescimento dessas bactérias, visto que é um meio que possui quantidades elevadas de cloreto de sódio $(\mathrm{NaCl})$ e já foi verificado que utilizando meio mínimo com quitina, como única fonte de carbono, bactérias do gênero Aeromonas foram mais freqüentes (SOUZA, 2009). 
Três isolados bacterianos foram identificados para os gêneros Alteromonas e Pseudoalteromonas. Bactérias pertencentes a esses gêneros são componentes essenciais do ambiente marinho desde regiões costeiras, oceanos até fendas hidrotermais (MIKHAILOV et al., 2006). O gênero Pseudoalteromonas foi proposto em 1995, por Gauthier et al., após confirmar que o gênero Alteromonas era geneticamente heterogêneo.

O último isolado deste estudo pertencente à classe Gammaproteobacteria foi identificado como membro do gênero Shewanella, que apresentou uma similaridade de 98,8\% com a linhagem Shewanella algae (ATCC 51192). O gênero Shewanella vem sendo estudado há décadas e ao longo dos anos já foi classificada como Achromobacter, Pseudomonas, Alteromonas e Shewanella (VENKATESWARAN et al., 1999). Devido à similaridade genética com as Vibrionaceae foi recomendado que este gênero fosse reclassificado na família Vibrionaceae (MACDONELL e COLWELL, 1985). Algumas espécies marinhas podem ser patogênicas a humanos, causando septicemia, infecções de pele e ouvido (RICHARDS et al., 2008).

Entre as bactérias classificadas dentro da classe Alphaproteobacteria foram identificadas três gêneros no Canal de São Sebastião, embora em baixa freqüência: Paracoccus sp. (0,6\%), Thalassobius sp. (0,6\%) e Yangia sp. (1,8\%). O gênero Paracoccus inclui as bactérias desnitrificantes que utilizam nitrato como aceptor final de elétrons em condições anaeróbias. São comumente encontradas na água, solo e esgoto (van SPANNING et al., 2005). A primeira descrição da bactéria foi realizada em 1910 por Beijerinck e Minkman (BAJ, 2000) como Micrococcus denitrificans pela sua forma de cocos e, posteriormente, foi denominado Paracoccus denitrificans que inicialmente foi o único representante do gênero.

O gênero Thalassobius foi proposto como um novo gênero recentemente (ARAHAL et al., 2005) e até essa data possuía apenas duas espécies descritas (T. mediterraneus e T. gelatinovorus) que são exclusivamente marinhas. O único isolado que foi obtido nesse estudo apresentou 99,6\% de similaridade com a linhagem tipo T. mediterraneus.

Durante uma pesquisa ecológica em sedimentos marinhos na China, uma linhagem bacteriana foi isolada em Ágar Marinho, a qual possuía características semelhantes com algumas espécies já descritas em outros gêneros. No entanto, em 2006 foi constatado que, além desta linhagem ser classificada em um novo gênero também foi considerada como espécie nova (Yangia pacifica) (DAI et al., 2006). 
A única bactéria marinha que foi isolada da classe Betaproteobacteria foi identificada como Alcaligenes sp. Este gênero foi descrito por Castellani e Chalmer (1919), mas após inúmeras reclassificações engloba duas espécies tipo (A. faecalis com duas subespécies e $A$. defragrans) (SCHROLL et al., 2001; FOSS et al., 1998). Seu isolamento já foi verificado em diversas fontes: solo, água, fezes, urina, sangue (KERTERS e DE LEY, 1984), porém não são incomuns no ambiente marinho (ZOBELL e UPHAM, 1944; BAUMANN et al., 1972; AUSTIN et al., 1981).

\subsection{DETERMINAÇÃO DA CONCENTRAÇÃO BACTERIANA PELA TÉCNICA DE HIBRIDIZAÇÃO in situ FLUORESCENTE (FISH)}

Em estudos de microbiologia aquática, análises de imagem têm sido aplicadas para quantificar a comunidade bacteriana total (SIERACKI et al., 1985; BJORNSEN e KUPARINEN, 1991; PERNTHALER et al., 2003). Essa comunidade está sendo estudada, por métodos moleculares, através da análise direta da população do meio ambiente e os resultados têm revelado um cenário composto por uma rica diversidade de organismos ainda não-cultivados e não estudados em laboratório (WARD et al., 1990; BORNEMAN e TRIPLETT, 1997; PACE, 1997; HUGENHOLTZ et al., 1998a, b).

Técnicas de hibridização in situ (FISH) usando sondas marcadas de 16S rRNA tem sido usadas (AMANN et al., 1995). Sua aplicação na identificação filogenética, ecológica e em estudos sobre o número de comunidades ambientais tem obtido resultados favoráveis (AMANN et al., 1990; DeLONG et al., 1999; MOTER e GOBEL, 2000; AMANN et al., 2001) e isso se deve ao fato desta técnica ser rápida e sensível (ERCOLINI et al., 2003).

Com o auxílio da microscopia epifluorescente foi possível detectar a concentração de células bacterianas existentes na água do mar que é de $10^{6}$ células/mL (FERGUSON e RUBLEE, 1976; HOBBIE et al., 1977). A concentração bacteriana total verificada no presente estudo chegou à ordem de $10^{7}$ céls $/ \mathrm{mL}$. Os nossos resultados foram superiores aos encontrados numa pesquisa feita para analisar a abundância de bactérias na costa norte da Alemanha, onde a maior concentração de células verificada foi de $10^{6} / \mathrm{mL}$ (EILERS et al., 2000). Em contraste, foi similar aos obtidos no estudo realizado na Baía de Santa Mônica, Califórnia que verificou uma variação de células totais na ordem de $10^{5}$ a $10^{6} / \mathrm{mL}$ (KARNER e FUHRMAN, 1997). 
Comparando a concentração bacteriana deste estudo com outros feitos aqui no Brasil, pode-se notar que a variação constatada no presente trabalho $\left(7,0 \times 10^{6}\right.$ a $2,3 \times 10^{7}$ céls $\left./ \mathrm{mL}\right)$ foi superior ao verificado por Ribeiro (1996) que verificou que a distribuição de bactérias heterotróficas variou de 5,08 x $10^{5}$ a $3,62 \times 10^{6}$ células/mL quando coradas com DAPI. Por outro lado, os nossos resultados foram equivalentes aos encontrados por Gonzalez et al. (2006) que observou que a abundância bacteriana total variou de $8,7 \times 10^{6}$ a $1,1 \times 10^{7}$ cél $/ \mathrm{mL}$ nas praias de Ipanema e no Leblon, respectivamente. Entretanto, esses resultados foram determinados por citometria de fluxo.

Observando a média da variação dos grupos $\alpha$-, $\beta$-, $\gamma$ - e $\delta$-proteobacteria, em relação às células totais detectadas por DAPI, pôde-se verificar que o grupo predominante foi o da $\beta$ proteobacteria que representou 10,2\% das células totais, seguido dos grupos $\alpha$-proteobacteria e $\gamma$-proteobacteria, representando $9,5 \%$ e $8,1 \%$, respectivamente. Apesar da variação nessas porcentagens, os valores nas concentrações foram considerados estatisticamente iguais.

Resultados semelhantes foram obtidos no estudo realizado na Estação Marinha de Aqüicultura, em Rio Grande, RS, onde os valores nas concentrações dos grupos $\alpha$-, $\beta$ - $e \gamma$ proteobacteria foram $2,1 \times 10^{7}$ céls $/ \mathrm{mL}, 7,8 \times 10^{5}$ céls $/ \mathrm{mL}$ e $6,4 \times 10^{5}$ céls $/ \mathrm{mL}$, respectivamente e além de serem similares aos aqui encontrados também não apresentaram diferenças estatísticas (OLIVEIRA et al., 2006b).

Maiores porcentagens de células hibridizadas com sondas fluorescentes em relação ao número de células totais foram observadas em água do mar, na Alemanha, onde os grupos predominantes foram $\alpha$-proteobacteria $(27 \%)$ e $\gamma$-proteobacteria $(20 \%)$ (SEKAR et al., 2004). Todavia, outra publicação mostra que $\alpha$-proteobacteria foi o grupo dominante num estudo desenvolvido na costa do Mediterrâneo, apresentando 29\% das células totais coradas com DAPI, mas em compensação o grupo $\gamma$-proteobacteria foi o que menor prevaleceu, apresentando-se com apenas 8\% das células totais (ALONSO-SÁEZ et al., 2007).

A menor freqüência foi vista para o grupo $\delta$-proteobacteria, o qual apresentou, em média, 6,8\% de células hibridizadas em relação ao total de células. Por outro lado, este grupo é dominado pelas bactérias redutoras de sulfato que, apesar de serem encontradas em água do mar, são mais comuns em sedimentos marinhos (WINFREY e WARD, 1983; PARKES et al., 1989; TAKII et al., 2008).

Fatores abióticos podem ter influenciado nos resultados de concentração dos grupos bacterianos, visto que foi observada uma correlação (negativa) entre os valores de condutividade e os quatro grupos estudados. Assim também, foi verificado que as 
concentrações de $\gamma$-proteobacteria podem variar, de acordo com as variações de temperatura, da mesma maneira que foram observadas por Heidelberg et al. (2002).

No geral, a abundância relativa dos grupos bacterianos pesquisados representou $34,6 \%$ da comunidade total presente no Canal de São Sebastião, ou seja, a população pertencente às classes $\alpha$-, $\beta$-, $\gamma$ - e $\delta$-proteobacteria neste local pôde ser observada. Todavia, para se obter dados da composição bacteriana total presente neste local, sondas fluorescentes para detecção de grupos específicos (Cytophaga-Flavobacteria, bactéria gram-positiva com alto e baixo conteúdo de $\mathrm{G}+\mathrm{C}$, bactéria universal) deverão ser usadas.

\subsection{CARACTERIZAÇÃO MOLECULAR DAS POPULAÇÕES BACTERIANAS: CONSTRUÇÃO DE BIBLIOTECAS DO GENE 16S rDNA}

\subsubsection{Seqüenciamento dos clones de $16 \mathrm{~S}$ rRNA}

Após mais de 30 anos do aperfeiçoamento da técnica de sequenciamento (SANGER et $a l ., 1977)$, avanços nesta técnica ainda estão transformando a visão dos pesquisadores no que diz respeito à distribuição e diversidade de organismos. Um exemplo de como a técnica de sequenciamento mudou essa visão ocorreu quando foi descoberta a presença de Archaea em águas superficiais oceânicas (DeLONG, 1992; FUHRMAN et al., 1992).

O gene 16S rDNA é o que mais está sendo utilizado para determinar a presença de membros dos domínios Bacteria e Archaea em uma amostra ambiental. Estudos envolvendo sequências de $16 \mathrm{~S}$ rRNA clonadas diretamente do ambiente não é de hoje que já estão sendo feitos (GIOVANNONI et al., 1990; BRITSCHI e GIOVANNONI, 1991; SCHMIDT et al., 1990; TRINGE et al., 2005; DeLONG, 2005).

A construção de três bibliotecas de clones feitas com sequências parciais do gene $16 \mathrm{~S}$ rDNA de amostras coletadas em três meses diferentes no Canal de São Sebastião mostrou uma parte da comunidade bacteriana presente no local e também permitiu verificar que, dentre os três meses analisados, não houve diferença na composição dessas bibliotecas no que se refere ao nível de Filo.

Apesar de cada biblioteca ter apresentado um filo que foi específico para cada uma (Fusobacteria para a biblioteca 1; Verrucomicrobia para a biblioteca 2; Chloroflexi para a biblioteca 3) estes filos foram representados por apenas uma sequência de clone. Dessa forma, 
como cada biblioteca construída equivale a um mês diferente, não se pode inferir que estes filos são exclusivos de uma determinada época do ano.

O filo Proteobacteria dominou a comunidade nas três bibliotecas. Este filo é o maior e mais diverso grupo filogenético fenotipicamente (KERSTERS et al., 2006), além de ser abundante em ecossistemas marinhos (ROLLER et al., 1994; RAPPÉ et al., 1997; COTTRELL e KIRCHMAN, 2000a). Este filo é composto por cinco classes: Alphaproteobacteria, Betaproteobacteria, Gammaproteobacteria, Deltaproteobacteria e Epsilonproteobacteria que são distribuídas de forma generalizada em ambientes aquáticos e terrestres (LEE et al., 2005).

Essas classes, com exceção da Epsilonproteobacteria, foram representadas nas bibliotecas de água aqui construídas. A maior abundância foi de Alphaproteobacteria, tanto para os clones que foram classificados como para aqueles que não puderam ser classificados dentro de nenhuma família dessa classe (Unclassified Alphaproteobacteria). No entanto, vale ressaltar que, para os clones que foram classificados dentro dessa classe, a maior frequiência encontrada foi na biblioteca 2, enquanto que os não classificados foram predominantes na biblioteca 1. A classe Alphaproteobacteria é dominante em ecossistemas marinhos e, assim como neste trabalho a presença dessa classe foi prevalente, em outros estudos sua dominância também já foi relatada (GIOVANNONI et al., 1995; MULLINS et al., 1995; KIRCHMAN et al., 2005).

A classe Betaproteobacteria esteve presente nas bibliotecas 1 e 2, embora entre os clones identificados nessa classe tenha sido observada a maior freqüência na biblioteca $1 \mathrm{e}$ maior frequiência na biblioteca 2 para os clones que não puderam ser classificados dentro das famílias dessa classe (Unclassified Betaproteobacteria). Essa classe bacteriana possui seus representantes no ambiente marinho, mas é predominante em ambientes de água doce (METHE et al., 1998; COTTRELL et al., 2005; KIRCHMAN et al., 2005).

Gammaproteobacteria é o maior grupo do filo Proteobacteria abrigando 13 ordens (GARRITY et al., 2005). Nas bibliotecas construídas, essa classe foi a que apareceu com maior frequiência, após a Alphaproteobacteria. Da mesma maneira como aconteceu para as duas classes já citadas, alguns clones só puderam ser identificados como pertencentes a essa classe, não sendo possível identificá-los em ordem (Unclassified Gammaproteobacteria). Isso ocorreu com a maioria dos clones obtidos nas três bibliotecas. Por outro lado, clones identificados que se distribuíram nessa classe e que puderam ser inseridos dentro de alguma ordem só estiveram presentes nas bibliotecas 1 e 2 . A dominância das classes 
Alphaproteobacteria e Gammaproteobacteria, nessa ordem, em bibliotecas de clones também foi verificada no estudo desenvolvido com amostras de água da costa da Califórnia (COTTRELL e KIRCHMAN, 2000a).

A última classe do filo Proteobacteria e também a menos frequente que foi identificada nas sequências de clones deste trabalho foi a Deltaproteobacteria. Apenas uma sequência foi identificada e mesmo assim ela não obteve nenhuma classificação, quanto ao nível de ordem, nesta classe.

$\mathrm{O}$ fato dessas sequências de clones terem sido sequenciadas apenas parcialmente ( $600 \mathrm{pb})$ pode ser um dos motivos pelos quais muitos clones não puderam ter sido identificados em alguns níveis filogenéticos, sendo denominados neste estudo como Unclassified.

Representantes do filo Bacteroidetes também foram verificados nas três bibliotecas de água, embora com maior freqüência nas bibliotecas 1 e 2 . Este filo possui membros que podem representar entre $6 \%$ a $30 \%$ das bactérias encontradas nos oceanos (COTTRELL e KIRCHMAN, 2000b; EILERS et al., 2000). Este filo possui três classes (Bacteroidetes, Flavobacteria e Sphingobacteria), das quais apenas a Flavobacteria foi encontrada neste trabalho. Essa classe é ubíqua em ambientes marinhos (KIRCHMAN, 2002) e possui importantes bactérias patogênicas a animais marinhos (LaFRENTZ et al., 2004).

O filo Cyanobacteria também foi representado por sequências encontradas na água do mar do Canal de São Sebastião. Nas bibliotecas 1 e 2 este filo foi o que mais predominou, após o filo Proteobacteria. Já na biblioteca 3 sua freqüência foi baixa (2,1\%). Abrangendo bactérias Gram-negativas fotoautotróficas que utilizam o $\mathrm{CO}_{2}$ como fonte de carbono e a água como agente redutor este filo é considerado o maior grupo taxonômico entre as bactérias (WOESE et al., 1985; GARRITY e HOLT, 2001).

O filo Firmicutes foi representado por apenas duas sequências, uma na biblioteca 1 e outra na biblioteca 2. Bactérias que pertencem a esse filo são gram-positivas e são separadas em dois grandes grupos, de acordo com o teor de Guanina e Citosina $(\mathrm{G}+\mathrm{C})$ no DNA (GARRITY e HOLT, 2001). Este filo é dividido em três classes (Bacilli, Clostridia e Erysipelotrichi), das quais as duas sequências encontradas foram identificadas na classe Clostridia que está dentro do grupo de bactérias com baixo conteúdo de G+C.

Os filos Fusobacteria, Verrucomicrobia e Chloroflexi foram exclusivos das bibliotecas 1, 2 e 3, respectivamente. Todavia foram representados por apenas uma sequência em cada biblioteca. O filo Verrucomicrobia foi proposto como uma nova divisão entre o 
domínio Bacteria em 1997 (HEDLUND et al., 1997) e em 2001 foi classificado como filo (GARRITY e HOLT, 2001). Membros deste filo apresentam-se distribuídos em diversos ambientes (HUGENHOLTZ et al., 1998a). O filo Choloflexi é representado por bactérias verdes não-sulfurosas e formam um grupo complexo de bactérias recentemente reclassificadas em cinco classes (HUGENHOLTZ e STACKBRANDT, 2004). Dessas classes, apenas uma, Anaerolinea, foi detectada na biblioteca 3 .

Além dessas sequências classificadas dentro dos filos mencionados, 7,3\%, 10,7\% e $14,9 \%$ das sequências das três bibliotecas não puderam ser classificadas em nível de filo. Da mesma maneira como ocorreu com as sequências do filo Proteobacteria, talvez o fato de ter sido seqüenciado apenas parte da região $16 \mathrm{~S}$ rRNA tenha influenciado o resultado. Sequenciar outras regiões do gene 16S rDNA pode ser uma solução para classificar esses clones dentro de algum filo ou até mesmo chegar a outro nível filogenético.

\subsection{2 Índices de Diversidade e Riqueza das bibliotecas gênicas}

Os métodos baseados na análise das sequências de 16S rRNA para estudos da diversidade de bactérias apresentam uma série de limitações, tais como o viés da PCR em favor de grupos mais dominantes, a variabilidade genética do fragmento do gene analisado e o número de sequências analisadas em relação à riqueza de espécies. Todavia, são capazes de fornecer informações que métodos baseados em cultivo não fornecem. Assim, apenas uma fração da diversidade existente é efetivamente analisada e as estimativas do número de filotipos e índices de diversidade, muitas vezes, representam aproximações que não são reais, ficando claro quando se observa as variações dos intervalos de confiança das estimativas.

Estimativas de riqueza baseadas em Chao1 utilizam o número de espécies que ocorrem uma ou poucas vezes para estimar o número de espécies desconhecidas, a qual é informada pelo número de espécies de baixa freqüência (CHAO, 1984; CHAO et al., 2006). Já o estimador baseado na cobertura de abundância (ACE) separa as espécies observadas em grupos de filotipos raros e abundantes e utiliza somente o grupo de espécies raras para estimar o número de espécies desconhecidas (CHAO e LEE, 1992; CHAO et al., 1993).

Outra medida quantitativa de diversidade comumente utilizada em estudos ecológicos é o índice de Shannon que emprega aproximações matemáticas independentes para medir a diversidade. Este índice considera a riqueza ou o número de diferentes espécies encontradas nas diferentes áreas, considerando a equitabilidade ou igualdade da distribuição de indivíduos 
destas espécies, evidenciando, assim, o peso das espécies raras ou de baixa frequiência encontradas em cada área (MAGURRAN, 1988).

Os índices de estimativas e riqueza descritos foram aplicados neste estudo e mostraram que, apesar dos valores encontrados na biblioteca 3 serem diferentes, se comparados com as outras duas bibliotecas, a composição das três bibliotecas não diferem uma da outra em termos de número e diversidade de filos encontrados. É visivelmente notado que o número de filotipos (OTUs) e os valores dos índices de diversidade e estimativas de riqueza são diferenciados para a biblioteca 3. Isso pode ter ocorrido pelo fato do número sequências de clones forward e reverse obtidos nessa biblioteca ter sido diferente dos obtidos nas outras bibliotecas, ou seja, enquanto para as bibliotecas 1 e 2 o número de sequências forward e reverse, nessa ordem, foi 71 e 21 e 78 e 15, respectivamente, para a biblioteca 3 esses números foram 56 sequências forward e 38 reverse.

Tem sido demonstrado que comunidades de microrganismos apresentam variações de abundância, distribuição e diversidades em variadas escalas espaciais e taxonômicas, devido à influência de uma grande quantidade de fatores bióticos e abióticos (MARTINY et al., 2006). Segundo esse mesmo autor, a biogeografia dos microrganismos, ou seja, a distribuição espacial e temporal da biodiversidade é definida por dois conjuntos de fatores: um refere-se a aspectos contemporâneos como variações de condições ambientais, o outro, a aspectos históricos como o isolamento continental.

Além desses fatores, o número de espécies detectadas em uma amostra ou o número de organismos identificados dentro de um dado nível taxonômico é fortemente afetado pelo número de sequências analisadas (SCHLOSS e HANDELSMAN, 2006). Sendo assim, as estimativas de riqueza de espécies bacterianas encontradas neste estudo apontam para a necessidade de um aumento no esforço amostral para uma completa caracterização da diversidade do local estudado, pois o número de sequências analisadas pode não ter sido suficiente para representar e diferenciar a diversidade mensal do Canal de São Sebastião.

\subsection{COMPARAÇÃO ENTRE AS METODOLOGIAS EMPREGADAS}

Neste estudo foram empregadas metodologias diferentes para quantificar a concentração e diversidade bacteriana no Canal de São Sebastião, assim como sua identificação. Portanto, faz-se necessário comparar rapidamente cada resultado obtido com uma determinada técnica com os outros verificados com metodologias diferentes. 
A concentração de bactérias marinhas foi verificada através da contagem em placa utilizando o meio Ágar Marinho. Esta metodologia favorece apenas o crescimento de microrganismos que são viáveis em meios de cultivo o que já foi demonstrado que representa uma fração muito pequena da concentração realmente existente no ambiente (WARD et al., 1990; AMANN et al., 1995).

Por outro lado, técnicas de contagem direta sem a necessidade do cultivo bacteriano foram desenvolvidas e estão sendo empregadas para estimar a concentração bacteriana total de um determinado ambiente (DALEY, 1979; PORTER e FEIG, 1980; FRY, 1988; HERBERT, 1990). Neste estudo, essa concentração foi verificada através da contagem de células totais coradas com DAPI (corante que marca ácidos nucléicos) e os resultados mostraram uma diferença de cinco a seis ordens de magnitudes entre a concentração bacteriana obtida pela contagem em placa e a contagem direta pela coloração com DAPI.

Essa discrepância nas concentrações foi classificada de "a grande anomalia da placa" para descrever a pequena proporção de bactérias que podem formar colônias quando técnicas de plaqueamento são utilizadas (STALEY e KONOPKA, 1985). Esses resultados confirmam a eficiência da metodologia de coloração com DAPI para estimar a concentração microbiana, mas por outro lado, a vantagem da contagem em placa é que permite isolar as bactérias para melhor caracterizá-las.

As bactérias marinhas foram identificadas pelo seqüenciamento parcial da região $16 \mathrm{~S}$ rRNA, porém antes de serem identificadas por essa técnica foram submetidas à tipagem molecular através da amplificação com iniciadores de sequências repetitivas (BOX-PCR e ERIC-PCR), a fim de se obter um perfil comum e poder seqüenciar apenas aqueles que fossem mais representativos. No entanto, as técnicas de ribotipagem não permitiu selecionar bactérias que fossem representativas, visto que os perfis gerados foram muito diversificados, levando a seqüenciar praticamente todas as bactérias marinhas isoladas da placa do meio de cultivo.

Por outro lado, o resultado do seqüenciamento mostrou que $87 \%$ dessas bactérias foram identificadas como sendo pertencentes ao gênero Vibrio, o que nos leva a pensar que perfis comuns deveriam ter sido formados pelas técnicas de fingerprintings (BOX-PCR e ERIC-PCR). Em contraste, essas técnicas de fingerprinting são muito utilizadas para analisar a diversidade entre linhagens, como no caso de Vibrio cholerae, Escherichia coli, Yersinia enterocolítica e Klebsiella pneumonia (VERSALOVIC et al., 1991; de BRUIJN, 1992). 
Pelo fato do sequenciamento ter identificado $87 \%$ das bactérias marinhas como sendo do gênero Vibrio, não podemos assumir que são da mesma espécie, principalmente que são Vibrio cholerae, já que dentro desse gênero essa é a espécie que tem sido mais relatada no que se refere a utilização desses iniciadores. Além disso, já foi relatado que o ambiente aquático serve como um reservatório de genes ( $\mathrm{ZO}$ et al., 2002) e, assim como o V. cholerae pode adquirir novos genes por transferência horizontal de genes (MEIBOM et al., 2005) também não podemos descartar a possibilidade das bactérias marinhas isoladas neste trabalho estar passando pelos mesmos processos.

Outra comparação que é cabível de ser feita é a concentração de células pertencentes aos grupos Alphaproteobacteria, Betaproteobacteria, Gammaproteobacteria e Deltaproteobacteria detectadas pela técnica de hibridização in situ (FISH) e os resultados da identificação das sequências de bibliotecas de clones bacterianos pela técnica de seqüenciamento. Pela técnica de hibridização foi verificado que a maior concentração de células foi para a classe Betaproteobacteria, embora dados estatísticos tenham mostrado que a concentração de células para as classes Alphaproteobacteria e Gammaproteobacteria não foram diferentes se comparadas essas três concentrações. Em contraste, as bibliotecas de clones mostraram maior prevalência da classe Alphaproteobacteria.

Sabe-se que a biblioteca de clones de genes $16 \mathrm{~S}$ rDNA é o método que está mais sendo usado para analisar a diversidade bacteriana e esse método tem mostrado que a comunidade microbiana marinha contém espécies novas não cultivadas que estão distribuídas pelos oceanos (DeLONG et al., 1993; FUHRMAN et al., 1993; GIOVANNONI e RAPPÉ, 2000). No entanto, analisar a diversidade bacteriana utilizando técnicas que não utilizem a PCR também se faz necessário, como no caso da técnica de FISH. Já foi demonstrado que os resultados das duas técnicas, quando aplicadas em amostras de coluna d'água, foram diferentes (COTTRELL e KIRCHMAN, 2000).

No caso desse estudo mencionado, os autores mostraram que a classe Alphaproteobacteria dominou o ambiente marinho quando a biblioteca de clones foi aplicada, enquanto que a técnica de FISH indicou que o grupo mais abundante foi o CytophagaFlavobacter quando essas duas técnicas foram empregadas no mesmo tipo de amostra. Os autores ainda sugerem que os iniciadores utilizados na amplificação do gene 16S rDNA são iniciadores que amplificam bactérias em geral, podendo superestimar a abundância de alguns grupos e subestimar a de outros.

De maneira similar pode ter ocorrido com as diferenças encontradas entre os resultados dessas duas técnicas quando aplicadas nas amostras do presente estudo, mas deve- 
se lembrar que a técnica de FISH foi aplicada para quantificar apenas os grupos das proteobactérias e que, para se obter uma estimativa da abundância bacteriana total no Canal de São Sebastião, outras sondas deveriam ter sido empregadas.

Diante disso, a aplicação de diversas técnicas é fundamental para estudar a diversidade bacteriana, haja vista que um fator limitante para a falta de conhecimento da diversidade microbiana em amostras de água do mar pode estar, em grande parte, relacionada às limitações das metodologias empregadas. 


\section{CONCLUSÕES}

1. Não houve influência de variações sazonais nas concentrações de bactérias marinhas viáveis.

2. As técnicas de BOX-PCR e ERIC-PCR não foram discriminativas, no que se refere a diferenciar as bactérias marinhas em grupos filogenéticos. Todavia, a técnica de BOX-PCR foi mais sensível para essas amostras.

3. A diversidade de bactérias marinhas foi caracterizada molecularmente pela predominância do gênero Vibrio $(\sim 87 \%)$.

4. A maior abundância relativa entre os grupos bacterianos foi de Betaproteobacteria. Contudo, não houve diferença estatística entre as concentrações desse grupo e as dos grupos Alphaproteobacteria e Gammaproteobacteria.

5. A comunidade total da água do mar foi caracterizada pela predominância do filo Proteobacteria e por membros da classe Alphaproteobacteria.

6. A maior concentração bacteriana foi verificada pela técnica de contagem direta usando o corante DAPI.

7. A diversidade bacteriana cultivada foi diferente da diversidade bacteriana total, em relação ao nível filogenético de classe. Porém, foi semelhante no que diz respeito ao filo. 


\section{REFERÊNCIAS BIBLIOGRÁFICAS*}

ABOIM, M.C.R.; COUTINHO, H.L.C.; PEIXOTO, R.S.; BARBOSA, J.C.; ROSADO, A.S. Soil bacterial community structure and soil quality in a slash-and-burn cultivation system in Southeastern Brazil. Applied Soil Ecology, v. 38, p. 100-108, 2008.

AGÊNCIA NACIONAL DE VIGILÂNCIA SANITÁRIA. Relatório Técnico. Diagnóstico microbiológico de áreas de risco nos portos de Santos, Paranaguá, Recife, Belém, Fortaleza, Rio Grande e Sepetiba. Brasília: ANVISA, 2004.

AIDAR, E.; GAETA, S.A.; GIANESELLA-GALVÃO, S.M.F.; KUTNER, M.B.B.; TEIXEIRA, C. Ecossistema costeiro subtropical: nutrientes dissolvidos, fitoplâncton e clorofila- $a$ e sua relações com as condições oceanógrafas na região de Ubatuba, SP. Publicação Especial do Instituto Oceanográfico, São Paulo, v. 10, p. 9-43, 1993.

ALONSO-SÁEZ, L.; BALAGUK, V.; SA, E.L.; SANCHEZ, O.; GONZALEZ, J.M.; PINHASSI, J.; MASSANA, R.; PERNTHALER, J.; PEDROS-ALIO, C.; GASOL, J.M. Seasonality in bacterial diversity in north-west Mediterranean coastal waters: assessment through clone libraries, fingerprinting and FISH. FEMS Microbiology Ecology, v. 60 (1), p. 98-112, 2007.

ALTSCHUL, S.F.; GISH, W.; MILLER, W.; MYERS, E.W.; LIPMAN, D.J. Basic local alignment search tool. Journal of Molecular Biology, v. 215, p. 403-410, 1990.

AMANN, R.; BINDER, B.J.; OLSON, R.J.; CHISHOLM, S.W.; DEVEREUX, R., STAHL, D.A. Combination of $16 \mathrm{~S}$ rRNA-targeted oligonucleotide probes with flow cytometry for analyzing mixed microbial populations. Applied and Environmental Microbiology, v. 56, p. 1919-1925, 1990.

AMANN, R.I.; LUDWIG, W.; SCHLEIFER, K.H. Phylogenetic identification and in situ detection of individual microbial cells without cultivation. Microbiological Reviews, v. 59, p. 143-169, 1995.

AMANN, R.; LUDWIG, W. Ribosomal RNA-targeted nucleic probes for studies in microbial ecology. FEMS Microbiology Reviews, v. 24, p. 555-656, 2000.

\footnotetext{
* De acordo com:

ASSOCIAÇÃO BRASILEIRA DE NORMAS TÉCNICAS. NBR 6023: Informação e documentação: referências: elaboração. Rio de Janeiro, 2002
} 
AMANN, R.; FUCHS, B.M.; BEHRENS, S. The identification of microorganisms by fluorescence in situ hybridization. Current Opinion in Biotechnology, v. 12, p. 231- 236, 2001.

AMANN, R.; FUCHS, B.M. Single-cell identification in microbial communities by improved fluorescence in situ hybridization techniques. Nature Reviews, v. 6, p. 339-348, 2008.

AMERICAN PUBLIC HEALTH ORGANIZATION. Microbiological examination. In: APHA (Ed.). Microbiological Examination of Water and Wastewater. 20th ed. Washington, D.C.: APHA, AWWA, WEF, 1998.

AMERICAN PUBLIC HEALTH ASSOCIATION. Microbiological Examination. In: EATON, A.D. (Ed.). Standard Methods for the examination of water and wastewater. 21th ed. Washington, D.C.: APHA, 2005.

ANDREOTE, F.D. Fatores determinantes na composição na comunidade bacteriana associada às plantas. Tese (Doutorado em Agronomia) - Escola Superior de Agricultura Luiz de Queiroz, Universidade de São Paulo, São Paulo, 2007.

ANDREOTE, F.D.; CARNEIRO, R.T.; SALLES, J.F.; MARCON, J.; LABATE, C.A.; AZEVEDO, J.L.; ARAÚJO, W.L. Culture-independent assessment of rhizobiales-related alphaproteobacteria and the diversity of methylobacterium in the rhizosphere and rhizoplane of transgenic eucalyptus. Microbial Ecology, v. 57, p. 82-93, 2009.

ANZAI, Y.; KIM, H.; PARK, J.-Y.; WAKABAYASHI, H.; OYAIZU, H. Phylogenetic affiliation of the pseudomonads based on 16S rRNA sequence. International Journal of Systematic and Evolutionary Microbiology, v. 50, p. 1563-1589, 2000.

ARAHAL, D.R.; MACIÁN, M.C.; GARAY, E.; PUJALTE, M.J. Thalassobius mediterraneus gen. nov., sp. nov., and reclassification of Ruegeria gelatinovorans as Thalassobius gelatinovorus comb. nov. International Journal of Systematic and Evolutionary Microbiology, v. 55, p. 2371-2376, 2005.

ATLAS, R.M.; BARTHA, R. Microbial Ecology - fundamentals and applications. Redwood City: Benjamin-Cummings Plublishing Co., 1993.

AUSTIN, B.; GARGES, S.; CONRAD, B.; HARDING, E.E.; COLWELL, R.R.; SIMIDU, U.; TAGA, N. Comparative study of the aerobic, heterotrophic bacterial flora of Chesapeake Bay and Tokyo Bay. Applied and Environmental Microbiology, v. 37, p. 704-714, 1979. 
AUSTIN, B.; RODGERS, C.J.; FORNS, J.M.; COLWELL, R.R. Alcaligenes faecalis subsp. homari subsp. nov., a new group of bacteria isolated from moribund lobsters. International Journal of Systematic Bacteriology, v. 31, p. 72-76, 1981

AVANISS-AGHAJANI, E.; JONES, K.; CHAPMAN, D.; BRUNK, C. A molecular technique for identification of bacteria using small subunit ribosomal RNA sequences. BioTechniques, v. 17, p. 144-149, 1994.

AZAM, F.; FENCHEL, T.; FIELD, J.G.; GRAY, J.S.; MEYER-REIL, L.A.; THINGSTAD, F. The ecological role of water-column microbes in the sea. Marine Ecology Progress Series, v. 10, p. 257-263, 1983.

AZAM, F.; AMMERMAN, J.W. Cycling of organic matter by bacterioplankton in pelagic marine ecosystems: microenvironmental considerations. In: FASHAM, M. J. R. (Ed.). Flows of Energy and Materials in Marine Ecosystem. New York: Pergamon Press, 1984. p. 345360 .

AZAM, F.; WORDEN, A.Z. Microbes, molecules and marine ecosystems. Science, v. 303, p. 1622-1624, 2004.

AZAM, F.; MALFATTI, F. Microbial structuring of marine ecosystems. Nature Reviews, v. 5, p. 782-792, 2007.

BACHMANN, K. Species as units of diversity: an outdated concept. Theory in Biosciences, v. 117, p. 213-230, 1998.

BAJ, J. Taxonomy of the genus Paracoccus. Acta Microbiologica Polonica, v. 49, p. 185200, 2000.

BALOWS, A.; TRUPER, H.G.; DWORKIN, M.; HARDER, W.; SCHLEIFER, K.H. The Prokaryotes. New York: Springer-Verlag, 1992.

BARBIERI, E.; FALZANO, L.; FIORENTINI, C.; PIANETTI, A.; BAFFONE, W.; FABBRI, A.; MATARRESE, P.; CASIERE, A.; KATOULI, M.; KUHN, I.; MOLLBY, R.; BRUSCOLINI, F.; DONELLI, G. Occurrence, diversity, and pathogenicity of halophilic Vibrio spp. and non-O1 Vibrio cholerae from estuarine waters along the Italian Adriatic coast. Applied and Environmental Microbiology, v. 65, p. 2748-2753, 1999.

BAUMANN, L.; BAUMANN, P.; MANDEL, M.; ALLEN, R.D. Taxonomy of aerobic marine eubacteria. Journal of Bacteriology, v. 110, p. 402-429, 1972. 
BAUMANN, P.; BAUMANN, L. The marine gram-negative eubacteria: genera Photobacterium, Beneckea, Alteromonas, Pseudomonas, and Alcaligenes. In: STARR, M.P.; STOLP, H.; TRÜPER, H.G.; BALOWS, A.; SCHLEGEL, H.G. (Ed.). The prokaryotes. Berlim: Springer-Verlag, 1981. p. 1302-1331.

BEIJERINCK, M.W. Le Photobacterium luminosum, bacteria lumineuse de la Mer du Nord. Archives Néerlandaises des Sciences Exactes et Naturelles, v. 23, p. 401-427, 1889.

BÉJÁ, O.; SUZUKI, M.T.; KOONIN, E.V.; ARAVIND, L.; HADD, A.; NGUYEN, L.P.; VILLACORTA, R.; AMJADI, M.; GARRIGUES, C.; JOVANOVICH, S.B.; FELDMAN, R.A.; DELONG, E.F. Construction and analysis of bacterial artificial chromosome libraries from a marine microbial assemblage. Environmental Microbiology, v. 2, p. 516-529, 2000.

BERNARD, L.; SCHÄFER, H.; JOUX, F.; COURTIES,C.; MUYZER, G.; LEBARON, P. Genetic diversity total, active and culturable marine bacteria in coastal seawater. Aquatic Microbial Ecology, v. 23, p. 1-11, 2000.

BIANCHI, A. Polyphasic study of the microbial ecology of bacteria phytoplankton interactions. In: COLWELL, R.R.; FOSTER, J.A. (Ed.) Aquatic Microbial Ecology. College Park: Maryland Sea Grant Publication, 1980. p. 372-376.

BILLEN, G.; JOURIS, C.; MEYER-REIL, L.A.; LINDEBLOOM, H. Role of bacteria in the North Sea ecosystem. Journal of Sea Research, v. 26, p. 265-293, 1990.

BJÖRNSEN, P.K.; KUPARINEN, J. Determination of bacterioplankton biomass, net production and growth efficiency in the Southern Ocean. Marine Ecology Progress Series, v. 71, p. 185-194, 1991.

BOND, P.L.; HUGENHOLTZ, P.; KELLER, J.; BLACKALL, L.L. Bacterial community structures of phosphate-removing and non- phosphate-removing activated sludges from sequencing batch reactors. Applied and Environmental Microbiology, v. 61, p. 1910-1916, 1995.

BORNEMAN, J.; TRIPLETT, E. W. Molecular microbial diversity in soils from eastern Amazonia: evidence for unusual microorganisms and microbial population shifts associated with deforestation. Applied and Environmental Microbiology, v. 63, p. 2647-2653, 1997.

BOWDEN, W.B. Comparison of two direct-count techniques for enumerating aquatic bacteria. Applied Environmental Microbiology, v. 33, p. 1229-1232, 1977. 
BRENNER, D.J.; STALEY, J.T.; KRIEG, N.R. Classification of prokaryotic organisms and the concept of bacterial speciation. In: BRENNER, D.J.; KRIEG, N.R.; STALEY, J.T. Bergey's Manual $^{\circledR}$ of Systematic Bacteriology. 2nd ed. East Lansing: Springer, 2005. v. 2, Part A.

BRITSCHGI, T.B.; GIOVANNONI, S.J. Phylogenetic analysis of a natural marine bacterioplankton population by rRNA gene cloning and sequencing. Applied and Environmental Microbiology, v. 57, p. 1707-1713, 1991.

BROSIUS, J.; DULL, T.J.; SLEETER, D.D.; NOLLER, H.F. Gene organization and primary structure of a ribosomal RNA operon from Escherichia coli. Journal of Molecular Biology, v. 148 , p. 107-127, 1981.

BRUNS, A.; CYPIONKA, H.; OVERMANN. J. Cyclic AMP and acyl Homoserine lactones increase the cultivation efficiency of heterotrophic bacteria from the Central Baltic Sea. Applied and Environmental Microbiology, v. 68, p. 3978-3987, 2002.

BRUNS, A.; NÜBEL, U.; CYPIONKA, H.; OVERMANN, J. Effect of signal compounds and incubation conditions on the culturability of freshwater bacterioplankton. Applied and Environmental Microbiology, v. 69, p. 1980-1989, 2003.

BUCHANAN, R.E.; HOLT, J.G.; LESSEL, E.F. Index Bergeyana. Baltimore: Willian and Wilkins Co., 1966. p. 803-806.

BUCK, J.D. Nonstaining $(\mathrm{KOH})$ method for determination of Gram reactions of marine bacteria. Applied and Environmental Microbiology, v. 44, p. 992-993, 1982.

BUCKLEY, M.; ROBERTS, R.J. Reconciling microbial systematics \& genomics. A report from the American Academic of Microbiology, 2006.

BULL, A.T.; STACH, J.E.M. An overview of biodiversity: estimating the scale, p. 15-28. In: BULL, A.T. (Ed.). Microbial Diversity and Bioprospecting. Washington, D.C.: ASM Press, 2004.

BURBANO-ROSERO, E.M. Freqüiência e diversidade de colifagos somáticos isolados de amostras de água do mar, plâncton e bivalves da baixada Santista, Canal de São Sebastião e Ubatuba. 178 f. Tese (Doutorado em Ciências) - Instituto de ciências Biomédicas, Universidade de São Paulo, São Paulo, 2009. 
CARR, N.G.; MANN, N.H. The oceanic cyanobacterial picoplankton. In: BRYANT, D.G. (Ed.). The Molecular Biology of Cyanobacteria. Kluwer Academic Publishers, 1994. p. 27 48.

CASAMAYOR, E.O.; PEDRÓS-ALIÓ, C.; MUYZER, G.; AMANN, R. Microheterogeneity in $16 \mathrm{~S}$ ribosomal DNA-defined bacterial populations from a stratified planktonic environment in related to temporal changes and to ecological adaptations. Applied and Environmental Microbiology, v. 68, p. 1706-1714, 2002.

CASTELlANI, A.; CHALMERS, H.B. Manual of tropical medicine. 3rd. ed. New York: Willians Wood and Co., 1919.

CASTRO, B.M. Correntes e Massas de Água da Plataforma Continental Norte de São Paulo. 248 f. Tese de Livre-Docência - Instituto Oceanográfico, Universidade de São Paulo, São Paulo, 1996.

CASTRO FILHO, B.M.; MIRANDA, L.B.; MIYAO, S.Y. Condições hidrográficas na Plataforma Continental ao largo de Ubatuba: variações sazonais e em média escala. Boletim do Instituto Oceanográfico, v. 35, n. 2, p. 135-151, 1987.

CASTRO FILHO, B.M. Wind driven currents in the Chanel of São Sebastião: winter 1979. Boletim do Instituto Oceanográfico, v. 38, p. 111-132. 1990.

CAVALIER-SMITH, T. The neomuran origin of archaebacteria, the negibacterial root of the universal tree and bacterial megaclassification. International Journal of Systematic and Evolutionary Microbiology, v. 52, p. 7-76, 2002.

CAVALLO, R.A.; RIZZI, C.; VOZZA, T.; STABILI, L. Viable heterotrophic bacteria in water and sediment in 'Mar Piccolo' of Taranto (Ionian Sea, Italy). Journal of Applied Microbiology, v. 86, p. 906-916, 1999.

CHAO, A. Non-parametric estimation of the number of classes in a population. Scandinavian Journal of Statistics, v. 11, p. 265-270, 1984.

CHAO, A.; LEE, S.M. Estimating the number of classes via sample coverage. Journal of the American Statistical Association, v. 87, p. 210-217, 1992.

CHAO, A.; MA, M-C.; YANG,M.C.K. Stopping rule and estimation for recapture debugging with unequal detection rates. Biometrika, v. 80, p. 193-201, 1993. 
CHAO, A.; SHEN, T.J.; HWANG, W.; Application of laplace's boundary-mode approximations to estimate species and shared species richness. Australian and New Zealand Journal of Statistics, v. 48, p. 117-128, 2006.

CHAPIN, F.S., III; ZAVALETA, E.S.; EVINER, V.T.; NAYLOR, R.L.; VITOUSEK, P.M.; REYNOLDS, H.L.; HOOPER, D.U.; LAVOREL, S.; SALA, O.E.; HOBBIE, S.E.; MACK, M.C.; DIAZ, S. Functional and societal consequences of changing biotic diversity. Nature, v. 405, p. 234-242, 2000.

CHÈNEBY, D.; PHILIPPOT, L.; HARTMANN, A.; HÉNAULT, C.; GERMON, J-C. 16S rDNA analysis for characterization of denitrifying bacteria isolated from three agricultural soils. FEMS Microbiology Ecology, v. 34, p. 121-128, 2000.

CHOWDHURY, N.R.; HUQ, A.; XU, B.; MADEIRA, F.J.; COLWELL, R.R. Effect of allum on free living and copepods associated Vibrio cholerae $\mathrm{O} 1$ and O139. Applied and Environmental Microbiology, v. 63, p. 3323-3326, 1997.

COElHO, A. L. Massas de água e circulação no Canal de São Sebastião (SP). $244 \mathrm{f}$. Dissertação (Mestrado em Oceanografia) - Instituto Oceanográfico, Universidade de São Paulo, São Paulo, 1997.

COHAN, F. M. What are bacterial species? Annual Review of Microbiology, v. 56, p. 457487, 2002.

COLLIER, L.; BALOWS, A.; SUSSMAN, M. Topley and Wilson's Microbiology and Microbial Infections. London: Arnold, 1998. v. 2: Systematic Bacteriology.

COLWELL, R.R.; TAMPLIN, M.L.; BRAYTON, P.R.; GAUZENS, A.L.; TALL, B.D.; HERRINGTON, D.; LEVINE, M.M.; HALLS, S.; HUQ, A.; SACK, D.A. Environmental aspects of Vibrio cholerae in transmission of cholera. In: SACK, R.B. \& ZINNAKA, Y. (Ed.). Advances in research on cholera and related diarrheas. Tokyo: KTK Scientific, 1990. p. 327-343.

COLWELL, R.R.; HUQ, A. Vibrios in the environment: viable but nonculturable Vibrio cholerae. In: Vibrio cholerae and Cholera: molecular to global perspectives. Washington D.C.: American Society for Microbiology, 1994. p. 117-133.

COLWELL, R.R.; CLAYTON, R.A.; ORTIZ-CONDE，B.A.; JACOBS，D.; RUSSEKCOHEN, E. The microbial species concept and biodiversity. In: ALLSOPP, D.; COLWELL, 
R.R.; HAWKSWORTH, D.L. (Ed.). Microbial Diversity and Ecosystem Function. Oxon, United Kingdom: CAB International, 1995. p. 3-15.

COLWELL, R.R. Microbial diversity: the importance of exploration and conservation. Journal of Industrial Microbiology and Biotechnology, v. 18, p. 302-207, 1997.

COLWELL, R.R. Microbial diversity in the era of genomics. In: LOGAN, N.A.; LAPPINSCOTT, H.M.; OYSTON, P.C.F. (Ed.). Prokaryotics diversity: mechanisms and significance. UK: Cambridge University Press, 2006. p. 1-18.

COMPANHIA DE TECNOLOGIA DE SANEAMENTO AMBIENTAL. Relatório de Qualidade das Águas Litorâneas no Estado de São Paulo. São Paulo: MMA, 2008.

CONSELHO NACIONAL DO MEIO AMBIENTE. Resolução $n^{\circ}$ 274, 29 de Novembro de 2000.

CONSELHO NACIONAL DO MEIO AMBIENTE. Resolução n 357, 17 de Março de 2005.

COTTRELL, M.T.; KIRCHMAN, D.L. Community composition of marine Bacterioplankton determined by $16 \mathrm{~S}$ rRNA gene clone libraries and fluorescence in situ hybridization. Applied and Environmental Microbiology, v. 66, p. 5116-5122, 2000a.

COTTRELL, M.T.; KIRCHMAN, D.L. Natural Assemblages of Marine Proteobacteria and Members of the Cytophaga-Flavobacter Cluster Consuming Low- and High-MolecularWeight Dissolved Organic Matter. Applied and Environmental Microbiology, v. 66, p. 1692-1697, 2000b.

COTTRELL, M.T.; WAIDNER, L.A.; YU, L.; KIRCHMAN, D.L. Bacterial diversity of metagenomic and PCR libraries from the Delaware River. Environmental Microbiology, v. 7, p. 1883-1895, 2005.

CURTIS, T.P.; SLOAN, W.T.; SCANNELL, J.W. Estimating prokaryotic diversity and its limits. Proceedings of the National Academy of Science USA, v. 99, p. 10494-10499, 2002.

DAI, X.; WANG, B.-J.; YANG, Q.-X.; JIAO, N.-Z.; LIU, S.-J. Yangia pacifica gen. nov., sp. nov., a novel member of the Roseobacter clade from coastal sediment of the East China Sea. International Journal of Systematic and Evolutionary Microbiology, v. 56, p. 529-533, 2006. 
DAS, S.; LYLA, P.S.; KHAN, A. Marine microbial diversity and ecology: importance and future perspectives. Current Science, v. 90, n.10, p. 1325-1332, 2006.

DALEY, R.J. Direct epifluorescence enumeration of native aquatic bacteria: uses, limitations and comparative accuracy. In: COSTERTON, J.W.; COLWELL, R.R. (Ed.). Native aquatic bacteria: enumeration, activity and ecology. ASTM STP 605. Philadelphia: American Society for Testing and Materials, 1979. p. 29-45.

de BRUIJN, F.J. Use of repetitive (repetitive extragenic element and enterobacterial repetitive intergenic consensus) sequences and the polymerase chain reaction to fingerprinting the genomes of Rhizobium meliloti isolates and other soil bacteria. Applied and Environmental Microbiology, v. 58, p. 2180-2187, 1992.

DeLONG, E.F.; WICKHAM, G.; PACE, N. Phylogenetic stains: ribosomal RNA-based probes for the identification of single cells. Science, v. 243, p. 1360-1363, 1989.

DeLONG, E.F. Archaea in coastal marine environments. Proceedings of the National Academy of Sciences of the United States of America, v. 89, p. 5685-5689, 1992.

DeLONG, E.F.; FRANKS, D.G.; ALLDREDGE, A.L. Phylogenetic diversity of aggregateattached versus free-living marine bacterial assemblages. Limnology and Oceanography, v. 38, p. 924-934, 1993.

DeLONG, E.F.; TAYLOR, L.T.; TERENCE, L.M.; PRESTON, C.M. Visualization and enumeration of marine planktonic archaea and bacteria by using polyribonucleotide probes and Fluorescent In Situ Hybridization. Applied and Environmental Microbiology, v. 65, $5554-5563,1999$.

DeLONG, E.F. Microbial seascapes revisited. Current Opinion in Microbiology, v. 4, p. 290-295, 2001.

DeLONG, E.F. Microbial community genomics in the ocean. Nature Reviews Microbiology, v. 3, p. 459-469, 2005.

DIAS, A.C.F.; ANDREOTE, F.D.; DINI-ANDREOTE, F.; LACAVA, P.T.; SÁ, A.L.B.; MELO, I.S.; AZEVEDO, J.L.; ARAÚJO, W.L. Diversity and biotechnological potential of culturable bacteria from Brazilian mangrove sediment. World Journal of Microbiology and Biotechnology, v. 25, p. 1305-1311, 2009. 
DU, H,; JIAO, N.; HU, Y; ZENG, Y. Diversity and distribution of pigmented heterotrophic bacteria in marine environments. FEMS Microbiology Ecology, v. 57, p. 92-105, 2006.

DUCKLOW, H.W. Production and fate of bacteria in the oceans. Bioscience, v. 33, p. 494$501,1983$.

DUCKLOW, H.W.; PURDIE, D.A.; WILlIAMS, P.J. le B.; DAVIES, J.M. Bacterioplankton: A sink for carbon in a coastal marine plankton community. Science, v. 232, p. 865-867, 1986.

DUCKLOW, H.W.; CARLSON, C.A. Oceanic bacterial production. Advances in Microbial Ecology, v. 12, p. 113-181, 1992.

DUCKLOW, H.W.; KIRCHMAN, D.L.; QUINBY, H.L.; CARLSON, C.A.; DAM, H.G. Stocks and dynamics of bacterioplankton carbon during the spring bloom in the eastern North Atlantic Ocean. Deep Sea Research, v. 40, p. 245-263, 1993.

DUIM, B.; VANDAMME, P.A.R.; RIGTER, A.; LAEVENS, S.; DIJKSTRA, J.R.; WAGENAAR, J.A. Differentiation of Campylobacter species by AFLP fingerprinting. Microbiology, v. 147, p. 2729-2737, 2001.

DYKHUIZEN, D.E.; GREEN, L. Recombination in Escherichia coli and the definition of biological species. Journal of Bacteriology, v. 173, p. 7257-7268, 1991.

EILERS, H.; PERNTHALER, J.; GLÖCKNER, F.O.; AMANN. R. Culturability and in situ abundance of pelagic bacteria from the North Sea. Applied and Environmental Microbiology, v. 66, p. 3044-3051, 2000.

ELSER, J.J.; STERNER, R. Ecological Stoichiometry: the biology of elements from molecules to the biosphere. Princeton: Princeton Univ. Press, 2002.

EMILSSON, I. As correntes marítimas no Canal de São Sebastião. Ciência e Cultura, v. 14, p. 269-270, 1962.

ERCOLINI, D.; HILL, P.J.; DODD, C.E.R. Development of a fluorescence in situ hybridization method for cheese using a $16 \mathrm{~S}$ rRNA probe. Journal of Microbiological Methods, v. 52, p. 267-271, 2003. 
EVERETT, K.D.E.; BUSH, R.M.; ANDERSEN, A.A. Emended description of the order Chlamydiales, proposal of Parachlamydiaceae fam. nov. and Simkaniaceae fam. nov., each containing one monotypic genus, revised taxonomy of the family Chlamydiaceae, including a new genus and five new species, and standards for the identification of organisms. International Journal of Systematic Bacteriology, v. 49, p. 415-440, 1999.

FARMER III, J.J.; HICKMAN-BRENER, F.W. The genera Vibrio and Photobacterium. In: DWORKIN, M.; FALKOW, S.; ROSENBERG, E.; SCHLEIFER, K-H.; STACKEBRANDT, E. (Ed.). The Prokaryotes. 3nd ed. New York: Springer, 2006. v. 6. p. 508-563

FARMER III, J.J.; ARDUINO, M.J; HICKMAN-BRENNER, F.W. The genera Aeromonas and Plesiomonas. In: DWORKIN, M.; FALKOW, S.; ROSENBERG, E.; SCHLEIFER, K-H.; STACKEBRANDT, E. (Ed.). The Prokaryotes. 3nd ed. New York: Springer, 2006. v. 6. p. 564-566

FELSKE, A.; WOLTERINK, A.; van LIS, R.; de VOS, W.M.; AKKERMANS, A.D.L. Searching for predominant soil bacteria: 16S rDNA cloning versus strain cultivation. FEMS Microbiology Ecology, v. 30, p. 137-145, 1999.

FERGUSON, R.L.; RUBLEE, P. Contribution of bacteria to standing crop of coastal plankton. Limnology and Oceanography, v. 21, p. 141-145, 1976.

FOSS, S.; HEYEN, U.; HARDER, J. Alcaligenes defragrans sp. nov., description of four strains isolated on alkenoic monoterpenes $((+)$-menthene, $\alpha$-pinene, 2-carene, and $\alpha$ phellandrene) and nitrate. Systematic and Applied Microbiology, v. 21, p. 237-244, 1998.

FREITAS, D.B.; LIMA-BITTENCOURT, C.I.; REIS, M.P.; COSTA, P.S.; ASSIS, P.S.; CHARTONE-SOUZA, E.; NASCIMENTO, A.M.A. Molecular characterization of early colonizer bacteria from wastes in a steel plant. Letters in Applied Microbiology, v. 47, p. 241-249, 2008.

FROESE, R.; BISBY, F.A. (Ed.). Species 2000 \& IT IS Catalogue of Life: Indexing the World's Known Species. CD-ROM. Species 2000. Phillipines: Los Baños, 2002.

FRY, J.C. Determination of biomass. In: AUSTIN, B. (Ed.). Methods in aquatic bacteriology. Chichester, England: John Wiley \& Sons, 1988. p. 27-72.

FRY, N.K.; ROWBOTHAM, T.J.; SAUNDERS, N.A.; EMBLEY, T.M. Direct amplification and sequencing of the $16 \mathrm{~S}$ ribosomal DNA of an intracellular Legionella species recovered by amoebal enrichment from the sputum of a patient with pneumonia. FEMS Microbiology Letters, v. 83, p. 165, 1991. 
FUHRMAN, J.A.; AZAM, F. Bacterioplankton secondary production estimates for coastal waters of British Columbia, Canada, Antarctica, and California, USA. Applied and Environmental Microbiology, v. 39, p. 1085-1095, 1980.

FUHRMAN, J.A.; SLEETER, T.D.; CARLSON, C.A.; PROCTOR, L.M. Dominance of acterial biomass in the Sargasso Sea and its ecological implications. Marine Ecology Progress Series, v. 57, p. 207-217, 1989.

FUHRMAN, J. A. Bacterioplankton roles in cycling of organic matter: the microbial food web. In: FALKOWSKI, P.G., WOODHEAD, A.D. (Ed.). Primary productivity and biogeochemical cycles in the sea. New York: Plenum Press, 1992.

FUHRMAN, J.A.; MCCALLUM, K.; DAVIS, A.A. Novel major archaebacterial group from marine plankton. Nature, v. 356, p. 148-149, 1992.

FUHRMAN, J. A.; MCCALLUM, K.; DAVIS, A. A. Phylogenetic diversity of subsurface marine microbial communities from the Atlantic and Pacific Oceans. Applied and Environmental Microbiology, v. 59, p. 1294-1302, 1993.

FUHRMAN, J. A. Community structure: Bacteria and Archaea. In: HURST, C.J.; CRAWFORD, R.L.; KNUDSEN, G.R.; MCINERNEY, M.J.; STETZENBACH, L.D. (Ed.). Manual of Environmental Microbiology. 2nd ed. Washington, D.C.: ASM Press, 2002.

FUHRMAN, J.A.; HAGSTRÖM, Å. Bacterial and Archaeal community structure and its patterns. In: KIRCHMAN, D.L. (Ed.). Microbial Ecology of the Oceans. 2nd ed. New Jersey: Wiley-Blackwell, 2008. p. 45-90.

FURTADO, V.V. Sedimentação quaternária no Canal de São Sebastião. Publicação especial do Instituto Oceanográfico, v. 11, p. 27-35, 1995.

GARRITY, G.M.; HOLT, J.G. The road map to the Manual. In: BOONE, CASTENHOLZ and GARRITY (Ed.). Bergey's Manual ${ }^{\circledR}$ of Systematic Bacteriology. 2nd ed. New York: Springer, 2001. p. 119-166. v. 1: The archaea and the deeply branching and phototrophic bacteria.

GARRITY, G.M.;BELL, J.A.; LILBURN, T. The revised road map to the Manual. In: BRENNER, D.J., KRIEG, N.R., STALEY, J.T. Bergey's Manual ${ }^{\circledR}$ of Systematic Bacteriology. 2nd ed. East Lansing: Springer, 2005. v. 2, Part A. 
GAUTHIER, G.; GAUTHIER, M.; CHRISTEN, R. Phylogenetic analysis of the genera Alteromonas, Shewanella, and Moritella using genes coding for small-subunit rRNA sequences and division of the genus Alteromonas into the two genera, Alteromonas (emended) and Pseudoalteromonas gen. nov., and twelve new species combinations. International Journal of Systematic Bacteriology, v. 45, p. 755-761, 1995.

GEVERS, D.; COHAN, F.M.; LAWRENCE, J.G.; SPRATT, B.G.; COENYE, T.; FEIL, E.J.; STACKEBRANDT, E.; PEER, Y. van der; VANDAMME, P.; THOMPSON' F.L.; SWINGS, J. Re-evaluating prokaryotic species. Nature Reviews Microbiology, v. 3, p. 733-739, 2005.

GIOVANNONI, S.J.; BRITSCHGI, T.B.; MOYER, C.L.; FIELD, K.G. Genetic diversity in Sargasso Sea bacterioplankton. Nature, v. 345, p. 60-63, 1990.

GIOVANNONI, S.J.; MULLINS, T.D.; FIELD, K.G. Microbial diversity in oceanic systems: rRNA approaches to the study of unculturable microbes. In: JOINT, I. (Ed.). Molecular ecology of aquatic microbes. Springer-Verlag, 1995. p.217-248

GIOVANNONI, S.; RAPPÉ, M. Evolution, diversity and molecular ecology of marine prokaryotes. In: KIRCHMAN, D.L. (Ed.). Microbial ecology of the oceans. New York, N.Y.: Wiley-Liss, 2000. p. 47-84.

GIOVANNONI, S.J.; TRIPP, H.J.; GIVAN, S.; PODAR, M.; VERGIN, K.L.; BAPTISTA, D.; BIBBS, L.; EADS, J.; RICHARDSON, T.H.; NOORDEWIER, M.; RAPPÉ, M.S.; SHORT, J.M.; CARRINGTON, J.C.; MATHUR, E.J. Genome streamlining in a cosmopolitan oceanic bacterium. Science, v. 309, p. 1242-1245, 2005.

GLÖCKNER, F.O.; AMANN, R.; ALFREIDER, A.; PERNTHALER, J.; PSENNER, R.; TREBESIUS, K.; SCHLEIFER, K-H. An in situ hybridization protocol for detection and identification of planktonic bacteria. Systematic and Applied Microbiology, v. 19, p. 403406, 1996.

GLÖCKNER, F.O.; FUCHS, B.M.; AMANN, R. Bacterioplankton compositions of lakes and oceans: a first comparison based on Fluorescence In Situ Hybridization. Applied and Environmental Microbiology, v. 65, p. 3721-3726, 1999.

GOLD, T. The deep, hot biosphere. Proceedings of the National Academy of Science USA, v. 89, p. 6045-6049, 1992. 
GONZALEZ, A.M.; PARANHOS, R.; LUTTERBACH, M.S. Heterotrophic bacteria abundances in Rodrigo de Freitas lagoon (Rio de Janeiro, Brazil). Brazilian Journal of Microbiology, v. 37, p. 428-433, 2006.

GONTANG, E.A.; FENICAL, W.; JENSEN, P.R. Phylogenetic diversity of Gram-positive bacteria cultured from marine sediments. Applied and Environmental Microbiology, v. 73, p. 3272-3282, 2007.

GONZALEZ-ACOSTA, B.; BASHAN, Y.; HERNANDEZ-SAAVEDRA, N.Y.; ASCENCIO, F.; CRUZ-AGÜERRO, G. De la. Seasonal seawater temperatures the major determinant for populations of culturable bacteria in the sediments of an intact mangrove inanarid region. FEMS Microbiology Ecology, v. 55, p. 311-321, 2006.

GORIS, .J; BOON, N.; LEBBE, L.; VERSTRAETE, W.; VOS, P.D. Diversity of activated sludge bacteria receiving the 3-chloroaniline-degradative plasmid pC1gfp. FEMS Microbiology Ecology, v. 46, p. 221-230, 2003.

GORNI, R.; WEBER, R.R. Organochlorine pesticides residues and PCBs in benthic organisms of the inner shelf of the São Sebastião Channel, São Paulo, Brazil. Brazilian Journal of Oceanography, v. 52, n. 2, p. 141-152, 2004.

GOSINK, J.J.; WOESE, C.R.; STALEY, J.T. Polaribacter gen. nov., with three new species, $P$. irgensii, sp. nov., $P$. franzmannii sp. nov., and $P$. filamentus, sp. nov., gas vacuolated polar marine bacteria of the Cytophaga/Flavobacterium/Bacteroides Group and reclassification of "Flectobacillus glomeratus" as Polaribacter glomeratus. International Journal of Systematic and Evolutionary Bacteriology, v. 48, p. 223-235, 1998.

GRIMES, D.J.; SINGLETON; F.L.; COLWELL, R.R. Allogenic succession of marine bacterial communities in response to pharmaceutical waste. Journal of Applied Bacteriology, v. 57, p. 247-261, 1984.

GRIMES, D.; ATWELL, R.W.; BRAYTON, P.R.; PALMER, L.M.; ROLLINS, D.M.; ROSZACK, D.B.; SINGLETON, F.L.; TAMPLIN, M.L.; COLWELL, R.R. The fate of enteric pathogenic bacteria in estuarine and marine environments. Microbiology Science, v. 3, p. 324-329, 1986.

HAGSTRÖM, Å.; LARSSON, U.; HORSTEDT, P.; NORMARK, S. Frequency of dividing cells: a new approach to the determination of bacterial growth rates in aquatic environments. Applied and Environmental Microbiology, v. 37, 805-812, 1979. 
HALL, T. A. BioEdit: a user-friendly biological sequence alignment editor and analysis program for Windows 95/98/NT. Nucleic Acids Symposium Series, v. 41, p. 95-98, 1999.

HAMAKI, T.; SUZUKI, M.; FUDOU, R.; JOJIMA, Y.; KAJIURA, T.; TABUCHI, A.; SEN, K.; SHIBAI, H. Isolation of novel bacteria and actinomycetes using soil-extract agar medium. Journal of Bioscience and Bioengineering, v. 99, p. 485-492, 2005.

HAMMOND, P.M. Described and estimated species numbers: an objective assessment of current knowledge. In: ALLSOPP, D., COLWELL, R.R., HAWKSWORTH, D.L. (Ed.). Microbial Diversity and Ecosystem Function. United Kingdom: CAB International, Wallingford, 1995. p. 29-71

HARDOIM, C.C.P.; COSTA, R.; ARAÚJO, F.V.; HAJDU, E.; PEIXOTO, R.; LINS, U.; ROSADO, A.S.; VAN ELSAS, J.D. Diversity of bacteria in the marine sponge Aplysina fulva in Brazilian coastal Waters. Applied and Environmental Microbiology, v. 75, p. 33313343, 2009.

HARPER, J.L.; HAWKSWORTH, D.L. Preface. In: HAWKSWORTH, D.L. (Ed.). Biodiversity, Measurement and Estimation. London: Chapman \& Hall, 1995. p. 5-12.

HAWKSWORTH, D.L. The magnitude of fungal diversity: the 1.5 million species estimate revisited. Mycological Research, v. 105, p. 1422-1432, 2001.

HAZEN, T.C; FLIERMANS, C.B; HIRSCH, P.; ESCH, G.W. Prevalence and distribution of Aeromonas hydrophila in the United States. Applied and Environmental Microbiology, v. 36, p. 731-738, 1978.

HEAD, I.M; SAUNDERS, J.R.; PICKUP, R.W. Microbial evolution, diversity, and ecology: a decade of ribosomal RNA analysis of uncultivated microorganisms. Microbial Ecology, v. 35, p. 1-21, 1998.

HEDLUND, B.P.; GOSINK, J.J.; STALEY, J.T. Verrucomicrobia div. nov., a new division of the Bacteria containing three new species of Prosthecobacter. Antonie Leeuwenhoek, v. 72, p. 29-38, 1997.

HEIDELBERG, J.F. Seasonal abundance of bacterioplankton populations of bacteria, gamma proteobacteria, Vibrio/Photobacterium, Vibrio vulnificus, Vibrio cholerae/Vibrio mimicus, and Vibrio cincinnatiensis associated with zooplankton in the Choptank River, Maryland. Ph.D. thesis. University of Maryland, College Park, 1997. 
HEIDELBERG, J.F.; HEIDELBERG, K.B.; COLWELL, R.R. Seasonality of Chesapeake Bay bacterioplankton species. Applied and Environmental Microbiology, v. 68, p. 54885497, 2002.

HERBERT, R.A. Methods for enumerating microorganisms and determining biomass in natural environments. Methods in Microbiology, v. 22, p. 1-40, 1990.

HOBBIE, J.E.; DALEY, R.J.; JASPER, S. Use of nucleopore filters for counting bacteria by fluorescence microscopy. Applied and Environmental Microbiology, v. 33, p. 1225-1228, 1977.

HOLT, J.G. Bergey's Manual of Systematic Bacteriology. Baltimore: Willians and Wilkins, 1984.

HOLT, J.G.; KRIEG, N.R.; SNEATH, P.H.A.; STALEY, J.T.; STANLEY, T.W. Bergey's Manual of Determinative Bacteriology. Baltimore: Willians and Wilkins, 1994.

HOOPER, D.U.; CHAPIN, F.S.; III; EWEL, J.J.; HECTOR, A.; INCHAUSTI, P.; LAVOREL, S.; LAWTON, J.H.; LODGE, D.M.; LOREAU, M.; NAEEM, S.; SCHMID, B.; SETÄLÄ, H.; SYMSTAD, A.J.; VANDERMEER, J.; WARDLE, D.A. Effects of biodiversity on ecosystem functioning: a consensus of current knowledge. Ecological Monographs, v. 75, p. 3-35, 2005.

HOPKINSON, C.S.; SHERR, B.F.; WIEBE, W.J. Size fractionated metabolism of coastal microbial plankton. Marine Ecology Progress Series, v. 51, p. 155-166, 1998.

HUGENHOLTZ, P.; GOEBEL, B.M.; PACE, N.R. Impact of culture independent studies on the emerging phylogenetic view of bacterial diversity. Journal of Bacteriology, v. 180, p. 4765-4774, 1998a.

HUGENHOLTZ, P.; PITULLE, K.L.; PACE, N.R. Novel division level bacterial diversity in a Yellowstone hot spring. Journal of Bacteriology, v. 180, p. 366-376, 1998 b.

HUGENHOLTZ, P.; STACKBRANDT, E. Reclassification of Sphaerobacter thermophilus from the subclass Sphaerobacteridae in the phylum Actinobacteria to the class Thermomicrobia (emended description) in the phylum Chloroflexi (emended description). International Journal of Systematic and Evolutionary Microbiology, v. 54, p. 2049-2051, 2004. 
HUNTER-CEVERA, J. The value of microbial diversity. Current Opinion in Microbiology, v. 1, p. 278-285, 1998.

HUNTER-CEVERA, J.; KARL, D.; BUCKLEY, M. Marine Microbial Diversity: the key Earth's habitability. Washington, D.C.: American Academy of Microbiology, 2005.

HUQ, A.; RIVERA, I.N.G.; COLWELL, R.R. Epidemiological significance of viable but nonculturable microorganisms. In: COLWELL, R.R. e GRIMES, D.J. Nonculturable Microorganisms in the Environment. Washington, D.C.: American Society for Microbiology, 2000. p. 301-323.

HUYS, G.; COOPMAN, R.; JANSSEN, P.; KERSTERS, K. High-resolution genotypic analysis of the genus Aeromonas by AFLP fingerprinting. International Journal of Systematic Bacteriology, v. 46, p. 572-580, 1996.

JANSSEN, P.; COOPMAN, R.; HUYS, G.; SWINGS, J.; BLEEKER, M.; VOS, P.; ZABEAU, M.; KERSTERS, K. Evaluation of the DNA fingerprinting method AFLP as a new tool in bacterial taxonomy. Microbiology, v. 142, p. 1881-1893, 1996.

JENSEN, P.R.; MINCER, T.J.; WILLIAMS, P.G.; FENICAL.W. Marine actinomycete diversity and natural product discovery. Antonie Leeuwenhoek, v. 87, p. 43-48, 2005.

JONES, S.E. The marine microbial world: a voyage of discovery. The ISME Journal, v. 1, p. 469-470, 2007.

JUKES, T.H.; CANTOR, C.R. Evolution of protein molecules. In: MUNRO, H.N. (Ed). Mammalian protein metabolism. New York: Academic Press, 1969. p. 21-132.

KARL, D.M. Microbial oceanography: paradigms, processes and promise. Nature Reviews, v. 5, p. 759-769, 2007.

KARL, D.M.; PROCTOR, L. Foundations of microbial oceanography. Oceanography, v. 20, p. 14-25, 2007.

KARNER, M.; FUHRMAN, J.A. Determination of active marine bacterioplankton: a comparison of universal 16S rRNA probes, autoradiography, and nucleoid staining. Applied and Environmental Microbiology, v. 63, p. 1208-1213, 1997. 
KEPNER, R.L., Jr.; PRATT, J.R. Use of fluorochromes for direct enumeration of total bacteria in environmental samples: past and present. Microbiological Reviews, v. 58, n. 4, p. 603-615, 1994.

KERSTERS, K.; DE LEY, J. Genus Alcaligenes Castellani and Chalmers 1919, 936 ${ }^{\mathrm{AL}}$. In: KRIEG, N.R.; HOLT, J.G. Bergey's Manual ${ }^{\circledR}$ of Systematic Bacteriology. Baltimore: Willians and Wilkins, 1984. v. 1, p. 361-373

KERSTERS, K.; de VOS, P.; GILLIS, M.; SWINGS, J.; VANDAMME, P.; STACKEBRANDT, E. Introduction to the Proteobacteria. In: DWORKIN, M.; FALKOW, S.; ROSENBERG, E.; SCHLEIFER, K-H.; STACKEBRANDT, E. (Ed.). The Prokaryotes. 3nd ed. New York: Springer. p. 3-37, 2006. v. 5

KIRCHMAN, D.L. The ecology of Cytophaga-Flavobacteria in aquatic environments. FEMS Microbiology Ecology, v. 30, p. 91-100,2002.

KIRCHMAN, D.L.; DITTEL, A.I.; MALMSTROM, R.R.; COTTRELL, M.T. Biogeography of major bacterial groups in the Delaware Estuary. Limnology and Oceanography, v. 50, p. 1697-1706, 2005.

KIRCHMAN, D.L. Introduction and overview. In: KIRCHMAN, D.L. (Ed.). Microbial Ecology of the Oceans. 2nd ed. New Jersey: Wiley-Blackwell, 2008. p. 1-26.

KONSTANTINIDIS, K.T.; RAMETTE, A.; TIEDJE, L.M. The bacterial species definition in the genomic era. Philosophical Transactions of the Royal Society B, v. 361, p. 1929-1940, 2006.

KOSDRÓJ, J.; van ELSAS, J.D. Structural diversity of microorganisms in chemically perturbed soil assessed by molecular and cytochemical approach. Journal of Microbiological Methods, v. 43, p. 197-212, 2001.

KUSKE, C.R.; BARNS, S.M.; BUSCH, J.D. Diverse uncultivated bacterial groups from soils of the arid southwestern United States that are present in many geographic regions. Applied and Environmental Microbiology, v. 63, p. 3614-362, 1997.

LaFRENTZ, B.R.; LaPATRA, S.E.; JONES, G.R.; CAIN, K.D. Protective immunity in rainbow trout Oncorhynchus mykiss following immunization with distinct molecular mass fractions isolated from Flavobacterium psychrophylum. Diseases of Aquatic Organisms, v. 59, p. 17-26, 2004. 
LANE, D. J. 16S/23S rRNA sequencing. In: STACKEBRANDT, E. e OODFELLOW, M. (Ed.). Nucleic acid techniques in bacterial systematics. England: John Wiley \& Sons, Chichester, 1991. p. 115-163.

LEANDRO, R.P. Climatologia das Águas do Canal de São Sebastião (SP). 162 f. Dissertação (Mestrado) - Instituto Oceanográfico, Universidade de São Paulo, São Paulo, 1999.

LEE, K.; LIU, C.; ANZAI, Y.; KIM, H.; AONO, T.; OYAIZU, H. The hierarchical system of the Alphaproteobacteria: description of Hyphomonadaceae fam. nov., Xanthobacteraceae fam. nov. and Erythrobacteraceae fam. nov. International Journal of Systematic and Evolutionary Microbiology, v. 55, p. 1907-1919, 2005.

LONGHURST, A. Ecological Geography of the Sea. San Diego: Academic Press, 1998.

LOREAU, M.; NAEEM, S.; INCHAUSTI, P.; BENGTSSON, J.; GRIME, J.P.; HECTOR, A.; HOOPER, D.U.; HUSTON, M.A.; RAFFAELLI, D.; SCHMID, B.; TILMAN, D.; WARDLE, D.A. Biodiversity and ecosystem functioning: current knowledge and future challenges. Science, v. 294, p. 804-808, 2001.

LOUWS, F.J.; SCHNEIDER, M.; de BRUIJN, F.J. Assessing genetic diversity of microbes using repetitive-sequence-based PCR (rep-PCR). In: TORANZOS, G. (Ed.) Nucleic Acid Amplifications Methods for the Analysis of Environmental Samples. Lancaster: Technomic Publishing Co., 1996. p. 63-94.

LOUWS, F.J.; RADEMAKER, J.L.W.; de BRUIJN, F.J. The three Ds of PCR-based genomic analysis of phytobacteria: diversity, detection, and disease diagnosis. Annual Review of Phytopathology, v. 37, p. 81-125, 1999.

LUDWIG, W.; BAUER, S.H.; BAUER, M.; HELD, I.; KIRCHHOF, G.; SCHULZE, R.; HUBER, I.; SPRING, S.; HARTMANN, A. \& SCHLEIFER. K.-H. Detection and in situ identification of representatives of a widely distributed new bacterial phylum. FEMS Microbiology Letters, v. 153, p. 181-190, 1997.

LUPSKI, J.R.; WEINSTOCK, G.M. Short, interspersed repetitive DNA sequences in prokaryotic genome. Journal of Bacteriology, v. 174, p. 4525-4529, 1992.

MACDONELL, M.T.; COLWELL, R.R. Phylogeny of the family Vibrionaceae and recommendations for two new genera: Listonella and Shewanella. Systematic and Applied Microbiology, v. 6, p.171-182, 1985. 
MADIGAN, M.T.; MARTINKO, J.M. Brock biology of microorganisms. 11th ed. Upper Saddle River: Pearson Prentice Hall, 2006.

MAGURRAN, E.E. Ecologycal diversity and its measurement. New Jersey: Princenton University Press, 1988. 177 p.

MANZ, W.; AMANN, R.; LUDWIG, W.; WAGNER, M.; SCHEIFER, K-H. Phylogenetic oligodeoxynucleotide probes for the major subclasses of proteobacteria: problems and solutions. Systematic and Applied Microbiology, v. 15, p. 593-600, 1992.

MAGURRAN, A.E. Ecological diversity and its measurement. Princeton: Princeton University Press, 1988.

MARKMAN, C.V. Caracterização de Vibrio cholerae, $V$. parahaemolyticus e $V$. vulnificus em amostras da região costeira do estado de São Paulo, de regiões portuárias brasileiras e de tanques de lastro de navios. 192 f. Tese (Doutorado em Ciências) - Instituto de ciências Biomédicas, Universidade de São Paulo, São Paulo, 2008.

MARSHALL, S.; CLARK, C.G.; WANG, G.; MULVEY, M.; KELLY, M.T.; JOHNSON. W.M. Comparison of molecular methods for typing Vibrio parahaemolyticus. Journal of Clinical Microbiology, v. 37, p. 2473-2478, 1999.

MARTINY, J.B.H.; BOHANNAN, B.J.M.; BROWN, J.H.; COLWELL, R.K.; FUHRMAN, J.A.; GREEN, J.L.; HORNER-DEVINE, M. C.; KANE, M.; KRUMINS, J.A.; KUSKE, C.R.; MORIN, P.J.; NAEEM, S.; ØVREÅS, L.; REYSENBACH, A.N.; SMITH, V.H; STALEY, J.T. Microbial biogeography: putting microorganisms on the map. Nature Reviews Microbiology, v. 4, p. 102-112, 2006.

McCAIG, A.E.; GLOVER, L.A.; PROSSER, J.I. Molecular analysis of eubacterial community structure and diversity in unimproved and improved upland grass pastures. Applied and Environmental Microbiology, v. 65, p. 1721-1730, 1999.

MEIBOM, K.L.; BLOKESCH, M.; DOLGANOV, N. A.; WU, C.; SCHOOLNIK, G. K. Chitin Induces Natural Competence in Vibrio cholerae. Science, v. 310, n. 5755, p. 1824 1827, 2005.

MENDES, F.M. Estrutura da comunidade macrozoobentônica na região de influência do Terminal Almirante Barroso (TEBAR) no Canal de São Sebastião (SP, Brasil). 75 f. Dissertação (Mestrado em Oceanografia) - Instituto Oceanográfico, Universidade de São Paulo, São Paulo, 2007. 
METHE, B.A.; HIORNS, W.D.; ZEHR, J.P. Contrasts between marine and freshwater bacterial community composition: analyses of communities in lake George and six other Adirondack lakes. Limnology and Oceanography, v. 43, p. 368-374, 1998.

MIKHAILOV, V.V.; ROMANENKO, L.A.; IVANOVA, E.P. The genus Alteromonas and related proteobacteria. In: DWORKIN, M.; FALKOW, S.; ROSENBERG, E.; SCHLEIFER, K-H.; STACKEBRANDT, E. (Ed.). The Prokaryotes. 3nd ed. New York: Springer, 2006. v. 6. p. $597-545$

MING, X.; HUA-QUN, Y.; YI, L.; JIE, L.; XUE-DUAN, L. Repetitive sequence based polymerase chain reaction to differentiate close bacteria strains in acidic sites. Transactions of Nonferrous Metals Society of China, v. 18, p. 1392-1397, 2008.

MIRANDA, L.B. Análise de massas de água da plataforma continental e da região oceânica adjacente: Cabo de São Tomé (RJ) e Ilha de São Sebastião (SP). 123 f. Tese de Livre-Docência - Instituto Oceanográfico, Universidade de São Paulo, São Paulo, 1982.

MOTER, A.; GOBEL, U.B. Fluorescence in situ hybridization (FISH) for direct visualization of microorganisms. Journal Microbiological Methods, v. 41, p. 85- 112, 2000.

MOORE, E.R.B.; TINDALL, B.J.; MARTINS DOS SANTOS, V.A.P.; PIEPER, D.H.; RAMOS, J.-L.; PALLERONI, N.J. Nonmedical: Pseudomonas. In: DWORKIN, M.; FALKOW, S.; ROSENBERG, E.; SCHLEIFER, K-H.; STACKEBRANDT, E. (Ed.). The Prokaryotes. 3nd ed. New York: Springer, 2006. v. 6., p. 646-703

MORIN, P.J. Community Ecology. Malden, MA: Blackwell Science, 1999.

MORRIS, C.E.; BARDIN, M.; BERGE, O.; FREY-KLETT, P.; FROMIN, N.; GIRARDIN, H.; GUINEBRETIE'RE, M.-H.; LEBARON, P.; THIE`RY, J.-M.; TROUSSELLIER, M. Microbial biodiversity: approaches to experimental design and hypothesis testing in primary scientific literature from 1975 to 1999. Microbiology and Molecular Biology Reviews, v. 66, p. 592-616, 2002.

MULHOLLAND, M.R.; GOBLER, C.J.; LEE, C. Peptide hydrolysis, amino acid oxidation, and nitrogen untake in communities seasonally dominated by Aureococcus anophagefferens. Limnology and Oceanography, v. 47, p. 1094-1108, 2002. 
MULLINS, T.D.; BRITSCHGI, T.B.; KREST, R.L.; GIOVANONNI, S.J. Genetic comparisons reveal the same Unknown bacterial lineages in Atlantic and Pacific bacteriplankton communities. Limnology and Oceanography, v. 40, p. 148-158, 1995.

NEE, S. Unveiling prokaryotic diversity. TRENDS in Ecology and Evolution, v. 18, p. 6263, 2003.

NEE, S. More than meets the eye. Nature, v. 429, p. 804-805, 2004.

NEEFS, J-M.; Van de PEER, Y.; HENDRIKS, L.; WACHTER, R de. Compilation of small ribosomal subunit RNA sequences. Nucleic Acids Research, v. 18, p. 2237-2330, 1990.

NICK, G.; JUSILLA, M.; HOSTE, B.; NIEMI, R.M.; KAIJALAINEN, S.; de LAJUDIE, R.; GILLIS, M.; de BRUIJN, F.J.; LINDSTRÖM, K. Rhizobia isolated from root nodules of tropical leguminous trees characterized using DNA-DNA dotblot hybridization and rep-PCR genomic fingerprinting. Systematic and Applied Microbiology, v. 22, p. 287-299, 1999.

NOGI, Y.; MASUI, N.; KATO, C. Photobacterium profundum sp. nov., a new, moderately barophilic bacterial species isolated from a deep-sea sediment. Extremophiles, v. 2, p. 1-7, 1998.

NUBEL, U.; ENGELEN, B.; FELSKE, A.; SNAIDR, J.; WIESHUBER, A.; AMANN, R.I.; LUDWIG, W.; BACKHAUS, H. Sequence Heterogeneities of Genes Encoding 16S rRNAs in Paenibacillus polymyxa Detected by Temperature Gradient Gel Electrophoresis. Journal of Bacteriology, v. 178, n.19, p. 5636-5643, 1996.

OLIVEIRA, V.M.; MANFIO, G.P.; COUTINHO, H.L.C.; KEIJZER-WOLTERS, A.C.; van ELSAS, J.D. A ribosomal RNA gene intergenic spacer based PCR and DGGE fingerprinting method for the analysis of specific rhizobial communities in soil. Journal of Microbiological Methods, v. 64, p. 366-379, 2006a.

OLIVEIRA, S.S.; WASIELESKY, J.R.W.; BALLESTER, E.L.C.; ABREU, P.C. Caracterização da assembléia de bactérias nitrificantes pelo método "Fluorescent In Situ Hybridization" (FISH) no biofilme e água de larvicultura do camarão-rosa Farfantepenaeus paulensis. Atlântica, v. 28, n. 1, p. 33-45, 2006 b.

OLIVER, J.D. Problems in detecting dormant (VBNC) cells and the role of DNA elements in this response. In: JANSSON, J.K.; van ELSAS, J.D.; BAILEY, M.J. (Ed.). Tracking Genetically-Engineered Microorganisms. Austin, Tex: Eurekah, 2000. p. 1-15. 
OLSEN, G.J.; LANE, D.J.; GIOVANNONI, S.J.; PACE, N.R.; STAHL, D.A. Microbial ecology and evolution: a ribosomal rRNA approach. Annual Review of Microbiology, v. 40, p. 337-365, 1986.

OLSEN, G.J.; WOESE, C.R. Ribosomal RNA: a key to phylogeny. The FASEB Journal, v. 7, p. 113-123, 1993.

ORTIGOSA, M.; ESTEVE, C.; PUJALTE, M.J. Vibrio species in seawater and mussels: abundance and numerical taxonomy. Systematic and Applied Microbiology, v. 12, p. 316$325,1989$.

ORTIGOSA, M.; GARAY, E.; PUJALT, M.J. Numerical taxonomy of Vibrionaceae isolated from oyster and seawater along an annual cycle. Systematic and Applied Microbiology, v. 17. p. $216-225,1994$.

PACE, N.R.; STAHL, D.A.; LANE, D.L.; OLSEN, G.J. The analysis of natural microbial populations by rRNA sequences. Advances in Microbial Ecology, v. 9, p. 1-55, 1986.

PACE, N.R. A molecular view of microbial diversity and the biosphere. Science, v. 276, p. 734-740, 1997.

PALLERONI, N.J. Present situation of the taxonomy of aerobic pseudomonads. In: GALLI, E.;SILVER, S.; WITHOLT, B. (Ed.). Pseudomonas: molecular biology and biotechnology. Washington, D.C.: ASM Press, 1992. p. 105-115.

PARK, Y-D.; BAIK, K.S.; SEONG, C.N.; BAE, K.S.; KIM, S.; CHUN, J. Photobacterium ganghwense sp. nov., a halophilic bacterium isolated from sea water. International Journal of Systematic and Evolutionary Microbiology, v. 56, p. 745-749, 2006.

PARKES, R.J.; GIBSON, G.R.; MUELLER-HARVEY, I.; BUCKINGHAM, W.J.; HERBERT, R.A. Determination of the substrates for sulphate-reducing bacteria within marine and esturaine sediments with different rates of sulphate reduction. Journal of General Microbiology, v. 135, p. 175-187, 1989.

PATEL, J.B.; LEONARD, D.G.; PAN, X.; MUSSER, J.M.; BERMAN, R.E.; NACHAMKIN, I. Sequence-based identification of Mycobacterium species using the MicroSeq 500 16S rDNA bacterial identification system. Journal Clinical Microbiology, v. 38, p. 246-251, 2000. 
PATRICK, F.M. The use of membrane filtration and Marine Agar 2216E to enumerate marine heterotrophic bacteria. Aquaculture, v. 13, p. 369-372, 1978.

PERNTHALER, J.; PERNTHALER, A.; AMANN, R. Automated enumeration of groups of marine picoplankton after Fluorescence In Situ Hybridization. Applied and Environmental Microbiology, v. 69, p. 2631-2637, 2003.

PIRES-VANIN, A. M. S. P.; CORBISIER, T. N.; ARASAKI, E.; MOELLMANN, A. M. Composição e distribuição espaço temporal da fauna bêntica no Canal de São Sebastião. Relatório Técnico do Instituto Oceanográfico, v. 41, p. 29-46, 1997.

POMEROY, L.R. Oceans food web, a changing paradigm. Bioscience, v. 24, p. 499-504, 1974.

POMEROY, L.R.; WILLIANS, P.J. Le B.; AZAM, F.; HOBBIE, J.E. The Microbial Loop. Oceanography, v. 20, p. 28-33, 2007.

PORTER, K.G.; FEIG, Y.S. The use of DAPI for identifying and counting aquatic microflora. Limnology and Oceanography, v. 25, p. 943-948, 1980.

PRIEST, F.G. Isolation and identification of aerobic endospore-forming bacteria. In: HARWOOD, C.R. (ed.). Bacillus. New York: Plenum Press, 1989. p. 27-56.

PROSSER, J.I.; BOHANNAN, B.J.M.; CURTIS, T.P.; ELLIS, R.J.; FIRESTONE, M.K.; FRECKLETON, R.P.; GREEN, J.L.; GREEN, L.E.; KILLHAM, K.; LENNON, J.J; OSBORN, A.M.; SOLAN, M.; GAST, C.J. van der; YOUNG, J.P.W. The role of ecological theory in microbial ecology. Nature Reviews Microbiology, v. 5, p. 384-392, 2007.

RADEMAKER, J.L.W.; de BRUIJN, F.J. Characterization and classification microbes by repPCR genomic fingerprinting and computer assisted pattern analysis. In: CAETANOANOLLÉS, G.; GRESSHOFF, P.M. (Ed.). DNA Markes: protocols, applications and overviews. New York: J. Wiley \& Sons, 1997. p. 151-171

RADEMAKER, J.L.W.; HOSTE, B.; LOUWS, F.J.; KERSTERS, K.; SWINGS, J.; VAUTERIN, L.; VAUTERIN, P.; de BRUJIN, F.J. Comparison of AFLP and rep-PCR genomic fingerprinting with DNA-DNA homology studies: Xanthomonas as a model system. International Journal of Systematic Bacteriology, v. 50, p. 665-677, 2000.

RADEMAKER, J.L.W.; SAVELKOUL, P.H.M. PCR amplification based microbial typing. In: PERSHING, D.H.; TENOVER, F.C.; VERSALOVIC, J.; TANG, Y.W.; UNGER, E.R.; 
RELMAN, D.A.; WHITE, T.J. (Ed.). Diagnostic Molecular Microbiology Principles and Applications. Washington, D.C.: ASM Press, 2004. p. 197-221.

RADEMAKER, J.L.W.; AARTS, H.; VINUESA, P. Molecular typing of environmental isolates. In: OSBORN, M. (Ed.). Molecular Microbial Ecology. Oxfordshire: Bios Scientific Publishers, 2004a. Chapter 4

RADEMAKER, J.L.W.; LOUWS, F.L.; VERSALOVIC, J.; de BRUIJN, F.J. Characterization of the diversity of ecologically important microbes by rep-PCR genomic fingerprinting. In: KOWALCHUK, G.A.; de BRUIJN, F.J.; HEAD, I.M.; AKKERMANS, A.D.L.; van ELSAS, J.D. (Ed.). Molecular Microbial Ecology Manual. Kluwer Academic Publishers, 2004b. v. 1, p. 611-644.

RAHN, O. New principles for the classification of bacteria. Zbl. Bakt., II Abt , v. 96, p. 273286, 1937.

RAPPÉ, M. S.; KEMP, P.F.; GIOVANNONI, S.J. Phylogenetic diversity of marine coastal picoplankton 16S rRNA genes cloned from the continental shelf off Cape Hatteras, North Carolina. Limnology and Oceanography, v. 42, p. 811-826, 1997.

RASCHE, F.; HÖDL, V.; POLL, C.; KANDELER, E.; GERZABEK, M.H.; VAN ELSAS, J. D.; SESSITSCH, A. Rhizosphere bacteria affected by transgenic potatoes with antibacterial activities compared with the effects of soil, wild-type potatoes, vegetation stage and pathogen exposure. FEMS Microbiology Ecology, v. 56, p. 219-235, 2006.

REHNSTAM, A.S.; BACKMAN, S.; SMITH, D.C.; AZAM, F.; HAGSTROM, A. Blooms of sequence-specific culturable bacteria in the sea. FEMS Microbiology Ecology, v. 102, p. 161-166, 1993.

REIS, A.M.M.; ARAÚJO JR, S.D.; MOURA, R.L.; FRANCINI-FILHO, R.B.; PAPPAS JR, G.; COELHO, A.M.A.; KRÜGER, R.H.; THOMPSON, F.L. Bacterial diversity associated with the Brazilian endemic reef coral Mussismilia braziliensis. Journal of Applied Microbiology, v. 106, p. 1378-1387, 2009.

RIBEIRO, S.M.M.S. Caracterização taxonômica e ecológica das comunidades pico-, nano- e microplanctônicas, superficial e profunda da zona eufótica do Atlântico Sul. Tese (Doutorado em Oceanografia) - Instituto Oceanográfico, Universidade de São Paulo, São Paulo, 1996. 
RICHARDS, G.P; WATSON, M.A.; CRANE III,, E.J.; BURT, I.G.; BUSHEK, D. Shewanella and Photobacterium spp. in Oysters and Seawater from the Delaware Bay. Applied and Environmental Microbiology, v. 74, p. 3323-3327, 2008.

RIVERA, I.N.G.; LIPP, E.K.; GIL, A.; CHOOPUN, N.; HUQ, A.; COLWELL, R.R. Method of DNA extraction and application of multiplex polymerase chain reaction to detect toxigenic Vibrio cholerae O1 and O139 from aquatic ecosystems. Environmental Microbiology, v. 5, p. 599-606, 2003.

RODICIO, M.R.; MENDOZA, M.C. Identificación bacteriana mediante secuenciación del ARNr 16S: fundamento, metodología y aplicaciones en microbiologia clínica. Enfermedades Infecciosas y Microbiología Clínica, v. 22, p. 238-245, 2004.

RODRIGUES, D.F.; SAKATA, S.K.; COMASSETO, J.V.; BÍCEGO, M.C.; PELLIZARI, V.H. Diversity of hydrocarbon-degrading Klebsiella strains isolated from hydrocarboncontaminated estuaries. Journal of Applied Microbiology, v. 106, 1304-1314, 2009.

RODRIGUEZ, F.; DERELLE, E.; GUILLOU, L.; GALL, F. Le; VAULOT, D.; MOREAU, H. Ecotype diversity in the marine picoeukaryote Ostreococcus (Chlorophyta, Prasinophyceae). Environmental Microbiology, v. 7, p. 853-859, 2005.

RODRIGUEZ-VALERA, F. Environmental genomics, the big picture? FEMS Microbiology Letters, v. 231, p. 153-158, 2004.

ROLLER, C.; WAGNER, M.; AMANN, R.; LUDWIG, W.; SCHLEIFER, K.H. In situ probing of gram-positive bacteria with high DNA G1C content using 23S ribosomal-RNAtargeted oligonucleotides. Microbiology, v. 140, p. 2849-2858, 1994.

ROSADO, A. S.; DUARTE, G.F.; SELDIN, L.; ELSAS, J.D.van. Molecular microbial ecology: a minireview. Revista de Microbiologia, v. 28, p. 135-147, 1997.

ROSSELLÓ-MORA, R.; AMANN, R. The species concept for prokaryotes. FEMS Microbiology Reviews, v. 25, p. 36-67, 2001.

ROSSELLÓ-MORA, R.; KÄMPFER, P. Defining Microbial Diversity - the species concept for prokaryotic and eukaryotic microorganisms. In: BULL, A.T. (Ed.). Microbial Diversity and Bioprospecting. Washington, D.C.: ASM Press, 2004. p. 29-39. 
ROSZACK, D.B.; GRIMES, D.J.; COLWELL, R.R. Viable but non recoverable stage of Salmonella enteritidis in aquatic system. Canadian Journal of Microbiology, v. 30, p. 334338, 1984.

ROSZACK, D.B.; COLWELL, R.E. Survival strategies of bacteria in the natural environment. Microbiological Reviews, v. 51, p. 365-379, 1987.

RUBIN, A. Pesquisa de Vibrio cholerae na água do mar e zooplâncton na região costeira de São Sebastião, Litoral Norte do Estado de São Paulo. Dissertação (Mestrado em Microbiologia) - Instituto de Ciências Biomédicas, Universidade de São Paulo, São Paulo, 2000.

SAHM, K.; KNOBLAUCH, C.; AMANN, R. Phylogenetic affiliation and qualification psychorophilic sulphate-reducing isolates in marine arctic sediments. Applied and Environmental Microbiology, v. 65, p. 3976-3981, 1999.

SAIT, L.; GALIC, M.; STRUGNELL, R.A.; JANSSEN. P.H. Secretory antibodies do not affect the composition of bacterial microbiota in the terminal ileum of 10 -week-old mice. Applied and Environmental Microbiology, v. 69, p. 2100-2109, 2003.

SAITOU, N.; NEI, M. The neighbor-joining method: a new method for reconstructing phylogenetic trees. Molecular Biology and Evolution, v. 4, p. 406-425, 1987.

SAMBROOK, J.; RUSSELL, D.W. Molecular cloning: a laboratory manual. New York: Cold Spring Harbor Press, 2001.

SANGER, F.; NICKLEN, S.; COULSON, A.R. DNA sequencing with chain-terminating inhibitors. Proceedings of the National Academy of Sciences of the United States of America, v. 74, p. 5463-5467, 1977.

SANZ, J.L.; KÖCHLING, T. Molecular biology techniques used in wastewater treatment: an overview. Process Biochemistry, v. 42, p. 119-133, 2007.

SAWABE, T.; THOMPSON, F.L.; HEYRMAN, J.; CNOCKAERT, M.; HAYASHI, K.; TANAKA, R.; YOSHIMIZU, M.; HOSTE, B.; SWINGS, J.; EZURA, Y. Fluorescent Amplified Fragment Length Polymorphism and Repetitive Extragenic Palindrome-PCR fingerprinting reveal host-specific genetic diversity of Vibrio halioticoli-Like strains isolated from the gut of Japanese Abalone. Applied and Environmental Microbiology, v. 68, p. 4140-4144, 2002. 
SCHLOSS, P.D.; HANDELSMAN, J. Status of the microbial census. Microbiology and Molecular Biology Reviews, v. 68, p. 686-691, 2004.

SCHLOSS, P.D.; HANDELSMAN, J. Introducing DOTUR, a computer program for defining Operational Taxonomic Units and estimating species richness. Applied and Environmental Microbiology, v. 71, p. 1501-1506, 2005.

SCHLOSS, P.D.; HANDELSMAN, J. Toward a census of bacteria in soil. PLOS Computational Biology, .v 2, p. 786-787, 2006.

SCHMIDT, T.M.; DELONG, E.F.; PACE, N.R. Analysis of a marine picoplankton community by $16 \mathrm{~S}$ rRNA gene cloning and sequencing. Journal of Bacteriology, v. 173, p. 4371-4378, 1991.

SCHROLL, G.; PARRER, G.; BUSSE, H.-J.; RÖLLEKE, S.; LUBITZ, W.; DENNER, E.B.M. Alcaligenes faecalis subsp. parafaecalis subsp. nov., a bacterium accumulating poly$\beta$-hydroxybutyrate on acetone-butanol containing bioprocess residues. Systematic and Applied Microbiology, v. 24, p. 37-43, 2001.

SCHROTH, M.; HILDEBRAND, D.C; PANOPOULOS, N. Phytopathogenic pseudomanads and plant -associated pseudomonads . In: BALOWS, A.; TRÜPER, H.G.; DWORKIN, M.; HARDER, W.; SCHLEIFER, K.H. The Prokaryotes. 2nd ed. New York: Springer-Verlag, 1992. v.3, p. 3104-3131

SCHUT, F.; DE VRIES, E.J.; GOTITSCHAL, J.C.; ROBERTSON, B.R.; HARDER, W.; PRINS, R.A.; BUTTON, D.K. Isolation of typical marine bacteria by dilution culture: growth, maintenance, and characteristics of isolates under laboratory conditions. Applied and Environmental Microbiology, v. 59, p. 2150-2160, 1993.

SEKAR, R.; FUCHS, B.M.; AMANN, R.; PERNTHALER, J. Flow sorting of marine bacterioplankton after fluoresence in situ hybridization. Applied and Environmental Microbiology, v. 70, p. 6210-6219, 2004.

SEKI, H. Seasonal fluctuation of heterotrophic bacteria in the sea of Aburatsubo inlet. The Journal of the Oceanographical Society of Japan, v. 22, p. 93-104, 1966.

SHANGKUAN, Y.H.; TSAO, C.M.; LIN. H.C. Comparison of Vibrio cholerae O1 isolates by polymerase chain reaction fingerprinting and ribotyping. Journal of Medical Microbiology, v. 46, p. 941-948, 1997. 
SIERACKI, M.E.; JOHNSON, P.W.; SIEBURTH, J.M. Detection, enumeration, and sizing of planktonic bacteria by image-analyzed epifluorescence microscopy. Applied and Environmental Microbiology, v. 49, p. 799-810, 1985.

SILVA, L. S. Estudo numérico da circulação e da estrutura termohalina no Canal de São Sebastião. 256 f. Tese (Doutorado em Oceanografia) - Instituto Oceanográfico, Universidade de São Paulo, São Paulo, 2001.

SILVA, L.S.; MIRANDA, L.B.; CASTRO FILHO, B.M. Numerical study of circulation and thermohaline structure in the São Sebastião Channel. Revista Brasileira de Geofísica, v. 23 n. 4, p. 407-425, 2005.

SMALLA, K. Culture-Independent Microbiology. In: BULL, A.T. (Ed.). Microbial Diversity and Bioprospecting. Washington, D.C.: ASM Press, 2004. p. 88-99

SOGIN, M.L.; MORRISON, H.G.; HUBER, J.A.; WELCH, D.M.; HUSE, S.M.; NEAL, P.R.; ARRIETA, J.M.; HERNDI, G.J. Microbial diversity in the deep sea and the underexplored "rare biosphere". The Proceedings of the National Academy of Science USA, v. 103, p. 12115-12120, 2006.

SOUZA, K.M.C. Qualidade microbiológica de água de lastro de navios, água e bivalves da região portuária brasileira, com ênfase na detecção de Vibrio cholerae O1. 198 f. Tese (Doutorado em Ciências) - Instituto de ciências Biomédicas, Universidade de São Paulo, São Paulo, 2007.

SOUZA, C.P. Diversidade de bactérias quitinolíticas isoladas em amostras de água do mar e plâncton coletadas na região costeira do estado de São Paulo. 205 f. Tese (Doutorado em Ciências) - Instituto de ciências Biomédicas, Universidade de São Paulo, São Paulo, 2009.

STACH, J. E. M. e BULL. A. T. Estimating and comparing the diversity of marine actinobacteria. Antonie Leeuwenhoek, v. 87, p. 3-9, 2005.

STACKEBRANDT, E.; MURRAY, R.G.E.; TRUPER, H.G. Proteobacteria classis nov., a name for the phylogenetic taxon that includes the "purple bacteria and their relatives". International Journal of Systematic Bacteriology, v. 38, p. 321-325, 1988.

STACKEBRANDT, E.; GÖBEL, B.M. Taxonomic note: a place for DNA-DNA reassociation and 16S rRNA sequences analysis in the present species definition in bacteriology. International Journal of Systematic Bacteriology, v. 44, p. 846-849, 1994. 
STAHL, D.A.; FLESHER, B.; MANSFIELD, H.R.; MONTGOMERY, L. Use of phylogenetically based hybridization probes for studies of ruminal microbial ecology. Applied and Environmental Microbiology, v. 54, p. 1079-1084, 1988.

STALEY, J.T.; GOSINK, J.J. Poles apart: biodiversity and biogeography of sea ice bacteria. Annual Review of Microbiology, v.53, p. 189-215, 1999.

STALEY, J.T.; KONOPKA, A. Measurement in situ activities of nonphotosynthetic microorganisms aquatic and terrestrial habitats. Annual Review of Microbiology, v. 39, p. 321-346, 1985.

STANIER, R. Y.; NIEL, C. B. van. The concept of a bacterium. Archives of Microbiology, v. 42, p. 17-35, 1962.

STANIER, R. Y.; DOUDOROFF, M.; ADELBERG, E. A. The Microbial World. 2nd ed. Engelwood Cliffs: Prentice-Hall, 1963.

STEELE, J. The Structure of Marine Ecosystems. Massachusetts: Harvard Univ. Press, 1974.

STEVENSON, B.S.; EICHORST, S.A.; WERTZ, J.T.; SCHMIDT, T.M.; BREZNAK, J.A. New strategies for cultivation and detection of previously uncultured microbes. Applied and Environmental Microbiology, v. 70, p. 4748-4755, 2004.

STREIT, W.R.; SCHMITZ, R.A. Metagenomics - the key to the uncultured microbes. Current Opinion in Microbiology, v. 7, p. 492-498, 2004.

TAKII, S.; HANADA, S.; HASE, Y.; TAMAKI, H.; UYENO, Y.; SEKIGUCHI, Y.; MATSUURA, K. Desulfovibrio marinisediminis sp. nov., a novel sulfate-reducing bacterium isolated from coastal marine sediment via enrichment with Casamino acids. International Journal of Systematic and Evolutionary Microbiology, v. 58, p.2433-2438, 2008.

TAMURA, K.; DUDLEY, J.; NEI, M.; KUMAR, S. MEGA 4: molecular evolutionary genetics analysis (MEGA) software version 4.0. Molecular Biology and Evolution, v. 24, p. 1596-1599, 2007.

TEMPLETON, A.R. The meaning of species and speciation: a genetic perspective. In: OTTE, D. e ENDLER, J.A. (Ed.). Speciation and its consequences. Sunderland, MA: Sinauer Associates, 1989. 
THOMPSON, F.L.; HOSTE, B.; VANDEMEULEBROECKE, K.; SWINGS, J. Genomic diversity amongst Vibrio isolates from different sources determined by fluorescent amplified fragment length polymorphism. Systematic and Applied Microbiology, v. 24, p. 520-538, 2001.

THOMPSON, F.L.; IIDA, T.; SWINGS, J. Biodiversity of vibrios. Microbiology and Molecular Biology Reviews, v. 68, p. 403-431, 2004.

THOMPSON, F.L.; GEVERS, D.; THOMPSON, C.C.; DAWYNDT, P.; NASER, S.; HOSTE, B.; MUNN, C.B.; SWINGS, J. Phylogeny and molecular identification of Vibrios on the basis of multilocus sequence analysis. Applied and Environmental Microbiology, v. 71, p. 5107-5115, 2005a.

THOMPSON, F.L.; THOMPSON, C.C.; NASER, S.; HOSTE, B.; VANDEMEULEBROECKE, K.; MUNN, C.; BOURNE, D.; SWINGS, J. Photobacterium rosenbergii sp. nov. and Enterovibrio coralii sp. nov., vibrios associated with coral bleaching. International Journal of Systematic and Evolutionary Microbiology, v. 55, p. 913-917, 2005b.

THOMPSON, F.L.; SWINGS, J. Taxonomy of Vibrios. In: THOMPSON, F.L.; AUSTIN, B.; SWINGS, J. The Biology of Vibrios. Washington, D.C.: ASM Press, 2006. p. 29-43

THOMPSON, C.C.; THOMPSON, F.L.; VICENTE, A.C.P.; SWINGS, J. Phylogenetic analysis of vibrios and related species by means of atpA gene sequences. International Journal of Systematic and Evolutionary Microbiology, v. 57, p. 2480-2484, 2007.

TORSVIK, V.; ØVREÅS, L. Microbial diversity and function in soil: from genes to ecosystems. Current Opinion in Microbiology, v. 5, p. 240-245, 2002.

TORSVIK, V.; ØVREÅS, L.; THINGSTAD, T.F. Prokaryotic diversity - magnitude, dynamics, and controlling factors. Science, v. 296, p. 1064-1066, 2002.

TRINGE, S.G.; VON MERING, C.; KOBAYASHI, A.; SALAMOV, A.A.; CHEN, K.; CHANG, H.W.; PODAR, M.; SHORT, J.M.; MATHUR, E.J.; DETTER, J.C.; BORK, P.; HUGENHOLTZ, P.; RUBIN, E.M. Comparative metagenomics of microbial communities. Science, v. 308, p. 554-557, 2005.

TYSON, G.W.; BANFIELD, J.F. Cultivating the uncultivated: a community genomics perspective. TRENDS in Microbiology, v.13, p. 411-415, 2005. 
URAKAWA, H.; YOSHIDA, T.; NISHIMURA, M.; OHWADA, K. Characterization of depth- related population variation in microbial communities of a coastal marine sediment using 16S rDNA-based approaches and quinine profiling. Environmental Microbiology, v. 2 , p. $542-554,2000$.

van ELSAS, J.D.; DUARTE, G.F.; ROSADO, A.S.; SMALLA, K. Microbiological and molecular methods for monitoring microbial inoculants and their effects in the soil environmental. Journal of Microbiological Methods. v. 32, p. 133-154, 1998.

van SPANNING, R.J.M. ; STOUTHAMER, A.H. ; BAKER, S.C. ; van VERSEVELD, H.W. Genus IV: Paracoccus. Bergey's Manual ${ }^{\circledR}$ of Systematic Bacteriology. 2nd Ed. East Lansing: Springer, 2005. v. 2, Part C. p. 197-204.

VANDAMME, P.; POT, B.; GILLIS, M. ; de VOS, P.; KERSTERS, K.; SWINGS, J. Polyphasic taxonomy, a consensus approach to bacterial systematics. Microbial Reviews, v. 60, p. 407-438, 1996.

VENKATESWARAN, K.; MOSER, D.P.; DOLLHOPF, M.E.; LIES, D.P.; SAFFARINI, D.A.; MACGREGOR, B.J.; RINGELBERG, D.B.; WHITE, D.C.; NISHIJIMA, M.; SANO, H.; BERGHARDT, J.; STACKEBRANDT, E.; NEALSON, K.H. Polyphasic taxonomy of the genus Shewanella and description of Shewanella oneidensis sp. nov. International Journal of Systematic Bacteriology, v. 49, p. 705-724, 1999.

VENTER, J.C.; REMINGTON, K.; HEIDELBERG, J.F.; HALPERN, A.L.; RUSCH, D.; EISEN, J.A.; WU, D.; PAULSEN, I.; NELSON, K.E.; NELSON, W.; FOUTS, D.E.; LEVY, S.; KNAP, A.H.; LOMAS, M.W.; NEALSON, K; WHITE, O.; PETERSON, J.; HOFFMAN, J.; PARSONS, R.; BADEN-TILLSON, H.; PFANNKOCH, C.; ROGERS, Y-H.; SMITH, H.O. Environmental genome shotgun sequencing of the Sargasso Sea. Science, v. 304, p. 6674, 2004.

VENTURINI, N. Influência da quantidade e qualidade da matéria orgânica sedimentar na estrutura e distribuição vertical e horizontal das comunidades bentônicas na plataforma de São Sebastião, São Paulo, Brasil. 230 f. Tese (Doutorado em Oceanografia) - Instituto Oceanográfico, Universidade de São Paulo, São Paulo, 2007.

VERSALOVIC, J.; KOEUTH, T.; LUPSKI, J.R. Distribution of repetitive DNA sequences in eubacteria and application to fingerprinting of bacterial genomes. Nucleic Acids Research, v. 19, p. 6823-6831, 1991. 
VERSALOVIC, J.; SCHNEIDER, M.; de BRUIJN, F.J.; LUPSKI, J.R. Genomic fingerprinting of bacteria using repetitive sequence based PCR (rep-PCR). Methods in Cellular and Molecular Biology, v. 5, p. 25-40, 1994.

VERSALOVIC, J.; de BRUIJN, F.J.; LUPSKI, J.R. Repetitive sequence-based PCR (repPCR) DNA fingerprinting of bacterial genomes. In: de BRUIJN, F.J.; LUPSKI, J.R.; WEINSTOCK, G.M. (Ed.). Bacterial Genomes: physical structure and analysis. New York: Chapman and Hall, 1998. p. 437-454

Von der WEID, I.; KORENBLUM, E.; JURELEVICIUS1, D.; ROSADO, A.S.; DINO, R.; SEBASTIÁN, G.V.; SELDIN, L. Molecular diversity of bacterial communities from subseafloor rock samples in a deep-water production basin in Brazil. Journal of Microbiology and Biotechnology, v. 18, p. 5-14, 2008.

WARD, D.M.; WELLER, R.; BATESON, M.M. 16S rRNA sequences reveal numerous uncultured microorganisms in a natural community. Nature, v. 345, p. 63-65, 1990.

WARD, D.M. A natural species concept for prokaryotes. Current Opinion in Microbiology, v. 1, p. 271-277, 1998.

WEST, N.J.; SCHONHUBER, W.A.; FULLER, N.J.; AMANN, R.I.; RIPPKA, R.; POST, A.F.; SCANLAN, D.J. Closely related Prochlorococcus genotypes show remarkably different depth distributions in two oceanic regions as revealed by in situ hybridization using $16 \mathrm{~S}$ rRNA-targeted oligonucleotides. Microbiology, v. 147, p. 1731-1744, 2001.

WHITMAN, W.B.; COLEMAN, D.C.; WIEBE, W.J. Prokaryotes: the unseen majority. The Proceedings of the National Academy of Science USA, v. 95, p. 6578-6583, 1998.

WILLIAMS, P.J. le B. Microbial contribution to overall marine plankton metabolism: direct measurements of respiration. Oceanologica Acta, v. 4, p. 359-364, 1981a.

WILLIAMS, P.J. le B. Incorporation of microheterotrophic processes into the classical paradigm of the planktonic food web. Kiel Meeresforsch Sonderh, v. 5, p. 1-28, 1981 b.

WINFREY, M.R.; WARD, D.M. Substrates for Sulfate Reduction and Methane Production in Intertidal Sediments. Applied and Environmental Microbiology, v. 45, p. 193-199, 1983.

WOESE, C.R.; STACKEBRANDT, E.; MACKE, T.J.; FOX, G.E. A phylogenetic definition of the major eubacterial taxa. Systematic and Applied Microbiology, v. 6, p. 143-151, 1985. 
WOESE, C.R. Bacterial evolution. Microbiological Reviews, v. 51, p. 221-271, 1987.

WOESE, C.R.; KANDLER, O.; WHEELIS, M.L. Towards a natural system of organisms: proposal for the domains Archaea, Bacteria and Eukarya. The Proceedings of the National Academy of Science USA, v. 87, p. 4576-4579, 1990.

WOESE, C.R. There must be a prokaryote somewhere: microbiology's search for itself. Microbiological Reviews, v. 58, p. 1-9, 1994

WOESE, C. R. A new biology for a new century. Microbiology and Molecular Biology Reviews, v. 68, p. 173-186, 2004.

WONG, H.C.; LIN, C.H. Evaluation of typing of Vibrio parahaemolyticus by three PCR methods using specific primers. Journal of Clinical Microbiology, v. 9, p. 4233-4240, 2001.

WOODS, C.L.; VERSALOVIC, J.; KOEUTH, T.; LUPSKI, J.R. Whole-cell repetitive element sequence-based polymerase chain reaction allows rapid assessment of clonal relationships of bacterial isolates. Journal of Clinical Microbiology, v. 31, p. 1927-1931, 1993.

YANG, H.H.; VINOPAL, R.T.; GRASSO, D.; SMETS, B.F. High diversity among environmental Escherichia coli isolates from a bovine feedlot. Applied and Environmental Microbiology, v. 70, p. 1528-1536, 2004.

YOSHIZAWA, S.; WADA, M.; KITA-TSUKAMOTO, K.; YOKOTA, A.; KOGURE, K. Photobacterium aquimaris sp. nov., a luminous marine bacterium isolated from seawater. International Journal of Systematic and Evolutionary Microbiology, v. 59, p. 1438-1442, 2009.

ZACCONE, R.; CARUSO, G.; CALÍ, C. Heterotrophic bacteria in the northern Adriatic Sea: seasonal changes and ectoenzyme profile. Marine Environmental Research, v. 54, p. 1-19, 2002.

ZEIGLER, D.R. Gene sequences useful for predicting relatedness of whole genomes in bacteria. International Journal of Systematic and Evolutionary Microbiology, v. 53, p. 1893-1900, 2003. 
ZEMBRUSCKI, S.G. Geomorfologia da Margem Continental Sul Brasileira e das Bacias Oceânicas adjacentes (Relatório Final). In: CHAVES, H.A.F. (Ed.). Reconhecimento Global da Margem Continental Brasileira. Rio de Janeiro: Petrobrás, 1979. p. 129-177.

ZINDER, S.H.; SALYERS, A.A. Microbial Ecology - new directions, new importance. In: BRENNER, D.J.; KRIEG, N.R.; STALEY, J.T. Bergey's Manual ${ }^{\circledR}$ of Systematic Bacteriology. 2nd ed. East Lansing: Springer, 2005. v. 2, Part A.

ZO, G.; RIVERA, I.N.G.; RUSSEK-COHEN, E; ISLAM, M.S.; SIDDIQUE, A.K.; YUNUS, M.; SACK, R.B; HUQ, A.; COLWELL, R.R. Genomic profiles of clinical and environmental isolates of Vibrio cholerae $\mathrm{O} 1$ in cholera endemic areas of Bangladesh. Proceedings of the National Academy of Sciences of the United States of America, v. 99, n. 19, p. 1240912414, 2002.

ZOBELL, C.E. Studies on marine bacteria. 1. The cultural requirements of heterotrophic aerobes. Journal of Marine Research, v. 4, p. 42-75, 1941.

ZOBELL, C.E.; UPHAM, H.C. A list of marine bacteria including descriptions of sixty new species. Bulletin of the Scripps Institution of Oceanography, v. 5, p. 239-292, 1944.

ZOBELL, C.E. Marine microbiology: a monograph on hydrobacteriology. Waltham, MA: Chronica Botanica Co., 1946.

ZOBELL, C.E.; MORITA, R.Y. Barophilic bacteria in some deep sea sediments. The Journal of Bacteriology, v. 73, p. 563-568, 1957. 


\begin{abstract}
ANEXOS
ANEXO A - Reagentes utilizados nas metodologias empregadas.

\section{TAE 1X (Tris-Acetato-EDTA)}

Adicionar $20 \mathrm{~mL}$ de TAE 50X em 980 mL de água ultrapura.

TAE 50X: pesar $242 \mathrm{~g}$ de Tris e dissolver, por agitação, em $700 \mathrm{~mL}$ de água ultrapura. Uma vez dissolvido todo o Tris, adicionar nesta solução $57,1 \mathrm{~mL}$ de ácido acético glacial e $100 \mathrm{~mL}$ de EDTA 0,5 M (pH 8.0). Completar com água ultrapura até o volume de $1000 \mathrm{~mL}$, homogeneizar e conservar a temperatura ambiente.
\end{abstract}

2. Tampão TE 1M, pH 8.0 (Tris-EDTA, $10 \mathrm{mM}$ Tris-HCl, pH 8.0 e 1 mM EDTA, pH 8.0)

Adicionar $10 \mathrm{~mL}$ de solução estoque de Tris- $\mathrm{HCl} 1 \mathrm{M}$, pH 8.0 e $2 \mathrm{~mL}$ de solução estoque de EDTA 0.5 M, pH 8.0, para um volume de $1000 \mathrm{~mL}$ de água ultrapura.

3. Solução de hibridização [0,9 M de $\mathrm{NaCl}, 20 \mathrm{mM}$ de Tris-HCl (pH 7.2), $5 \mathrm{mM}$ de EDTA, 0,01\% de SDS, 30\% de formamida (sondas ALF1b, BET42a, GAM42a) e 20\% de formamida (sonda DELTA)]

Adicionar $180 \mathrm{~mL}$ de solução estoque de $\mathrm{NaCl}$ 5M, $20 \mathrm{~mL}$ de solução estoque de Tris$\mathrm{HCl} 1 \mathrm{M}, \mathrm{pH}$ 8.0, $10 \mathrm{~mL}$ de solução estoque de EDTA 0.5 M, $10 \mathrm{~mL}$ de SDS 1\%, 30\% de formamida (sondas ALF1b, BET42a, GAM42a) e 20\% de formamida (sonda DELTA) para um volume de $1000 \mathrm{~mL}$ de água ultrapura.

4. Solução de lavagem [102 mM de NaCl (sondas ALF1b, BET42a, GAM42a) e $308 \mathrm{mM}$ de $\mathrm{NaCl}$ (sonda DELTA), $20 \mathrm{mM}$ de Tris-HCl (pH 7.2), 5 mM de EDTA, 0,01\% de SDS]

Adicionar 20,4 mL de solução estoque de $\mathrm{NaCl} 5 \mathrm{M}$ (sondas ALF1b, BET42a, GAM42a) e 61,6 mL de solução estoque de $\mathrm{NaCl} 5 \mathrm{M}$ (sonda DELTA), $20 \mathrm{~mL}$ de solução 
estoque de Tris- $\mathrm{HCl}$ 1M, pH 8.0, 10 mL de solução estoque de EDTA 0.5 M, 10 mL de SDS $1 \%$ para um volume de $1000 \mathrm{~mL}$ de água ultrapura.

\section{5. Água de diluição}

Acrescentar 1,25 mL de solução estoque A e $5 \mathrm{~mL}$ de solução estoque B para um volume de $1000 \mathrm{~mL}$ de água destilada. Esta solução é autoclavada a $121^{\circ} \mathrm{C}$ por 15 minutos.

Solução estoque A: $34 \mathrm{~g}$ de fosfato monopotássico $\left(\mathrm{KH}_{2} \mathrm{PO}_{4}\right)$ são dissolvidos em 500 $\mathrm{mL}$ de água destilada. $\mathrm{O}$ pH é ajustado para 7,2 com solução de hidróxido de sódio $1 \mathrm{~N}$ e o volume é completado para $1000 \mathrm{~mL}$ com água destilada. Esta solução é esterilizada em autoclave a $121^{\circ} \mathrm{C}$ por 15 minutos e estocada em geladeira.

Solução estoque B: $81,1 \mathrm{~g}$ de cloreto de magnésio $\left(\mathrm{MgCl}_{2} \cdot \mathrm{H}_{2} \mathrm{O}\right)$ são dissolvidos em $500 \mathrm{~mL}$ de água destilada e o volume é completado para $1000 \mathrm{~mL}$ com água destilada. Esta solução é esterilizada em autoclave a $121^{\circ} \mathrm{C}$ por 15 minutos e estocada em geladeira.

\section{Tampão SET (Tampão Sacarose - EDTA - Tris-HCl)}

Preparado com $20 \%$ de sacarose, $100 \mathrm{~mL}$ de solução estoque de EDTA $0.5 \mathrm{M}$ e $50 \mathrm{~mL}$ de solução estoque de Tris- $\mathrm{HCl}$ 1M, pH 7,6 para um volume de $1000 \mathrm{~mL}$ de água ultrapura.

\section{Meio SOC}

Triptona (2 g), Extrato de Levedura (0,5 g), NaCl 1M (1 mL), KCl 1M (0,25 mL), Solução estoque de $\mathrm{Mg}^{2+} 2 \mathrm{M}(1 \mathrm{~mL})$, Solução estoque de glicose $2 \mathrm{M}(1 \mathrm{~mL}) \mathrm{em} 100 \mathrm{~mL}$ de água ultrapura.

Adicionar a Triptona, o Extrato de Levedura, o $\mathrm{NaCl}$ e o $\mathrm{KCl}$ a $90 \mathrm{~mL}$ de água ultrapura. Misturar e autoclavar a $121^{\circ} \mathrm{C}$ por 15 minutos. Esfriar a temperatura ambiente a adicionar o $\mathrm{Mg}^{2+} 2 \mathrm{M}$ e a glicose $2 \mathrm{M}$. Completar o volume para $100 \mathrm{~mL}$ com água ultrapura. $\mathrm{O}$ pH final deverá estar a 7,0.

Solução estoque de $\mathrm{Mg}^{2+}$ 2M: 20,33 g de $\mathrm{MgCl}_{2}+6 \mathrm{H}_{2} \mathrm{O}, 24,65 \mathrm{~g} \mathrm{MgSO}+7 \mathrm{H}_{2} \mathrm{O}$. Adicionar $100 \mathrm{~mL}$ de água ultrapura e esterilizar por filtração.

Solução estoque de glicose 2M: 360,32 g de glicose em $100 \mathrm{~mL}$ de água ultrapura. Esterilizar por filtração. 
ANEXO B - Valores dos parâmetros físico-químicos medidos no Canal de São Sebastião.

\begin{tabular}{|c|c|c|c|c|c|c|c|c|c|c|c|c|c|}
\hline Data & Hora & $\begin{array}{c}\text { T. mar } \\
\left({ }^{\circ} \mathbf{C}\right)\end{array}$ & $\begin{array}{c}\text { Sal. } \\
(\mathbf{p p m})\end{array}$ & $\begin{array}{c}\text { Cond. } \\
(\mathrm{mS})\end{array}$ & pH & OD & $\begin{array}{c}\text { T. máx. } \\
\left({ }^{\circ} \mathbf{C}\right)\end{array}$ & $\begin{array}{c}\text { T. mín. } \\
\left({ }^{\circ} \mathbf{C}\right)\end{array}$ & $\begin{array}{c}\text { Média } \\
\text { T. máx. e } \\
\text { T. mín. }\left({ }^{\circ} \mathbf{C}\right)\end{array}$ & $\begin{array}{l}\text { Umidade } \\
(\%)\end{array}$ & Corrente & Vento & Céu \\
\hline 22/ago/05 & 08:40 & 23,1 & 34 & 49,4 & 8,22 & 6,16 & 23 & 21 & 22 & 86 & leste F0 & leste & claro \\
\hline $19 /$ set/05 & $08: 55$ & 21,5 & 35 & 44,6 & 8,11 & 7,08 & 22 & 20 & 21 & 90 & leste F1 & leste & nublado \\
\hline 17/out/05 & 08:40 & 23,4 & 34 & 46,1 & 8,10 & 6,19 & 24 & 22 & 23 & 92 & sul F0 & sul & claro \\
\hline 16/nov/05 & $08: 45$ & 24,5 & 34 & 44,2 & 8,36 & 6,31 & 26 & 24 & 25 & 91 & leste F0 & leste & claro \\
\hline 05/dez/05 & $08: 30$ & 23,6 & 34 & 44,3 & 8,29 & 6,11 & 26 & 24 & 25 & 85 & leste F0 & leste & claro \\
\hline 24/jan/06 & $08: 35$ & 26,3 & 34 & 49,3 & 8,25 & 5,22 & 28 & 26 & 27 & 79 & sul F0 & sul & parc.nublado \\
\hline 13/fev/06 & 08:30 & 25,2 & 34 & 44,7 & 8,19 & 6,10 & 26 & 24 & 25 & 88 & sul F0 & leste & nublado \\
\hline 21/mar/06 & $08: 15$ & 25,7 & 34 & 44,6 & 8,29 & 6,40 & 27 & 26 & 26,5 & 87 & sul F0 & sul & claro \\
\hline 25/abr/06 & 08:00 & 25,3 & 34 & 45,3 & 8,15 & 6,28 & 27 & 23 & 25 & 81 & leste F0 & leste & claro \\
\hline 30/mai/06 & 08:05 & 23,3 & 34 & 42,6 & 8,37 & 6,02 & 22 & 20 & 21 & 86 & norte & norte & claro \\
\hline 21/jun/06 & 08:05 & 22,6 & 34 & 42,7 & 8,28 & 5,81 & 22 & 21 & 21,5 & 62 & leste F0 & leste & claro \\
\hline 18/jul/06 & 09:20 & 22,2 & 34 & 39,7 & 8,38 & 6,35 & 21 & 20 & 20,5 & 83 & leste F0 & leste & claro \\
\hline 22/ago/06 & $08: 35$ & 22,1 & 34 & 44,8 & 8,25 & 6,12 & 22 & 18 & 20 & 75 & sul F1 & sul & claro \\
\hline $19 /$ set/06 & $08: 10$ & 22,3 & 34 & 44,2 & 8,35 & 5,81 & 26 & 21 & 23,5 & 90 & leste F0 & leste & nublado \\
\hline 24/out/06 & 08:10 & 22,7 & 34 & 41,9 & 8,43 & 5,68 & 23 & 20 & 21,5 & 73 & leste F0 & leste & claro \\
\hline 21/nov/06 & $08: 20$ & 24,1 & 34 & 43,5 & 8,22 & 5,69 & 26 & 22 & 24 & 96 & sul F2 & sul & nublado \\
\hline 14/dez/06 & $08: 25$ & 23,9 & 34 & 37,6 & 8,20 & 5,50 & 26 & 23 & 24,5 & $\mathrm{NM}$ & leste F0 & leste & nublado \\
\hline 23/jan/07 & 08:00 & 25,7 & 34 & 43,3 & 8,61 & 6,52 & 26 & 24 & 25 & 87 & sul F0 & sul & nublado \\
\hline 13/fev/07 & 08:30 & 25,5 & 35 & 44,2 & 8,37 & 6,31 & 27 & 25 & 26 & 86 & leste F0 & leste & parc.nublado \\
\hline $15 / \mathrm{mar} / 07$ & $08: 35$ & 25,7 & 35 & 44,9 & 8,45 & 6,00 & 28 & 27 & 27,5 & 78 & leste F0 & leste & claro \\
\hline
\end{tabular}

Legenda: Data / Hora - data e horário em que os parâmetros foram medidos; T. mar - temperatura da água do mar; Sal. - salinidade; Cond. - condutividade; OD - oxigênio dissolvido; T. máx. - temperatura máxima do dia; T. mín. - temperatura mínima do dia; Média T. máx. e T. mín. - média dos valores das temperaturas máxima e mínima; NM - valor não medido. 
ANEXO C - Relação dos 168 isolados de bactérias marinhas que tiveram suas regiões 16S rRNA parcialmente seqüenciadas, com seus respectivos resultados.

\begin{tabular}{|c|c|c|c|c|c|c|c|c|c|}
\hline $\mathbf{N}^{0}$ do isolado & $\begin{array}{l}\mathbf{N}^{0} \text { de } \\
\text { acesso * }\end{array}$ & $\begin{array}{l}\text { Data de } \\
\text { acesso ** }\end{array}$ & Classe & Ordem & Família & Gênero & Linhagem tipo mais próxima & $\underset{* * *}{\text { Similaridade }}$ & $\begin{array}{c}\mathbf{N}^{0} \text { de par } \\
\text { de bases } \\
* * * * *\end{array}$ \\
\hline BMV1-SS & AJ630103 & $15 / 06 / 2009$ & Gammaproteobacteria & Vibrionales & Vibrionaceae & Vibrio & Vibrio ponticus (T); CECT 5869 & 99,6 & 602 \\
\hline BMV2-SS & AB032015 & $15 / 06 / 2009$ & Gammaproteobacteria & Vibrionales & Vibrionaceae & Photobacterium & $\begin{array}{l}\text { Photobacterium damselae subsp. damselae } \\
\text { (T); ATCC } 33539\end{array}$ & 99,8 & 602 \\
\hline BMV3-SS & AJ630103 & $15 / 06 / 2009$ & Gammaproteobacteria & Vibrionales & Vibrionaceae & Vibrio & Vibrio ponticus (T); CECT 5869 & 99,6 & 602 \\
\hline BMV4-SS & AJ630103 & $15 / 06 / 2009$ & Gammaproteobacteria & Vibrionales & Vibrionaceae & Vibrio & Vibrio ponticus (T); CECT 5869 & 99,6 & 602 \\
\hline BMV5-SS & AJ316199 & $15 / 06 / 2009$ & Gammaproteobacteria & Vibrionales & Vibrionaceae & Vibrio & Vibrio chagasii $(\mathrm{T}) ; \mathrm{R}-3712$ & 99,6 & 606 \\
\hline BMV6-SS & AJ630103 & $15 / 06 / 2009$ & Gammaproteobacteria & Vibrionales & Vibrionaceae & Vibrio & Vibrio ponticus (T); CECT 5869 & 99,6 & 602 \\
\hline BMV7-SS & M22508 & $15 / 06 / 2009$ & Betaproteobacteria & Burkholderiales & Alcaligenaceae & Alcaligenes & Alcaligenes faecalis subsp. faecalis (T) & 98,2 & 591 \\
\hline BMV8-SS & AJ630103 & $15 / 06 / 2009$ & Gammaproteobacteria & Vibrionales & Vibrionaceae & Vibrio & Vibrio ponticus (T); СЕCT 5869 & 99,6 & 602 \\
\hline BMV9-SS & AJ630103 & $15 / 06 / 2009$ & Gammaproteobacteria & Vibrionales & Vibrionaceae & Vibrio & Vibrio ponticus (T); СЕCT 5869 & 99,6 & 602 \\
\hline BMV10-SS & AJ316199 & $15 / 06 / 2009$ & Gammaproteobacteria & Vibrionales & Vibrionaceae & Vibrio & Vibrio chagasii (T); R-3712 & 99,6 & 606 \\
\hline BMV11-SS & AJ316199 & $15 / 06 / 2009$ & Gammaproteobacteria & Vibrionales & Vibrionaceae & Vibrio & Vibrio chagasii $(\mathrm{T}) ; \mathrm{R}-3712$ & 99,6 & 606 \\
\hline BMV12-SS & AJ316199 & $15 / 06 / 2009$ & Gammaproteobacteria & Vibrionales & Vibrionaceae & Vibrio & Vibrio chagasii (T); R-3712 & 99,6 & 606 \\
\hline BMV13-SS & AB013297 & $15 / 06 / 2009$ & Gammaproteobacteria & Vibrionales & Vibrionaceae & Vibrio & Vibrio rumoiensis (T); S-1 & 99,2 & 599 \\
\hline BMV14-SS & AF072688 & $15 / 06 / 2009$ & Gammaproteobacteria & Pseudomonadales & Pseudomonadaceae & Pseudomonas & Pseudomonas mosselii (T); CIP 105259 & 99,8 & 602 \\
\hline BMV15-SS & AF072688 & $15 / 06 / 2009$ & Gammaproteobacteria & Pseudomonadales & Pseudomonadaceae & Pseudomonas & Pseudomonas mosselii (T); CIP 105259 & 99,8 & 602 \\
\hline BMV17-SS & AJ630103 & $15 / 06 / 2009$ & Gammaproteobacteria & Vibrionales & Vibrionaceae & Vibrio & Vibrio ponticus (T); CECT 5869 & 99,6 & 602 \\
\hline BMV18-SS & AJ630103 & $15 / 06 / 2009$ & Gammaproteobacteria & Vibrionales & Vibrionaceae & Vibrio & Vibrio ponticus (T); CECT 5869 & 99,6 & 602 \\
\hline BMV21-SS & AJ630103 & $15 / 06 / 2009$ & Gammaproteobacteria & Vibrionales & Vibrionaceae & Vibrio & Vibrio ponticus (T); CECT 5869 & 99,6 & 602 \\
\hline BMV22-SS & AJ630103 & $15 / 06 / 2009$ & Gammaproteobacteria & Vibrionales & Vibrionaceae & Vibrio & Vibrio ponticus (T); CECT 5869 & 99,6 & 602 \\
\hline BMV23-SS & AJ630103 & $15 / 06 / 2009$ & Gammaproteobacteria & Vibrionales & Vibrionaceae & Vibrio & Vibrio ponticus (T); CECT 5869 & 99,6 & 602 \\
\hline BMV25-SS & $\mathrm{X} 60415$ & $15 / 06 / 2009$ & Gammaproteobacteria & Aeromonadales & Aeromonadaceae & Aeromonas & $\begin{array}{l}\text { Aeromonas enteropelogenes (T); ATCC } \\
49657\end{array}$ & 100 & 600 \\
\hline BMV26-SS & AJ630103 & $15 / 06 / 2009$ & Gammaproteobacteria & Vibrionales & Vibrionaceae & Vibrio & Vibrio ponticus (T); CECT 5869 & 99,6 & 602 \\
\hline BMV27-SS & AJ630103 & $15 / 06 / 2009$ & Gammaproteobacteria & Vibrionales & Vibrionaceae & Vibrio & Vibrio ponticus (T); СЕCT 5869 & 99,6 & 602 \\
\hline BMV28-SS & AJ630103 & $15 / 06 / 2009$ & Gammaproteobacteria & Vibrionales & Vibrionaceae & Vibrio & Vibrio ponticus (T); CECT 5869 & 99,6 & 602 \\
\hline BMV30-SS & AJ316199 & $15 / 06 / 2009$ & Gammaproteobacteria & Vibrionales & Vibrionaceae & Vibrio & Vibrio chagasii (T); R-3712 & 99,6 & 606 \\
\hline BMV31-SS & AJ630103 & $15 / 06 / 2009$ & Gammaproteobacteria & Vibrionales & Vibrionaceae & Vibrio & Vibrio ponticus (T); CECT 5869 & 99,6 & 602 \\
\hline BMV33-SS & AJ630103 & $15 / 06 / 2009$ & Gammaproteobacteria & Vibrionales & Vibrionaceae & Vibrio & Vibrio ponticus (T); CECT 5869 & 99,6 & 602 \\
\hline
\end{tabular}




\begin{tabular}{|c|c|c|c|c|c|c|c|c|c|}
\hline $\mathrm{N}^{0}$ do isolado & $\begin{array}{c}\mathbf{N}^{0} \text { de } \\
\text { acesso * }\end{array}$ & $\begin{array}{l}\text { Data de } \\
\text { acesso ** }\end{array}$ & Classe & Ordem & Família & Gênero & Linhagem tipo mais próxima & $\underset{* * *}{\text { Similaridade }}$ & $\begin{array}{c}\mathbf{N}^{0} \text { de par } \\
\text { de bases } \\
* * * * * *\end{array}$ \\
\hline BMV35-SS & AJ630103 & $15 / 06 / 2009$ & Gammaproteobacteria & Vibrionales & Vibrionaceae & Vibrio & Vibrio ponticus (T); CECT 5869 & 99,6 & 602 \\
\hline BMV36-SS & AJ630103 & $15 / 06 / 2009$ & Gammaproteobacteria & Vibrionales & Vibrionaceae & Vibrio & Vibrio ponticus (T); СЕCT 5869 & 99,6 & 602 \\
\hline BMV37-SS & AJ630103 & $15 / 06 / 2009$ & Gammaproteobacteria & Vibrionales & Vibrionaceae & Vibrio & Vibrio ponticus (T); СЕCT 5869 & 99,6 & 602 \\
\hline BMV38-SS & AJ630103 & $15 / 06 / 2009$ & Gammaproteobacteria & Vibrionales & Vibrionaceae & Vibrio & Vibrio ponticus (T); СЕСТ 5869 & 99,6 & 602 \\
\hline BMV39-SS & AJ316199 & $15 / 06 / 2009$ & Gammaproteobacteria & Vibrionales & Vibrionaceae & Vibrio & Vibrio chagasii $(\mathrm{T}) ; \mathrm{R}-3712$ & 99,6 & 606 \\
\hline BMV40-SS & AJ630103 & $15 / 06 / 2009$ & Gammaproteobacteria & Vibrionales & Vibrionaceae & Vibrio & Vibrio ponticus (T); СЕСТ 5869 & 99,6 & 602 \\
\hline BMV41-SS & AJ630103 & $15 / 06 / 2009$ & Gammaproteobacteria & Vibrionales & Vibrionaceae & Vibrio & Vibrio ponticus (T); СЕCT 5869 & 99,6 & 602 \\
\hline BMV42-SS & AJ630103 & $15 / 06 / 2009$ & Gammaproteobacteria & Vibrionales & Vibrionaceae & Vibrio & Vibrio ponticus (T); СЕCT 5869 & 99,6 & 602 \\
\hline BMV43-SS & AJ630103 & $15 / 06 / 2009$ & Gammaproteobacteria & Vibrionales & Vibrionaceae & Vibrio & Vibrio ponticus (T); СЕCT 5869 & 99,6 & 602 \\
\hline BMV44-SS & AJ630103 & $15 / 06 / 2009$ & Gammaproteobacteria & Vibrionales & Vibrionaceae & Vibrio & Vibrio ponticus (T); СЕСТ 5869 & 99,6 & 602 \\
\hline BMV45-SS & AJ630103 & $15 / 06 / 2009$ & Gammaproteobacteria & Vibrionales & Vibrionaceae & Vibrio & Vibrio ponticus (T); СЕCT 5869 & 99,6 & 602 \\
\hline BMV46-SS & AJ316199 & $15 / 06 / 2009$ & Gammaproteobacteria & Vibrionales & Vibrionaceae & Vibrio & Vibrio chagasii $(\mathrm{T}) ; \mathrm{R}-3712$ & 99,6 & 606 \\
\hline BMV47-SS & AJ630103 & $15 / 06 / 2009$ & Gammaproteobacteria & Vibrionales & Vibrionaceae & Vibrio & Vibrio ponticus (T); СЕСТ 5869 & 99,6 & 602 \\
\hline BMV48-SS & AJ630103 & $15 / 06 / 2009$ & Gammaproteobacteria & Vibrionales & Vibrionaceae & Vibrio & Vibrio ponticus (T); СЕСТ 5869 & 99,6 & 602 \\
\hline BMV56-SS & AJ630103 & $15 / 06 / 2009$ & Gammaproteobacteria & Vibrionales & Vibrionaceae & Vibrio & Vibrio ponticus (T); CECT 5869 & 99,6 & 602 \\
\hline BMV57-SS & AJ877265 & $15 / 06 / 2009$ & Alphaproteobacteria & Rhodobacterales & Rhodobacteraceae & Yangia & Yangia pacifica $(\mathrm{T})$; type strain: DX5-10 & 98,4 & 579 \\
\hline BMV59-SS & AJ630103 & $15 / 06 / 2009$ & Gammaproteobacteria & Vibrionales & Vibrionaceae & Vibrio & Vibrio ponticus (T); СЕCT 5869 & 99,6 & 602 \\
\hline BMV64-SS & AJ630103 & $15 / 06 / 2009$ & Gammaproteobacteria & Vibrionales & Vibrionaceae & Vibrio & Vibrio ponticus (T); СЕCT 5869 & 99,6 & 602 \\
\hline BMV68-SS & AJ630103 & $15 / 06 / 2009$ & Gammaproteobacteria & Vibrionales & Vibrionaceae & Vibrio & Vibrio ponticus (T); СЕCT 5869 & 99,6 & 602 \\
\hline BMV71-SS & AJ878874 & $15 / 06 / 2009$ & Alphaproteobacteria & Rhodobacterales & Rhodobacteraceae & Thalassobius & $\begin{array}{l}\text { Thalassobius mediterraneus (T); CECT } \\
5383\end{array}$ & 99,6 & 578 \\
\hline BMV74-SS & AJ877265 & $15 / 06 / 2009$ & Alphaproteobacteria & Rhodobacterales & Rhodobacteraceae & Yangia & Yangia pacifica $(\mathrm{T})$; type strain: DX5-10 & 98,4 & 579 \\
\hline BMV76-SS & AJ630103 & $15 / 06 / 2009$ & Gammaproteobacteria & Vibrionales & Vibrionaceae & Vibrio & Vibrio ponticus (T); СЕCT 5869 & 99,6 & 602 \\
\hline BMV77-SS & AJ630103 & $15 / 06 / 2009$ & Gammaproteobacteria & Vibrionales & Vibrionaceae & Vibrio & Vibrio ponticus $(\mathrm{T})$; СЕСТ 5869 & 99,6 & 602 \\
\hline BMV78-SS & AJ630103 & $15 / 06 / 2009$ & Gammaproteobacteria & Vibrionales & Vibrionaceae & Vibrio & Vibrio ponticus $(\mathrm{T})$; СЕСТ 5869 & 99,6 & 602 \\
\hline BMV79-SS & AJ630103 & $15 / 06 / 2009$ & Gammaproteobacteria & Vibrionales & Vibrionaceae & Vibrio & Vibrio ponticus (T); СЕCT 5869 & 99,6 & 602 \\
\hline BMV80-SS & AJ630103 & $15 / 06 / 2009$ & Gammaproteobacteria & Vibrionales & Vibrionaceae & Vibrio & Vibrio ponticus (T); СЕCT 5869 & 99,6 & 602 \\
\hline BMV83-SS & AJ630103 & $15 / 06 / 2009$ & Gammaproteobacteria & Vibrionales & Vibrionaceae & Vibrio & Vibrio ponticus (T); СЕCT 5869 & 99,6 & 602 \\
\hline BMV85-SS & AJ630103 & $15 / 06 / 2009$ & Gammaproteobacteria & Vibrionales & Vibrionaceae & Vibrio & Vibrio ponticus (T); СЕСТ 5869 & 99,6 & 602 \\
\hline BMV87-SS & AJ630103 & $15 / 06 / 2009$ & Gammaproteobacteria & Vibrionales & Vibrionaceae & Vibrio & Vibrio ponticus (T); CECT 5869 & 99,6 & 602 \\
\hline BMV88-SS & AJ630103 & $15 / 06 / 2009$ & Gammaproteobacteria & Vibrionales & Vibrionaceae & Vibrio & Vibrio ponticus (T); CECT 5869 & 99,6 & 602 \\
\hline
\end{tabular}




\begin{tabular}{|c|c|c|c|c|c|c|c|c|c|}
\hline $\mathbf{N}^{0}$ do isolado & $\begin{array}{c}\mathbf{N}^{0} \text { de } \\
\text { acesso * }\end{array}$ & $\begin{array}{l}\text { Data de } \\
\text { acesso ** }\end{array}$ & Classe & Ordem & Família & Gênero & Linhagem tipo mais próxima & $\underset{* * *}{\text { Similaridade }}$ & $\begin{array}{c}\mathbf{N}^{0} \text { de par } \\
\text { de bases } \\
* * * * *\end{array}$ \\
\hline BMV89-SS & AJ630103 & $15 / 06 / 2009$ & Gammaproteobacteria & Vibrionales & Vibrionaceae & Vibrio & Vibrio ponticus $(\mathrm{T}) ;$ СЕCT 5869 & 99,6 & 602 \\
\hline BMV90-SS & AJ630103 & $15 / 06 / 2009$ & Gammaproteobacteria & Vibrionales & Vibrionaceae & Vibrio & Vibrio ponticus (T); СЕCT 5869 & 99,6 & 602 \\
\hline BMV91-SS & AJ630103 & $15 / 06 / 2009$ & Gammaproteobacteria & Vibrionales & Vibrionaceae & Vibrio & Vibrio ponticus $(\mathrm{T})$; СЕСТ 5869 & 99,6 & 602 \\
\hline BMV92-SS & AJ630103 & $15 / 06 / 2009$ & Gammaproteobacteria & Vibrionales & Vibrionaceae & Vibrio & Vibrio ponticus $(\mathrm{T})$; СЕСТ 5869 & 99,6 & 602 \\
\hline BMV93-SS & AJ630103 & $15 / 06 / 2009$ & Gammaproteobacteria & Vibrionales & Vibrionaceae & Vibrio & Vibrio ponticus (T); СЕCT 5869 & 99,6 & 602 \\
\hline BMV94-SS & AJ630103 & $15 / 06 / 2009$ & Gammaproteobacteria & Vibrionales & Vibrionaceae & Vibrio & Vibrio ponticus (T); СЕСТ 5869 & 99,6 & 602 \\
\hline BMV95-SS & AJ630103 & $15 / 06 / 2009$ & Gammaproteobacteria & Vibrionales & Vibrionaceae & Vibrio & Vibrio ponticus (T); СЕСТ 5869 & 99,6 & 602 \\
\hline BMV96-SS & AJ630103 & $15 / 06 / 2009$ & Gammaproteobacteria & Vibrionales & Vibrionaceae & Vibrio & Vibrio ponticus (T); СЕСТ 5869 & 99,6 & 602 \\
\hline BMV97-SS & AJ630103 & $15 / 06 / 2009$ & Gammaproteobacteria & Vibrionales & Vibrionaceae & Vibrio & Vibrio ponticus $(\mathrm{T})$; СЕСТ 5869 & 99,6 & 602 \\
\hline BMV98-SS & AJ630103 & $15 / 06 / 2009$ & Gammaproteobacteria & Vibrionales & Vibrionaceae & Vibrio & Vibrio ponticus (T); ЕCT 5869 & 99,6 & 602 \\
\hline BMV99-SS & AJ630103 & $15 / 06 / 2009$ & Gammaproteobacteria & Vibrionales & Vibrionaceae & Vibrio & Vibrio ponticus $(\mathrm{T})$; СЕСТ 5869 & 99,6 & 602 \\
\hline BMV100-SS & AJ630103 & $15 / 06 / 2009$ & Gammaproteobacteria & Vibrionales & Vibrionaceae & Vibrio & Vibrio ponticus (T); СЕСТ 5869 & 99,6 & 602 \\
\hline BMV101-SS & AJ630103 & $15 / 06 / 2009$ & Gammaproteobacteria & Vibrionales & Vibrionaceae & Vibrio & Vibrio ponticus (T); СЕСТ 5869 & 99,6 & 602 \\
\hline BMV102-SS & AJ630103 & $15 / 06 / 2009$ & Gammaproteobacteria & Vibrionales & Vibrionaceae & Vibrio & Vibrio ponticus (T); СЕСТ 5869 & 99,6 & 602 \\
\hline BMV103-SS & AJ630103 & $15 / 06 / 2009$ & Gammaproteobacteria & Vibrionales & Vibrionaceae & Vibrio & Vibrio ponticus $(\mathrm{T})$; СЕCT 5869 & 99,6 & 602 \\
\hline BMV104-SS & AJ630103 & $15 / 06 / 2009$ & Gammaproteobacteria & Vibrionales & Vibrionaceae & Vibrio & Vibrio ponticus $(\mathrm{T})$; СЕСТ 5869 & 99,6 & 602 \\
\hline BMV105-SS & AJ630103 & $15 / 06 / 2009$ & Gammaproteobacteria & Vibrionales & Vibrionaceae & Vibrio & Vibrio ponticus (T); СЕСТ 5869 & 99,6 & 602 \\
\hline BMV106-SS & AJ630103 & $15 / 06 / 2009$ & Gammaproteobacteria & Vibrionales & Vibrionaceae & Vibrio & Vibrio ponticus $(\mathrm{T})$; СЕСТ 5869 & 99,6 & 602 \\
\hline BMV107-SS & AJ630103 & $15 / 06 / 2009$ & Gammaproteobacteria & Vibrionales & Vibrionaceae & Vibrio & Vibrio ponticus $(\mathrm{T})$; СЕСТ 5869 & 99,6 & 602 \\
\hline BMV108-SS & AJ630103 & $15 / 06 / 2009$ & Gammaproteobacteria & Vibrionales & Vibrionaceae & Vibrio & Vibrio ponticus (T); СЕCT 5869 & 99,6 & 602 \\
\hline BMV109-SS & AJ630103 & $15 / 06 / 2009$ & Gammaproteobacteria & Vibrionales & Vibrionaceae & Vibrio & Vibrio ponticus (T); СЕСТ 5869 & 99,6 & 602 \\
\hline BMV112-SS & AJ630103 & $15 / 06 / 2009$ & Gammaproteobacteria & Vibrionales & Vibrionaceae & Vibrio & Vibrio ponticus $(\mathrm{T})$; СЕСТ 5869 & 99,6 & 602 \\
\hline BMV113-SS & AJ630103 & $15 / 06 / 2009$ & Gammaproteobacteria & Vibrionales & Vibrionaceae & Vibrio & Vibrio ponticus (T); СЕCT 5869 & 99,6 & 602 \\
\hline BMV114-SS & AJ630103 & $15 / 06 / 2009$ & Gammaproteobacteria & Vibrionales & Vibrionaceae & Vibrio & Vibrio ponticus (T); СЕСТ 5869 & 99,6 & 602 \\
\hline BMV115-SS & AJ630103 & $15 / 06 / 2009$ & Gammaproteobacteria & Vibrionales & Vibrionaceae & Vibrio & Vibrio ponticus (T); СЕСТ 5869 & 99,6 & 602 \\
\hline BMV119-SS & AJ630103 & $15 / 06 / 2009$ & Gammaproteobacteria & Vibrionales & Vibrionaceae & Vibrio & Vibrio ponticus (T); СЕCT 5869 & 99,6 & 602 \\
\hline BMV126-SS & AJ877265 & $15 / 06 / 2009$ & Alphaproteobacteria & Rhodobacterales & Rhodobacteraceae & Yangia & Yangia pacifica $(\mathrm{T}) ;$ type strain: DX5-10 & 98,4 & 579 \\
\hline BMV129-SS & $\mathrm{Y} 18228$ & $15 / 06 / 2009$ & Gammaproteobacteria & Alteromonadales & Alteromonadaceae & Alteromonas & Alteromonas macleodii (T); DSM 6062 & 98,6 & 601 \\
\hline BMV130-SS & AJ630103 & $15 / 06 / 2009$ & Gammaproteobacteria & Vibrionales & Vibrionaceae & Vibrio & Vibrio ponticus (T); СЕCT 5869 & 99,6 & 602 \\
\hline BMV133-SS & AJ630103 & $15 / 06 / 2009$ & Gammaproteobacteria & Vibrionales & Vibrionaceae & Vibrio & Vibrio ponticus (T); СЕCT 5869 & 99,6 & 602 \\
\hline BMV138-SS & AJ630103 & $15 / 06 / 2009$ & Gammaproteobacteria & Vibrionales & Vibrionaceae & Vibrio & Vibrio ponticus (T); СЕСТ 5869 & 99,6 & 602 \\
\hline
\end{tabular}




\begin{tabular}{|c|c|c|c|c|c|c|c|c|c|}
\hline $\mathrm{N}^{0}$ do isolado & $\begin{array}{c}\mathbf{N}^{0} \mathrm{de} \\
\text { acesso * }\end{array}$ & $\begin{array}{l}\text { Data de } \\
\text { acesso ** }\end{array}$ & Classe & Ordem & Família & Gênero & Linhagem tipo mais próxima & $\underset{* * *}{\text { Similaridade }}$ & $\begin{array}{c}\mathbf{N}^{0} \text { de par } \\
\text { de bases } \\
* * * * *\end{array}$ \\
\hline BMV139-SS & AJ630103 & $15 / 06 / 2009$ & Gammaproteobacteria & Vibrionales & Vibrionaceae & Vibrio & Vibrio ponticus (T); CECT 5869 & 99,6 & 602 \\
\hline BMV140-SS & AJ630103 & $15 / 06 / 2009$ & Gammaproteobacteria & Vibrionales & Vibrionaceae & Vibrio & Vibrio ponticus (T); CECT 5869 & 99,6 & 602 \\
\hline BMV148-SS & AJ630103 & $15 / 06 / 2009$ & Gammaproteobacteria & Vibrionales & Vibrionaceae & Vibrio & Vibrio ponticus (T); СЕCT 5869 & 99,6 & 602 \\
\hline BMV151-SS & AJ316181 & $15 / 06 / 2009$ & Gammaproteobacteria & Vibrionales & Vibrionaceae & Vibrio & Vibrio xuii (T); R-15052 & 98,2 & 592 \\
\hline BMV152-SS & AJ630103 & $15 / 06 / 2009$ & Gammaproteobacteria & Vibrionales & Vibrionaceae & Vibrio & Vibrio ponticus (T); СЕCT 5869 & 99,6 & 602 \\
\hline BMV153-SS & AJ630103 & $15 / 06 / 2009$ & Gammaproteobacteria & Vibrionales & Vibrionaceae & Vibrio & Vibrio ponticus (T); СЕСТ 5869 & 99,6 & 602 \\
\hline BMV157-SS & AJ630103 & $15 / 06 / 2009$ & Gammaproteobacteria & Vibrionales & Vibrionaceae & Vibrio & Vibrio ponticus (T); СЕCT 5869 & 99,6 & 602 \\
\hline BMV158-SS & AJ630103 & $15 / 06 / 2009$ & Gammaproteobacteria & Vibrionales & Vibrionaceae & Vibrio & Vibrio ponticus (T); СЕCT 5869 & 99,6 & 602 \\
\hline BMV162-SS & AJ630103 & $15 / 06 / 2009$ & Gammaproteobacteria & Vibrionales & Vibrionaceae & Vibrio & Vibrio ponticus (T); СЕCT 5869 & 99,6 & 602 \\
\hline BMV163-SS & AJ630103 & $15 / 06 / 2009$ & Gammaproteobacteria & Vibrionales & Vibrionaceae & Vibrio & Vibrio ponticus (T); CЕCT 5869 & 99,6 & 602 \\
\hline BMV164-SS & AJ842346 & $15 / 06 / 2009$ & Gammaproteobacteria & Vibrionales & Vibrionaceae & Photobacterium & $\begin{array}{l}\text { Photobacterium eurosenbergii (T); LMG } \\
22227\end{array}$ & 100 & 597 \\
\hline BMV167-SS & AJ630103 & $15 / 06 / 2009$ & Gammaproteobacteria & Vibrionales & Vibrionaceae & Vibrio & Vibrio ponticus (T); CECT 5869 & 99,6 & 602 \\
\hline BMV168-SS & AJ842346 & $15 / 06 / 2009$ & Gammaproteobacteria & Vibrionales & Vibrionaceae & Photobacterium & $\begin{array}{l}\text { Photobacterium eurosenbergii (T); LMG } \\
22227\end{array}$ & 100 & 597 \\
\hline BMV169-SS & AJ630103 & $15 / 06 / 2009$ & Gammaproteobacteria & Vibrionales & Vibrionaceae & Vibrio & Vibrio ponticus (T); СЕСТ 5869 & 99,6 & 602 \\
\hline BMV170-SS & AJ630103 & $15 / 06 / 2009$ & Gammaproteobacteria & Vibrionales & Vibrionaceae & Vibrio & Vibrio ponticus (T); СЕCT 5869 & 99,6 & 602 \\
\hline BMV171-SS & AF005249 & $15 / 06 / 2009$ & Gammaproteobacteria & Alteromonadales & Shewanellaceae & Shewanella & Shewanella algae (T); ATCC 51192 & 98,8 & 594 \\
\hline BMV173-SS & AJ630103 & $15 / 06 / 2009$ & Gammaproteobacteria & Vibrionales & Vibrionaceae & Vibrio & Vibrio ponticus (T); CECT 5869 & 99,6 & 602 \\
\hline BMV174-SS & AJ316199 & $15 / 06 / 2009$ & Gammaproteobacteria & Vibrionales & Vibrionaceae & Vibrio & Vibrio chagasii $(\mathrm{T}) ; \mathrm{R}-3712$ & 99,6 & 606 \\
\hline BMV177-SS & AJ630103 & $15 / 06 / 2009$ & Gammaproteobacteria & Vibrionales & Vibrionaceae & Vibrio & Vibrio ponticus (T); СЕCT 5869 & 99,6 & 602 \\
\hline BMV181-SS & AJ630103 & $15 / 06 / 2009$ & Gammaproteobacteria & Vibrionales & Vibrionaceae & Vibrio & Vibrio ponticus (T); СЕCT 5869 & 99,6 & 602 \\
\hline BMV186-SS & AJ630103 & $15 / 06 / 2009$ & Gammaproteobacteria & Vibrionales & Vibrionaceae & Vibrio & Vibrio ponticus (T); СЕCT 5869 & 99,6 & 602 \\
\hline BMV198-SS & AJ630103 & $15 / 06 / 2009$ & Gammaproteobacteria & Vibrionales & Vibrionaceae & Vibrio & Vibrio ponticus (T); СЕСТ 5869 & 99,6 & 602 \\
\hline BMV200-SS & AJ440005 & $15 / 06 / 2009$ & Gammaproteobacteria & Vibrionales & Vibrionaceae & Vibrio & Vibrio coralliilyticus (T); LMG 20984 & 97,6 & 596 \\
\hline BMV201-SS & AJ630103 & $15 / 06 / 2009$ & Gammaproteobacteria & Vibrionales & Vibrionaceae & Vibrio & Vibrio ponticus (T); CECT 5869 & 99,6 & 602 \\
\hline BMV202-SS & AJ630103 & $15 / 06 / 2009$ & Gammaproteobacteria & Vibrionales & Vibrionaceae & Vibrio & Vibrio ponticus (T); СЕCT 5869 & 99,6 & 602 \\
\hline BMV203-SS & AJ630103 & $15 / 06 / 2009$ & Gammaproteobacteria & Vibrionales & Vibrionaceae & Vibrio & Vibrio ponticus (T); СЕСТ 5869 & 99,6 & 602 \\
\hline BMV205-SS & AJ630103 & $15 / 06 / 2009$ & Gammaproteobacteria & Vibrionales & Vibrionaceae & Vibrio & Vibrio ponticus (T); СЕCT 5869 & 99,6 & 602 \\
\hline BMV208-SS & AJ630103 & $15 / 06 / 2009$ & Gammaproteobacteria & Vibrionales & Vibrionaceae & Vibrio & Vibrio ponticus (T); СЕCT 5869 & 99,6 & 602 \\
\hline BMV209-SS & AJ630103 & $15 / 06 / 2009$ & Gammaproteobacteria & Vibrionales & Vibrionaceae & Vibrio & Vibrio ponticus (T); CECT 5869 & 99,6 & 602 \\
\hline BMV210-SS & AJ630103 & $15 / 06 / 2009$ & Gammaproteobacteria & Vibrionales & Vibrionaceae & Vibrio & Vibrio ponticus $(\mathrm{T})$; СЕСТ 5869 & 99,6 & 602 \\
\hline
\end{tabular}




\begin{tabular}{|c|c|c|c|c|c|c|c|c|c|}
\hline $\mathbf{N}^{0}$ do isolado & $\begin{array}{l}\mathbf{N}^{0} \text { de } \\
\text { acesso * }\end{array}$ & $\begin{array}{l}\text { Data de } \\
\text { acesso ** }\end{array}$ & Classe & Ordem & Família & Gênero & Linhagem tipo mais próxima & $\underset{* * *}{\text { Similaridade }}$ & $\begin{array}{c}\mathbf{N}^{0} \text { de par } \\
\text { de bases } \\
* * * * *\end{array}$ \\
\hline BMV211-SS & AJ630103 & $15 / 06 / 2009$ & Gammaproteobacteria & Vibrionales & Vibrionaceae & Vibrio & Vibrio ponticus $(\mathrm{T}) ;$ СЕCT 5869 & 99,6 & 602 \\
\hline BMV214-SS & AJ630103 & $15 / 06 / 2009$ & Gammaproteobacteria & Vibrionales & Vibrionaceae & Vibrio & Vibrio ponticus (T); СЕCT 5869 & 99,6 & 602 \\
\hline BMV216-SS & AJ630103 & $15 / 06 / 2009$ & Gammaproteobacteria & Vibrionales & Vibrionaceae & Vibrio & Vibrio ponticus $(\mathrm{T})$; СЕСТ 5869 & 99,6 & 602 \\
\hline BMV217-SS & AJ630103 & $15 / 06 / 2009$ & Gammaproteobacteria & Vibrionales & Vibrionaceae & Vibrio & Vibrio ponticus $(\mathrm{T})$; СЕСТ 5869 & 99,6 & 602 \\
\hline BMV218-SS & AJ630103 & $15 / 06 / 2009$ & Gammaproteobacteria & Vibrionales & Vibrionaceae & Vibrio & Vibrio ponticus (T); СЕCT 5869 & 99,6 & 602 \\
\hline BMV219-SS & AJ630103 & $15 / 06 / 2009$ & Gammaproteobacteria & Vibrionales & Vibrionaceae & Vibrio & Vibrio ponticus (T); СЕСТ 5869 & 99,6 & 602 \\
\hline BMV220-SS & AJ630103 & $15 / 06 / 2009$ & Gammaproteobacteria & Vibrionales & Vibrionaceae & Vibrio & Vibrio ponticus (T); СЕСТ 5869 & 99,6 & 602 \\
\hline BMV223-SS & AJ630103 & $15 / 06 / 2009$ & Gammaproteobacteria & Vibrionales & Vibrionaceae & Vibrio & Vibrio ponticus (T); СЕСТ 5869 & 99,6 & 602 \\
\hline BMV224-SS & AJ630103 & $15 / 06 / 2009$ & Gammaproteobacteria & Vibrionales & Vibrionaceae & Vibrio & Vibrio ponticus $(\mathrm{T})$; СЕСТ 5869 & 99,6 & 602 \\
\hline BMV225-SS & AJ630103 & $15 / 06 / 2009$ & Gammaproteobacteria & Vibrionales & Vibrionaceae & Vibrio & Vibrio ponticus $(\mathrm{T})$; СЕСТ 5869 & 99,6 & 602 \\
\hline BMV228-SS & AJ630103 & $15 / 06 / 2009$ & Gammaproteobacteria & Vibrionales & Vibrionaceae & Vibrio & Vibrio ponticus (T); СЕCT 5869 & 99,6 & 602 \\
\hline BMV231-SS & AJ630103 & $15 / 06 / 2009$ & Gammaproteobacteria & Vibrionales & Vibrionaceae & Vibrio & Vibrio ponticus (T); СЕCT 5869 & 99,6 & 602 \\
\hline BMV234-SS & AF316144 & $15 / 06 / 2009$ & Gammaproteobacteria & Alteromonadales & $\begin{array}{l}\text { Pseudoalteromonadace } \\
\text { ae }\end{array}$ & $\begin{array}{l}\text { Pseudoalteromon } \\
\text { as }\end{array}$ & $\begin{array}{l}\text { Pseudoalteromonas issachenkonii (T); } \\
\text { KMM } 3549\end{array}$ & 98,8 & 596 \\
\hline BMV235-SS & AJ630103 & $15 / 06 / 2009$ & Gammaproteobacteria & Vibrionales & Vibrionaceae & Vibrio & Vibrio ponticus (T); CECT 5869 & 99,6 & 602 \\
\hline BMV236-SS & AJ630103 & $15 / 06 / 2009$ & Gammaproteobacteria & Vibrionales & Vibrionaceae & Vibrio & Vibrio ponticus (T); СЕCT 5869 & 99,6 & 602 \\
\hline BMV237-SS & AJ630103 & $15 / 06 / 2009$ & Gammaproteobacteria & Vibrionales & Vibrionaceae & Vibrio & Vibrio ponticus (T); СЕСТ 5869 & 99,6 & 602 \\
\hline BMV240-SS & AJ630103 & $15 / 06 / 2009$ & Gammaproteobacteria & Vibrionales & Vibrionaceae & Vibrio & Vibrio ponticus (T); СЕCT 5869 & 99,6 & 602 \\
\hline BMV241-SS & AJ630103 & $15 / 06 / 2009$ & Gammaproteobacteria & Vibrionales & Vibrionaceae & Vibrio & Vibrio ponticus (T); СЕCT 5869 & 99,6 & 602 \\
\hline BMV242-SS & AJ630103 & $15 / 06 / 2009$ & Gammaproteobacteria & Vibrionales & Vibrionaceae & Vibrio & Vibrio ponticus (T); СЕCT 5869 & 99,6 & 602 \\
\hline BMV245-SS & AJ630103 & $15 / 06 / 2009$ & Gammaproteobacteria & Vibrionales & Vibrionaceae & Vibrio & Vibrio ponticus (T); СЕСТ 5869 & 99,6 & 602 \\
\hline BMV246-SS & AJ630103 & $15 / 06 / 2009$ & Gammaproteobacteria & Vibrionales & Vibrionaceae & Vibrio & Vibrio ponticus (T); СЕCT 5869 & 99,6 & 602 \\
\hline BMV249-SS & AJ630103 & $15 / 06 / 2009$ & Gammaproteobacteria & Vibrionales & Vibrionaceae & Vibrio & Vibrio ponticus (T); СЕСТ 5869 & 99,6 & 602 \\
\hline BMV252-SS & AJ630103 & $15 / 06 / 2009$ & Gammaproteobacteria & Vibrionales & Vibrionaceae & Vibrio & Vibrio ponticus (T); СЕCT 5869 & 99,6 & 602 \\
\hline BMV253-SS & AY189743 & $15 / 06 / 2009$ & Alphaproteobacteria & Rhodobacterales & Rhodobacteraceae & Paracoccus & Paracoccus haeundaensis (T); BC74171 & 92,9 & 578 \\
\hline BMV254-SS & AJ630103 & $15 / 06 / 2009$ & Gammaproteobacteria & Vibrionales & Vibrionaceae & Vibrio & Vibrio ponticus (T); CECT 5869 & 99,6 & 602 \\
\hline BMV255-SS & AJ842346 & $15 / 06 / 2009$ & Gammaproteobacteria & Vibrionales & Vibrionaceae & Photobacterium & $\begin{array}{l}\text { Photobacterium eurosenbergii (T); LMG } \\
22227\end{array}$ & 100 & 597 \\
\hline BMV257-SS & AF072688 & $15 / 06 / 2009$ & Gammaproteobacteria & Pseudomonadales & Pseudomonadaceae & Pseudomonas & Pseudomonas mosselii (T); CIP 105259 & 99,8 & 602 \\
\hline BMV258-SS & AF072688 & $15 / 06 / 2009$ & Gammaproteobacteria & Pseudomonadales & Pseudomonadaceae & Pseudomonas & Pseudomonas mosselii (T); CIP 105259 & 99,8 & 602 \\
\hline BMV259-SS & AJ842346 & $15 / 06 / 2009$ & Gammaproteobacteria & Vibrionales & Vibrionaceae & Photobacterium & $\begin{array}{l}\text { Photobacterium eurosenbergii (T); LMG } \\
22227\end{array}$ & 100 & 597 \\
\hline
\end{tabular}




\begin{tabular}{|c|c|c|c|c|c|c|c|c|c|}
\hline $\mathbf{N}^{0}$ do isolado & $\begin{array}{c}\mathbf{N}^{0} \mathbf{d e} \\
\text { acesso * }\end{array}$ & $\begin{array}{l}\text { Data de } \\
\text { acesso ** }\end{array}$ & Classe & Ordem & Família & Gênero & Linhagem tipo mais próxima & $\underset{* * *}{\text { Similaridade }}$ & $\begin{array}{c}\mathbf{N}^{0} \text { de par } \\
\text { de bases } \\
* * * * *\end{array}$ \\
\hline BMV260-SS & AJ630103 & $15 / 06 / 2009$ & Gammaproteobacteria & Vibrionales & Vibrionaceae & Vibrio & Vibrio ponticus (T); СЕCT 5869 & 99,6 & 602 \\
\hline BMV263-SS & AF529060 & $15 / 06 / 2009$ & Gammaproteobacteria & Alteromonadales & Alteromonadaceae & Alteromonas & Alteromonas marina $(\mathrm{T}) ; \mathrm{SW}-47$ & 99,2 & 600 \\
\hline BMV265-SS & AJ316171 & $15 / 06 / 2009$ & Gammaproteobacteria & Vibrionales & Vibrionaceae & Vibrio & Vibrio neptunius (T); LMG 20536 & 99,2 & 592 \\
\hline BMV269-SS & AJ630103 & $15 / 06 / 2009$ & Gammaproteobacteria & Vibrionales & Vibrionaceae & Vibrio & Vibrio ponticus (T); СЕCT 5869 & 99,6 & 602 \\
\hline BMV271-SS & AJ630103 & $15 / 06 / 2009$ & Gammaproteobacteria & Vibrionales & Vibrionaceae & Vibrio & Vibrio ponticus (T); СЕCT 5869 & 99,6 & 602 \\
\hline BMV273-SS & AJ630103 & $15 / 06 / 2009$ & Gammaproteobacteria & Vibrionales & Vibrionaceae & Vibrio & Vibrio ponticus (T); СЕСТ 5869 & 99,6 & 602 \\
\hline BMV274-SS & AJ630103 & $15 / 06 / 2009$ & Gammaproteobacteria & Vibrionales & Vibrionaceae & Vibrio & Vibrio ponticus (T); СЕCT 5869 & 99,6 & 602 \\
\hline BMV275-SS & AJ630103 & $15 / 06 / 2009$ & Gammaproteobacteria & Vibrionales & Vibrionaceae & Vibrio & Vibrio ponticus (T); СЕСТ 5869 & 99,6 & 602 \\
\hline BMV277-SS & AJ630103 & $15 / 06 / 2009$ & Gammaproteobacteria & Vibrionales & Vibrionaceae & Vibrio & Vibrio ponticus (T); СЕCT 5869 & 99,6 & 602 \\
\hline BMV278-SS & AJ630103 & $15 / 06 / 2009$ & Gammaproteobacteria & Vibrionales & Vibrionaceae & Vibrio & Vibrio ponticus (T); СЕCT 5869 & 99,6 & 602 \\
\hline BMV279-SS & AJ630103 & $15 / 06 / 2009$ & Gammaproteobacteria & Vibrionales & Vibrionaceae & Vibrio & Vibrio ponticus (T); СЕCT 5869 & 99,6 & 602 \\
\hline BMV280-SS & AJ630103 & $15 / 06 / 2009$ & Gammaproteobacteria & Vibrionales & Vibrionaceae & Vibrio & Vibrio ponticus (T); СЕCT 5869 & 99,6 & 602 \\
\hline BMV282-SS & AJ630103 & $15 / 06 / 2009$ & Gammaproteobacteria & Vibrionales & Vibrionaceae & Vibrio & Vibrio ponticus (T); СЕCT 5869 & 99,6 & 602 \\
\hline BMV283-SS & AJ630103 & $15 / 06 / 2009$ & Gammaproteobacteria & Vibrionales & Vibrionaceae & Vibrio & Vibrio ponticus (T); СЕCT 5869 & 99,6 & 602 \\
\hline BMV284-SS & AJ630103 & $15 / 06 / 2009$ & Gammaproteobacteria & Vibrionales & Vibrionaceae & Vibrio & Vibrio ponticus (T); СЕCT 5869 & 99,6 & 602 \\
\hline BMV289-SS & AJ630103 & $15 / 06 / 2009$ & Gammaproteobacteria & Vibrionales & Vibrionaceae & Vibrio & Vibrio ponticus (T); CECT 5869 & 99,6 & 602 \\
\hline BMV290-SS & AJ630103 & $15 / 06 / 2009$ & Gammaproteobacteria & Vibrionales & Vibrionaceae & Vibrio & Vibrio ponticus (T); СЕCT 5869 & 99,6 & 602 \\
\hline BMV291-SS & AJ630103 & $15 / 06 / 2009$ & Gammaproteobacteria & Vibrionales & Vibrionaceae & Vibrio & Vibrio ponticus (T); СЕCT 5869 & 99,6 & 602 \\
\hline BMV292-SS & AJ630103 & $15 / 06 / 2009$ & Gammaproteobacteria & Vibrionales & Vibrionaceae & Vibrio & Vibrio ponticus (T); СЕCT 5869 & 99,6 & 602 \\
\hline BMV293-SS & AJ630103 & $15 / 06 / 2009$ & Gammaproteobacteria & Vibrionales & Vibrionaceae & Vibrio & Vibrio ponticus (T); СЕСТ 5869 & 99,6 & 602 \\
\hline BMV294-SS & AJ630103 & $15 / 06 / 2009$ & Gammaproteobacteria & Vibrionales & Vibrionaceae & Vibrio & Vibrio ponticus (T); СЕСТ 5869 & 99,6 & 602 \\
\hline
\end{tabular}

* Número de acesso da linhagem tipo mais próxima.

**Data de acesso às sequiências das linhagens tipos no GenBank.

***Similaridade com a linhagem tipo mais próxima.

****Número de pares de bases das sequiências de Bactérias Marinhas Viáveis (BMV). 